\title{
A Regional Guidebook for Applying the Hydrogeomorphic Approach to Assessing Wetland Functions of Flats Wetlands in the Everglades
}

Chris V. Noble, Rhonda Evans, Marti McGuire,

July 2002 Katherine Trott, Mary Davis, and Ellis J. Clairain, Jr.

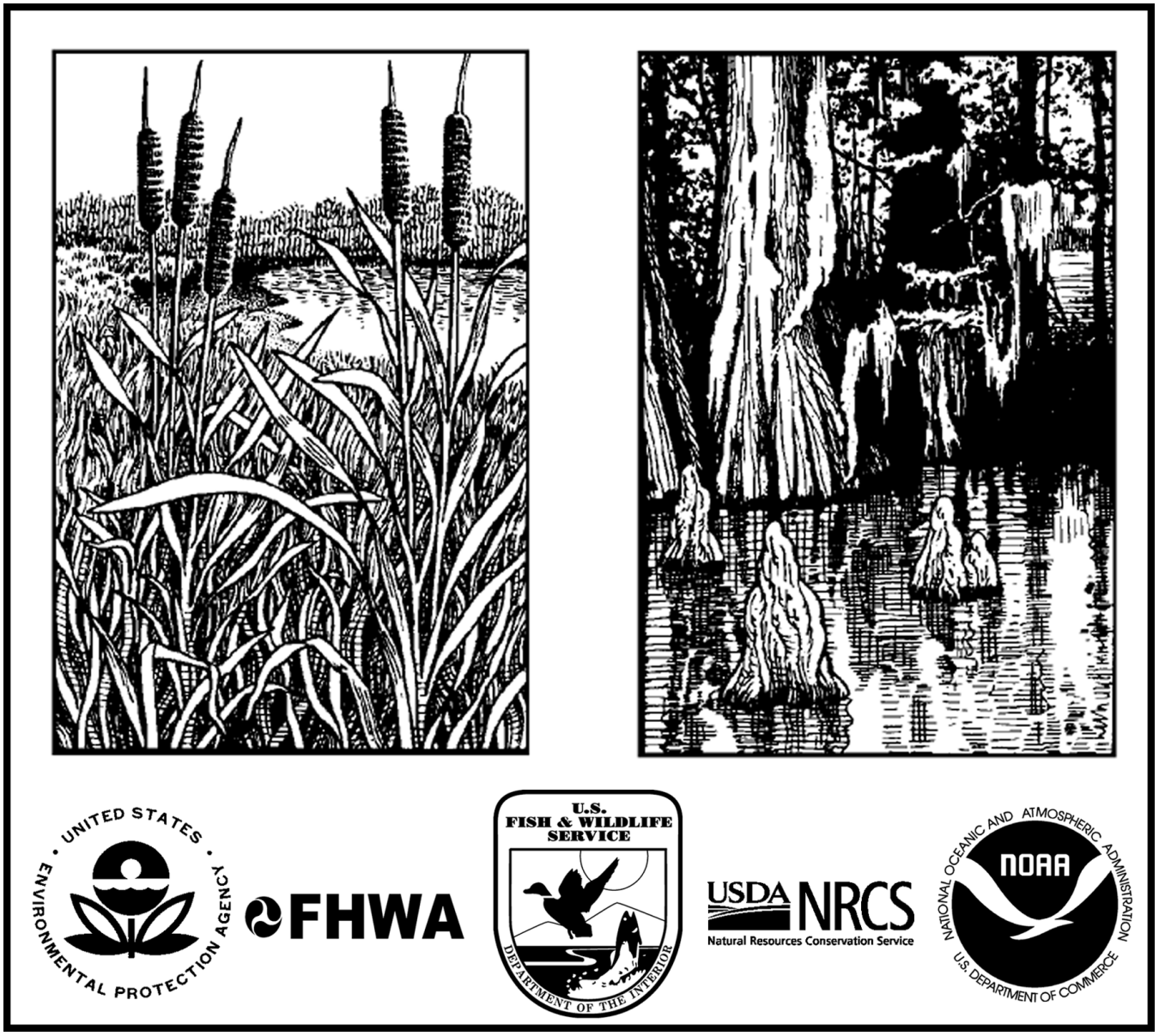


The contents of this report are not to be used for advertising, publication, or promotional purposes. Citation of trade names does not constitute an official endorsement or approval of the use of such commercial products.

The findings of this report are not to be construed as an official Department of the Army position, unless so designated by other authorized documents. 


\title{
A Regional Guidebook for Applying the Hydrogeomorphic Approach to Assessing Wetland Functions of Flats Wetlands in the Everglades
}

\author{
by Chris V. Noble, Ellis J. Clairain, Jr. \\ Environmental Laboratory \\ U.S. Army Engineer Research and Development Center \\ 3909 Halls Ferry Road \\ Vicksburg, MS 39180-6199 \\ Rhonda Evans \\ U.S. Environmental Protection Agency \\ Sam Nunn Federal Center \\ 61 Forsyth Street, SW \\ Atlanta, GA 30303-8960 \\ Marti McGuire \\ Florida Department of Environmental Protection \\ 2600 Blair Stone Road \\ Tallahassee, FL 32399-2400 \\ Katherine Trott \\ Headquarters, U.S. Army Corps of Engineers \\ $441 \mathrm{G}$ St. NW \\ Washington, DC 20314-1000 \\ Mary Davis \\ National Wildlife Federation \\ 1313 West Peachtree \\ Atlanta, GA 30309
}

Final report

Approved for public release; distribution is unlimited 


\title{
Assessing Wetland Functions
}

\begin{abstract}
A Regional Guidebook for Applying the Hydrogeomorphic Approach to Assessing Wetland Functions of Flats Wetlands in the Everglades (ERDC/EL TR-02-19)
\end{abstract}

ISSUE: Section 404 of the Clean Water Act directs the U.S. Army Corps of Engineers to administer a regulatory program for permitting the discharge of dredged or fill material in "waters of the United States." As part of the permit review process, the impact of discharging dredged or fill material on wetland functions must be assessed. On 16 August 1996 a National Action Plan to Implement the Hydrogeomorphic Approach (NAP) for developing Regional Guidebooks to assess wetland functions was published.

RESEARCH OBJECTIVE: The objective of this research was to develop a Regional Guidebook for applying the Hydrogeomorphic Approach to flats wetlands in the Everglades in the context of the 404 Regulatory Program.

SUMMARY: The Hydrogeomorphic (HGM) Approach is a collection of concepts and methods for developing functional indices and subsequently using them to assess the capacity of a wetland to perform functions relative to similar wetlands in a region. The Approach was initially designed to be used in the context of the Clean Water Act Section 404 Regulatory Program permit review sequence to consider alternatives, minimize impacts, assess unavoidable project impacts, determine mitigation requirements, and monitor the success of mitigation projects. However, a variety of other potential applications for the Approach have been identified, including: determining minimal effects under the Food Security Act, designing mitigation projects, and managing wetlands.

AVAILABILITY OF REPORT: The report is available at the following Web sites: http://www.wes.army.mil/el/wetlands/wlpubs. html or http://libweb.wes.army.mil/index.htm. The report is also available on Interlibrary Loan Service from the U.S. Army Engineer Research and Development Center (ERDC) http://libweb. wes.army.mil/lib/library.htm.

About the Authors: Mr. Chris V. Noble is a Soils Scientist, and Dr. Ellis J. Clarain, Jr., is a Research Biologist in the Environmental Laboratory, U.S. Army Engineer Research and Development Center (ERDC). Ms. Rhonda Evans is a Wetland Specialist in the Environmental Protection Agency.

Ms. Marti McGuire is an Environmental Scientist in the Florida Department of Natural Resources. Ms. Katherine Trott is a Senior Project Manager in the Headquarters, U.S. Army Corps of Engineers. Dr. Mary Davis is a Wetland Ecologist in the National Wildlife Federation. Point of Contact at ERDC is Mr. Noble at 601-634-3482, or Dr. Russell F. Theriot, 601-634-2733, Director, Wetlands Research and Technology Center. 


\section{Contents}

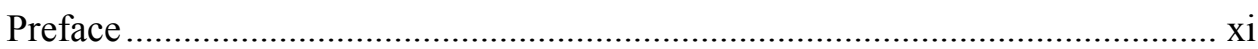

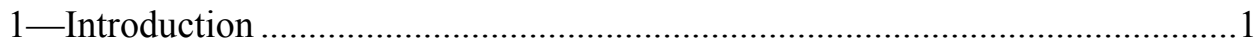

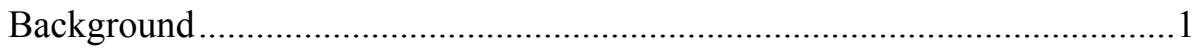

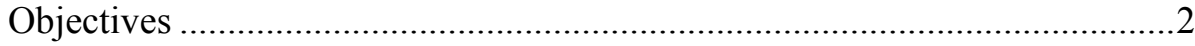

Scope

2-Overview of the Hydrogeomorphic Approach ...............................................

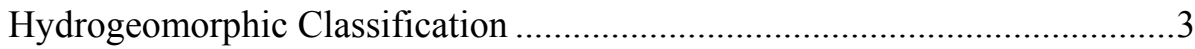

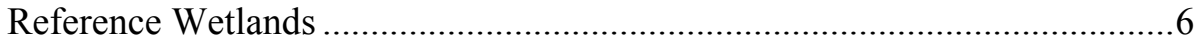

Assessment Models and Functional Indices ...............................................6

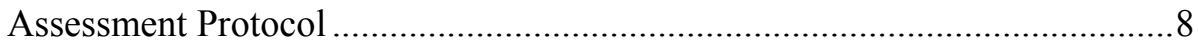

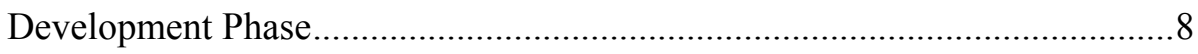

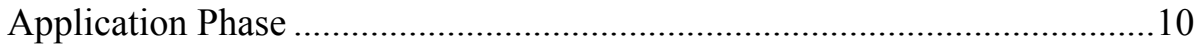

3 - Characterization of Marl, Rocky, and Organic Flats Wetlands of the

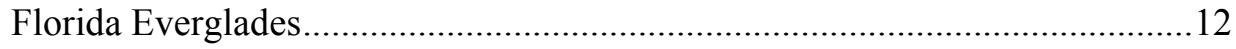

Regional Wetland Subclasses and Reference Domain.................................12

Description of the Regional Wetland Subclasses ..........................................13

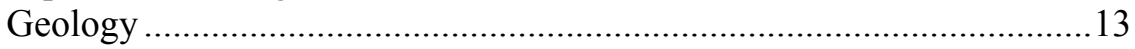

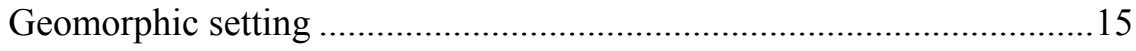

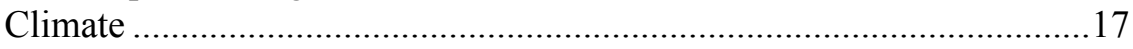

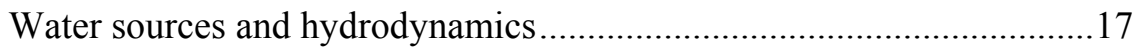

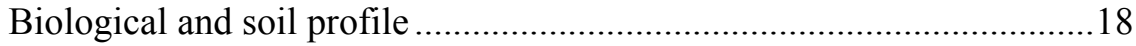

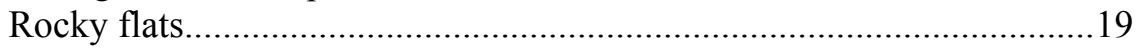

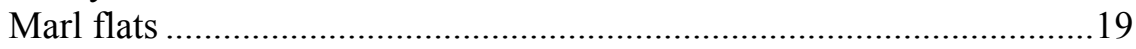

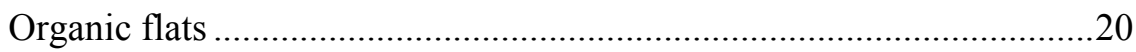

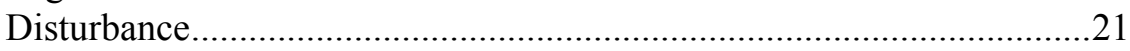

4-Wetland Functions and Assessment Models ............................................26

Function 1: Surface and Subsurface Water Storage.....................................27

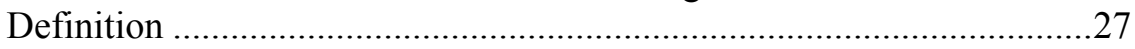

Rationale for selecting the function......................................................27

Characteristics and processes that influence the function ......................27 


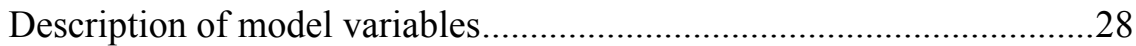

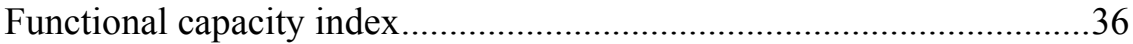

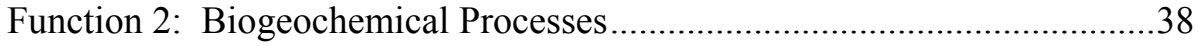

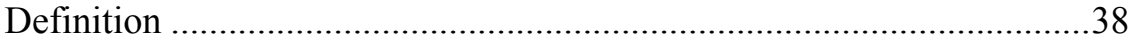

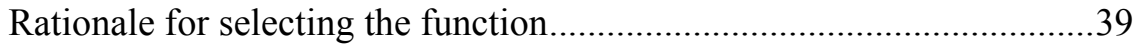

Characteristics and processes that influence the function .......................39

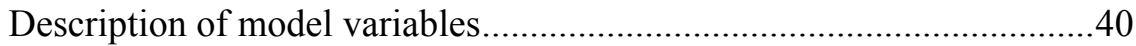

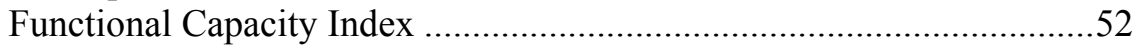

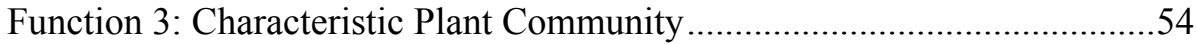

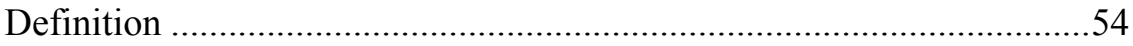

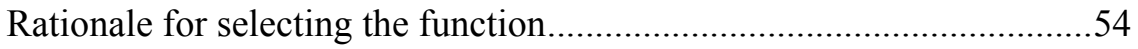

Characteristics and processes that influence the function .......................54

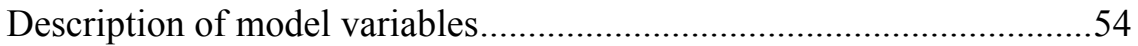

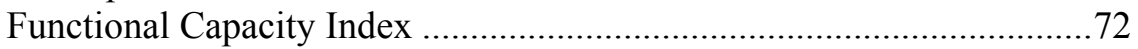

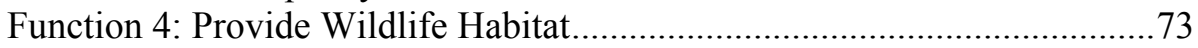

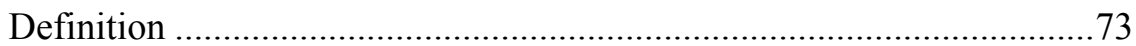

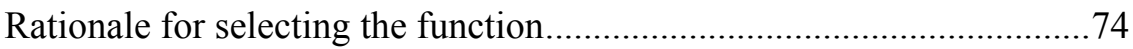

Characteristics and processes that influence the function .......................74

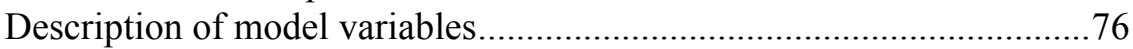

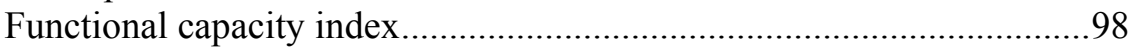

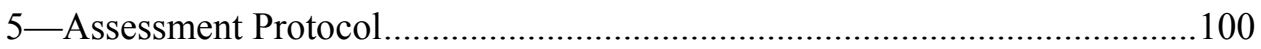

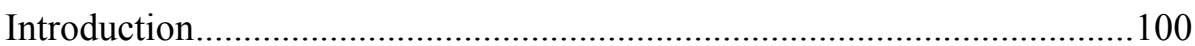

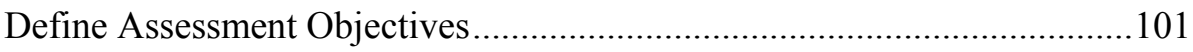

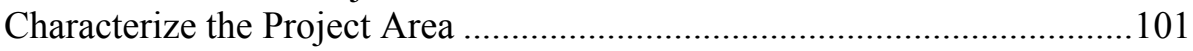

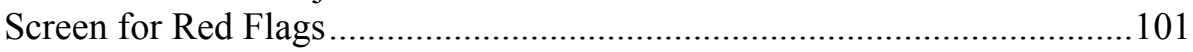

Define the Wetland Assessment Area..........................................................102

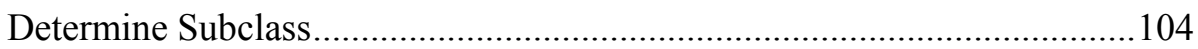

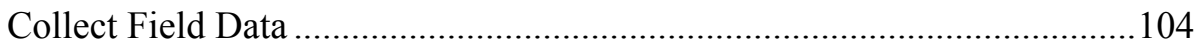

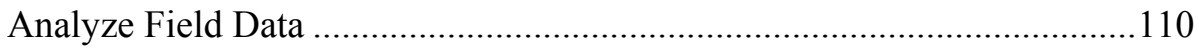

Apply Assessment Results .................................................................... 111

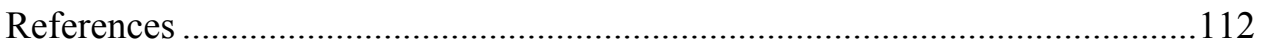

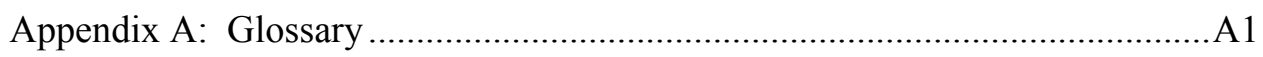

Appendix B: Summaries and Forms for Field Use....................................... B1

Appendix C: Supplementary Information on Model Variables.......................... 1

Appendix D: Reference Wetland Data .......................................................... 1

SF 298 


\section{List of Figures}

Figure 1. Development and application phases of the HGM Approach...........9

Figure 2. Reference domain for the Rocky, Marl, and Organic Flats Everglades wetlands, which corresponds to the historic freshwater Everglades 14

Figure 3. General direction of surface water flow in south Florida including the Everglades. 16

Figure 4. Alteration of the natural surface water flow through the Everglades by a network of canals 22

Figure 5. A very gravelly silt loam soil texture created by rock plowing on this Rocky Flats Everglades site

Figure 6. Relationship between soil thickness and functional capacity .........31

Figure 7. Microtopography altered by bedding for nursery stock.................33

Figure 8. Relationship between woody vegetation and functional capacity ..33

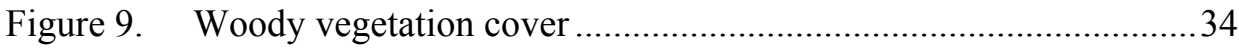

Figure 10. Relationship between periphyton and functional capacity for Rocky Flats Everglades wetlands .................................................35

Figure 11. Relationship between periphyton and functional capacity for Marl Flats Everglades wetlands

Figure 12. Periphyton, found on all reference standard sites in the Rocky and Marl Flats Everglades wetlands

Figure 13. Limestone gravel used as fill material ..........................................41

Figure 14. Natural microtopography destroyed by rock plowing

Figure 15. Relationship between macrophytic vegetation and functional capacity for Rocky Flats Everglades wetlands 44

Figure 16. Relationship between macrophytic vegetation and functional capacity for Marl Flats Everglades wetlands

Figure 17. Relationship between macrophytic vegetation and functional capacity for Organic Flats Everglades wetlands 
Figure 18. Emergent macrophytic cover in reference standard Rocky Flats Everglades wetland showing 20 to 45 percent cover 46

Figure 19. Relationship between periphyton and functional capacity for Rocky Flats Everglades wetlands

Figure 20. Relationship between periphyton and functional capacity for Marl Flats Everglades wetlands 47

Figure 21. Floating mat of periphyton showing 50 to 100 percent cover 48

Figure 22. Reference standard Organic Flats Everglades dominated by Cladium jamaicense (saw grass). 51

Figure 23. Relationship between percent concurrence of strata dominants and functional capacity 51

Figure 24. Relationship between macrophytic vegetation and functional capacity for Rocky Flats Everglades wetlands 55

Figure 25. Relationship between macrophytic vegetation and functional capacity for Marl Flats Everglades wetlands 56

Figure 26. Relationship between macrophytic vegetation and functional capacity for Organic Flats Everglades wetlands

Figure 27. Percent cover of emergent macrophytic vegetation in reference standard Rocky Flats Everglades wetland showing 20 to 45 percent cover.

Figure 28. Relationship between periphyton and functional capacity for Rocky Flats Everglades wetlands

Figure 29. Relationship between periphyton and functional capacity for Marl Flats Everglades wetlands 59

Figure 30. Periphyton formed around stem 59

Figure 31. Relationship between percent cover of invasive vegetation and functional capacity.

Figure 32. Removal of Melaleuca quinquenervia (melaleuca) as part of wetland restoration. 64

Figure 33. Reference standard Marl Flats Everglades wetland dominated by Cladium jamaicense (saw grass), Spartina alterniflora (smooth cordgrass), Rhynchospora tracyi (Tracy's beaksedge), and Utricularia purpurea (eastern purple bladderwort) .66 
Figure 34. Relationship between percent concurrence of strata dominants and functional capacity

Figure 35. Surface soil texture of rock due to scraping and removal of the natural organic soil.

Figure 36. Relationship between soil thickness and functional capacity .........70

Figure 37. Pomacea paludosa (apple snails) are the primary food of the Rostrhamus sociabilis (snail kite) 75

Figure 38. Alligator mississippiensis (American alligator) 76

Figure 39. Relationship of assessment area to the larger area of contiguous wetland of the same subclass for determining wetland tract..... .77

Figure 40. Wetland tract size for Rocky and Marl Flats Everglades wetlands and functional capacity ..... .78

Figure 41. Wetland tract size for Organic Flats Everglades wetlands and functional capacity

Figure 42. The eastern portion of this aerial photograph shows many areas that would have very small tract sizes and little habitat connectivity.....

Figure 43. This portion of Shark River Slough in Everglades National Park would have very large tract size and 100 percent habitat connectivity 80

Figure 44. Interior core area and buffer zone 81

Figure 45. Interior core area for Rocky and Marl Flats Everglades wetlands and functional capacity..... .81

Figure 46. Interior core area for Organic Flats Everglades wetlands and functional capacity.

Figure 47. Adjacent habitats which are considered connected and not connected for determining $V_{C O N N E C T}$

Figure 48. Relationship between perimeter tract connections and functional capacity .84

Figure 49. Relationship between soil thickness and functional capacity .86

Figure 50. Microtopography altered by land leveling in the Marl Flats subclass 
Figure 51. Relationship between macrophytic vegetation and functional capacity for Rocky Flats Everglades wetlands

Figure 52. Relationship between macrophytic vegetation and functional capacity for Marl Flats Everglades wetlands

Figure 53. Relationship between macrophytic vegetation and functional capacity for Organic Flats Everglades wetlands

Figure 54. Relationship between periphyton and functional capacity for Rocky Flats Everglades wetlands ......

Figure 55. Relationship between periphyton and functional capacity for Marl Flats Everglades wetlands 92

Figure 56. Periphyton on surface

Figure 57. Relationship between percent cover of invasive vegetative cover and functional capacity

Figure 58. Casuarina equisetifolia (Australian pine) invading an area of Rocky Flats Everglades wetlands

Figure 59. Relationship between percent concurrence of strata dominants and functional capacity

Figure 60. A single WAA within a project area...... 103

Figure 61. Spatially separated WAAs from the same regional wetland subclass within a project area 103

Figure 62. More than one regional wetland subclass within a project area ...103

Figure 63. WAA defined based on differences in site-specific characteristics. 104

Figure 64. Sample field data sheet for Rocky Flats Everglades wetlands...... 105

Figure 65. Sample field data sheet for Marl Flats Everglades wetlands 106

Figure 66. Sample field data sheet for Organic Flats Everglades wetlands ...107

Figure 67. Divide the WAA in quadrants 108

Figure 68. Select a minimum of three quadrants for sampling 109

Figure 69. Sample plot and subplot dimensions and layout for field sampling

Figure 70. Example of an FCI calculation spreadsheet 111 


\section{List of Tables}

Table 1. Hydrogeomorphic Wetland Classes at the Continental Scale...........5

Table 2. Potential Regional Wetland Subclasses in Relation to Geomorphic Setting, Dominant Water Source, and Hydrodynamics .................... 6

Table 3. Reference Wetland Terms and Definitions ...................................

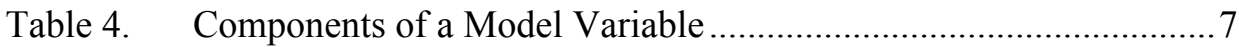

Table 5. Distinguishing Features of Marl, Rocky, and Organic Flats

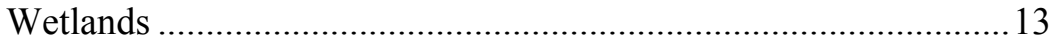

Table 6. Common Types of Anthropogenic and Natural Stresses on Wetlands in the Florida Everglades ..............................................21

Table 7. Soil Surface Texture for Rocky and Marl Flats Everglades Wetlands 29

Table 8. Soil Surface Texture for Organic Flats Everglades Wetlands .........30

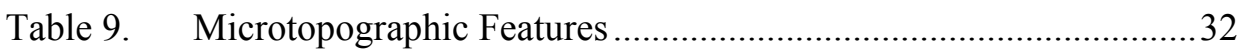

Table 10. Soil Surface Texture for Rocky and Marl Flats Everglades Wetlands

Table 11. Soil Surface Texture for Organic Flats Everglades Wetlands ........41

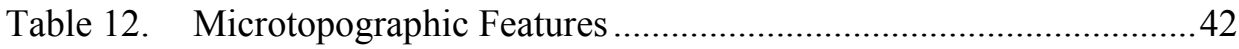

Table 13. Dominant Plant Species, Marl Flats...............................................50

Table 14. Dominant Plant Species, Organic Flats .......................................50

Table 15. Number of Native Wetland Species in Rocky Flats Everglades Wetlands ............................................................................ 52

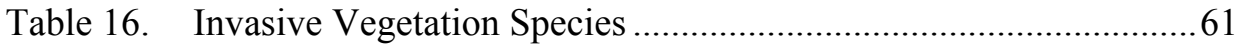

Table 17. Dominant Plant Species, Marl Flats.................................................65

Table 18. Dominant Plant Species, Organic Flats .........................................65

Table 19. Number of Native Wetland Species in Rocky Flats Everglades Wetlands .67 
Table 20. Soil Surface Texture for Rocky and Marl Flats Everglades Wetlands

Table 21. Soil Surface Texture for Organic Flats Everglades Wetlands ........69

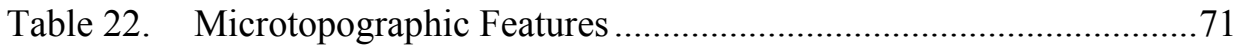

Table 23. Soil Surface Texture for Rocky and Marl Flats Everglades Wetlands 85

Table 24. Soil Surface Texture for Organic Flats Everglades Wetlands ........85

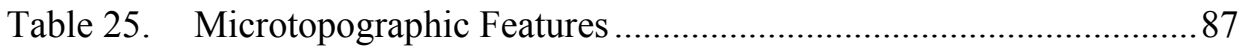

Table 26. Dominant Plant Species, Marl Flats..............................................95

Table 27. Dominant Plant Species, Organic Flats ….....................................96

Table 28. Number of Native Wetland Species in Rocky Flats Everglades

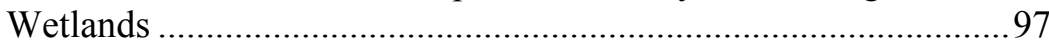

Table 29. Red Flag Features and Respective Program/Agency Authority ... 102

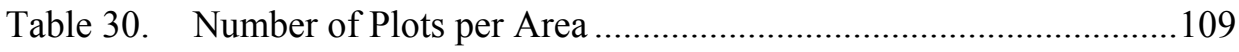




\section{Preface}

This Regional Guidebook was authorized by Headquarters, U.S. Army Corps of Engineers (HQUSACE), as part of the Characterization and Restoration of Wetlands Research Program (CRWRP). It is published as an Operational Draft for field testing for a 2-year period. Comments should be submitted via the Internet at the following address: http://www.wes.army.mil/el/wetlands/hgmhp. html. Written comments should be addressed to:

Department of the Army

Research and Development Center

CEERD-EE-W

3909 Halls Ferry Road

Vicksburg, MS 39180-6199

The work was performed under Work Unit 32985, "Technical Development of HGM," for which Dr. Ellis J. Clairain, Jr., Environmental Laboratory (EL), Vicksburg, MS, U.S. Army Engineer Research and Development Center (ERDC), was the Principal Investigator. Mr. Dave Mathis, CERD-C, was the CRWRP Coordinator at the Directorate of Research and Development, HQUSACE; Ms. Colleen Charles, CECW-OR, served as the CRWRP Technical Monitor's Representative; Dr. Russell F. Theriot, EL, Vicksburg, MS, ERDC, was the CRWRP Program Manager; and Dr. Clairain was the Task Area Manager.

This report was prepared by Mr. Chris V. Noble, EL; Ms. Rhonda Evans, U.S. Environmental Protection Agency (EPA) Region IV; Dr. Marti McGuire, Florida Department of Natural Resources; Ms. Katherine Trott, HQUSACE; Dr. Mary Davis, National Wildlife Federation; and Dr. Clairain.

The authors wish to acknowledge the efforts of the following people, without whom this document would not have been possible: Jim Beever, Florida Game and Freshwater Fish Commission; Boyd Gunsalus and Steve Krupa, South Florida Water Management District; Ken Liudahl, U.S. Department of Agriculture Natural Resources Conservation Service; and Stuart Santos, U.S. Army Engineer District, Jacksonville; who attended the workshop and provided a great deal of thoughtful and constructive insight into the development of these models; and Beth Burger, U.S. Environmental Protection Agency, for her diligence in the field during the field data collection when she collected much of the information for this Guidebook. 
This work took place under the general supervision of Dr. Morris Mauney, Jr., Chief, Wetlands and Coastal Ecology Branch; Dr. David J. Tazik, Chief, Ecosystem Evaluation and Engineering Division; and Dr. Edwin A. Theriot, Director, EL.

At the time of publication of this report, Dr. James R. Houston was Director of ERDC, and COL John W. Morris III, EN, was Commander and Executive Director.

This report should be cited as follows:

Noble, C. V., Evans, R., McGuire, M., Trott, K., Davis, M., and Clairain, E. J., Jr. (2002). "A regional guidebook for applying the Hydrogeomorphic Approach to assessing wetland functions of flats wetlands in the Everglades," Technical Report ERDC/EL TR-02-19, U.S. Army Engineer Research and Development Center, Vicksburg, MS.

The contents of this report are not to be used for advertising, publication, or promotional purposes. Citation of trade names does not constitute an official endorsement or approval of the use of such commercial products. 


\section{Introduction}

\section{Background}

The Hydrogeomorphic (HGM) Approach is a collection of concepts and methods for developing functional indices, and subsequently using them to assess the capacity of a wetland to perform functions relative to similar wetlands in a region. The approach was initially designed to be used in the context of the Clean Water Act Section 404 Regulatory Program permit review sequence to consider alternatives, minimize impacts, assess unavoidable project impacts, determine mitigation requirements, and monitor the success of mitigation projects. However, a variety of other potential applications for the approach have been identified, including determining minimal effects under the Food Security Act, designing mitigation projects, and managing wetlands.

On 16 August 1996 a National Action Plan to Implement the Hydrogeomorphic Approach (NAP) was published (Federal Register 1997). The NAP was developed cooperatively by a National Interagency Implementation Team consisting of the U.S. Army Corps of Engineers (USACE), U.S. Environmental Protection Agency (USEPA), National Resources Conservation Service (NRCS), Federal Highways Administration (FHWA), and U.S. Fish and Wildlife Service (USFWS). Publication of the NAP was designed to outline a strategy and promote the development of Regional Guidebooks for assessing the functions of regional wetland subclasses using the HGM Approach; to solicit the cooperation and participation of Federal, State, and local agencies, academia, and the private sector in this effort; and to update the status of Regional Guidebook development.

The sequence of tasks necessary to develop a Regional Guidebook outlined in the NAP was used to develop this Regional Guidebook (see "Development Phase" in Chapter 2). An initial workshop was held in Miami, FL, 8-11 May 1995, and was attended by hydrologists, biogeochemists, soil scientists, wildlife biologists, and plant ecologists from the public, private, and academic sectors with extensive knowledge of the Everglades ecosystem. Based on the results of the workshop, three regional wetland subclasses were defined and characterized, a reference domain was defined, wetland functions were selected, model variables were identified, and conceptual assessment models were developed. Subsequently, fieldwork was conducted to collect data from reference wetlands. These data were used to revise and calibrate the conceptual assessment models. 
A draft version of this Regional Guidebook was then subjected to several rounds of peer review and revised into the present document.

\section{Objectives}

The objectives of this Regional Guidebook are to (a) characterize the Everglades Flats Wetlands in Florida, (b) provide the rationale used to select functions for the marl, rocky, and organic subclasses, (c) provide the rationale used to select model variables and metrics, (d) provide the rationale used to develop assessment models, (e) provide data from reference wetlands and document its use in calibrating model variables and assessment models, and (f) outline the necessary protocols for applying the functional indices to the assessment of wetland functions.

\section{Scope}

This document is organized in the following manner. Chapter 1 provides the background, objectives, and organization of the document. Chapter 2 provides a brief overview of the major components of the HGM Approach and the Development and Application Phases required to implement the approach. Chapter 3 characterizes the marl, rocky, and organic subclasses in the Everglades Flats in terms of geographical extent, climate, geomorphic setting, hydrology, vegetation, soils, and other factors that influence wetland function. Chapter 4 discusses each of the wetland functions, model variables, and functional indices. This discussion includes a definition of the function; a quantitative, independent measure of the function for the purposes of validation; a description of the wetland ecosystem and landscape characteristics that influence the function, a definition and description of model variables used to represent these characteristics in the assessment model; a discussion of the assessment model used to derive the functional index; and an explanation of the rationale used to calibrate the index with reference wetland data. Chapter 5 outlines the steps of the assessment protocol for conducting a functional assessment of Everglades Flats Wetlands in Florida. Appendix A presents a Glossary. Appendix B provides summaries of functions, assessment models, variables, variable measures, and copies of the field data forms needed to collect field data. Appendix B also provides expanded discussions on how to measure selected assessment variables. Appendix $\mathrm{C}$ summarizes how to determine soil texture by feel and how to determine percent foliage cover, lists species found, and presents photos of the dominant species. Appendix D contains the data collected at reference wetlands.

While it is possible to assess the functions of flats wetlands in the Everglades using only the information contained in Chapter 5 and Appendix B, it is suggested that potential users familiarize themselves with the information in Chapters 2-4 prior to conducting an assessment. 


\section{Overview of the Hydrogeomorphic Approach}

The HGM Approach includes four main components: (a) the HGM classification, (b) reference wetlands, (c) assessment models/functional indices, and (d) assessment protocols. During the Development Phase, these four components are integrated into a Regional Guidebook for assessing the functions of a particular regional wetland subclass. Subsequently, during the Application Phase, end users follow the protocols outlined in the Regional Guidebook to assess the functional capacity of selected wetlands. Each of the components of the HGM Approach and the Development and Application Phases is described briefly in this Chapter. More extensive discussions can be found in Brinson (1993; 1995a, b), Brinson et al. (1995, 1996, 1998), Smith et al. (1995), Hauer and Smith (1998), Smith (2001), Smith and Wakeley (2001), and Wakeley and Smith (2001).

\section{Hydrogeomorphic Classification}

Wetland ecosystems share a number of features including relatively long periods of inundation or saturation, hydrophytic vegetation, and hydric soils. In spite of these common attributes, wetlands occur under a wide range of climatic, geologic, and physiographic situations and exhibit a wide variety of physical, chemical, and biological characteristics and processes (Cowardin et al. 1979, Semeniuk 1987, Mitsch and Gosselink 2000, Ferren, Fiedler, and Leidy 1996; Ferren et al. 1996a, b). The variability of wetlands makes it challenging to develop assessment methods that are both accurate (i.e., sensitive to significant changes in function) and practical (i.e., can be completed in the relative short time frame available for conducting assessments). Existing "generic" methods designed to assess multiple wetland types throughout the United States are relatively rapid, but lack the resolution necessary to detect significant changes in function. However, one way to achieve an appropriate level of resolution within the available time frame is to reduce the level of variability exhibited by the wetlands being considered (Smith et al. 1995). 
The HGM Classification was developed specifically to accomplish this task (Brinson 1993). It identifies groups of wetlands that function similarly using three criteria that fundamentally influence how wetlands function: geomorphic setting, water source, and hydrodynamics. Geomorphic setting refers to the landform and position of the wetland in the landscape. Water source refers to the primary water source in the wetland such as precipitation, overbank flooding, or groundwater. Hydrodynamics refers to the level of energy and the direction that water moves in the wetland. Based on these three classification criteria, any number of "functional" wetland groups can be identified at different spatial or temporal scales. For example, at a continental scale, Brinson (1993) identified five hydrogeomorphic wetland classes. These were later expanded to the seven classes described in Table 1 (Smith et al. 1995). In many cases, the level of variability in wetlands encompassed by a continental-scale hydrogeomorphic class is still too great to allow development of assessment models that can be applied rapidly while being sensitive enough to detect changes in function at a level of resolution appropriate to the Section 404 review process. For example, at a continental geographic scale the depression class includes wetland ecosystems in different regions as diverse as California vernal pools (Zedler 1987), prairie potholes in North and South Dakota (Hubbard 1988; Kantrud, Krapu, and Swanson 1989), playa lakes in the high plains of Texas (Bolen, Smith, and Schramm 1989), kettles in New England, and cypress domes in Florida (Kurz and Wagner 1953; Ewel and Odum 1984).

To reduce both inter- and intraregional variability, the three classification criteria are applied at a smaller, regional geographic scale to identify regional wetland subclasses. In many parts of the country, existing wetland classifications can serve as a starting point for identifying these regional subclasses (Stewart and Kantrud 1971; Golet and Larson 1974; Wharton et al. 1982; Ferren, Fiedler, and Leidy 1996; Ferren et al. 1996a, b). Regional subclasses, like the continental classes, are distinguished on the basis of geomorphic setting, water source, and hydrodynamics. In addition, certain ecosystem or landscape characteristics may also be useful for distinguishing regional subclasses in certain regions. For example, depressional subclasses might be based on water source (i.e., groundwater versus surface water), or the degree of connection between the wetland and other surface waters (i.e., the flow of surface water in or out of the depression through defined channels). Tidal fringe subclasses might be based on salinity gradients (Shafer and Yozzo 1998). Slope subclasses might be based on the degree of slope, landscape position, source of water (i.e., throughflow versus groundwater), or other factors. Riverine subclasses might be based on water source, position in the watershed, stream order, watershed size, channel gradient, or floodplain width. Examples of potential regional subclasses are shown in Table 2, Smith et al. (1995), and Rheinhardt, Brinson, and Farley (1997).

Regional Guidebooks include a thorough characterization of the regional wetland subclass in terms of its geomorphic setting, water sources, hydrodynamics, vegetation, soil, and other features that were taken into consideration during the classification process. 


\begin{tabular}{|c|c|}
\hline $\begin{array}{l}\text { Table } 1 \\
\text { Hydrogeol }\end{array}$ & 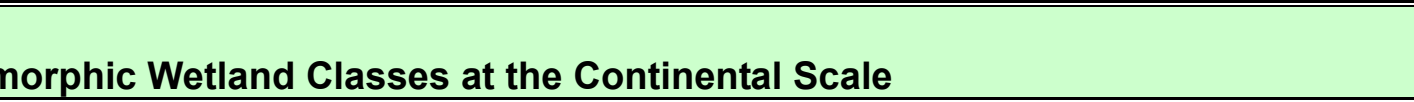 \\
\hline $\begin{array}{l}\text { HGM Wetland } \\
\text { Class }\end{array}$ & Definition \\
\hline Depression & $\begin{array}{l}\text { Depression wetlands occur in topographic depressions (i.e., closed elevation contours) that allow the } \\
\text { accumulation of surface water. Depression wetlands may have any combination of inlets and outlets or lack them } \\
\text { completely. Potential water sources are precipitation, overland flow, streams, or groundwater/interflow from } \\
\text { adjacent uplands. The predominant direction of flow is from the higher elevations toward the center of the } \\
\text { depression. The predominant hydrodynamics are vertical fluctuations that range from diurnal to seasonal. } \\
\text { Depression wetlands may lose water through evapotranspiration, intermittent or perennial outlets, or recharge to } \\
\text { groundwater. Prairie potholes, playa lakes, vernal pools, and cypress domes are common examples of } \\
\text { depression wetlands. }\end{array}$ \\
\hline Tidal Fringe & $\begin{array}{l}\text { Tidal fringe wetlands occur along coasts and estuaries and are under the influence of sea level. They intergrade } \\
\text { landward with riverine wetlands where tidal current diminishes and river flow becomes the dominant water source. } \\
\text { Additional water sources may be groundwater discharge and precipitation. The interface between the tidal fringe } \\
\text { and riverine classes is where bidirectional flows from tides dominate over unidirectional flow controlled by } \\
\text { floodplain slope of riverine wetlands. Because tidal fringe wetlands frequently flood and water table elevations are } \\
\text { controlled mainly by sea surface elevation, tidal fringe wetlands seldom dry for significant periods. Tidal fringe } \\
\text { wetlands lose water by tidal exchange, by overland flow to tidal creek channels, and by evapotranspiration. } \\
\text { Organic matter normally accumulates in higher elevation marsh areas where flooding is less frequent and the } \\
\text { wetlands are isolated from shoreline wave erosion by intervening areas of low marsh. Spartina alterniflora salt } \\
\text { marshes are a common example of tidal fringe wetlands. }\end{array}$ \\
\hline \begin{tabular}{|l} 
Lacustrine \\
Fringe
\end{tabular} & $\begin{array}{l}\text { Lacustrine fringe wetlands are adjacent to lakes where the water elevation of the lake maintains the water table in } \\
\text { the wetland. In some cases, these wetlands consist of a floating mat attached to land. Additional sources of } \\
\text { water are precipitation and groundwater discharge, the latter dominating where lacustrine fringe wetlands } \\
\text { intergrade with uplands or slope wetlands. Surface water flow is bidirectional, usually controlled by water-level } \\
\text { fluctuations resulting from wind or seiche. Lacustrine wetlands lose water by flow returning to the lake after } \\
\text { flooding and by evapotranspiration. Organic matter may accumulate in areas sufficiently protected from shoreline } \\
\text { wave erosion. Unimpounded marshes bordering the Great Lakes are an example of lacustrine fringe wetlands. }\end{array}$ \\
\hline Slope & $\begin{array}{l}\text { Slope wetlands are found in association with the discharge of groundwater to the land surface or sites with } \\
\text { saturated overflow with no channel formation. They normally occur on sloping land ranging from slight to steep. } \\
\text { The predominant source of water is groundwater or interflow discharging at the land surface. Precipitation is often } \\
\text { a secondary contributing source of water. Hydrodynamics are dominated by downslope unidirectional water flow. } \\
\text { Slope wetlands can occur in nearly flat landscapes if groundwater discharge is a dominant source to the wetland } \\
\text { surface. Slope wetlands lose water primarily by saturated subsurface flows and by evapotranspiration. Slope } \\
\text { wetlands may develop channels, but the channels serve only to convey water away from the slope wetland. Slope } \\
\text { wetlands are distinguished from depressional wetlands by the lack of a closed topographic depression and the } \\
\text { predominance of the groundwater/interflow water source. Fens are a common example of slope wetlands. }\end{array}$ \\
\hline $\begin{array}{l}\text { Mineral Soil } \\
\text { Flats }\end{array}$ & $\begin{array}{l}\text { Mineral soil flats are most common on interfluves, extensive relic lake bottoms, or large floodplain terraces where } \\
\text { the main source of water is precipitation. They receive virtually no groundwater discharge, which distinguishes } \\
\text { them from depressions and slopes. Dominant hydrodynamics are vertical fluctuations. Mineral soil flats lose } \\
\text { water by evapotranspiration, overland flow, and seepage to underlying groundwater. They are distinguished from } \\
\text { flat upland areas by their poor vertical drainage due to impermeable layers (e.g., hardpans), slow lateral drainage, } \\
\text { and low hydraulic gradients. Mineral soil flats that accumulate peat can eventually become organic soil flats. } \\
\text { They typically occur in relatively humid climates. Pine flatwoods with hydric soils are an example of mineral soil } \\
\text { flat wetlands. }\end{array}$ \\
\hline $\begin{array}{l}\text { Organic Soil } \\
\text { Flats }\end{array}$ & $\begin{array}{l}\text { Organic soil flats, or extensive peatlands, differ from mineral soil flats in part because their elevation and } \\
\text { topography are controlled by vertical accretion of organic matter. They occur commonly on flat interfluves, but } \\
\text { may also be located where depressions have become filled with peat to form a relatively large flat surface. Water } \\
\text { source is dominated by precipitation, while water loss is by overland flow and seepage to underlying groundwater. } \\
\text { They occur in relatively humid climates. Raised bogs share many of these characteristics but may be considered } \\
\text { a separate class because of the convex upward form and distinct edaphic conditions for plants. Portions of the } \\
\text { Everglades and northern Minnesota peatlands are examples of organic soil flat wetlands. }\end{array}$ \\
\hline Riverine & $\begin{array}{l}\text { Riverine wetlands occur in floodplains and riparian corridors in association with stream channels. Dominant water } \\
\text { sources are overbank flow from the channel or subsurface hydraulic connections between the stream channel and } \\
\text { wetlands. Additional sources may be interflow, overland flow from adjacent uplands, tributary inflow, and } \\
\text { precipitation. When overbank flow occurs, surface flows down the floodplain may dominate hydrodynamics. In } \\
\text { headwaters, riverine wetlands often intergrade with slope wetlands, depressions, poorly drained flats, or uplands } \\
\text { as the channel (bed) and bank disappear. Perennial flow is not required. Riverine wetlands lose surface water } \\
\text { via the return of floodwater to the channel after flooding and through surface flow to the channel during rainfall } \\
\text { events. They lose subsurface water by discharge to the channel, movement to deeper groundwater (for losing } \\
\text { streams), and evaporation. Peat may accumulate in off-channel depressions (oxbows) that have become isolated } \\
\text { from riverine processes and subjected to long periods of saturation from groundwater sources. Bottomland } \\
\text { hardwoods on floodplains are an example of riverine wetlands. }\end{array}$ \\
\hline
\end{tabular}




\begin{tabular}{|c|c|c|c|c|}
\hline \multicolumn{5}{|c|}{$\begin{array}{l}\text { Table } 2 \\
\text { Potential Regional Wetland Subclasses in Relation to Geomorphic Setting, Dominant } \\
\text { Water Source, and Hydrodynamics }\end{array}$} \\
\hline \multirow[b]{2}{*}{$\begin{array}{l}\text { Geomorphic } \\
\text { Setting }\end{array}$} & \multirow[b]{2}{*}{$\begin{array}{l}\text { Dominant Water } \\
\text { Source }\end{array}$} & \multirow[b]{2}{*}{$\begin{array}{l}\text { Dominant } \\
\text { Hydrodynamics }\end{array}$} & \multicolumn{2}{|c|}{ Potential Regional Wetland Subclasses } \\
\hline & & & Eastern United States & $\begin{array}{l}\text { Western United States/ } \\
\text { Alaska }\end{array}$ \\
\hline Depression & $\begin{array}{l}\text { Groundwater or } \\
\text { interflow }\end{array}$ & Vertical & $\begin{array}{l}\text { Prairie potholes, marshes, } \\
\text { Carolina bays }\end{array}$ & California vernal pools \\
\hline Fringe (tidal) & Ocean & Bidirectional, horizontal & $\begin{array}{l}\text { Chesapeake Bay and Gulf } \\
\text { of Mexico tidal marshes }\end{array}$ & $\begin{array}{l}\text { San Francisco Bay } \\
\text { marshes }\end{array}$ \\
\hline Fringe (lacustrine) & Lake & Bidirectional, horizontal & Great Lakes marshes & Flathead Lake marshes \\
\hline Slope & Groundwater & $\begin{array}{l}\text { Unidirectional, } \\
\text { horizontal }\end{array}$ & Fens & Avalanche chutes \\
\hline Flat (mineral soil) & Precipitation & Vertical & Wet pine flatwoods & Large playas \\
\hline Flat (organic soil) & Precipitation & Vertical & $\begin{array}{l}\text { Peat bogs; portions of } \\
\text { Everglades }\end{array}$ & $\begin{array}{l}\text { Peatlands over } \\
\text { permafrost }\end{array}$ \\
\hline Riverine & $\begin{array}{l}\text { Overbank flow from } \\
\text { channels }\end{array}$ & $\begin{array}{l}\text { Unidirectional, } \\
\text { horizontal }\end{array}$ & $\begin{array}{l}\text { Bottomland hardwood } \\
\text { forests }\end{array}$ & Riparian wetlands \\
\hline
\end{tabular}

\section{Reference Wetlands}

Reference wetlands are wetland sites selected to represent the range of variability that occurs in a regional wetland subclass as a result of natural processes and disturbance (e.g., succession, channel migration, fire, erosion, and sedimentation) as well as cultural alteration. The reference domain is the geographic area occupied by the reference wetlands (Smith et al. 1995). Ideally, the geographic extent of the reference domain will mirror the geographic area encompassed by the regional wetland subclass; however, this is not always possible due to time and resource constraints.

Reference wetlands serve several purposes. First, they establish a basis for defining what constitutes a characteristic and sustainable level of function across the suite of functions selected for a regional wetland subclass. Second, they establish the range and variability of conditions exhibited by model variables and provide the data necessary for calibrating model variables and assessment models. Finally, they provide a concrete physical representation of wetland ecosystems that can be observed and measured.

Reference standard wetlands are the subset of reference wetlands that perform the suite of functions selected for the regional subclass at a level that is characteristic of the least altered wetland sites in the least altered landscapes. Table 3 outlines the terms used by the HGM Approach in the context of reference wetlands.

\section{Assessment Models and Functional Indices}

In the HGM Approach, an assessment model is a simple representation of a function performed by a wetland ecosystem. It defines the relationship between one or more characteristics or processes of the wetland ecosystem. Functional 


\begin{tabular}{||l|l||}
\hline \multicolumn{2}{||l||}{$\begin{array}{l}\text { Table 3 } \\
\text { Reference Wetland Terms and Definitions }\end{array}$} \\
\hline \hline Term & Definition \\
\hline \hline $\begin{array}{l}\text { Reference } \\
\text { domain }\end{array}$ & $\begin{array}{l}\text { The geographic area from which reference wetlands representing the regional } \\
\text { wetland subclass are selected (Smith et al. 1995). }\end{array}$ \\
\hline $\begin{array}{l}\text { Reference } \\
\text { wetlands }\end{array}$ & $\begin{array}{l}\text { A group of wetlands that encompasses the known range of variability in the } \\
\text { regional wetland subclass resulting from natural processes and disturbance } \\
\text { and from human alterations. }\end{array}$ \\
\hline $\begin{array}{l}\text { Reference } \\
\text { standard } \\
\text { wetlands }\end{array}$ & $\begin{array}{l}\text { The subset of reference wetlands that performs a representative suite of } \\
\text { functions at a level that is both sustainable and characteristic of the least } \\
\text { human-altered wetland sites in the least human-altered landscapes. By } \\
\text { definition, functional capacity indices for all functions in reference standard } \\
\text { wetlands are assigned a value of 1.0. }\end{array}$ \\
\hline $\begin{array}{l}\text { Reference } \\
\text { standard wetland } \\
\text { variable } \\
\text { condition }\end{array}$ & $\begin{array}{l}\text { The range of conditions exhibited by model variables in reference standard } \\
\text { wetlands. By definition, reference standard conditions receive a variable } \\
\text { subindex score of 1.0. }\end{array}$ \\
\hline $\begin{array}{l}\text { Site potential } \\
\text { (mitigation } \\
\text { project context) }\end{array}$ & $\begin{array}{l}\text { The highest level of function possible, given local constraints of disturbance } \\
\text { history, land use, or other factors. Site potential may be less than or equal to } \\
\text { the levels of function in reference standard wetlands of the regional wetland } \\
\text { subclass. }\end{array}$ \\
\hline $\begin{array}{l}\text { Project target } \\
\text { (mitigation } \\
\text { project context) }\end{array}$ & $\begin{array}{l}\text { The level of function identified or negotiated for a restoration or creation } \\
\text { project. }\end{array}$ \\
\hline $\begin{array}{l}\text { Project } \\
\text { standards } \\
\text { (mitigation } \\
\text { context) }\end{array}$ & $\begin{array}{l}\text { Performance criteria and/or specifications used to guide the restoration or } \\
\text { creation activities toward the project target. Project standards should specify } \\
\text { reasonable contingency measures if the project target is not being achieved. }\end{array}$ \\
\hline
\end{tabular}

capacity is simply the ability of a wetland to perform a function compared to the level of performance in reference standard wetlands.

Model variables represent the characteristics of the wetland ecosystem and surrounding landscape that influence the capacity of a wetland ecosystem to perform a function. Model variables are ecological quantities that consist of five components (Schneider 1994): (a) a name, (b) a symbol, (c) a measure of the variable and procedural statements for quantifying or qualifying the measure directly or calculating it from other measures, (d) a set of variables (i.e., numbers, categories, or numerical estimates (Leibowitz and Hyman, in preparation) that are generated by applying the procedural statement, and (e) units on the appropriate measurement scale. Table 4 provides several examples.

\begin{tabular}{||l|l|l|l||}
\hline \hline $\begin{array}{l}\text { Table } 4 \\
\text { Components of a Model Variable }\end{array}$ & Units (Scale) \\
\hline \hline Name (Symbol) & Measure / Procedural Statement & $\begin{array}{l}\text { Resulting } \\
\text { Values }\end{array}$ & unitless \\
\hline $\begin{array}{l}\text { Number of Native } \\
\text { Wetland Species } \\
\left(V_{\text {NATIVE }}\right)\end{array}$ & Total number of native wetland species & 0 to $\geq 20$ & centimeters \\
\hline $\begin{array}{l}\text { Soil Thickness } \\
\left(V_{\text {SOILTHIKK })}\right.\end{array}$ & Average soil thickness over limestone & 0.0 to $>100.0$ & percent \\
\hline $\begin{array}{l}\text { Periphyton Cover } \\
\left(V_{\text {PERI })}\right.\end{array}$ & Percent cover of periphyton & 0 to $>100$ & \\
\hline
\end{tabular}


Model variables occur in a variety of states or conditions in reference wetlands. The state or condition of the variable is denoted by the value of the measure of the variable. For example, percent woody cover, the measure of the percent cover of trees and shrubs greater than $1 \mathrm{~m}$ in height, could range from 0 to 100 or more in the case of overlapping canopies. Based on its condition (i.e., value of the metric), each model variable is assigned a variable subindex. When the condition of a variable is within the range of conditions exhibited by reference standard wetlands, a variable subindex of 1.0 is assigned. As the condition deviates from the reference standard condition (i.e., the range of conditions that occurs in reference standard wetlands), the assigned variable subindex is based on the defined relationship between model variable condition and functional capacity. As the condition of a variable deviates from the conditions exhibited in reference standard wetlands, it receives a progressively lower subindex reflecting its decreasing contribution to functional capacity. In some cases, the variable subindex drops to zero. For example, when the percent cover of trees and/or shrubs is 80 percent or greater, the subindex for percent woody cover may be zero.

Model variables are combined in an assessment model to produce a Functional Capacity Index (FCI) that ranges from 0.0 to 1.0 . The FCI is a measure of the functional capacity of a wetland relative to reference standard wetlands in the reference domain. Wetlands with an FCI of 1.0 perform the function at a level that is characteristic of reference standard wetlands. As the FCI decreases, it indicates that the capacity of the wetland to perform the function is proportionately less than that characteristic of reference standard wetlands.

\section{Assessment Protocol}

The final component of the HGM Approach is the assessment protocol. The assessment protocol is a series of tasks, along with specific instructions, that allow the end user to assess the functions of a particular wetland area using the functional indices in the Regional Guidebook. The first task is characterization, which involves describing the wetland ecosystem and the surrounding landscape, describing the proposed project and its potential impacts, and identifying the wetland areas to be assessed. The second task is collecting the field data for model variables. The final task is analysis, which involves calculation of functional indices.

\section{Development Phase}

The Development Phase of the HGM Approach is ideally carried out by an interdisciplinary team of experts known as the Assessment Team, or A-Team. The product of the Development Phase is a Regional Guidebook for assessing the functions of a specific regional wetland subclass (Figure 1). In developing a Regional Guidebook, the A-Team will complete the following major tasks. After organization and training, the first task of the A-Team is to classify the wetlands 


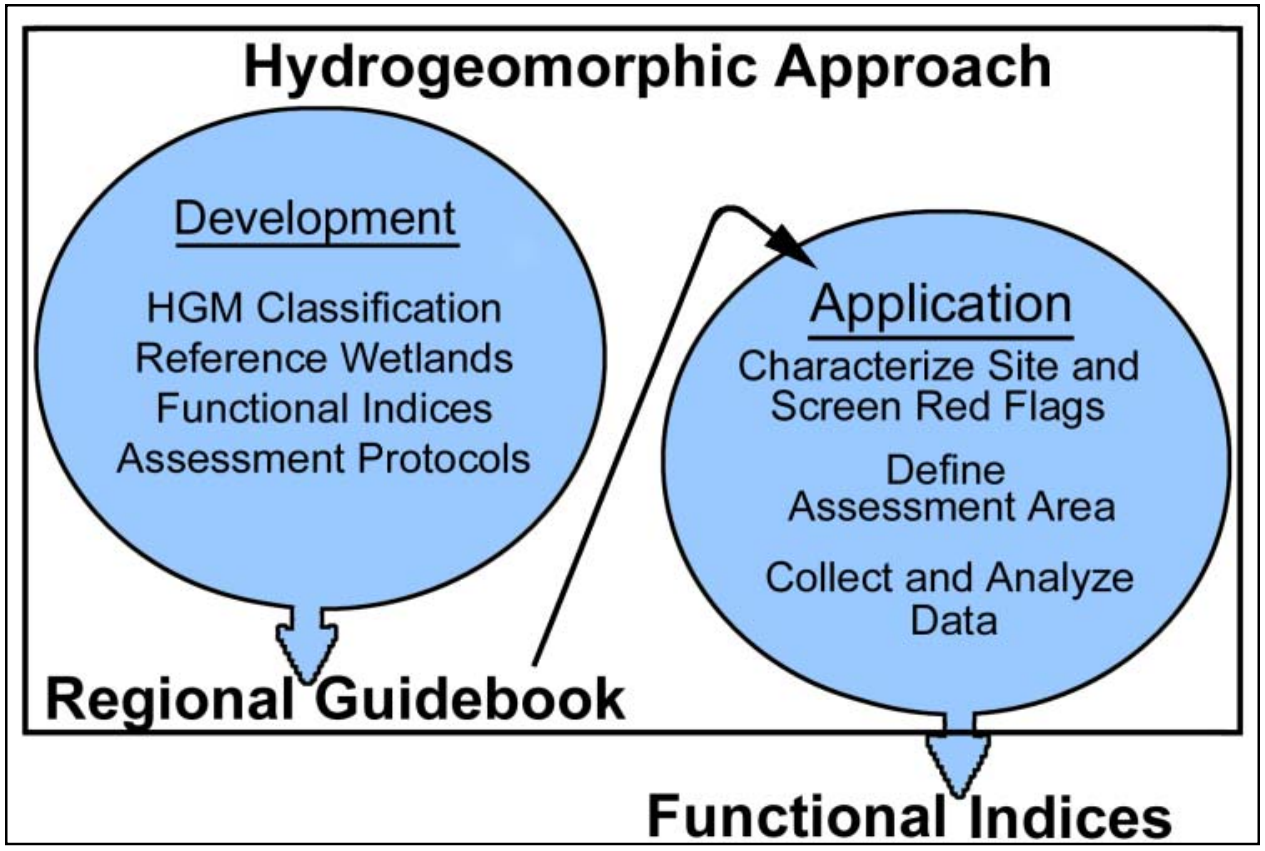

Figure 1. Development and application phases of the HGM Approach

within the region of interest into regional wetland subclasses using the principles and criteria of the Hydrogeomorphic Classification (Brinson 1993; Smith et al. 1995). Next, focusing on the specific regional wetland subclasses selected, the A-Team develops an ecological characterization or functional profile of the subclass. The A-Team then identifies the important wetland functions, conceptualizes assessment models, identifies model variables to represent the characteristics and processes that influence each function, and defines metrics for quantifying model variables. Next, reference wetlands are identified to represent the range of variability exhibited by the regional subclass. Field data are then collected from the reference wetlands and used to calibrate model variables and verify the conceptual assessment models. Finally, the A-Team develops the assessment protocols necessary for regulators, managers, consultants, and other end users to apply the indices to the assessment of wetland functions. The following list provides the detailed steps involved in this general sequence.

Task 1: Organize the A-Team
A. Identify A-Team members
B. Train A-Team in the HGM Approach

Task 2: Select and Characterize Regional Wetland Subclasses

A. Identify/prioritize wetland subclasses

B. Select regional wetland subclasses and define reference domain

C. Initiate literature review 
D. Develop preliminary characterization of regional wetland subclasses

E. Identify and define wetland functions

Task 3: Select Model Variables and Metrics and Construct Conceptual

Assessment Models

A. Review existing assessment models

B. Identify model variables and metrics

C. Define initial relationships between model variables and functional capacity

D. Construct conceptual assessment models for deriving FCI

E. Complete Precalibrated Draft Regional Guidebook (PDRG)

Task 4: Conduct Peer Review of PDRG

A. Distribute PDRG to peer reviewers

B. Conduct interdisciplinary, interagency workshop of PDRG

C. Revise PDRG to reflect peer review recommendations

D. Distribute revised PDRG to peer reviewers for comment

E. Incorporate final comments from peer reviewers on revisions into PDRG

Task 5: Identify and Collect Data from Reference Wetlands

A. Identify reference wetland field sites

B. Collect data from reference wetland field sites

C. Analyze reference wetland data

Task 6: Calibrate and Field Test Assessment Models

A. Calibrate model variables using reference wetland data

B. Verify and validate (optional) assessment models

C. Field test assessment models for ease of use and repeatability

D. Revise PDRG based on calibration, verification, validation (optional), and field testing results into a Calibrated Draft Regional Guidebook (CDRG)

Task 7: Conduct Peer Review and Field Test of CDRG

A. Distribute CDRG to peer reviewers

B. Field test CDRG

C. Revise CDRG to reflect peer review and field test recommendations

D. Distribute CDRG to peer reviewers' for final comment on revisions

E. Incorporate peer reviewers final comments on revisions

F. Publish Operational Draft Regional Guidebook (ODRG)

Task 8: Technology Transfer

A. Train end users in the use of the ODRG

B. Provide continuing technical assistance to end users of the ODRG

\section{Application Phase}

The Application Phase involves two steps. The first is using the assessment protocols outlined in the Regional Guidebook to carry out the following tasks (Figure 1): 
a. Define assessment objectives

b. Characterize the project site

c. Screen for red flags

d. Define the Wetland Assessment Area

e. Collect field data

f. Analyze field data

The second step involves applying the results of the assessment, the FCI, to the appropriate decision-making process of the permit review sequence, such as alternatives analysis, minimization, assessment of unavoidable impacts, determination of compensatory mitigation, design and monitoring of mitigation, comparison of wetland management alternatives or results, determination of restoration potential, or identification of acquisition or mitigation sites. 


\section{Characterization of Marl, Rocky, and Organic Flats Wetlands of the Florida Everglades}

Marjorie Stoneman Douglas described the Everglades as "a river of grass . . . they are changeless ... they are changed" (1947). It is a physiographic region unique to Florida and technically refers to the expanses of freshwater marsh originally extending from Lake Okeechobee to nearly the southern tip of the Florida mainland (Lodge 1994). The Everglades is considered to be one of the most threatened ecosystems in the nation. Populations of wading birds have declined to levels that verge on complete collapse of nesting activities in the Everglades (Light and Dineen 1994). Wetlands historically occupied 30 percent of the Florida landscape (Dahl 2000). Due to their prevalence and significant development pressures, 46 percent of the wetland acreage was lost in Florida by 1980 (Dahl 2000).

\section{Regional Wetland Subclasses and Reference Domain}

This Regional Guidebook was developed to assess the functions of three subclasses of freshwater wetlands in the Florida Everglades: Rocky, Marl, and Organic Flats Wetlands. The subclasses are distinguished primarily by soil type but also have functional differences in hydrology (Table 5). In spite of the differences in the soils, flats wetlands in the Everglades have many functional similarities. The surface water flow is typically unidirectional, the soils poorly and very poorly drained, and the terrain flat. They are primarily precipitation driven, but the surficial aquifers play an important role in their function. Seasonally high water tables in the surficial aquifers maintain the water levels necessary to support wetland communities. 


\begin{tabular}{|c|c|c|c|}
\hline \multicolumn{4}{|c|}{$\begin{array}{l}\text { Table } 5 \\
\text { Distinguishing Features of Marl, Rocky, and Organic Flats Wetlands }\end{array}$} \\
\hline Features & Rocky Flats & Marl Flats & Organic Flats \\
\hline Soils & $\begin{array}{l}\text { Shallow marl soils and } \\
\text { limestone rock outcrops with } \\
\text { solution holes } \\
\text { Depth of marl: Less than } \\
15 \mathrm{~cm} \text { ( } 6 \text { in.) }\end{array}$ & $\begin{array}{l}\text { Marl: limnic layer with a } \\
\text { moist Munsell color value } \geq 5 \\
\text { that reacts with dilute } \mathrm{HCl} \text { to } \\
\text { evolve } \mathrm{CO}_{2} \\
\text { Depth of marl: } 15-200+\mathrm{cm} \\
(6-80+\text { in.) }\end{array}$ & $\begin{array}{l}\text { Organic layer } \\
>20.3 \mathrm{~cm}(8 \mathrm{in} .) \\
\text { in depth or with } \\
\text { an organic layer } \\
>1 / 2 \text { the depth to } \\
\text { limestone } \\
\text { substrate }\end{array}$ \\
\hline $\begin{array}{l}\text { Average } \\
\text { annual water } \\
\text { levels above } \\
\text { the ground } \\
\text { surface }\end{array}$ & $30 \mathrm{~cm}$ (12 in.) & $30 \mathrm{~cm}$ (12 in.) & $76 \mathrm{~cm}$ (30 in.) \\
\hline $\begin{array}{l}\text { Duration of } \\
\text { inundation }\end{array}$ & $2-4$ months & $2-9$ months & $9-12$ months \\
\hline
\end{tabular}

According to Smith et al. (1995), the reference domain is the geographic area occupied by the reference wetland sites. The reference domain for this guidebook is the Everglades in portions of the southern six counties of Florida (Figure 2). The model variables are calibrated based on reference wetland sites located in Broward, Collier, Dade, Glades, Hendry, Monroe, and Palm Beach Counties (Appendix D). However, the functional models in this guidebook may apply to Organic Flats Wetlands outside of the reference domain (rocky and marl soil types are thought to be confined to the south Florida Everglades). Application of these models to areas outside south Florida is at the discretion of the user.

\section{Description of the Regional Wetland Subclasses}

The Rocky, Marl, and Organic Flats Wetlands of the Florida Everglades are distinctive due to their unique combination of geology, geomorphic setting, climate, soils, water source, hydrodynamics, and biota. The Florida Everglades are part of a very extensive, hydrologically connected, and unique ecosystem. This ecosystem has been significantly altered as part of the development of south Florida. The geologic development of the Everglades, geomorphic setting, climate, and hydrologic features of this unique system are discussed first in order to provide the context for understanding the three subclasses in the HGM model. Specific features of the soils, biota, and hydrology are then provided for each of the subclasses. The last section provides information on the disturbances that have occurred and how they affect the Rocky, Marl, and Organic Flats Wetlands of the Everglades.

\section{Geology}

The Everglades developed in recent geologic time during a globally controlled convergence of both climatic change and sea level rise within a shallow bedrock basin located in south Florida. This unique wetland ecosystem generally overlays the Miami geologic formation (Gleason and Stone 1994). The recession 


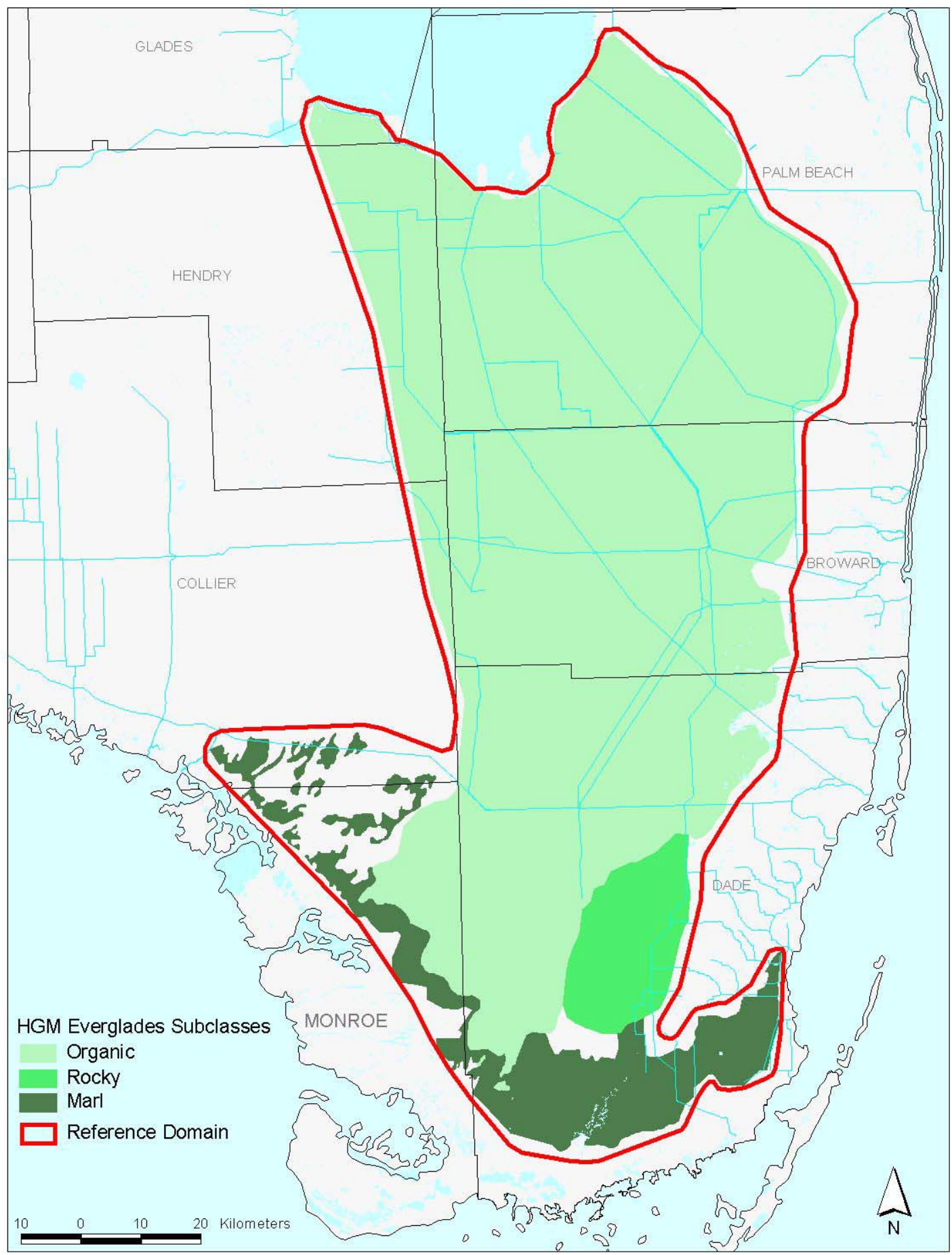

Figure 2. Reference domain for the Rocky, Marl, and Organic Flats Everglades wetlands, which corresponds to the historic freshwater Everglades 
of glaciers in northern North America at the end of the Pleistocene period and the change to a subtropical climate in south Florida provided both the abundant precipitation and seasonal rainfall climate necessary for the generation of the Everglades wetland ecosystem. The rising sea level has undoubtedly retarded runoff and downward leakage and helped to retain water within the Everglades basin. This, in turn, has allowed thick accumulations of organic matter (3-3.7 m) to develop within the deeper parts of the basin. The eastern coastal ridge, which was necessary to retain water, and in part defines the Everglades basin, owes its origin to marine geologic deposition which last occurred during the Sangamon interglacial age (about 125,000 years ago) when the sea level was up to $8 \mathrm{~m}$ above the present level. Repeated alterations between freshwater and marine conditions are revealed for interglacial times by limestone rock record, with freshwater limestone layers occurring within the generally marine limestone sequence. Rising sea levels over the past 5,000-6,000 years have caused the Everglades and coastal salt marshes at the southern end of the Everglades basin to transgress over previously freshwater habitats (Gleason and Stone 1994).

\section{Geomorphic setting}

As a result of its long submerged history, the Florida peninsula is a broad platform built of stable sedimentary rocks (principally limestones ranging from ancient to very recent age), layered over the ancient basement of African origin (Lodge 1994). To the east, the plateau drops off abruptly into the Atlantic, and to the west it slopes gradually far out into the Gulf of Mexico before receding into deep water (Lodge 1994). South of Lake Okeechobee, this plateau is so flat that only the direction of water flow can indicate which way is downhill (Hoffmeister 1974).

The Everglades are part of a much larger watershed encompassing $28,205 \mathrm{~km}^{2}$ (10,890 square miles) and including the Kissimmee River, Lake Okeechobee, the Everglades, and the Shark River Slough which ultimately flows into Florida Bay (Figure 3). Prior to drainage and the installation of levees around Lake Okeechobee and other water structures, this system was connected hydrologically. The Kissimmee River discharges into Lake Okeechobee, and historically during wet cycles the lake would overflow its south bank, providing additional flow to the Everglades (Light and Dineen 1994). Because of the low gradient of the landscape, surface water flow is unidirectional. However, there is a general flow of water in the Everglades from north to south (Figure 3).

Wetlands dominate the Everglades ecosystem, covering most of central and south Florida. The landscapes included swamp forests; sawgrass plains; mosaics of sawgrass, tree islands, and ponds; marl-forming prairies dominated by periphyton; wet prairies dominated by spikerush and waterlilies; freshwater marshes; saltwater marshes; cypress strands; and a vast lake-river system draining into Lake Okeechobee. Elevated areas that normally did not flood supported pine flatwoods, pine rocklands, scrub, tropical hardwood hammocks, and xeric hammocks dominated by oaks (Davis 1943). All these habitats were interconnected on an extremely low topographic gradient $(2.9 \mathrm{~cm} / \mathrm{km})$ with elevations 


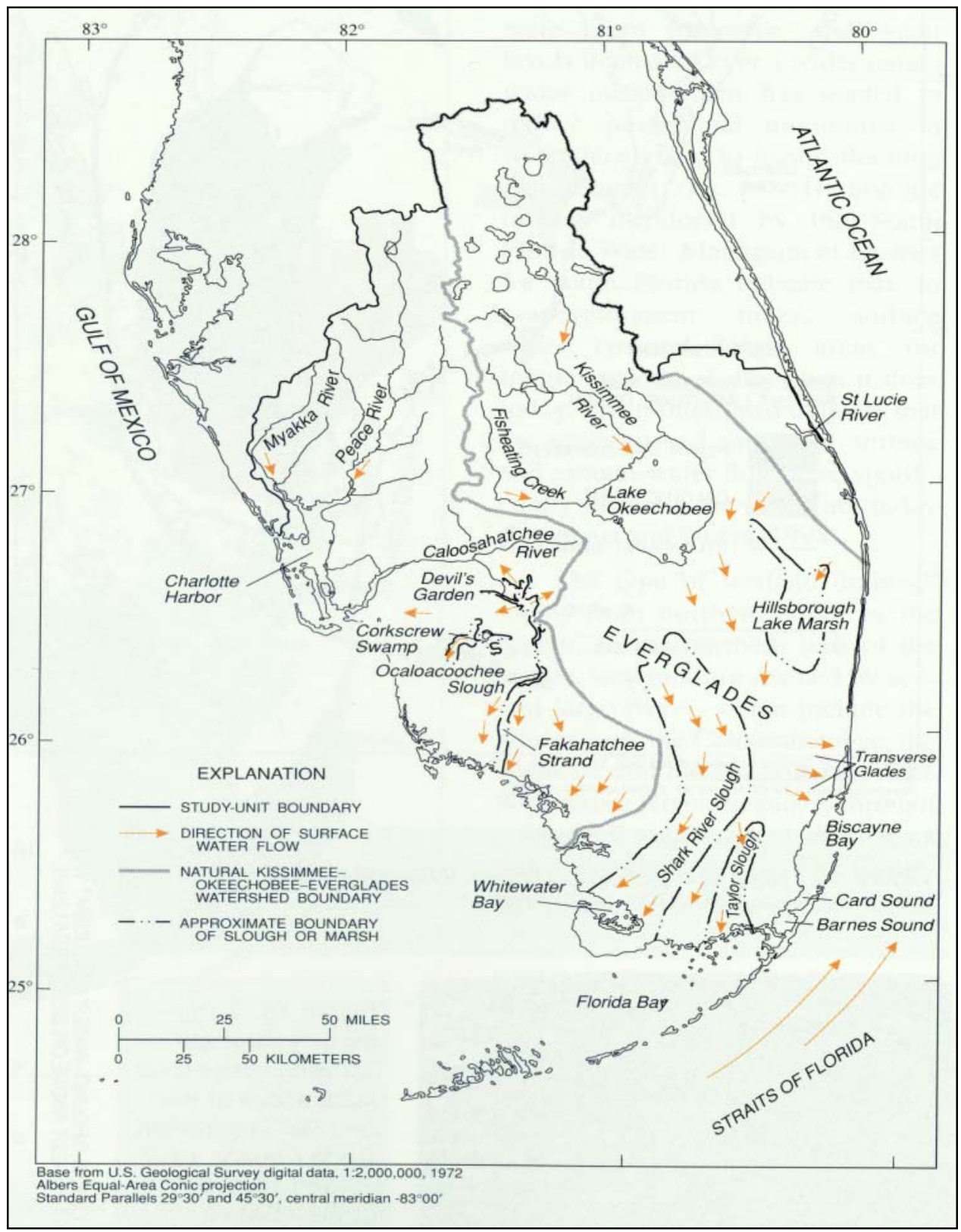

Figure 3. General direction of surface water flow in south Florida including the Everglades

ranging from about $6 \mathrm{~m}$ at Lake Okeechobee to below sea level at Florida Bay (Science Subgroup 1994). Historically there were no open channels through the Everglades and the average wet-season maximum depths were probably between 0.3 and $0.6 \mathrm{~m}$ (1 and $2 \mathrm{ft}$ ) (Lodge 1994). 


\section{Climate}

The climate of the Everglades is tropical to subtropical with a summer wet season and a dry season from midfall through late spring. Average temperatures are warm all year with occasional freezes in some years. Freezes play a large role in controlling the distribution of tropical flora and fauna in south Florida. In some years, the Everglades has sufficiently large areas of standing water during the winter months to moderate cold temperatures (Duever et al. 1994). Whether or not southern Florida is truly tropical is often debated since damaging frosts recur about every other year (Thomas 1974; Wade, Ewel, and Hofstetter 1980). The sensitivity of tropical plants to cold is the main factor that determines their northern limits, and a northward restriction to the coast is the standard pattern of their distribution (Lodge 1994).

The major source of rainfall is thunderstorms, although winter cold fronts and hurricanes can contribute significantly in some years. The average annual rainfall is 127 to $152 \mathrm{~cm}$ (50 to 60 in.) (Carlisle and Watts 1995). The Everglades wetlands exist where the water table is at times above and at other times below the ground surface for extended periods during an average annual cycle. The major factors affecting the timing and extent of this fluctuation are precipitation and evapotranspiration. These processes result in a distinctive pattern of heavy rainfall and high water levels during the summer months and a dry season and lower water levels from midfall through late spring. The timing and extent of droughts are highly variable and can significantly affect faunal and floral communities.

\section{Water sources and hydrodynamics}

The Everglades are primarily precipitation driven and are maintained by a high groundwater table. Evapotranspiration is a particularly important aspect of the Everglades climate because it is the primary mechanism by which water leaves the ecosystem, exporting an estimated 70-90 percent of the rainfall entering these systems (Dohrenwend 1977). Hydrologic processes result in a distinctive pattern of heavy rainfall and high water levels during the summer months, followed by a slow decline in the water table during the winter and a much more rapid decline during the spring (Duever et al. 1994).

The average hydroperiod for a sawgrass marsh is about 10 months, but it ranges from less than 6 months to nearly continuous flooding (Lodge 1994). The hydroperiod of the wet prairie is the shortest of all the marsh types, averaging between 3 and 5 months (Lodge 1994). Tropical Bioindustries (1990) estimated that the hydroperiod for calcareous periphyton is 6 to 7 months.

Discharges occur through evapotranspiration, groundwater flow to canals and the sea, and wells pumped for municipal and agricultural use (Fish and Stewart 1991). The construction of wellfields can affect the local groundwater table, thereby altering water tables and vegetative communities (Hofstetter and Sonenshein 1990). The wetland hydroperiod affects the composition of the 
periphyton community. Van Meter-Kasanof (1973) concluded that periphyton with a larger component of green algae required year-round flooding; hydroperiods of 5 to 7 months promoted the occurrence of cyanobacteria (blue-green algae).

In the periodic droughts, central sloughs, ponds, solution holes, and alligator holes appear as isolated entities and generate a sudden and explosive increase in edges providing habitat at microtopographic scales under a few tens of meters. These small depressions retain water long after the surface marsh dries, thereby concentrating food and acting as aquatic refugia. They provide a shifting set of feeding concentrations somewhere within the foraging territory of many wading birds throughout the nesting season (Holling, Gunderson, and Walters 1994; Kushlan 1976; Kushlan 1986).

\section{Biological and soil profile}

By virtue of its geographic location on a peninsula extending from a temperate continent into the subtropics, the Everglades has a flora comprising tropical, temperate, and endemic taxa (Gunderson 1994). Since the turn of the century, approximately one-half of the 1.2 million hectares ( 3 million acres) once covered by Everglades wetlands have been converted for agriculture and urban development (Davis et al. 1994). Three of seven predrainage landscapes, custard apple forest, peripheral wet prairie, and cypress forest, have disappeared completely; and three-fourths of a dense, monotypic sawgrass plain that once covered the northern Everglades has been replaced by agricultural crops (Davis et al. 1994). The other landscape units, including the wet prairie-slough-sawgrass-tree island mosaic, the sawgrass-dominated mosaic, and the southern marl marshes, have decreased in spatial extent to a lesser degree (Davis et al. 1994).

The major plant communities of the Everglades, grouped by major ecological classes, include upland communities (e.g., rockland pine forests, tropical hardwood hammocks), wetland communities (e.g., freshwater wetland tree islands such as bayheads, willow heads, and cypress forests; graminoid associations such as sawgrass marshes, spike rush, beak rush, and maidencane marshes; and wet marl prairies), and unvegetated systems such as ponds, creeks, and sloughs (Loveless 1959; White 1994).

Shifts in fish assemblage dominance in the Everglades marshes may occur coincidentally with long periods of water level stability, but not within a small temporal scale (Loftus and Eklund 1994). A wide range of macroinvertebrates, amphibians, and reptiles, as well as birds, occurs in the Everglades marshes (O'Hare and Dalrymple 1997). Dense sawgrass is a habitat where alligators often build their nests (Lodge 1994). The American alligator is the only large, abundant, nonmarine carnivore left in the southeastern United States and is considered a keystone species within the Everglades and other marsh systems, acting as predator and prey and structuring plant communities (Mazzotti and Brandt 1994). The snail kite, a federally listed endangered species, is a highly specialized raptor whose diet in the Everglades consists almost exclusively of 
one species of aquatic snail, the apple snail. Snail kites exhibited a period of substantial decline during the early to mid-1900's, which coincided with largescale drainage projects (Bennetts, Collopy, and Rogers 1994).

Specific characteristics of the soils, plants, and animals for each of the three glades subclasses are discussed in the following sections.

\section{Rocky flats}

Rocky Flats Wetlands are composed of a combination of shallow marl soils and outcrops of oolitic limestone rock (U.S. Department of Agriculture (USDA) 1996). Organic matter and marl are found in the solution holes or depressions of the pitted rock substrate in which variable thicknesses of leaf litter accumulate in the time periods between fires (Gunderson 1994). The depth of marl, when present, is less than $15 \mathrm{~cm}(6 \mathrm{in}$.$) . The average annual water levels are about 30 \mathrm{~cm}$ (12 in.) with duration of inundation of 2 to 4 months. The large solution holes in the limestone are important for retaining water during dry times and providing habitat for water-dependent wildlife species. Conversion of this habitat for agriculture or other uses is permanent; the jagged topography with its small solution holes and rocky, impermeable substrate cannot be restored or recreated. Areas that have been rock-plowed (limestone rock and marl are ground to a mixture of coarse and fine particles to form a different soil) can be modified to support native wetland vegetation, but Brazilian pepper usually dominates an abandoned wetland site (Dalrymple, Dalrymple, and Fanning 1993).

The Rocky glades are dominated by saw grass, muhly grass, panic grasses, and beak rushes. The deeper solution holes are frequently filled with marl and submerged aquatics, such as bladderworts. Upland tree islands are also present in the Rocky Flats subclass. Typical wildlife includes southeastern five-lined skink, ringneck snake, pygmy rattlesnake, red-shouldered hawk, Carolina wren, eastern bluebird, pine warbler, opossum, marsh rabbit, cotton rat, cotton mouse, raccoon, and bobcat (Florida Natural Areas Inventory and Florida Department of Natural Resources (FNAI) 1990).

\section{Marl flats}

The oldest postglacial wetland sediment dated from the Everglades is calcitic mud, a freshwater, frequently shelly, nonstratified, low-magnesium calcitic silt (Gleason and Spackman 1974). Marl is formed as dissolved calcite (biochemical extraction of calcium carbonate from the movement of overlying water) is reprecipitated as crystals or "needles" in a matrix of filaments of cyanobacteria (bluegreen algae) and green algae and diatoms in submerged algal mats (periphyton). Marl is defined as a limnic layer composed of organic and inorganic materials with a moist Munsell color value of 5 or more that reacts with dilute $\mathrm{HCl}$ to evolve $\mathrm{CO}_{2}$ (USDA 1999). Marls are found along coastal areas of Florida south of Lake Okeechobee (Noble 1989; Cooper et al. 1995). In marl flats, the depths of the marl are 15 to $200 \mathrm{~cm}$ or greater ( 6 to $80+$ in.). The average annual water 
levels are approximately $30 \mathrm{~cm}$ (12 in.) with a duration of inundation for 2 to 9 months most years.

The environment for marl deposition is a sparsely vegetated marsh where the water surface is well lighted for the photosynthesizing algae and there is considerable oxidation of organic material in the sediment throughout the years, especially during the dry season (Gleason and Stone 1994). In order for marl to be deposited, the rate of deposition of organic material must be low in comparison with the rate of deposition of algally precipitated calcite. The hydroperiod and water depth can affect the rate of organic matter production by aquatic plants and the rate of decomposition of organic matter (Browder, Gleason, and Swift 1994).

The periphyton community, made up of many taxa of microalgae, serves as a food web base as well as building calcitic mud sediment, oxygenating the water column, and forming a substantial part of the vegetation biomass of the Everglades (Browder, Gleason, and Swift 1994). Periphyton taxonomic composition is influenced by water quality (both nutrients and minerals) and hydroperiod (Browder, Gleason, and Swift 1994). It grows well in areas where the water chemistry is affected by nearby limestone exposures and appears to be less affected by water depth and hydroperiod than by water quality (Gleason and Stone 1994) but appears to be excluded from areas of cattail monoculture and mixed dense saw grass and cattail areas, which offers an explanation for depressed dissolved oxygen concentrations in these areas (Swift and Nicholas 1987). Periphyton is strongly season-dependent due to changes in the biomass of macrophytes (Vymazal and Richardson 1995). The presence of calcareous periphyton usually indicates a water depth of roughly $60 \mathrm{~cm}$ or less; at depths greater than $60 \mathrm{~cm}$, the algal mat degenerates into a crumbly mass or a thin coating of algae (Browder, Gleason, and Swift 1994).

Dominant plants species in the Marl Flats Everglades include saw grass, muhly grass, spike rush, bluestem, beak rush, and mermaid weed.

\section{Organic flats}

Organic soils are formed under anaerobic conditions when, due to insufficient oxygen because of flooding, microorganisms are unable to completely decompose plant remains to carbon dioxide, water, and mineral constituents (Snyder and Davidson 1994). Organic soils of the Everglades can form and persist only under conditions of permanent flooding and/or saturated soil conditions (Tropical Bioindustries 1990). When the soils are drained, the land surface will likely subside for a number of reasons: loss of buoyancy, peat shrinkage, fires, wind erosion, and, most importantly, aerobic microbiological decomposition (oxidation) (Snyder and Davidson 1994).

The average annual water depth in the Organic Flats Wetlands is approximately $76 \mathrm{~cm}$ (30 in.). The duration of inundation is 9 to 12 months. 
The Organic glades are dominated by saw grass, maiden cane, panic grasses, beak rushes, and several floating and submerged aquatic species, such as mermaid weed, pickerelweed, and bladderworts. The Organic glades support populations of southern dusky salamander, cricket frog, little grass frog, chicken turtle, striped mud turtle, ringneck snake, cottonmouth, hawks, wild turkey, great horned owl, barred owl, pileated woodpecker, neotropical migratory birds, grey squirrel, black bear, raccoon, mink, river otter, bobcat, and white-tailed deer (FNAI 1990).

\section{Disturbance}

Functional profiles of wetlands are often dependent in part on the natural occurrence of disturbances. In Florida, wetlands are naturally subjected to a variety of forces such as flooding and drought (Table 6) that act to maintain characteristic hydrologic regimes, substrate, and biota. If the natural timing of these events is disrupted for long periods of time, the wetlands change. In addition, anthropogenic disturbances and natural catastrophic events, such as hurricanes, can also alter characteristics of wetlands (Table 6). When the wetland hydrology, substrate, and biota are altered, the functional capacity of the wetland is altered as well.

\begin{tabular}{|c|c|}
\hline \multicolumn{2}{|c|}{$\begin{array}{l}\text { Table } 6 \\
\text { Common Types of Anthropogenic and Natural Stresses } \\
\text { on Wetlands in the Florida Everglades (Odum 1985) }\end{array}$} \\
\hline Anthropogenic & Natural \\
\hline Ditching / diking & $\begin{array}{l}\text { Fire (too frequent or infrequent) } \\
\end{array}$ \\
\hline Changes in land use & Frost or freeze \\
\hline Road & Wind (especially hurricanes) \\
\hline Excavation or filling & Droughts \\
\hline Silviculture & Flooding \\
\hline Changes in hydrology & Sea level changes \\
\hline \multicolumn{2}{|l|}{ Exotics } \\
\hline \multicolumn{2}{|l|}{ Pesticides / herbicides / toxins } \\
\hline Rock plowing (Rocky Flats) & \\
\hline Fire suppression and changes to fire regime & \\
\hline
\end{tabular}

Various historic drainage and municipal wellfield pumping projects (Light and Dineen 1994) have heavily impacted the Everglades. The development of water structures in the Everglades began about the turn of the century to encourage the settlement of the southern portion of the Florida peninsula. Early efforts at water control included the Everglades Drainage District works, consisting of $70.8 \mathrm{~km}$ (440 miles) of canals and levees, and the Okeechobee Flood Control District, which constructed a federally subsidized dike around the southern rim of Lake Okeechobee. Later, a massive federal project, the Central and Southern Florida Project for Flood Control and Other Purposes, was authorized by Congress after the massive flooding during 1948 (Light and Dineen 1994). The results of these and other projects have been massive interruptions to the natural flow of water through the Everglades and hydrologic modifications to the ecosystems of central and southern Florida (Figure 4). Large-scale alterations 


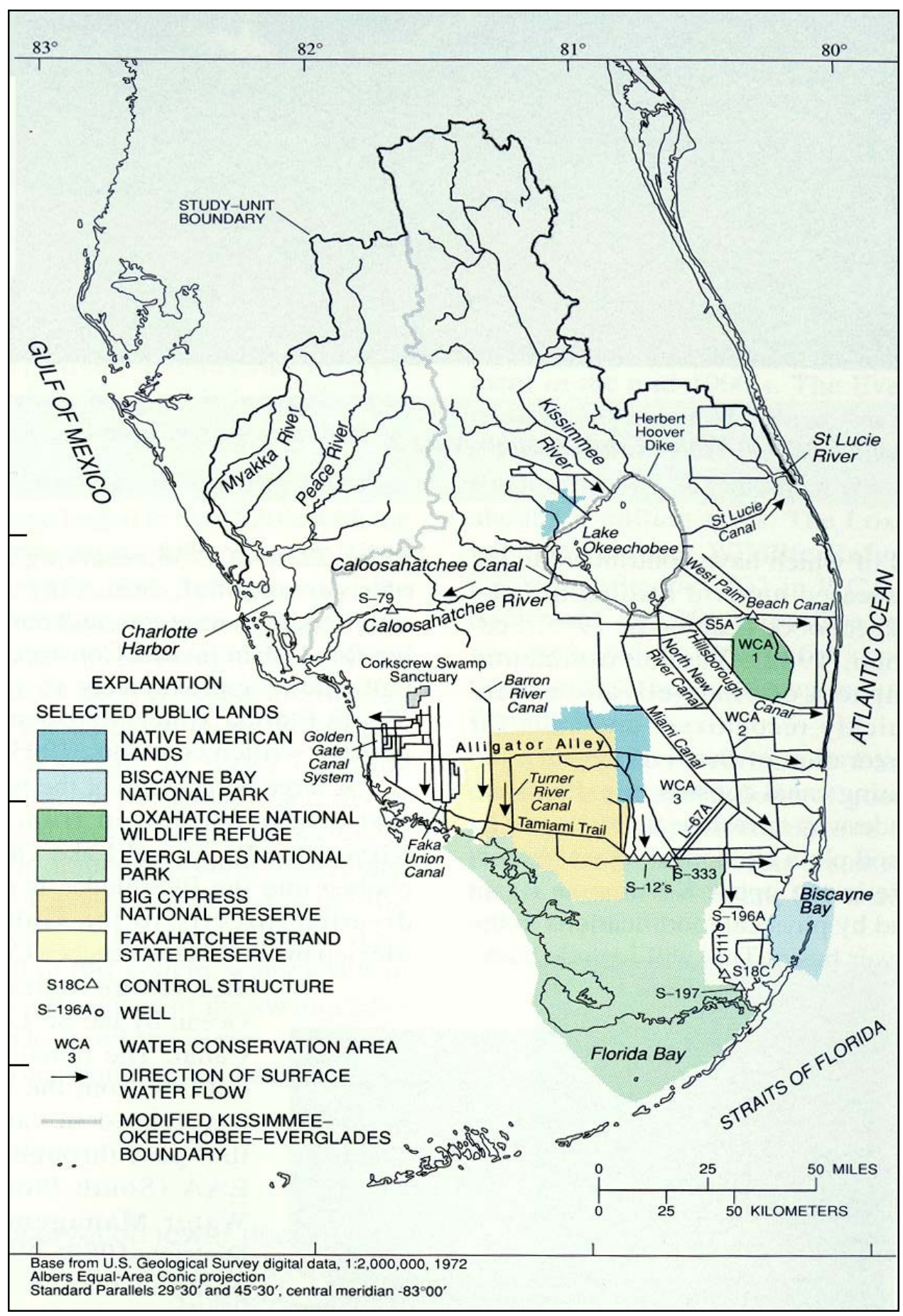

Figure 4. Alteration of the natural surface water flow through the Everglades by a network of canals 
include eliminating or greatly reducing a seasonal and coastal groundwater ridge, reducing deep groundwater circulation, reducing or eliminating seasonal westward movement of groundwater, causing accelerated stormwater runoff and shortened groundwater flow paths, and generally lowering the water table thereby inducing saltwater intrusion (Fish and Stewart 1991). Efforts are currently under way by state and federal agencies to mitigate some of the impacts of these projects, as well as impacts from agriculture and urban development, to the Everglades and Florida Bay (McIvor, Ley, and Bjork 1994).

Changes in the surrounding land use will alter both nutrients and contaminants flowing to a wetland. For instance, Gleason and Spackman (1974) found that the extent to which agricultural runoff influenced local water chemistry determined whether calcareous or noncalcareous periphyton was present. An increase in nitrogen has been found to eliminate the periphyton mat within months and significantly decrease the biomass, which remained only on submerged leaves and stems (Scheidt, Flora, and Walker 1987). Elevated inorganic phosphorus has been found to have similar effects (Stewart and Ornes 1975). The growing impact of developing the landscape surrounding the Everglades has had a large impact on the water quality of this oligotrophic system. Water in urban and agricultural canals commonly has high concentrations of nutrients and toxic compounds compared with water in marshes that are remote from canals (McPherson and Halley 1996).

Several factors, including its tropical climate, make south Florida particularly vulnerable to a proliferation of invasive plants. When species are transported to new environments that are similar to their natural habitat, they may become invasive due to a lack of natural predators and other controlling factors that are present in their native landscape. Exotic species often compete with and replace native species. Australian pine (Casuarina equisetifolia), Brazilian pepper (Schinus terebinthifolius), and melaleuca (Melaleuca quinquenervia) are the three most abundant exotic plant species found in the Everglades. Melaleuca drastically changes ecosystem structure and dynamics, including the hydrology, vegetation composition, and animal use (White 1994). It may be better adapted to a wider range of the current conditions than native species (Hofstetter and Sonenshein 1990). Soil types fail to limit the ability of melaleuca to take hold; the tree grows equally well in the deep peat soil of the Loxahatchee Wildlife Refuge or the inorganic, calcareous soil of western Dade County (Bodle, Ferriter, and Thayer 1994).

Reduction in the spatial extent of the Everglades and the shortened and interrupted hydroperiods have reduced the total productivity (Browder, Gleason, and Swift 1994). The overall loss of half of the Everglades wetland system has also resulted in a decline in aquatic productivity (Davis et al. 1994). This loss of wetlands has significantly reduced landscape heterogeneity, habitat options, and long-term population survival for animals with large spatial requirements. The fragmentation and loss of habitat have increasingly stressed many species. At present, USFWS has designated 18 species as threatened or endangered, and 12 more are under review to determine their status (South Florida Water Management District 1992; McPherson and Halley 1996). 
Wading birds form an important component of the Everglades marsh ecosystem and are often used as indicators of the health of the system (Hoffman, Bancroft, and Sawicki 1994). Although the Everglades still provides foraging habitat for large numbers of nonbreeding wading birds, the number of breeding birds has been reduced by approximately 90 percent (Bancroft 1989; Ogden 1994). In the Everglades, the quantity and timing of water flows in the system have become erratic enough to seriously affect the ability of wading birds to raise young (Kushlan 1987). The structural changes to the Everglades and the water management practices instituted over the past several decades have had major effects on breeding populations of wading birds (Bancroft et al. 1994). Restoration for animal populations, particularly wading birds, will require substantial increases in volumes of water flowing into the southern Everglades, reestablishment of longer hydroperiods in the higher elevation marshes, increased flows into the mainland estuaries, and reestablishment of nearly permanent flooding in the deeper central sloughs (Ogden 1994).

Two types of disturbances are specific to the subclass: rock plowing in Rocky Flats Wetlands and soil subsidence in Organic Flats. These are discussed in the following sections.

Rocky Flats. One of the primary activities of disturbance in Rocky Flats is rock plowing, primarily for agricultural purposes. Rock plowing is a method of grinding limestone rock and marl to a mixture of coarse and fine particles to form a "soil" using a plow specific for this purpose. Conversion of this habitat is permanent; the jagged topography with its small solution holes and rocky, impermeable substrate cannot be restored or recreated. Areas that have been rock-plowed can be modified to support wetland vegetation by lowering the substrate level, usually from 0.3 to $0.5 \mathrm{~m}$ (12 to $18 \mathrm{in}$.); however, the character and functioning of the subclass will not be the same. Unless the substrate level is lowered, an abandoned rocky site will likely be dominated by Brazilian pepper (Dalrymple, Dalrymple, and Fanning 1993).

Organic Flats. When organic soils are drained, the land surface may begin falling (subsiding) for a number of reasons: loss of buoyancy, peat shrinkage, fires, wind erosion, and, most importantly, aerobic microbiological decomposition (oxidation) (Snyder and Davidson 1994). The compaction and oxidation of organic soils in the agricultural lands south of Lake Okeechobee was one of the first observed environmentally destructive effects of large-scale

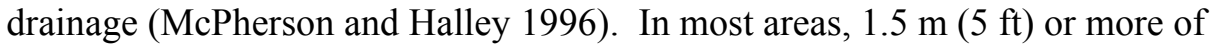
organic soil had been lost by 1984 (Stephens, Snyder, and Davidson 1994). The process of oxidative loss of soil continues, although the process has been slowed in some locations by reflooding fallow fields and maintaining a high water table (McPherson and Halley 1996).

This loss through subsidence has affected the Organic Flats as well as the overall hydrology and ecology of the Everglades in many ways. The loss of the soil changes the function of Organic Flats areas by altering plant species composition, changing habitat for wildlife, and altering the overall hydrology of the site. The large spatial extent of the loss has affected the Everglades 
ecosystem by changing the elevation gradient from the upper to the central Everglades. The loss of elevation has meant a loss of the hydraulic head that once caused water to flow south. The movement of water from north to south now requires pumpage. The soil loss also has reduced water-storage capacity, which has caused a reduction in the ability of the area to absorb water and mediate seasonal and long-term variations in rainfall (McPherson and Halley 1996).

Although pressure to develop the areas in and surrounding the Everglades will continue, there has been considerable effort at the state and federal level to study and restore the hydrology and functioning of this large ecosystem. Largescale, regional efforts are needed and under way for restoration while at the same time incremental encroachment by development and agriculture continues. Understanding the wetland functions of the glades subclasses as part of the regulatory 404 process will be instrumental in further efforts to protect and restore the Everglades. 


\section{Wetland Functions and Assessment Models}

The following functions performed by flats wetlands in the Everglades were selected for assessment:

a. Surface and Subsurface Water Storage

b. Biogeochemical Processes

c. Characteristic Plant Communities

d. Wildlife Habitat

The following sequence is used to present and discuss each of these functions:

a. Definition: defines the function and identifies an independent quantitative measure that can be used to validate the functional index.

b. Rationale for selecting the function: provides the rationale for why a function was selected and discusses onsite and offsite effects that may occur as a result of lost functional capacity.

c. Characteristics and processes that influence the function: describes the characteristics and processes of the wetland and the surrounding landscape that influence the function and lay the groundwork for the description of model variables.

d. Description of model variables: defines and discusses model variables and describes how each model variable is measured.

e. Functional capacity index: describes the assessment model from which the functional capacity index is derived and discusses how model variables interact to influence functional capacity. 


\section{Function 1: Surface and Subsurface Water Storage}

\section{Definition}

Surface and Subsurface Water Storage is defined as the presence of conditions that allow water source, storage, and outflow dynamics to occur in a manner typical of the three Everglades flats wetland subclasses. The function should be validated using a correlation of the FCI for this function with a hydrologic similarity index calculated for several Everglade wetland sites. The hydrologic similarity index compares season, depth, and frequency of inundation of assessed and reference standard sites (Davis and Ziewitz 1998).

\section{Rationale for selecting the function}

The capacity of the Everglades wetlands to store surface and subsurface water is critical to the integrity of the ecosystem. Wetland hydrology is probably the single most important determinant of the establishment and maintenance of specific types of wetlands and wetland processes (Mitsch and Gosselink 2000). Characteristic hydrologic, physical, chemical, and biotic processes are altered when the wetland hydrologic regime changes. Disruptions of the characteristic hydrologic regime of these wetlands has potential to alter, for example, the quality of water flowing through the Everglades and entering Florida Bay by

- Changing the period, season, and intensity of anaerobic conditions that drive many of the biogeochemical cycles.

- Creating conditions favorable for colonization of plants that are less efficient at retaining recycled nutrients.

- Altering characteristic concentrations of dissolved and suspended materials.

Alterations to the hydrologic regime modify the rate at which water moves between the surface water and groundwater, thereby affecting the groundwater level. Groundwater provides offsite baseflow, recharges the aquifer, and deters saltwater intrusion. In addition, the freshwater Everglades and estuarine Florida Bay ecosystem are closely linked by marine and freshwater hydrologic cycles and by organisms that depend on both systems during different times of the year or periods of their life cycles (McIvor, Ley, and Bjork 1994).

\section{Characteristics and processes that influence the function}

A characteristic hydrologic regime of a wetland is maintained by natural water inputs, storage, and outflow processes. A hydrologic regime is characterized as the depth, duration, frequency, and season of inundation. In the Florida Everglades, precipitation is the primary source of water. When rainfall occurs, it infiltrates the soil and the porous limestone, raising the water table. 
The water table continues to rise with continued rainfall until the soil surface becomes inundated. Often there is no clear distinction between groundwater and surface water other than the position of the ground surface relative to the water surface. Storage of water in the Everglades is relatively short term as water flows across a site and in the soil and is stored on the surface in solution holes and other microtopographic features. The depth and duration of surface water at a site is a function of the ground surface elevation (i.e., whether there has been excavation or fill). Evapotranspiration from plants and evaporation from open water surfaces is a significant source of water loss in the Everglades. Therefore, alterations in the characteristic distribution of plants can alter the amount of leaf surface for transpiration and the relative amount of open water for evaporation.

\section{Description of model variables}

Surface Soil Texture $\left(V_{\text {SURTEX }}\right)$. This variable is defined as the USDA soil texture of the surface horizon or layer of the soil. Soil is the medium on which and in which water is stored. Altering the texture of the soil through anthropogenic activities (e.g., fill, excavation, rock plowing) changes the capacity of water storage (Figure 5). This variable is determined with the following procedure.

(1) Estimate the texture class of the surface horizon using the feel method in or adjacent to each of the three $1-\mathrm{m}^{2}\left(3.3-\mathrm{ft}^{2}\right)$ sampling units, hereafter called subplots, placed in representative portions of each quadrant of a 0.04 -ha plot. The number of 0.04 -ha plots required to adequately characterize an area will depend on the size and heterogeneity of the site.

Chapter 5, "Assessment Protocol," provides guidance for determining the number and layout of sample points and sampling units. Appendix C describes the procedure for estimating texture by class using the feel method.

(2) Using Table 7 or Table 8, assign a score for each texture class found.

(3) Determine the subindex by averaging the scores from each of the subplots.

Soil texture in the Everglades ranged from marl or muck to gravel. Based on reference standard sites, textures were marl for Rocky and Marl Flats Wetlands sites and muck for Organic Flats Wetlands sites. Other USDA textural classes received categorically lower subindex scores down to zero for rock and pavement.

Soil Thickness ( $\left.\boldsymbol{V}_{\text {SоILтнICK }}\right)$. This variable represents the total thickness of the soil over limestone rock in the Rocky Flats Everglades wetlands. This variable is defined as the average soil thickness within multiple plots, exclusive of solution holes. The depth or thickness of soil in the Rocky Flats Everglades is shallow to very shallow. An increase in the average soil thickness indicates disturbances such as the addition of fill material or rock plowing. These impacts affect the natural water-holding capacity of the soil. 


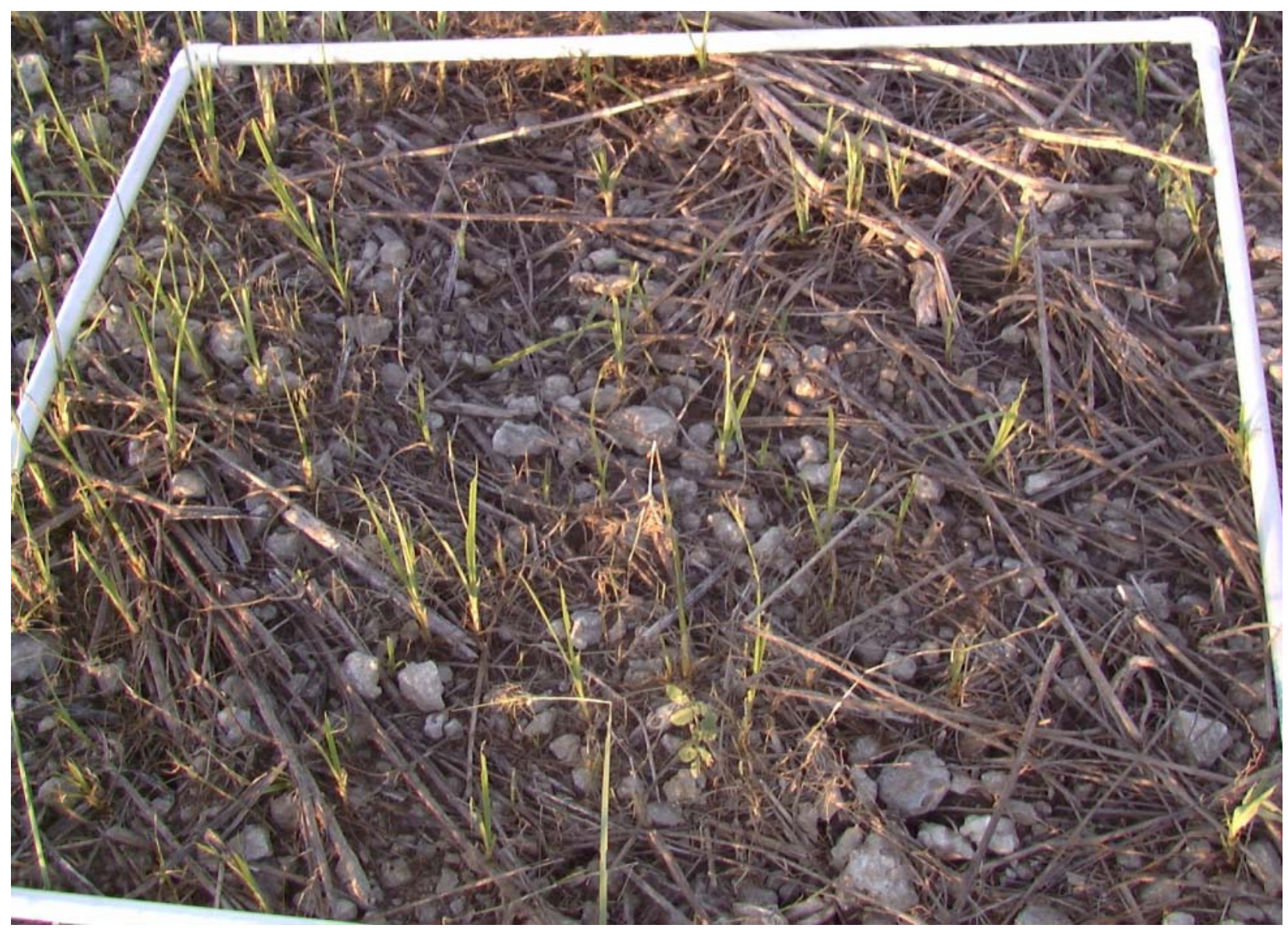

Figure 5. A very gravelly silt loam soil texture created by rock plowing on this Rocky Flats Everglades site

\begin{tabular}{|l|l||}
\hline \multicolumn{2}{|l||}{ Table 7} \\
Soil Surface Texture for Rocky and Marl Flats Everglades Wetlands \\
\hline \hline Soil Texture & Score \\
\hline \hline Marl $^{1}$ & 1.0 \\
\hline Muck $^{1}$ & 0.8 \\
\hline Silt & 0.9 \\
\hline Silt loam & 0.9 \\
\hline Loam & 0.5 \\
\hline Gravelly silt loam $(15 \%$ to $<35 \%$ gravel) & 0.4 \\
\hline Gravelly silt $(15 \%$ to $<35 \%$ gravel) & 0.4 \\
\hline Very gravelly silt loam $(35 \%$ to $<60 \%$ gravel) & 0.3 \\
\hline Very gravelly silt $(35 \%$ to $<60 \%$ gravel) & 0.3 \\
\hline Sandy loam & 0.2 \\
\hline Clay & 0.2 \\
\hline Sand & 0.2 \\
\hline Loamy sand & 0.2 \\
\hline Extremely gravelly silt loam $(60 \%$ to $<90 \%$ gravel) & 0.2 \\
\hline Extremely gravelly silt $(60 \%$ to $<90 \%$ gravel) & 0.2 \\
\hline Gravel ${ }^{1}(\geq 90 \%$ gravel) & 0.1 \\
\hline Rock & 0.0 \\
\hline Pavement ${ }^{1}$ & 0.0 \\
\hline \hline${ }^{1}$ Term used in lieu of texture. & \\
\hline & \\
\hline
\end{tabular}




\begin{tabular}{|l|l||}
\hline \multicolumn{2}{|l||}{ Table 8} \\
Soil Surface Texture for Organic Flats Everglades & Wetlands \\
\hline \hline Soil Texture & Score \\
\hline \hline Muck ${ }^{1}$ & 1.0 \\
\hline Marl ${ }^{1}$ & 0.8 \\
\hline Silt & 0.9 \\
\hline Silt loam & 0.9 \\
\hline Loam & 0.5 \\
\hline Gravelly silt loam $(15 \%$ to $<35 \%$ gravel) & 0.4 \\
\hline Gravelly silt $(15 \%$ to $<35 \%$ gravel) & 0.4 \\
\hline Very gravelly silt loam $(35 \%$ to $<60 \%$ gravel) & 0.3 \\
\hline Very gravelly silt $(35 \%$ to $<60 \%$ gravel) & 0.3 \\
\hline Sandy loam & 0.2 \\
\hline Clay & 0.2 \\
\hline Sand & 0.2 \\
\hline Loamy sand & 0.2 \\
\hline Extremely gravelly silt loam $(60 \%$ to $<90 \%$ gravel) & 0.2 \\
\hline Extremely gravelly silt $(60 \%$ to $<90 \%$ gravel) & 0.2 \\
\hline Gravel ${ }^{1}(\geq 90 \%$ gravel) & 0.1 \\
\hline Rock & 0.0 \\
\hline Pavement ${ }^{1}$ & 0.0 \\
\hline \hline${ }^{\prime}$ Term used in lieu of texture. & \\
\hline
\end{tabular}

Thickness of the soil is used to quantify this variable. Measure it using the following procedure:

(1) Measure the total marl soil depth to limestone outside of solution holes in each of three $1-\mathrm{m}^{2}\left(3.3-\mathrm{ft}^{2}\right)$ subplots.

(2) Average the thickness from all of the subplots.

(3) Report soil thickness in centimeters.

(4) Using Figure 6, determine the subindex score for soil thickness in Rocky Flats Everglades wetlands.

In the Everglades wetlands this variable is applicable only to the Rocky Flats Wetlands subclass. In the Everglades reference wetlands soil thickness ranged from 0 to $32 \mathrm{~cm}$. Based on data from reference standard wetlands sites, a variable subindex of 1.0 is assigned to sites with soil thickness between 3 and $7 \mathrm{~cm}$. As soil thickness decreases below $3 \mathrm{~cm}$ or increases above $7 \mathrm{~cm}$, a linearly decreasing subindex score down to zero is assigned. This is based on the assumption that the soil thickness is related to excavation or filling activities to the point that the site is no longer inundated or saturated under normal conditions. These assumptions could be validated using the independent, quantitative measures of function defined in the previous paragraph.

Microtopographic Features $\left(V_{\text {MICRo }}\right)$. This variable represents the occurrence of microtopographic features in the Everglades wetland ecosystem. Microtopographic features are defined as small topographic changes in elevation, often less than $1 \mathrm{~cm}$, over short distances, usually less than $1 \mathrm{~m}$. Altering the microtopographic features of the landscape through anthropogenic activities (e.g., 


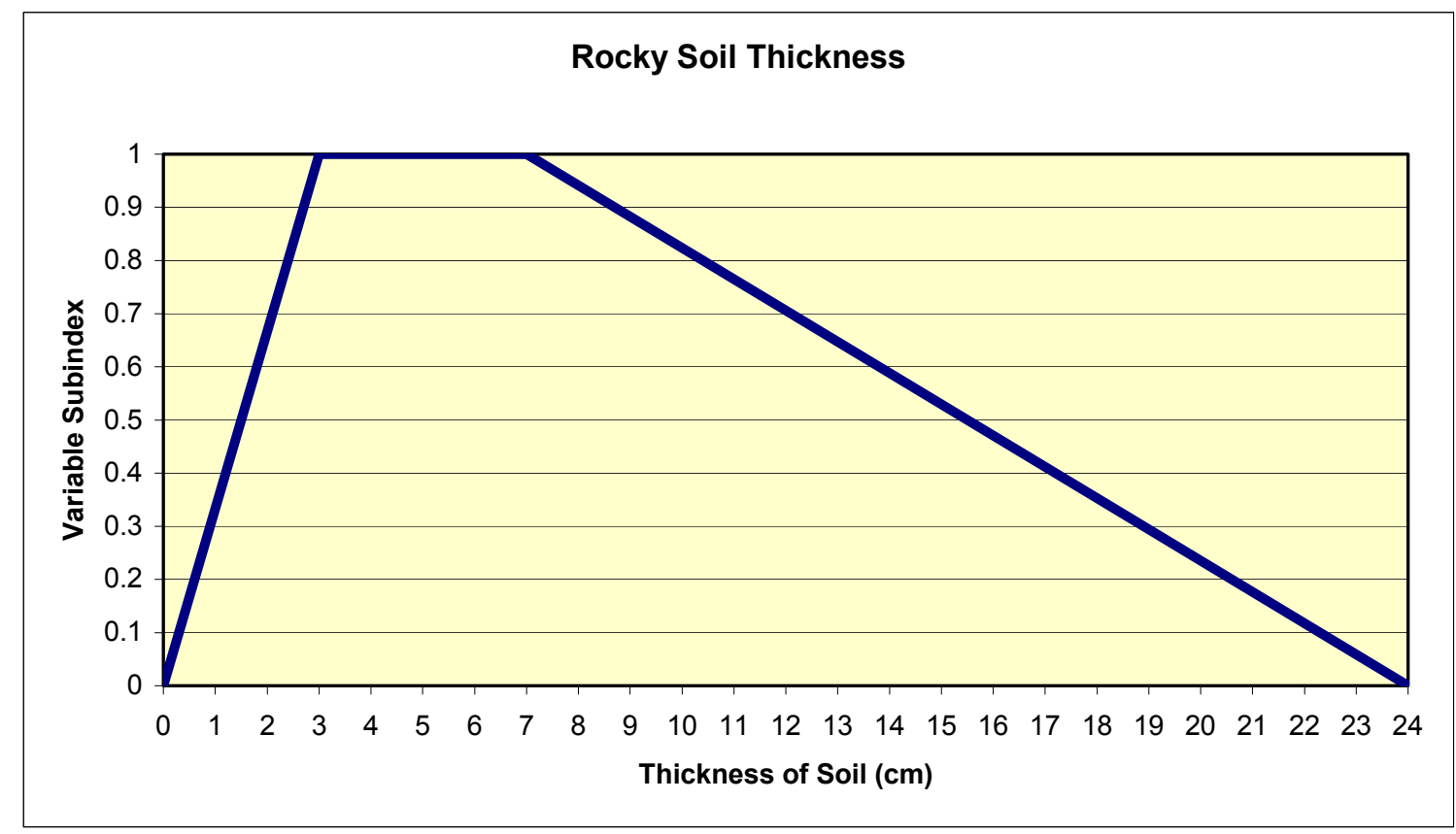

Figure 6. Relationship between soil thickness and functional capacity

fill, excavation, rock plowing, land leveling, bedding) changes the water storage capability of the soil. This variable is determined with the following procedure:

(1) Determine if any of the Wetland Assessment Area (WAA) or Partial Wetland Assessment Area (PWAA) has been altered by bedding, rock plowing, land leveling, or other activity that has altered the microtopographic features.

(2) If no altered areas exist, assign a value of 1.0. This indicates that the microtopography in the assessment area is similar to reference standard sites.

(3) If areas with altered microtopography exist, determine what percent of the area has been altered. Using Table 9, assign a subindex score for each alteration found.

(4) Report the percent of the WAA or PWAA with altered microtopography.

(5) Using a weighted average of the subindex score and percent area of each microtopographic feature condition, determine the subindex score for the WAA or PWAA. 


\begin{tabular}{|l|l||}
\hline \multicolumn{2}{|l||}{\begin{tabular}{l|} 
Table 9 \\
Microtopographic Features
\end{tabular}} \\
\hline \hline Alteration Category & Variable Subindex \\
\hline \hline Rock plowing & 0.0 \\
\hline Land leveling & 0.1 \\
\hline Bedding & 0.2 \\
\hline Unaltered & 1.0 \\
\hline
\end{tabular}

Microtopographic features in the Everglades were either 0 or 100 percent. The most significant topographic change in the Rocky Flats Wetland subclass is rock plowing. This mechanical scarifying of the landscape to create a soil deep enough to plant crops drastically alters the microtopographic features of this subclass to the point that restoration of this variable is impossible. In the Marl Flats Wetland subclass, land leveling and bedding are the most significant impacts on microtopographic features. However, the effects are completely opposite. Land leveling is the alteration of the landscape to remove the microtopographic features to improve surface drainage. Bedding is the practice of mounding the soil in rows to raise the root zone above the water table (Figure 7). This practice is usually used for ornamental nursery stock or fruit trees in the Marl Flats Wetland subclass. Unlike rock plowing, the site microtopographic features could be returned to some resemblance of predisturbance condition for areas that have been land-leveled or bedded. The Organic Flats Wetland subclass is most impacted by land leveling from the standpoint of microtopographic features. Restoration potential would be similar to Marl Flats Wetland sites for this variable.

Cover of Woody Vegetation $\left(V_{W O O D Y}\right)$. This variable is defined as the average aerial cover of leaves and stems of shrubs and trees combined, or woody vegetation. It is assessed as the average percent cover of woody plants $\geq 1 \mathrm{~m}$ (3.3 ft) tall within multiple subplots, excluding vines.

Percent cover of woody vegetation is used to quantify this variable. Measure it using the following procedure:

(1) Visually estimate the percent of the ground surface that is covered by woody vegetation by mentally projecting the leaves and stems to the ground surface in each $11.3-\mathrm{m}$ (37.2-ft) radius sampling unit, hereafter called plots, placed in representative portions of each WAA or PWAA. The number of plots required to adequately characterize an area will depend on the size and heterogeneity of the site. Chapter 5, "Assessment Protocol," provides guidance for determining the number and layout of sample points and sampling units.

(2) Average the percent woody cover from all of the plots.

(3) Report woody vegetation cover as a percent between 0 and 100 .

(4) Using Figure 8, determine the subindex score for woody vegetation. 


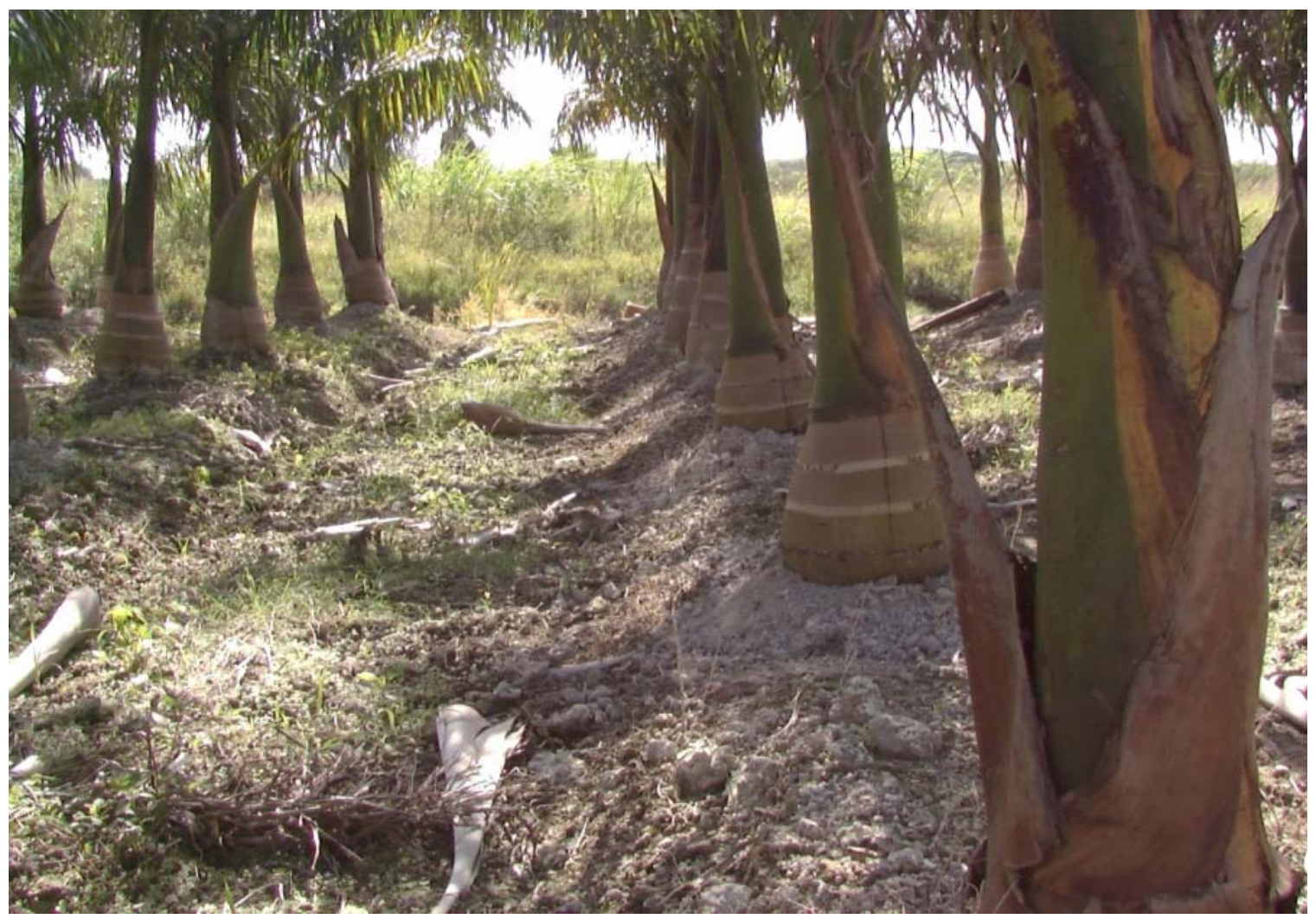

Figure 7. Microtopography altered by bedding for nursery stock

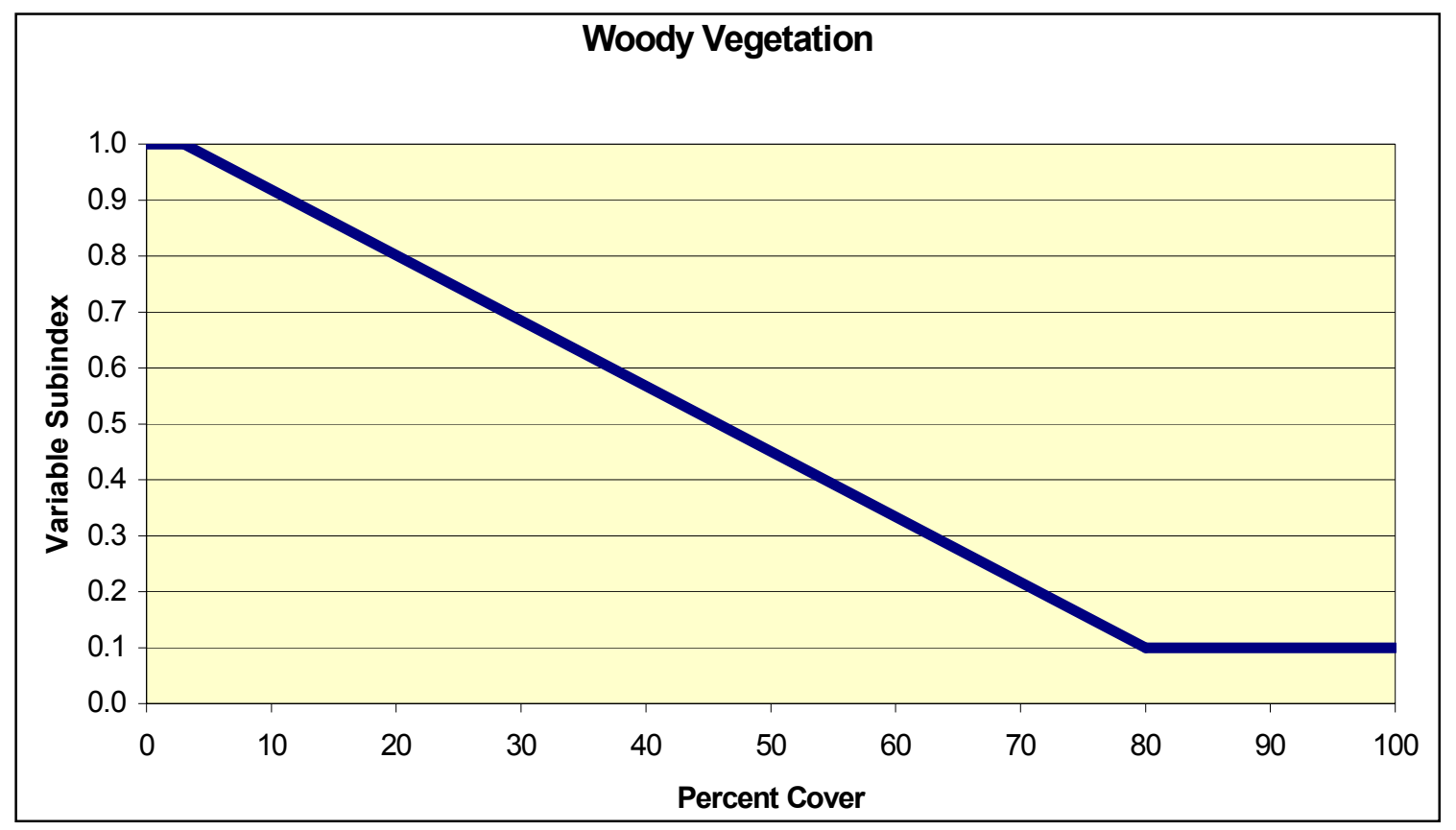

Figure 8. Relationship between woody vegetation and functional capacity 
Shrub and tree cover data were combined because independent analysis of the data for both cover types showed similar relationships. In the Everglades reference sites, percent cover of woody vegetation ranged from 0 to 35 percent. Based on data from reference standard wetland sites, woody vegetative cover is between 0 and 3 percent for Rocky, Marl, and Organic Flats wetlands. As percent cover of woody vegetation increases above 3 percent, a linearly decreasing subindex score down to 0.1 is assigned for wetlands at 80 to 100 percent cover of woody vegetation. This is based on the assumption that the increase in woody vegetation cover indicates increased levels of evapotranspiration (Figure 9). The rate at which the subindex decreases and the selection of 0.1 as the variable subindex end point at 80 to 100 percent cover are based on the assumption that the relationship between percent cover of woody vegetation and increase in evaporation is linear. It is also assumed that if woody cover reached 80 to 100 percent, evapotranspiration would not prevent the site from being inundated during most years, but would reduce the duration of inundation. These assumptions could be validated using the independent, quantitative measure of function described in the preceding paragraph.

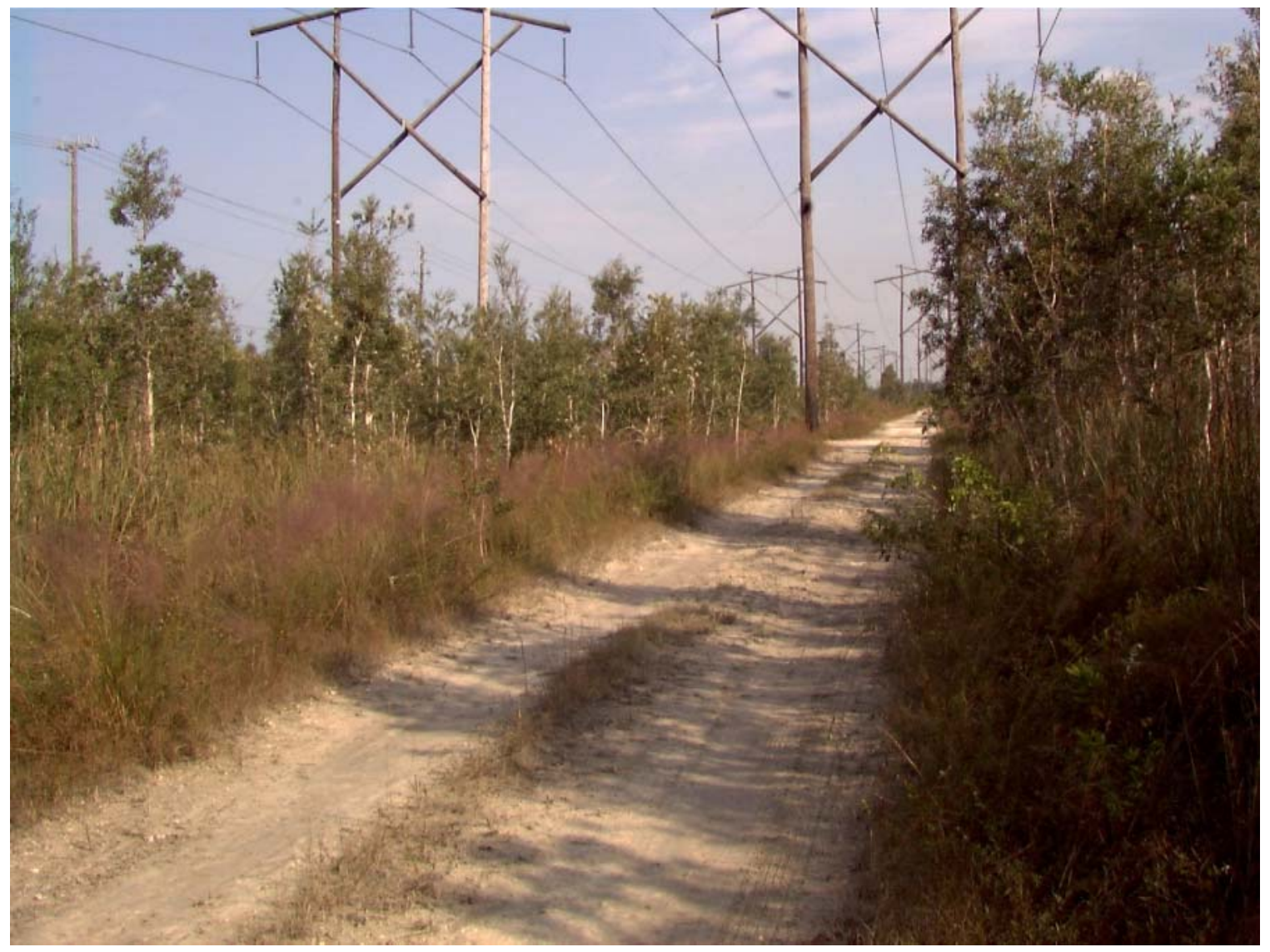

Figure 9. Woody vegetation cover 
Periphyton Cover $\left(V_{P E R I}\right)$. This variable which represents the total cover of periphyton in the wetland, is defined as the average percent cover of periphyton within multiple plots. It is used as a measure for Rocky and Marl Flats Everglades subclasses only.

Percent cover of periphyton is used to quantify this variable. Measure it using the following procedure:

(1) Visually estimate the percentage of the ground surface that is covered by emergent periphyton in each of three $1-\mathrm{m}^{2}\left(3.3-\mathrm{ft}^{2}\right)$ subplots.

(2) Average the percent cover from all of the subplots.

(3) Report periphyton cover as a percent.

(4) Using Figure 10 for Rocky Flats or Figure 11 for Marl Flats Everglades wetlands, determine the subindex score for the percent cover of periphyton.

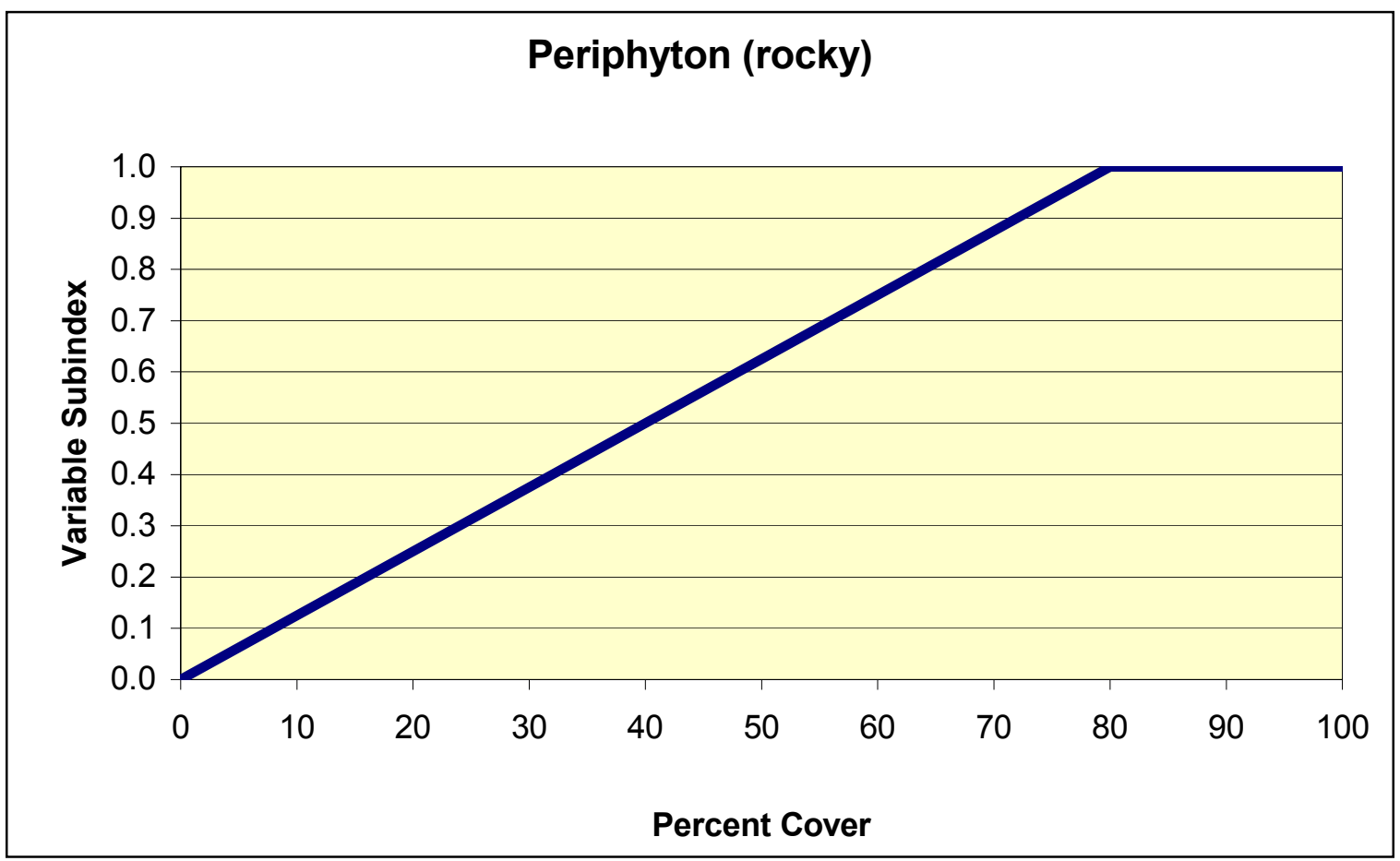

Figure 10. Relationship between periphyton and functional capacity for Rocky Flats Everglades wetlands 


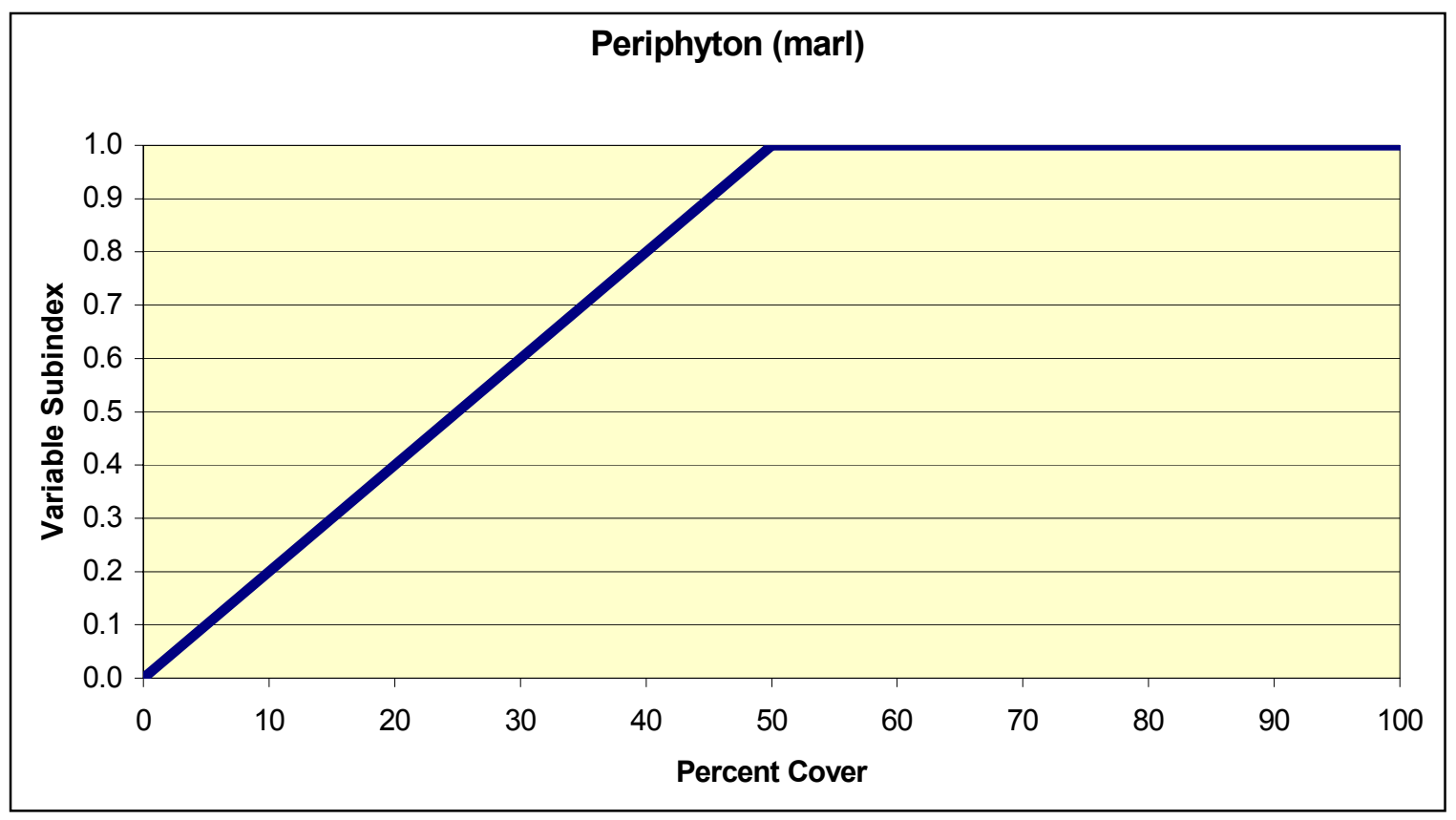

Figure 11. Relationship between periphyton and functional capacity for Marl Flats Everglades wetlands

In the Everglades this variable is applicable only to the Rocky and Marl Flats Everglades subclasses. In the Everglades reference wetlands, periphyton cover ranged from 0 to 96 percent for both Rocky and Marl Flats wetlands (Figure 12). Based on data from reference standard wetlands sites, a variable subindex of 1.0 is assigned to sites with periphyton cover between 80 and 100 percent for Rocky Flats Wetlands and between 50 and 100 percent for Marl Flats wetlands. Zero percent cover of periphyton indicates severely altered conditions. As percent cover of periphyton decreases below 80 percent for Rocky Flats sites and 50 percent for Marl Flats sites, a linearly decreasing subindex score down to zero is assigned for rocky and Marl Flats sites at zero percent cover of periphyton. This is based on the assumption that the decrease in periphyton cover indicates altered hydrology or disturbance (e.g., plowing) or both. The rate at which the subindex decreases and the selection of zero as variable subindex end point at 0 percent cover are based on the assumption that the relationship between percent cover of periphyton and altered hydrology is linear. These assumptions could be validated using the independent, quantitative measures of function defined in the previous paragraph.

\section{Functional capacity index}

The assessment model for calculating the FCI is as follows: 


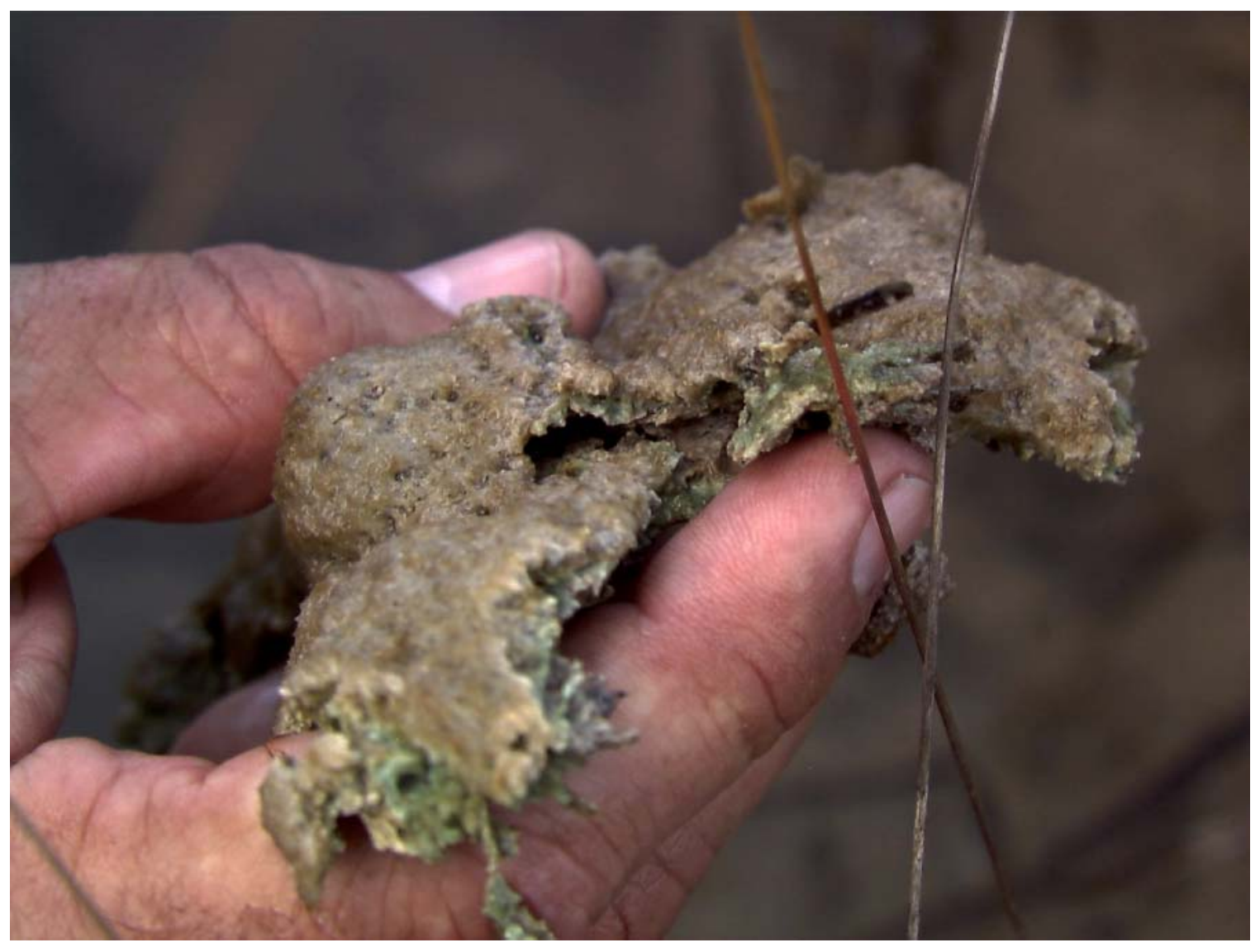

Figure 12. Periphyton, found on all reference standard sites in the Rocky and Marl Flats Everglades wetlands

a. For Rocky Flats wetlands of the Florida Everglades:

$$
F C I=\left[\frac{V_{\text {SURTEX }}+V_{\text {SOILTHICK }}+V_{\text {MICRO }}+\left(\frac{V_{\text {WOODY }}+V_{\text {PERI }}}{2}\right)}{4}\right]
$$

b. For Marl Flats wetlands of the Florida Everglades:

$$
F C I=\left[\frac{V_{\text {SURTEX }}+V_{\text {MICRO }}+\left(\frac{V_{\text {WOODY }}+V_{\text {PERI }}}{2}\right)}{3}\right]
$$


c. For Organic Flats wetlands of the Florida Everglades:

$$
F C I=\left(\frac{V_{\text {SURTEX }}+V_{\text {MICRO }}+V_{\text {WOODY }}}{3}\right)
$$

In the models, the capacity of the Everglades wetlands to maintain surface and subsurface hydrology focuses on three characteristics. The first is the effect of the soil to hold water $\left(V_{\text {SURTEX }}\right)$ and alteration of this capacity by excavation or fill activities. The second is the microtopographic depressional features $\left(V_{\text {MICRO }}\right)$ that trap and hold pockets of water for longer periods of time than the surrounding microtopographic highs. The third is the effect that woody vegetation $\left(V_{W O O D Y}\right)$ has on evapotranspiration. Trees use more water than the native herbaceous vegetation that dominates these wetland subclasses (Lodge 1994).

The percent cover of periphyton $\left(V_{P E R I}\right)$ is used as an indicator in Rocky and Marl Flats Wetlands subclasses that the hydrology is present because periphyton will not grow if the site is not inundated. $V_{W O O D Y}$ and $V_{P E R I}$ are generally related by the condition that if the percent cover of woody vegetation is high (resulting in a low variable subindex score), then percent cover of periphyton is low (resulting in a low variable subindex score). These two variables are averaged to prevent overweighting the significance of the other variables. All other variables are averaged together because it is not clear that any variable is more important from the standpoint of water storage.

The most obvious impacts to the Everglades ecosystem are the numerous ditches and canals that have been constructed to provide drainage to the system. The South Florida Water Management District controls this system of ditches. Much of the water that flows into or out of a particular area is controlled by this system of ditches and canals. Because of this control, it has been impossible to evaluate the effect of the ditches or canals in a rapid assessment procedure. Also what appears to be barriers to surface water flow (e.g. roads, berms, levees) could not be shown to pond water behind them or dry the downslope side. For these reasons, these features were not addressed in this model.

\section{Function 2: Biogeochemical Processes}

\section{Definition}

The function is defined as the characteristic biotic and abiotic processes of the Everglades wetlands that alter concentrations of imported nutrients and compounds in the water leaving the wetland in comparison with water entering the wetland. These processes include conversion of nutrients and other elements and compounds from one form into another by assimilation into plant biomass, remineralization of those materials when the plant materials decompose, longterm storage of nutrients and compounds in mineral and organic soil fractions, and oxygen production. The function can be validated using correlation of the function FCI with the differences in amounts of dissolved nutrients and compounds (tons per hectare per year) in inflowing and outflowing water to and from the assessed wetland. 


\section{Rationale for selecting the function}

This function assesses conditions affecting the efficiency of wetland processes in the Everglades to cycle nutrients and compounds and consequently the nutrient and compound loading of receiving water bodies. As a naturally oligotrophic system, the limited nutrients are tightly held in plants and soils of the Everglades, and nutrients are efficiently recycled as plant material decomposes. In addition, the quality of water passing through these wetlands is often improved due to removal of suspended and dissolved materials. The imported materials can be trapped in the soil or converted abiotically to nontoxic forms that are removed from the food web. There is naturally little loss of nutrients to receiving waters; however, alterations to the ecosystem can result in less tightly linked, less efficient cycles of nutrients and compounds within the wetland, and altered water quality.

The impact on nutrient and compound loading to Florida Bay is of great concern in the state and is part of the overall Everglades Restoration Project. Inputs of phosphorus into the Florida Everglades are cause for particular concern because of the potential to shift the natural oligotrophic ecosystem relationships. The Everglades ecosystem evolved under conditions of relatively low phosphorus inputs, mostly from direct rainfall. Changes in land use that result in increased inputs of nutrients and compounds into the Everglades have the potential to alter the composition of and relationships among the biota and their efficiency at nutrient cycling.

\section{Characteristics and processes that influence the function}

Biogeochemical cycling of nutrients and compounds is a function of biotic and abiotic processes that result from conditions within and around the wetland. Biotic processes are based primarily on the vegetation that incorporates nutrients in biomass (Mitsch and Gosselink 2000). The plant composition and distribution affect the amounts and types of nutrients that are incorporated into the biomass, as well as the rate at which the nutrients are mineralized when the vegetation decays. Plants also provide resistance to flowing water and increase sedimentation, thereby improving water quality. While microbial activity is extremely important in nutrient cycling, the measurement is beyond the scope of a rapid assessment.

Abiotic processes affecting retention and removal of nutrients and compounds are dependent primarily on the adsorption of materials to soils, the amount of water that passes through the wetland carrying dissolved materials, the hydroperiod to maintain anaerobic conditions and retention time, and importation of materials from surrounding areas (Beaulac and Reckhow 1982; Federico 1977; Grubb and Ryder 1972; Ostry 1982; Shahan 1982; Strecker et al. 1992; Zarbock et al. 1994). Natural soils, hydrology, and vegetation are important factors in maintaining these characteristic processes.

Water acts as a barrier to oxygen diffusion into the soil, which determines the type of organisms that can survive as well as the solubility of nutrients and 
compounds (Mitsch and Gosselink 2000). Characteristic surface water flow, depth, and hydroperiod are the principal hydrologic factors that determine the amount of oxygen in wetland soils. Alterations in wetland hydrology often lead to changes in characteristic biota to species that are more tolerant of the new conditions. Nutrients and compounds are often more soluble under anaerobic conditions, and increases in the depth or duration of water on a site result in increased leaching rates and losses to downstream ecosystems.

\section{Description of model variables}

Surface Soil Texture $\left(V_{\text {SURTEX }}\right)$. This variable is defined as the USDA soil texture of the surface horizon or layer of the soil. Soil is the medium on which and in which water is stored. Altering the texture of the soil through anthropogenic activities (e.g., fill, excavation, rock plowing) changes the capacity of water storage. This variable is determined with the following procedure.

(1) Estimate the texture class of the surface horizon using the feel method in or adjacent to each of the three $1-\mathrm{m}^{2}\left(3.3-\mathrm{ft}^{2}\right)$ subplots. Appendix $\mathrm{C}$ describes the feel method for estimating texture by class.

(2) Using Table 10 or Table 11, assign a score for each texture class found.

(3) Determine the subindex score by averaging all of the scores.

Soil texture in the Everglades ranged from marl or muck to gravel. Based on reference standard sites, textures were marl for Rocky and Marl Flats wetlands sites and muck for Organic Flats wetlands sites. Other USDA textural classes received categorically lower subindex scores down to zero for bedrock and pavement (Figure 13).

\begin{tabular}{|l|l||}
\hline $\begin{array}{l}\text { Table } 10 \\
\text { Soil Surface Texture for Rocky and Marl Flats Everglades Wetlands }\end{array}$ \\
\hline \hline Soil Texture & Score \\
\hline \hline Marl $^{1}$ & 1.0 \\
\hline Muck $^{1}$ & 0.8 \\
\hline Silt & 0.9 \\
\hline Silt loam & 0.9 \\
\hline Loam & 0.5 \\
\hline Gravelly silt loam $(15 \%$ to $<35 \%$ gravel) & 0.4 \\
\hline Gravelly silt $(15 \%$ to $<35 \%$ gravel) & 0.4 \\
\hline Very gravelly silt loam $(35 \%$ to $<60 \%$ gravel) & 0.3 \\
\hline Very gravelly silt $(35 \%$ to $<60 \%$ gravel) & 0.3 \\
\hline Sandy loam & 0.2 \\
\hline Clay & 0.2 \\
\hline Sand & 0.2 \\
\hline Loamy sand & 0.2 \\
\hline Extremely gravelly silt loam $(60 \%$ to $<90 \%$ gravel) & 0.2 \\
\hline Extremely gravelly silt $(60 \%$ to $<90 \%$ gravel) & 0.2 \\
\hline Gravel ${ }^{\prime}(\geq 90 \%$ gravel) & 0.1 \\
\hline Bedrock & 0.0 \\
\hline Pavement ${ }^{1}$ & 0.0 \\
\hline \hline${ }^{1}$ Term used in lieu of texture. & \\
\hline & \\
\hline
\end{tabular}




\begin{tabular}{|c|c|}
\hline \multicolumn{2}{|c|}{$\begin{array}{l}\text { Table } 11 \\
\text { Soil Surface Texture for Organic Flats Everglades Wetlands }\end{array}$} \\
\hline Soil Texture & Score \\
\hline Muck ${ }^{1}$ & 1.0 \\
\hline $\mathrm{Marl}^{1}$ & 0.8 \\
\hline Silt & 0.9 \\
\hline Silt loam & 0.9 \\
\hline Loam & 0.5 \\
\hline Gravelly silt loam ( $15 \%$ to $<35 \%$ gravel) & 0.4 \\
\hline Gravelly silt ( $15 \%$ to $<35 \%$ gravel) & 0.4 \\
\hline Very gravelly silt loam $(35 \%$ to $<60 \%$ gravel) & 0.3 \\
\hline Very gravelly silt $(35 \%$ to $<60 \%$ gravel) & 0.3 \\
\hline Sandy loam & 0.2 \\
\hline Clay & 0.2 \\
\hline Sand & 0.2 \\
\hline Loamy sand & 0.2 \\
\hline Extremely gravelly silt loam $(60 \%$ to $<90 \%$ gravel) & 0.2 \\
\hline Extremely gravelly silt $(60 \%$ to $<90 \%$ gravel) & 0.2 \\
\hline Gravel' $^{\prime}(\geq 90 \%$ gravel) & 0.1 \\
\hline Bedrock & 0.0 \\
\hline Pavement $^{1}$ & 0.0 \\
\hline
\end{tabular}

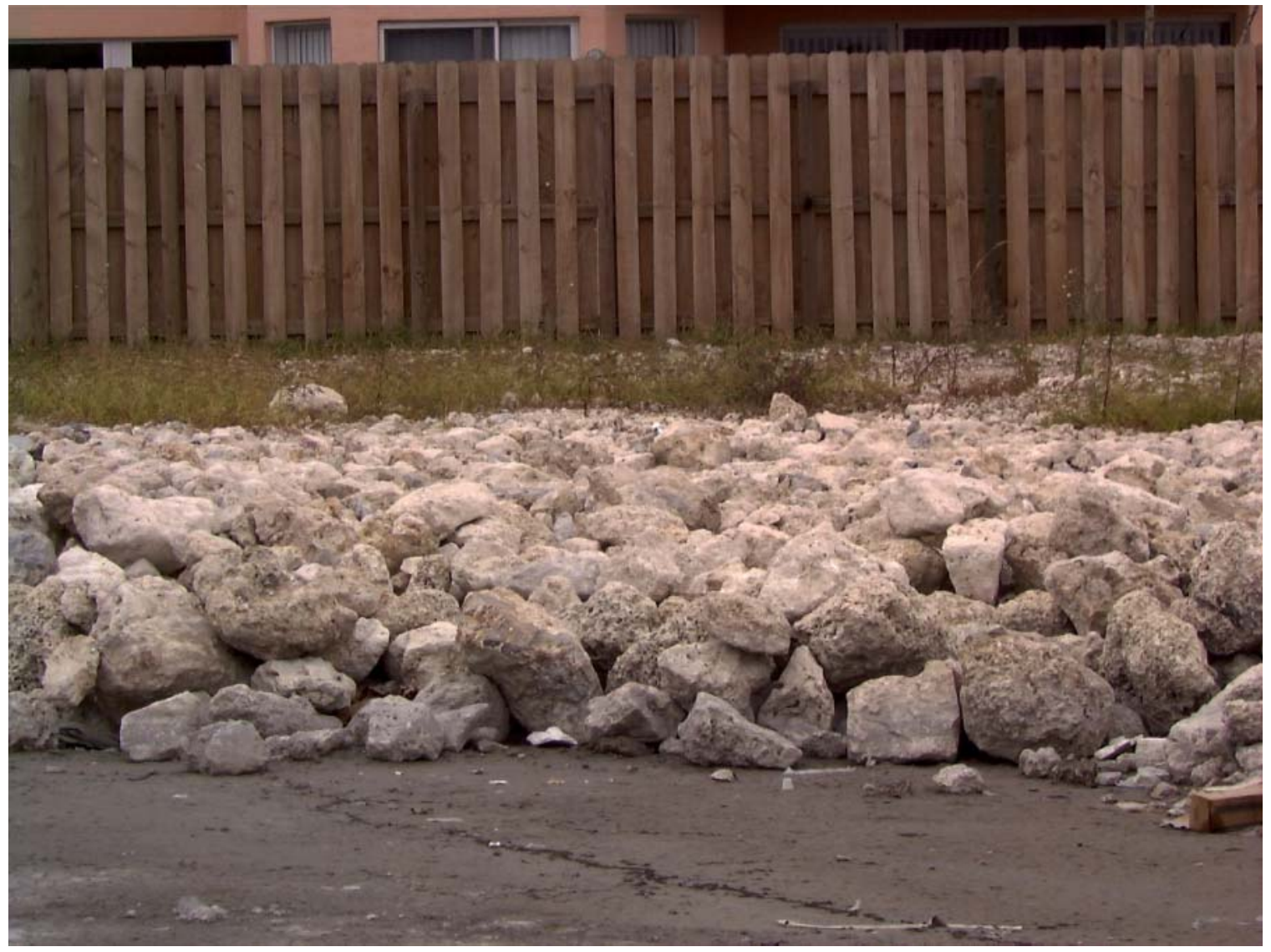

Figure 13. Limestone gravel used as fill material 
Microtopographic Features $\left(V_{\text {MICRo }}\right)$. This variable represents the occurrence of microtopographic features in the Everglades wetland ecosystem. Microtopographic features are defined as small topographic changes in elevation, often less than $1 \mathrm{~cm}$, over short distances, usually less than $1 \mathrm{~m}$. Altering the microtopographic features of the landscape through anthropogenic activities (e.g., fill, excavation, rock plowing, land leveling, bedding) changes the water storage capability of the soil. This variable is determined with the following procedure:

(1) Determine if any of the WAA or PWAA has been altered by bedding, rock plowing, land leveling, or other activity that has altered the microtopographic features.

(2) If no altered areas exist, assign a value of 1.0. This indicates that the microtopography in the assessment area is similar to reference standard sites.

(3) If areas with altered microtopography exist, determine what percent of the area has been altered. Using Table 12, assign a subindex score for each alteration found.

(4) Report the percent of the WAA or PWAA with altered microtopography.

(5) Using a weighted average of the subindex score and percent area of each microtopographic feature condition, determine the subindex score for the WAA or PWAA.

\begin{tabular}{|l|l||}
\hline \hline \multicolumn{2}{|l|}{$\begin{array}{l}\text { Table } 12 \\
\text { Microtopographic Features }\end{array}$} \\
\hline \hline Alteration Category & Variable Subindex \\
\hline \hline Rock plowing & 0.0 \\
\hline Land leveling & 0.1 \\
\hline Bedding & 0.2 \\
\hline Unaltered & 1.0 \\
\hline \hline
\end{tabular}

Microtopographic features in the Everglades ranged from 0 to 100 percent. The most significant topographic change in the Rocky Flats subclass is rock plowing (Figure 14). This mechanical scarifying of the landscape to create a soil deep enough to plant crops drastically alters the microtopographic features of this subclass to the point that it is impossible to restore this variable. In the Marl Flats wetlands subclass, land leveling and bedding are the most significant impacts on microtopographic features. However, the effects are completely opposite. Land leveling is the alteration of the landscape to remove the microtopographic features to improve surface drainage. Bedding is the practice of mounding the soil in rows to raise the root zone above the water table. This practice is usually used for ornamental nursery stock of fruit trees in the Marl Flats wetlands subclass. Unlike rock plowing, the site microtopographic features could be returned to some resemblance of predisturbance condition. The Organic Flats wetlands subclass is most impacted by land leveling from the standpoint of microtopographic features. Restoration potential would be similar to Marl Flats wetlands sites for this variable. 


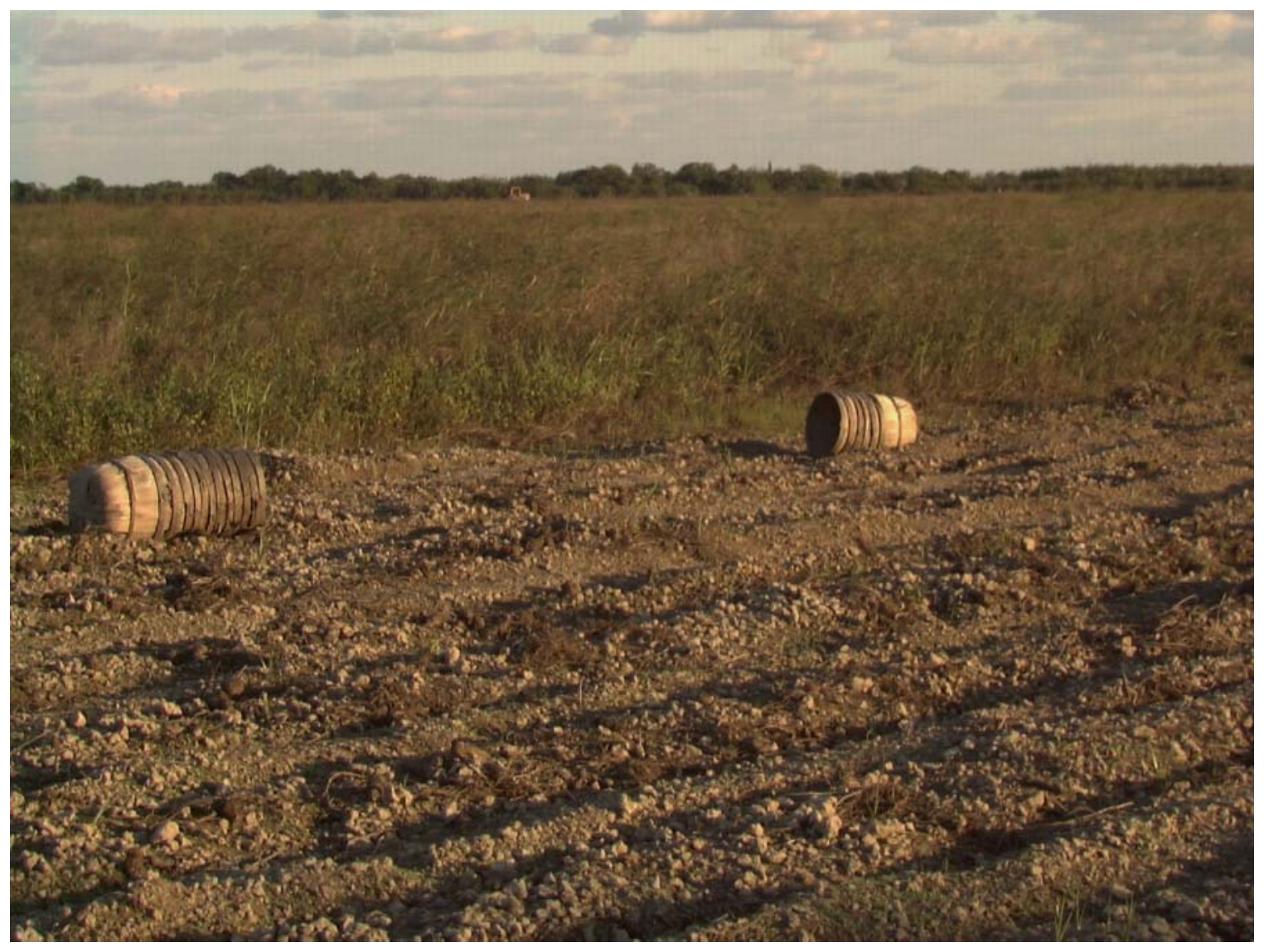

Figure 14. Natural microtopography destroyed by rock plowing

Emergent Macrophytic Vegetation Cover $\left(V_{M A C}\right)$. This variable represents the total cover of macrophytic vegetation in the wetland. This variable is defined as the average percent cover of emergent macrophytic vegetation $<1 \mathrm{~m}(3.3 \mathrm{ft})$ in height within multiple subplots, exclusive of periphyton.

Percent cover of emergent macrophytic vegetation is used to quantify this variable. Measure it using the following procedure:

(1) Visually estimate the percentage of the ground surface covered by emergent macrophytic vegetation by mentally projecting the leaves and stems to the ground surface in each of three $1-\mathrm{m}^{2}\left(3.3-\mathrm{ft}^{2}\right)$ subplots.

(2) Average the percent cover from all of the subplots.

(3) Report emergent macrophytic vegetation cover as a percent between 0 and 100 .

(4) Using Figure 15 for Rocky Flats, Figure 16 for Marl Flats, or Figure 17 for Organic Flats Everglades wetlands, determine the subindex score for percent cover of macrophytic vegetation. 


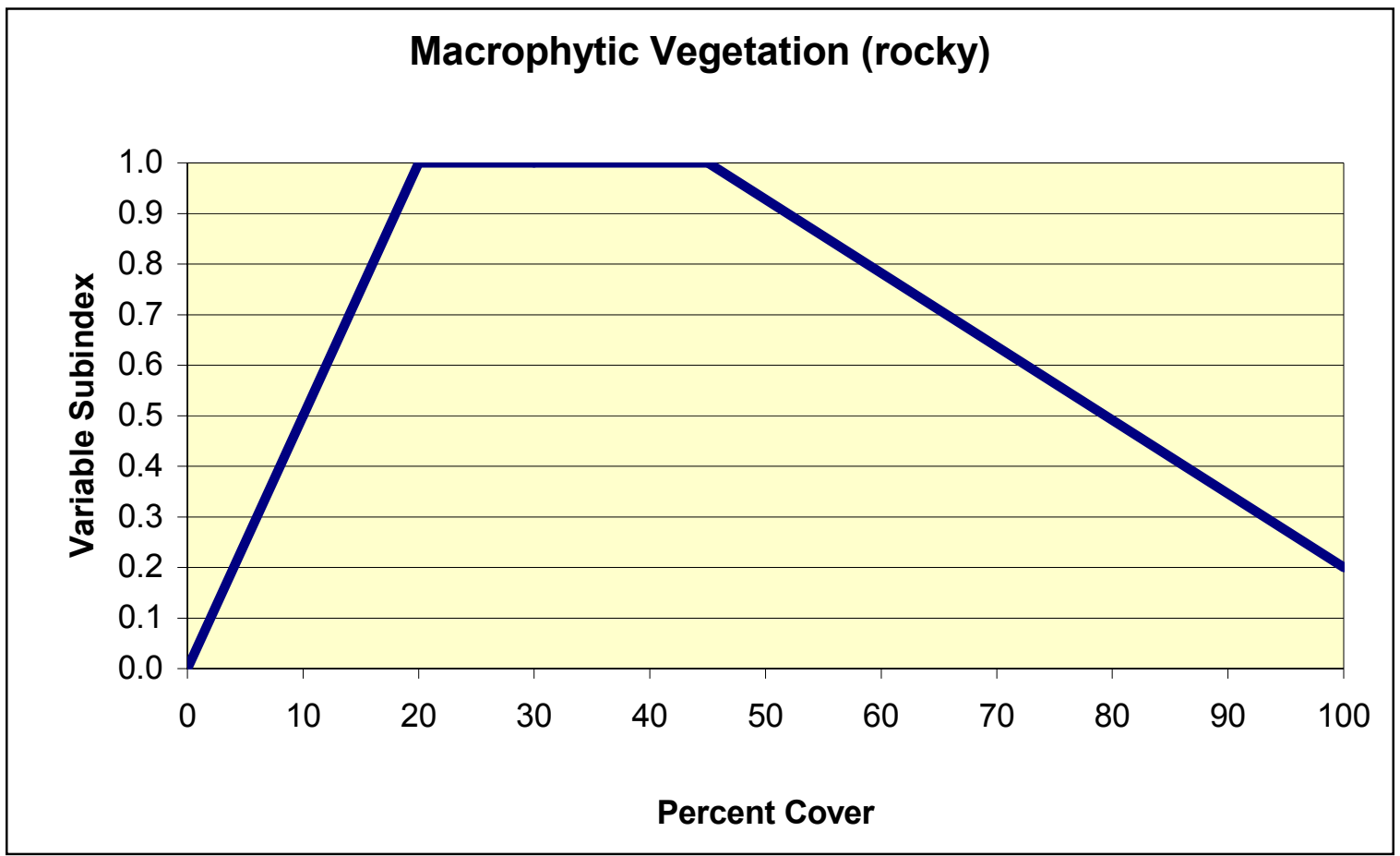

Figure 15. Relationship between macrophytic vegetation and functional capacity for Rocky Flats Everglades wetlands

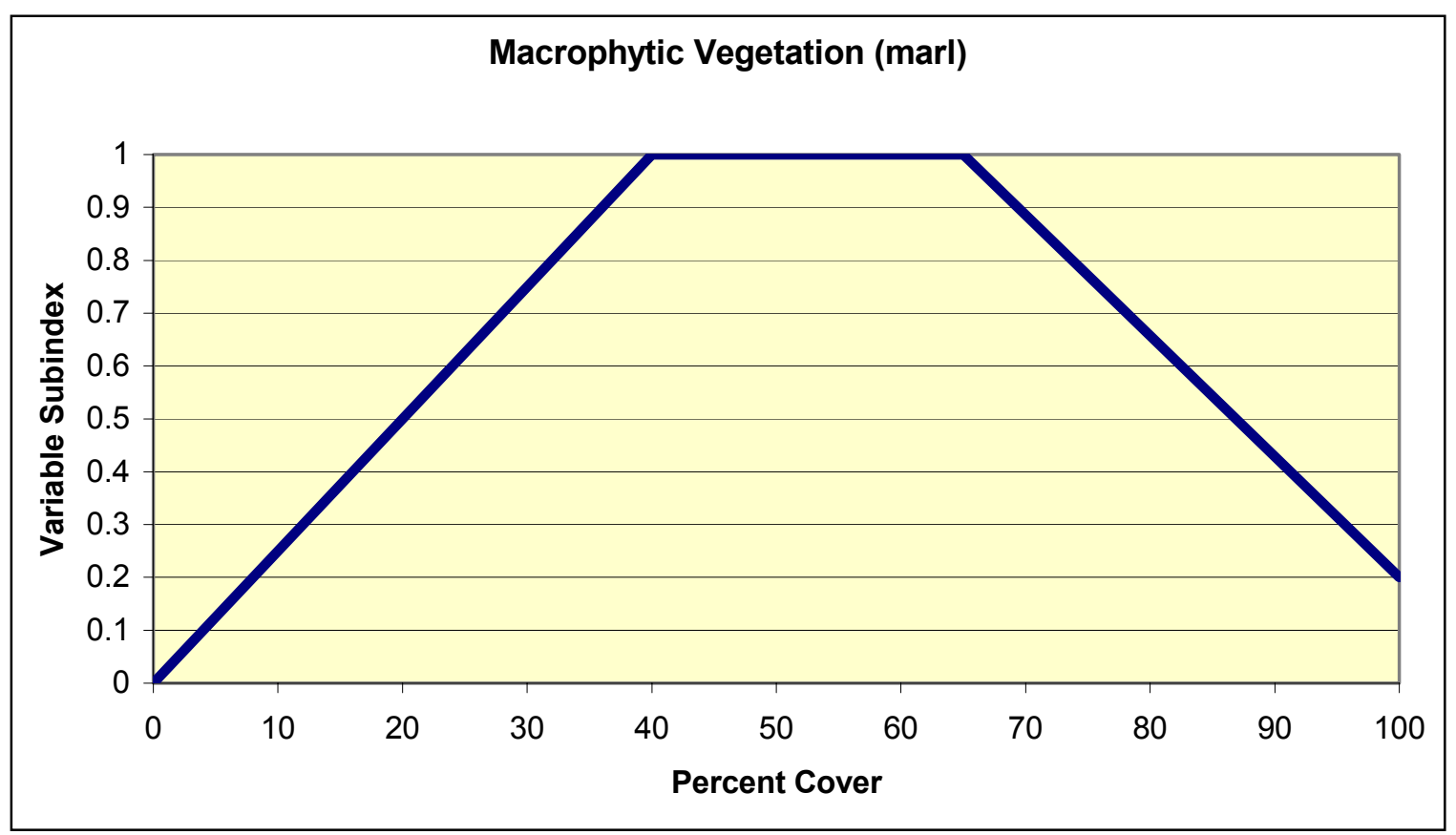

Figure 16. Relationship between macrophytic vegetation and functional capacity for Marl Flats Everglades wetlands 


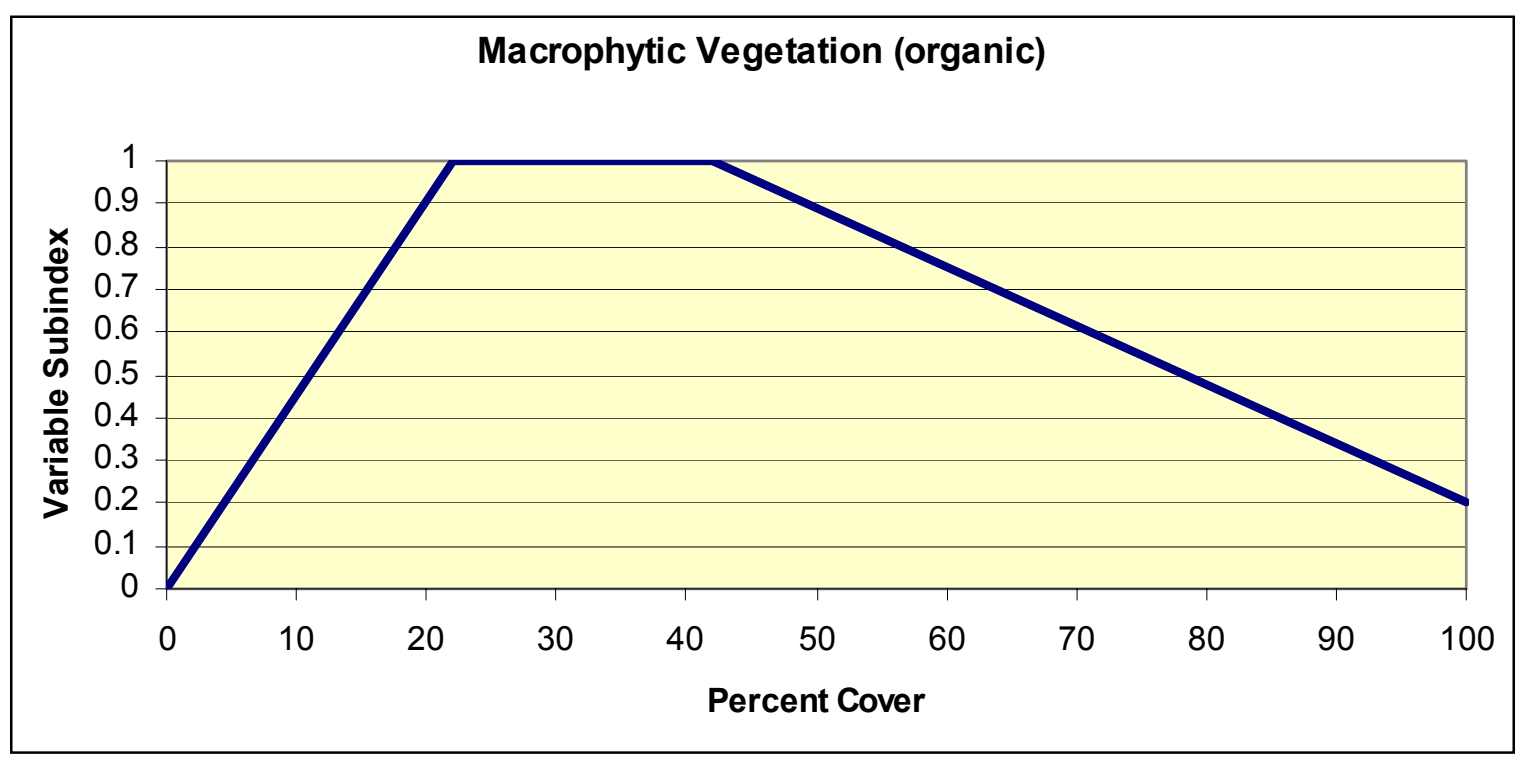

Figure 17. Relationship between macrophytic vegetation and functional capacity for Organic Flats Everglades wetlands

In the Everglades reference wetlands, emergent macrophytic vegetation cover ranged from 2 to 90 percent for Rocky Flats wetlands, 12 to 98 percent for Marl Flats wetlands, and 3 to 98 percent for Organic Flats wetlands. Based on data from reference standard wetlands sites, a variable subindex of 1.0 is assigned to sites with emergent macrophytic vegetative cover between 20 and 45 percent for Rocky Flats wetlands (Figure 18), 40 to 65 percent for Marl Flats wetlands, and 22 to 42 percent for Organic Flats wetlands. Zero percent cover of macrophytic vegetation, while not measured, would indicate severely altered conditions. As percent cover of emergent macrophytic vegetation increases above 45 percent for Rocky Flats sites, 65 percent for Marl Flats sites, and 42 percent for Organic Flats sites, a linearly decreasing subindex score down to 0.2 is assigned for Rocky, Marl, and Organic Flats sites at 100 percent cover of emergent macrophytic vegetation. This is based on the assumption that the increase in emergent macrophytic vegetation cover indicates unnatural levels of productivity such as following fertilization. The rate at which the subindex decreases and the selection of 0.2 as the variable subindex end points at 100 percent cover are based on the assumption that the relationship between percent cover of emergent macrophytic vegetation and nutrient cycling is linear and that emergent macrophytic vegetation is contributing to nutrient cycling even when percent cover is high. These assumptions could be validated using the independent, quantitative measures of function defined in the preceding paragraph.

Periphyton Cover $\left(V_{P E R I}\right)$. This variable, which represents the total cover of periphyton in the wetland, is defined as the average percent cover of periphyton within multiple subplots. It applies only to Rocky and Marl Flats Everglades wetlands. 


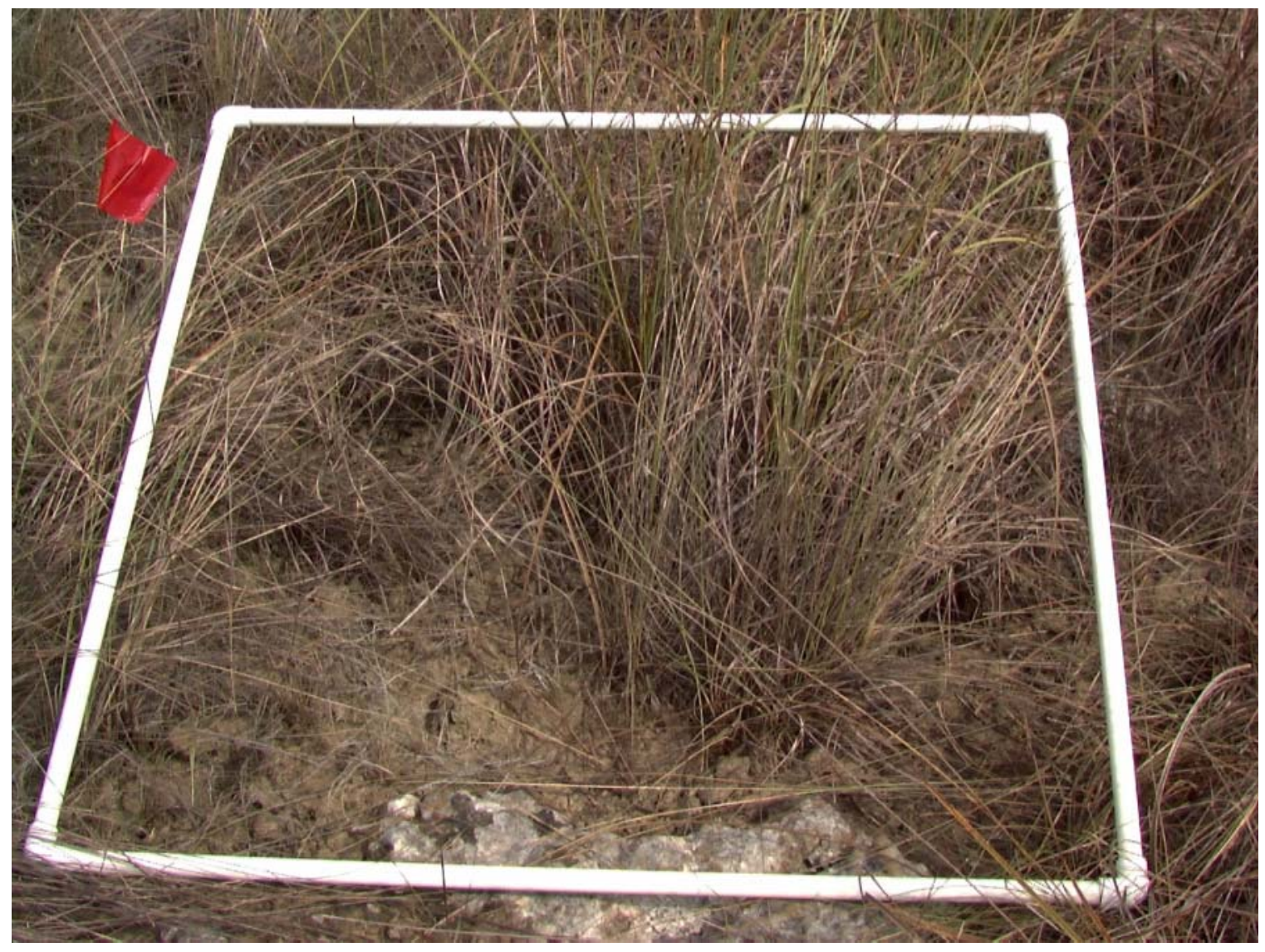

Figure 18. Emergent macrophytic cover in reference standard Rocky Flats Everglades wetland showing 20 to 45 percent cover

Percent cover of periphyton is used to quantify this variable. Measure it using the following procedure:

(1) Visually estimate the percentage of the ground surface that is covered by emergent periphyton in each of three $1-\mathrm{m}^{2}\left(3.3-\mathrm{ft}^{2}\right)$ subplots.

(2) Average the percent cover from all of the subplots.

(3) Report periphyton cover as a percent between 0 and 100.

(4) Using Figure 19 for Rocky Flats or Figure 20 for Marl Flats Everglades wetlands, determine the subindex score for the percent cover of periphyton. 


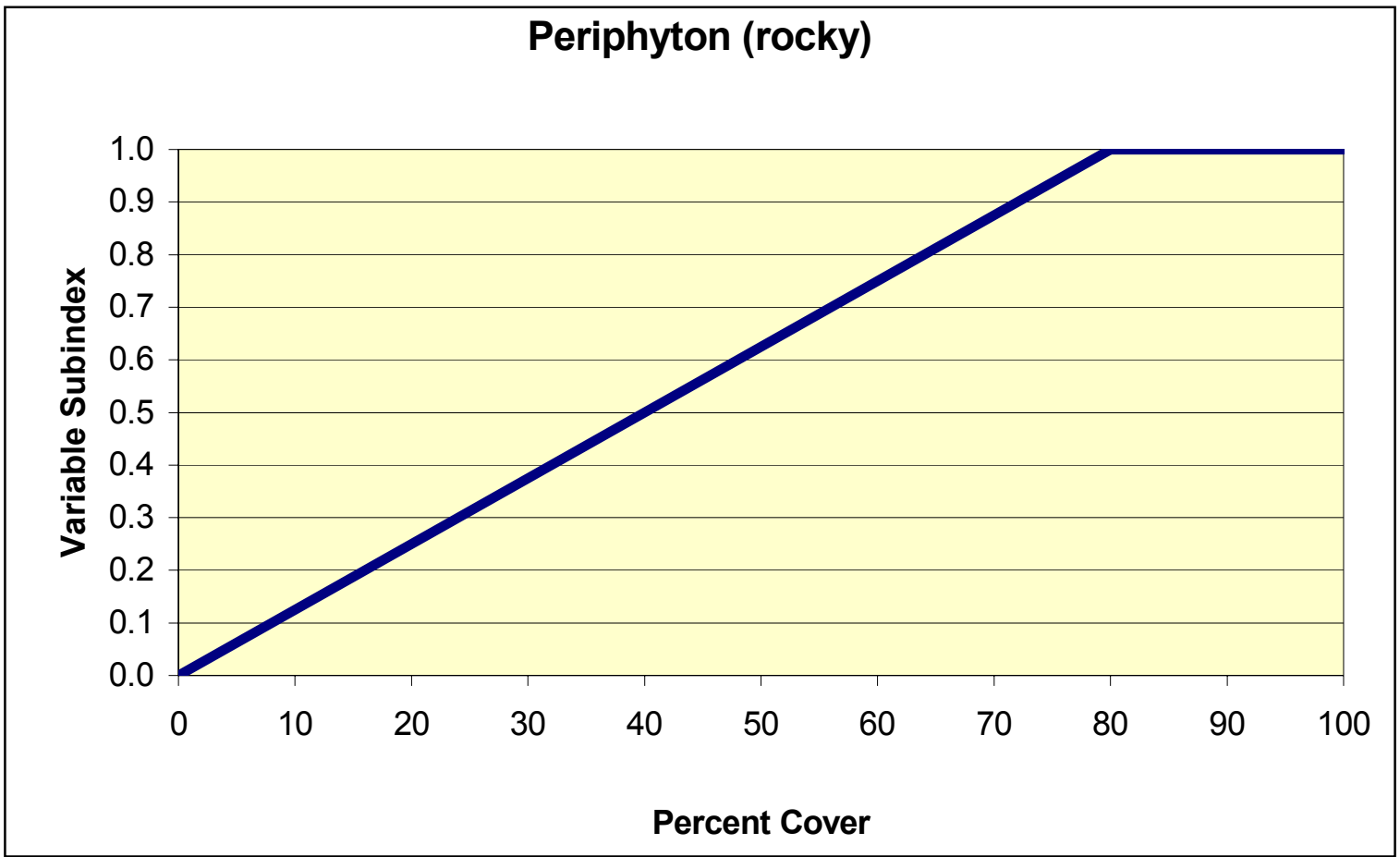

Figure 19. Relationship between periphyton and functional capacity for Rocky Flats Everglades wetlands

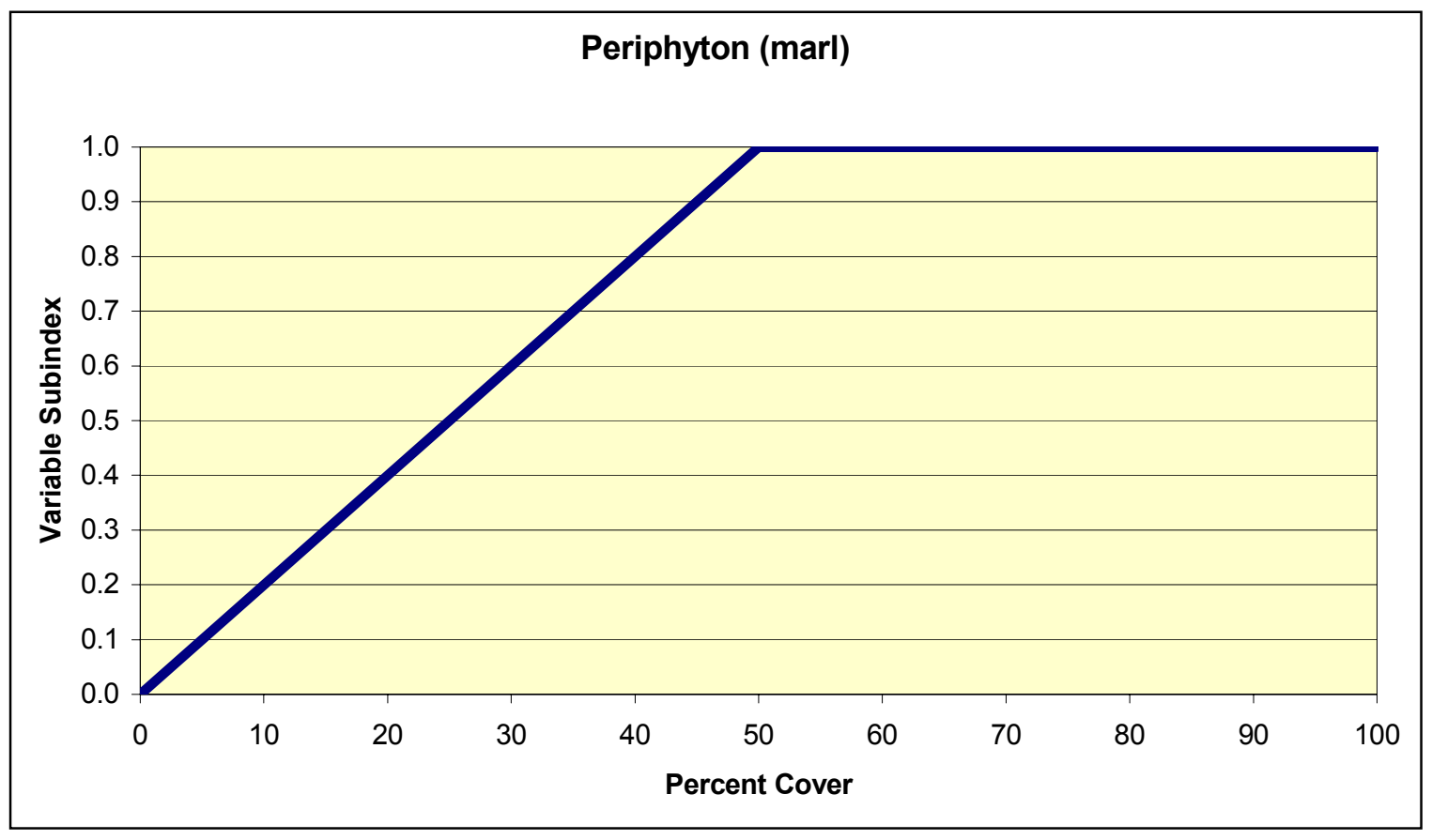

Figure 20. Relationship between periphyton and functional capacity for Marl Flats Everglades wetlands 
In the Everglades this variable is applicable only to the Rocky and Marl Flats subclasses. In the Everglades reference wetlands, periphyton cover ranged from 0 to 96 percent for both Rocky and Marl Flats wetlands. Based on data from reference standard wetlands, a variable subindex of 1.0 is assigned to sites with periphyton cover between 80 and 100 percent for Rocky Flats wetlands and between 50 and 100 percent for Marl Flats wetlands (Figure 21). Zero percent cover of periphyton indicates severely altered conditions. As percent cover of periphyton decreases below 80 percent for Rocky Flats sites and 50 percent for Marl Flats sites, a linearly decreasing subindex score down to zero is assigned for Rocky and Marl Flats sites at zero percent cover of periphyton. This is based on the assumption that the decrease in periphyton cover indicates altered hydrology and/or disturbance such as plowing. The rate at which the subindex decreases and the selection of zero as variable subindex end point at zero percent cover are based on the assumption that the relationship between percent cover of periphyton and altered hydrology is linear. These assumptions could be validated using the independent, quantitative measures of function defined in the previous paragraph.

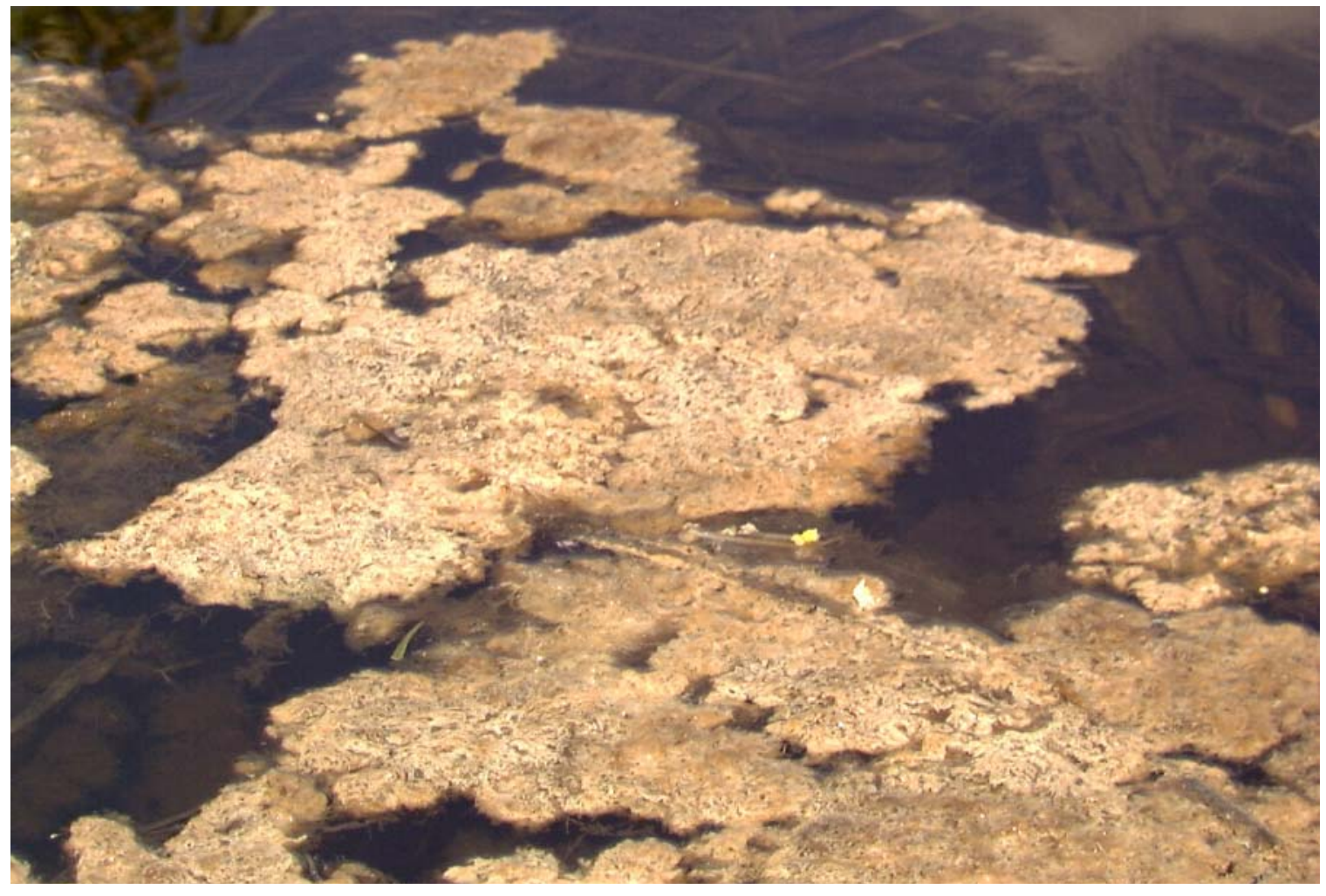

Figure 21. Floating mat of periphyton showing 50 to 100 percent cover

Plant Species Composition $\left(V_{\text {СомP }}\right)$. Plant species composition represents the dominance of certain native wetland plants relative to sites with the least disturbance in the Everglades. Ideally, plant species composition would be determined with intensive sampling of herbaceous species. Unfortunately, the time and taxonomic expertise required to accomplish this are not available in the 
context of rapid assessment. Thus, the focus here is on the dominant species in the herbaceous strata. This variable is only used for Marl and Organic Flats Everglades wetlands subclasses.

Percent concurrence with the dominant species in the herbaceous stratum is used to quantify this variable. Measure it with the following procedure:

(1) Identify the dominant species in the canopy, understory vegetation, and ground vegetation strata using the 50/20 rule. ${ }^{1}$ To apply the 50/20 rule, rank species from the herbaceous stratum in descending order of abundance. Identify dominants by summing the relative abundances beginning with the most abundant species in descending order until 50 percent is exceeded. Additional species with $\geq 20$ percent relative abundance should also be considered as dominants. If no species is equal to or greater than 20 percent, then identify the species with the greatest percent cover. Accurate species identification is critical for determining the dominant species in each plot. Sampling during the dormant season or after a fire may require a high degree of proficiency. Users who do not feel confident in identifying herbaceous plant species should get help with plant identification.

(2) Calculate percent concurrence by comparing the list of dominant plant species to the list of dominant species in reference standard wetlands (Table 13 or Table 14). For example, if all the dominants from the area being assessed occur on the list of dominants from reference standard wetlands, then there is 100 percent concurrence. If three of the five dominant species from the area being assessed occur on the list, then there is a 60 percent concurrence.

(3) Report concurrence of species dominants as a percent between 0 and 100.

In the Everglades reference wetlands, percent concurrence with dominant species ranged from 0 to 100 percent (Appendix D). Based on the data from reference standard sites, a variable subindex of 1.0 is assigned when concurrence with dominant species is 100 percent for a wetland subclass (Figure 22). As percent concurrence decreases, a linearly decreasing subindex down to zero is assigned based on the assumption that the relationship between plant species composition and the capacity of Everglades wetlands to maintain a characteristic plant community is linear (Figure 23).

Number of Native Wetland Species $\left(V_{\text {NATIVE }}\right)$. This variable represents the number of native wetland species that occur on a site in the Rocky Flats Everglades ecosystem. In general, Rocky Flats Everglades wetlands support over 100 native wetland species (Lodge 1994). Disturbed sites usually have fewer native wetland species than undisturbed sites; disturbed sites can become

\footnotetext{
${ }^{1}$ Memorandum, 6 March 1992, Office, Chief of Engineers, Clarification of Use of the 1987 Delineation Manual.
} 


\begin{tabular}{|c|c|}
\hline \multicolumn{2}{|c|}{$\begin{array}{l}\text { Table } 13 \\
\text { Dominant Plant Species, Marl Flats }\end{array}$} \\
\hline Scientific Name & Common Name \\
\hline Andropogon glomeratus & Bushy bluestem \\
\hline Bacopa caroliniana & Blue waterhyssop \\
\hline Cladium jamaicense & Saw grass \\
\hline Crinum americanun & Seven sisters \\
\hline Eragrostis refracta & Coastal lovegrass \\
\hline Hyptis alata & Clustered bushmint \\
\hline Mikania scandens & Climbing hempweed \\
\hline Muhlenbergia capillaris & Muhly grass \\
\hline Panicum tenerum & Bluejoint panic grass \\
\hline Paspalum monastachyum & Gulfdune paspalum \\
\hline Pluchea rosea & Rosy camphorweed \\
\hline Proserpinaca palustris & Marsh mermaid weed \\
\hline Rhynchospora divergens & Spreading beaksedge \\
\hline Rhynchospora microcarpa & Southern beaksedge \\
\hline Rhynchospora tracyi & Tracy's beaksedge \\
\hline Schizachyrium rhizomatum & Florida little bluestem \\
\hline Spartina alterniflora & Smooth cordgrass \\
\hline Utricularia purpurea & Eastern purple bladderwort \\
\hline
\end{tabular}

\section{Table 14}

\section{Dominant Plant Species, Organic Flats}

\begin{tabular}{||l|l|}
\hline \hline Scientific Name & Common Name \\
\hline \hline Bacopa caroliniana & Blue waterhyssop \\
\hline Cladium jamaicense & Saw grass \\
\hline Eleocharis cellulosa & Coastal spikerush \\
\hline Eleocharis elongata & Slim spikerush \\
\hline Panicum hemitomon & Maiden cane \\
\hline Peltandra virginica & Green arrow arum \\
\hline Polygonum hydropiperoides & Swamp smartweed \\
\hline Pontederia cordata & Pickerelweed \\
\hline Sagittaria lanceolata & Bulltongue arrowhead \\
\hline Utricularia foliosa & Leafy bladderwort \\
\hline Utricularia purpurea & Eastern purple bladderwort \\
\hline
\end{tabular}

dominated by only one or two species. Ideally, number of native wetland species would be determined with intensive sampling over the entire site. Unfortunately, the time required is not practical for a rapid assessment. This variable is determined using the following procedure.

(1) During field reconnaissance and plot and subplot sampling, count each native vegetative species that has a Wetland Indicator Status of Facultative (FAC), Facultative Wetland (FACW), or Obligate Wetland (OBG) in each strata (Appendix C, U.S. Fish and Wildlife Service 1988). Add the number of native wetland species from each vegetative strata and report the total number of native wetland species. Users do not need to determine the taxonomic classification of each species, but must be able to recognize those species who are not native to Florida and are not typically found in wetlands. Users that do not feel confident in making these identifications should get help with plant identification.

(2) Using Table 15, assign a variable subindex score. 


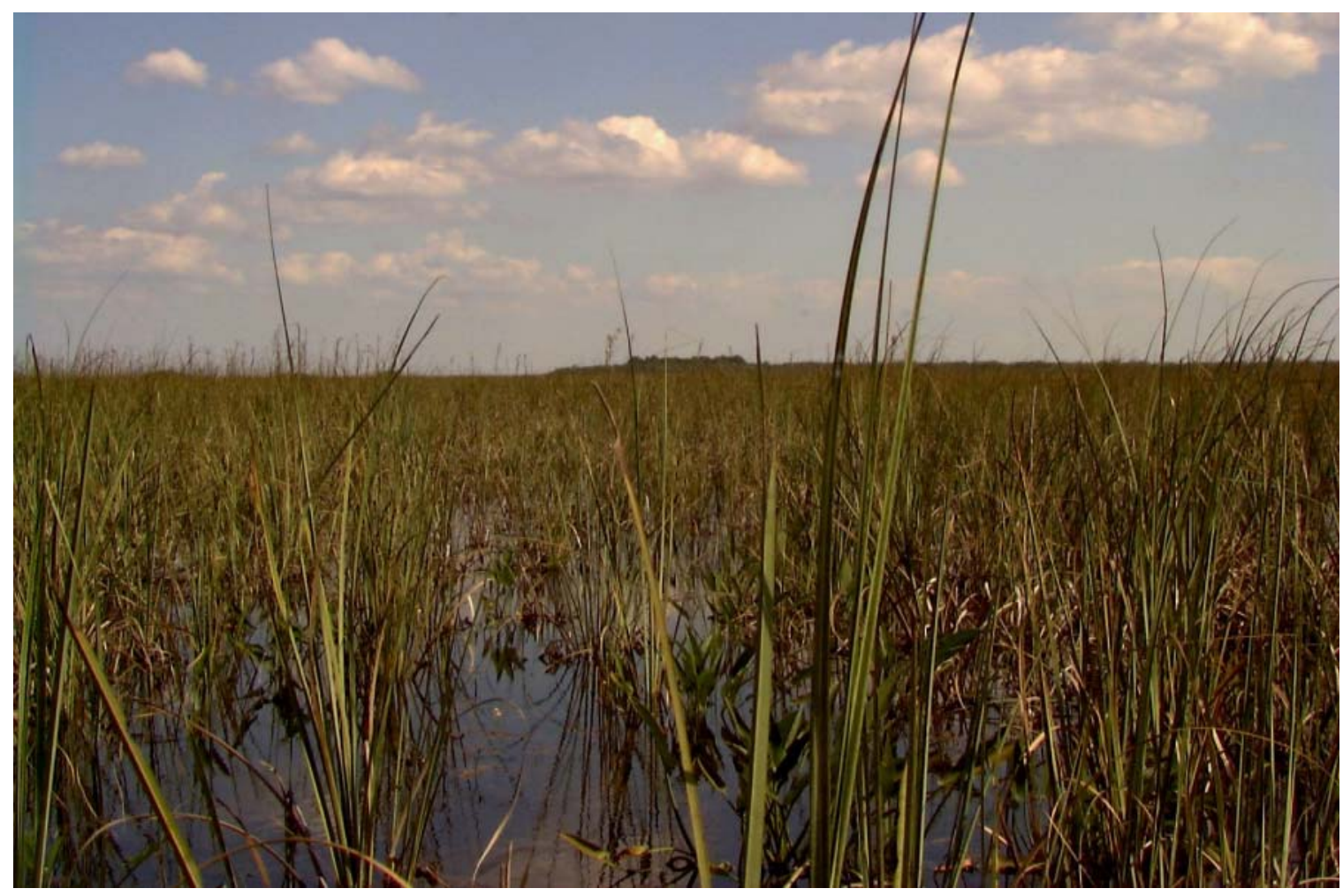

Figure 22. Reference standard Organic Flats Everglades dominated by Cladium jamaicense (saw grass)

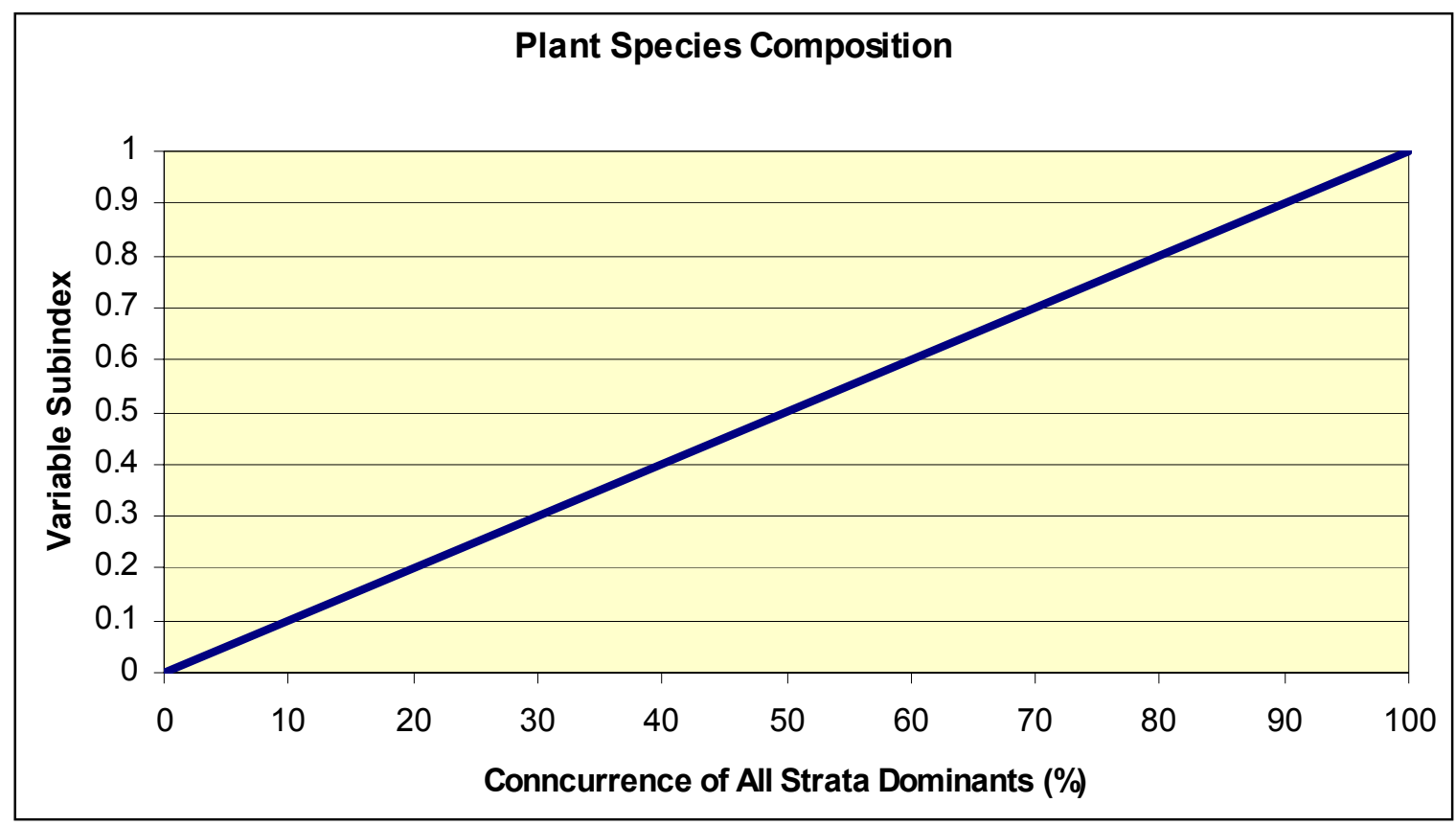

Figure 23. Relationship between percent concurrence of strata dominants and functional capacity 


\begin{tabular}{|c|c|}
\hline \multicolumn{2}{|c|}{$\begin{array}{l}\text { Table } 15 \\
\text { Number of Native Wetland Species in Rocky Flats Everglades } \\
\text { Wetlands }\end{array}$} \\
\hline Number of Species & Subindex Score \\
\hline$>20$ & 1.0 \\
\hline 19 & 0.95 \\
\hline 18 & 0.9 \\
\hline 17 & 0.85 \\
\hline 16 & 0.8 \\
\hline 15 & 0.75 \\
\hline 14 & 0.7 \\
\hline 13 & 0.65 \\
\hline 12 & 0.6 \\
\hline 11 & 0.55 \\
\hline 10 & 0.5 \\
\hline 9 & 0.45 \\
\hline 8 & 0.4 \\
\hline 7 & 0.35 \\
\hline 6 & 0.3 \\
\hline 5 & 0.25 \\
\hline 4 & 0.20 \\
\hline 3 & 0.1 .5 \\
\hline 2 & 0.1 \\
\hline 1 & 0.05 \\
\hline 0 & 0 \\
\hline
\end{tabular}

In the Rocky Flats Everglades reference wetlands the number of native wetland species ranged from 3 to 39 (Appendix D). Based on the data from reference standard sites, a variable subindex score of 1.0 would be assigned when the number of native wetland species is 20 or greater. As the number of species decreases, a linearly decreasing subindex down to zero is assigned based on the assumption that the relationship between the number of native wetland species and the capacity of Rocky Flats Everglades wetlands to maintain a diverse native wetland plant community is linear.

\section{Functional Capacity Index}

The assessment models for calculating the FCI are as follows:

a. For Rocky Flats Everglades wetlands

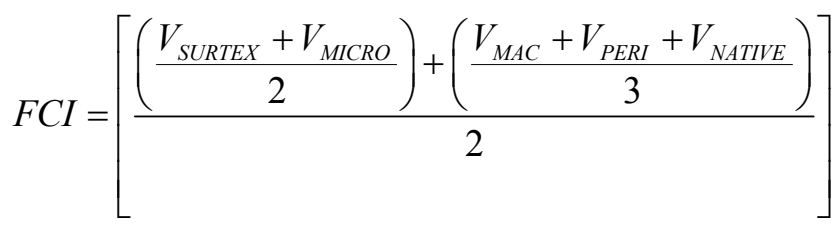

b. For Marl Flats Everglades wetlands 


$$
F C I=\left[\frac{\left(\frac{V_{\text {SURTEX }}+V_{\text {MICRO }}}{2}\right)+\left(\frac{V_{\text {MAC }}+V_{\text {PERI }}+V_{\text {COMP }}}{3}\right)}{2}\right]
$$

c. For Organic Flats Everglades wetlands

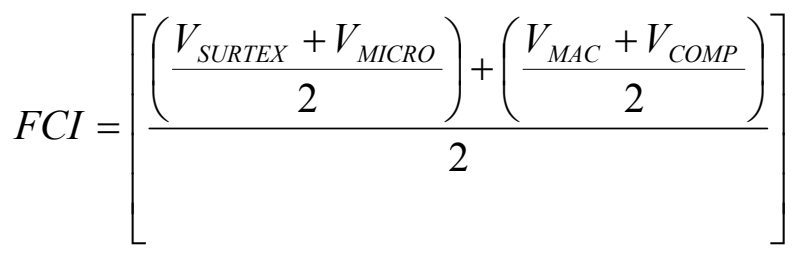

In these models, the nutrient cycling capacity of the Everglades wetland depends on soils and vegetation. The assumption is that if natural soils, microtopography, and vegetation are in place, then nutrient cycling is occurring at an appropriate rate. If soil texture $\left(V_{\text {SURTEX }}\right)$ has been scraped and removed or altered by rock plowing or the addition of contrasting fill material, then the capacity of the wetland to cycle nutrients has been reduced. The alteration of the microtopography by rock plowing, land leveling, or bedding relates to soils and vegetation as well as the ability to restore nutrient cycling.

Rocky Flats Everglades wetland vegetation is represented by percent cover of macrophytic vegetation $\left(V_{M A C}\right)$, periphyton $\left(V_{P E R I}\right)$, and number of native wetland species $\left(V_{\text {NATIVE }}\right)$. These three partially compensatory variables are combined using an arithmetic mean. This is based on an assumption of equal importance of the right amount of vegetative cover and the right kinds of plants being present.

Marl Flats Everglades wetland vegetation is represented by percent cover of macrophytic vegetation $\left(V_{M A C}\right)$, periphyton $\left(V_{P E R I}\right)$, and plant species composition $\left(V_{\text {СОMP }}\right)$. These three partially compensatory variables are combined using an arithmetic mean. This is based on an assumption of equal importance of the right amount of vegetative cover and the right kinds of plants being present.

Organic Flats Everglades wetland vegetation is represented by percent cover of macrophytic vegetation $\left(V_{M A C}\right)$ and plant species composition $\left(V_{\text {СOMP }}\right)$. These two partially compensatory variables are combined using an arithmetic mean. This is based on an assumption of equal importance of the right amount of vegetative cover and the right kinds of plants being present.

Both parts of the model are combined using an arithmetic mean. The implications are that all variables would have to equal zero for the function to receive an $\mathrm{FCI}$ of zero. 


\section{Function 3: Characteristic Plant Community}

\section{Definition}

Maintain Characteristic Plant Community is defined as the capacity of an Everglades wetland to provide the environment necessary for a characteristic plant community to develop and be maintained. In assessing this function, one must consider both the extant plant community as an indication of current conditions and the physical factors that determine whether or not a characteristic plant community is likely to be maintained in the future. Potential independent, quantitative measures of this function, based on vegetation composition and abundance, include similarity indices (Ludwig and Reynolds 1988) or ordination axis scores from detrended correspondence analysis or other multivariate technique (Kent and Coker 1995). An alternative, independent, quantitative measure of this function, based on vegetation composition and abundance as well as environmental factors, is ordination axis scores from canonical correlation analysis (ter Braak 1994).

\section{Rationale for selecting the function}

The ability to maintain a characteristic plant community is important because of the intrinsic value of the plant community and the many attributes and processes of Everglades wetlands that are influenced by the plant community. For example, primary productivity, nutrient cycling, and the ability to provide a variety of habitats necessary to maintain local and regional diversity of animals (Harris and Gosselink 1990) are directly influenced by the plant community.

\section{Characteristics and processes that influence the function}

A variety of physical and biological factors determine the ability of an Everglades wetland to maintain a characteristic plant community. One could simply measure the extant plant community and assume that the wetland was performing the function at a characteristic level if the composition and structure were similar to reference standard wetlands. However, there are potential problems with this approach because of the dynamic nature of plant communities. For instance, microtopographic changes and soil perturbations change the habitat characteristics for characteristic plant communities. The presence of exotic species also indicates habitat disturbances and long-term changes to the system.

\section{Description of model variables}

Emergent Macrophytic Vegetation Cover $\left(\boldsymbol{V}_{\boldsymbol{M A C}}\right)$. This variable represents the total cover of macrophytic vegetation in the wetland and is defined as the average percent cover of emergent macrophytic vegetation $<1 \mathrm{~m}(3.3 \mathrm{ft})$ in height within multiple plots, exclusive of submerged aquatic vegetation and periphyton. 
Percent cover of emergent macrophytic vegetation is used to quantify this variable. Measure it using the following procedure:

(1) Visually estimate the percentage of the ground surface that is covered by emergent macrophytic vegetation by mentally projecting the leaves and stems to the ground surface in each of three $1-\mathrm{m}^{2}\left(3.3-\mathrm{ft}^{2}\right)$ subplots.

(2) Average the percent cover from all of the subplots.

(3) Report emergent macrophytic vegetation cover as a percent between 0 and 100 .

(4) Using Figure 24 for Rocky Flats, Figure 25 for Marl Flats, or Figure 26 for Organic Flats Everglades wetlands, determine the subindex score for percent cover of macrophytic vegetation.

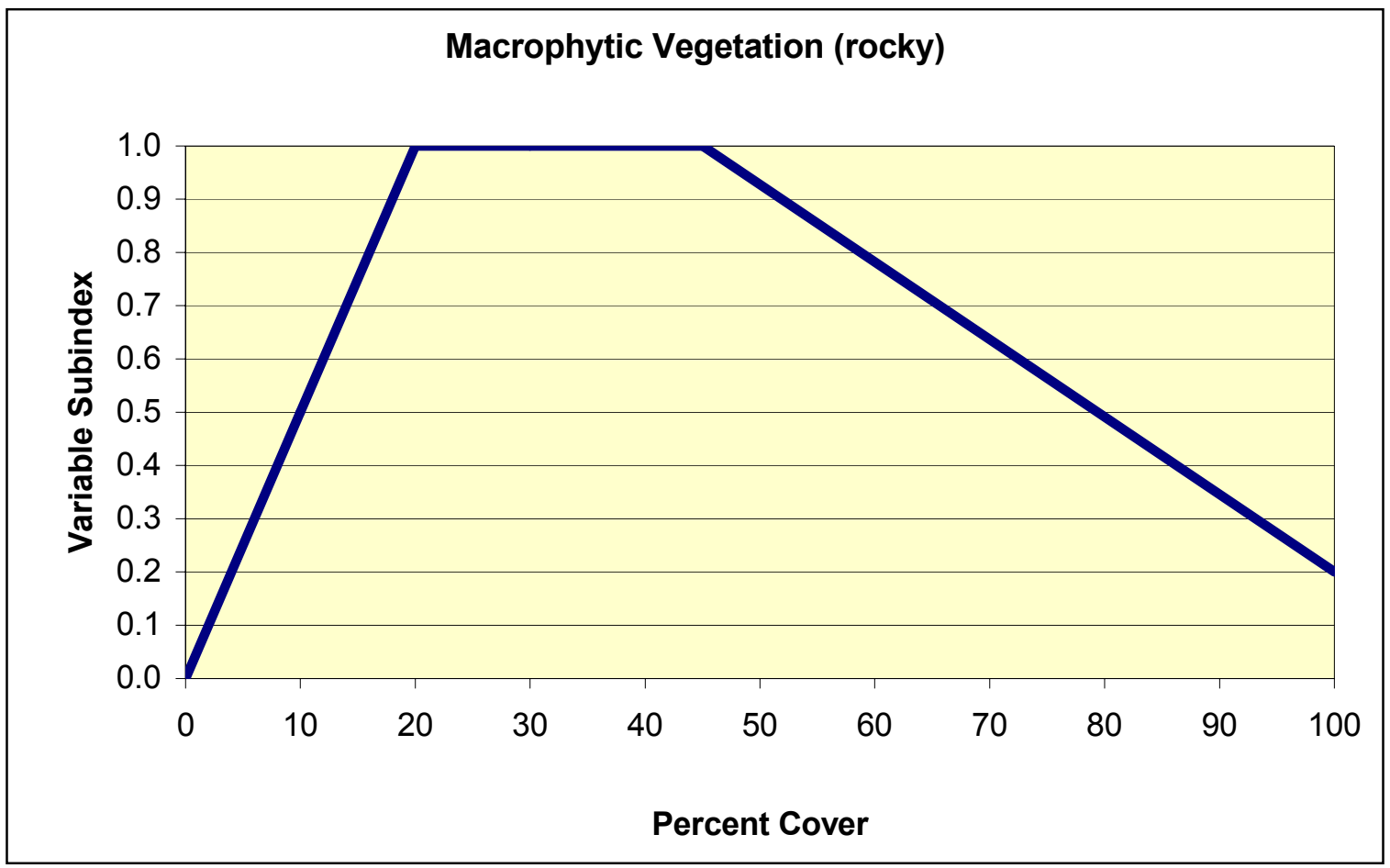

Figure 24. Relationship between macrophytic vegetation and functional capacity for Rocky Flats Everglades wetlands

In the Everglades reference wetlands, emergent macrophytic vegetation cover ranged from 2 to 90 percent for Rocky Flats wetlands, 12 to 98 percent for Marl Flats wetlands, and 3 to 98 percent for Organic Flats wetlands. Based on data from reference standard wetlands sites, a variable subindex of 1.0 is assigned to sites with emergent macrophytic vegetative cover between 20 and 45 percent for Rocky Flats wetlands (Figure 27), between 40 and 65 percent 


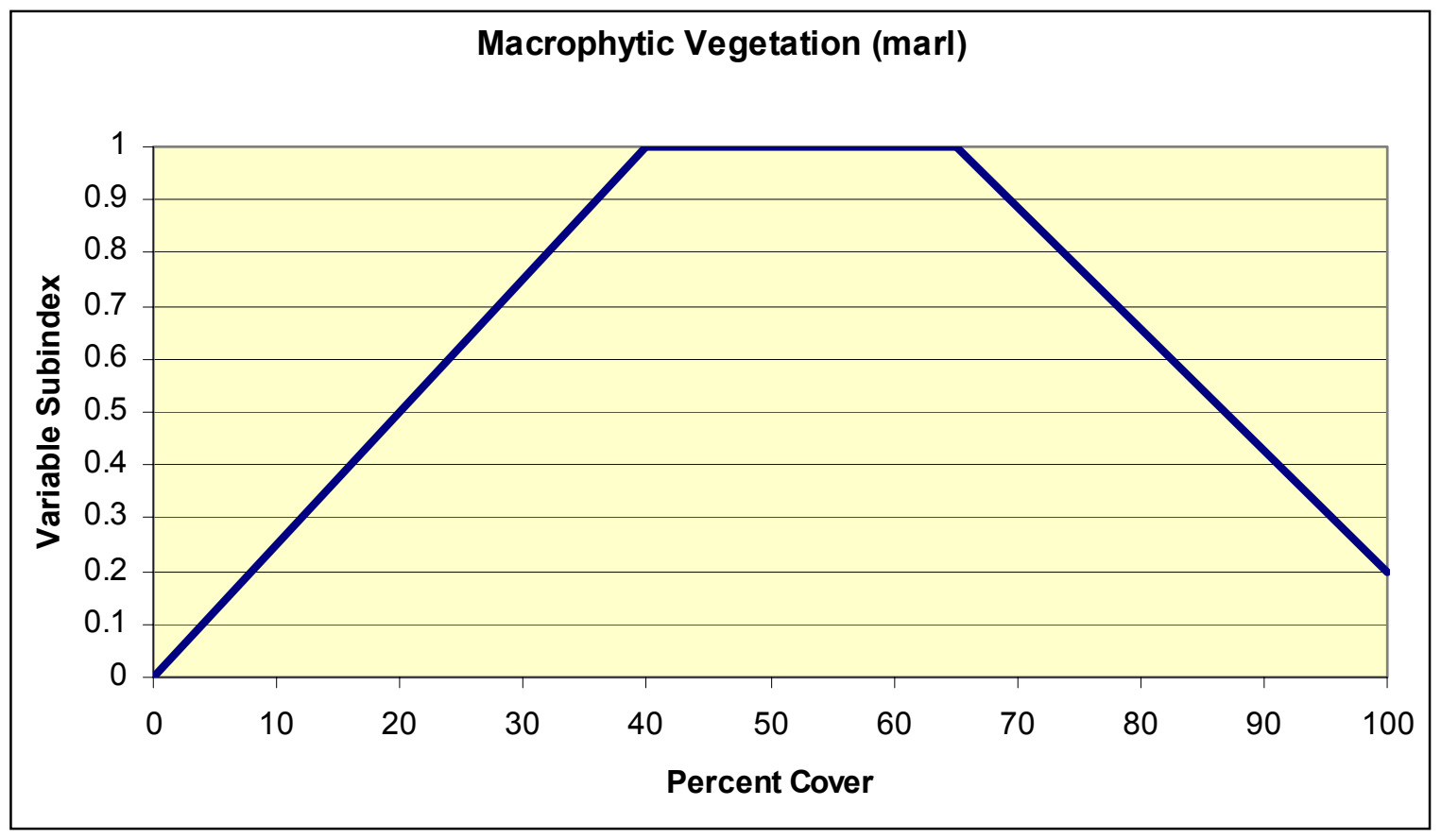

Figure 25. Relationship between macrophytic vegetation and functional capacity for Marl Flats Everglades wetlands

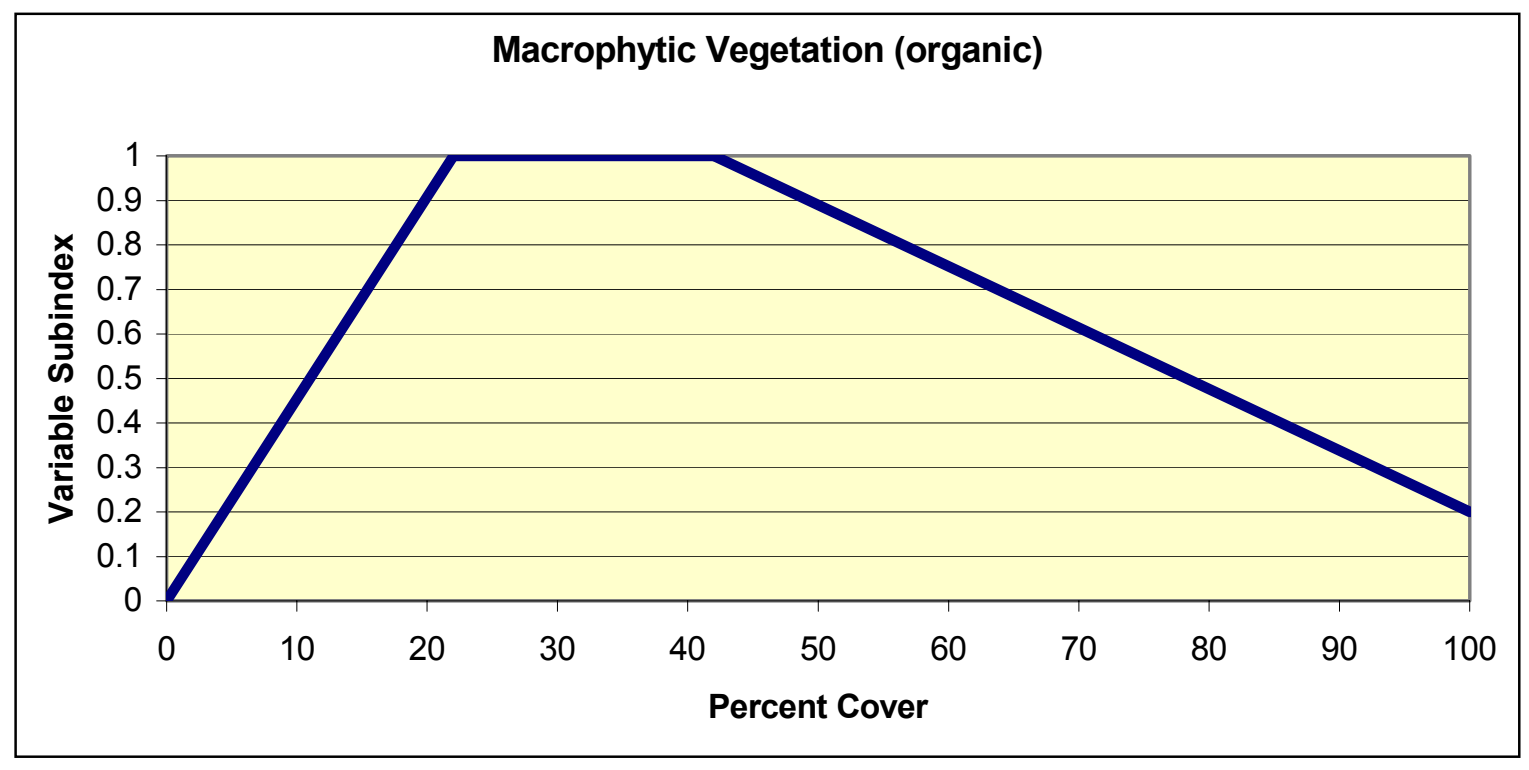

Figure 26. Relationship between macrophytic vegetation and functional capacity for Organic Flats Everglades wetlands 
for Marl Flats wetlands, and between 22 and 42 percent for Organic Flats wetlands. Zero percent cover of macrophytic vegetation, while not measured, would indicate severely altered conditions. As percent cover of emergent macrophytic vegetation increases above 45 percent for Rocky Flats sites, 65 percent for Marl Flats sites, and 42 percent for Organic Flats sites, a linearly decreasing subindex score down to 0.2 is assigned for Rocky Flats, Marl Flats, and Organic Flats sites at 100 percent cover of emergent macrophytic vegetation. This is based on the assumption that the increase in emergent macrophytic vegetation cover indicates unnatural levels of productivity such as following fertilization. The rate at which the subindex decreases and the selection of 0.2 as the variable subindex end point at 100 percent cover are based on the assumption that the relationship between percent cover of emergent macrophytic vegetation and maintaining a characteristic plant community is linear and some community characteristics are present even when percent cover is higher than reference standard. These assumptions could be validated using the independent, quantitative measures of function defined in the previous paragraph.

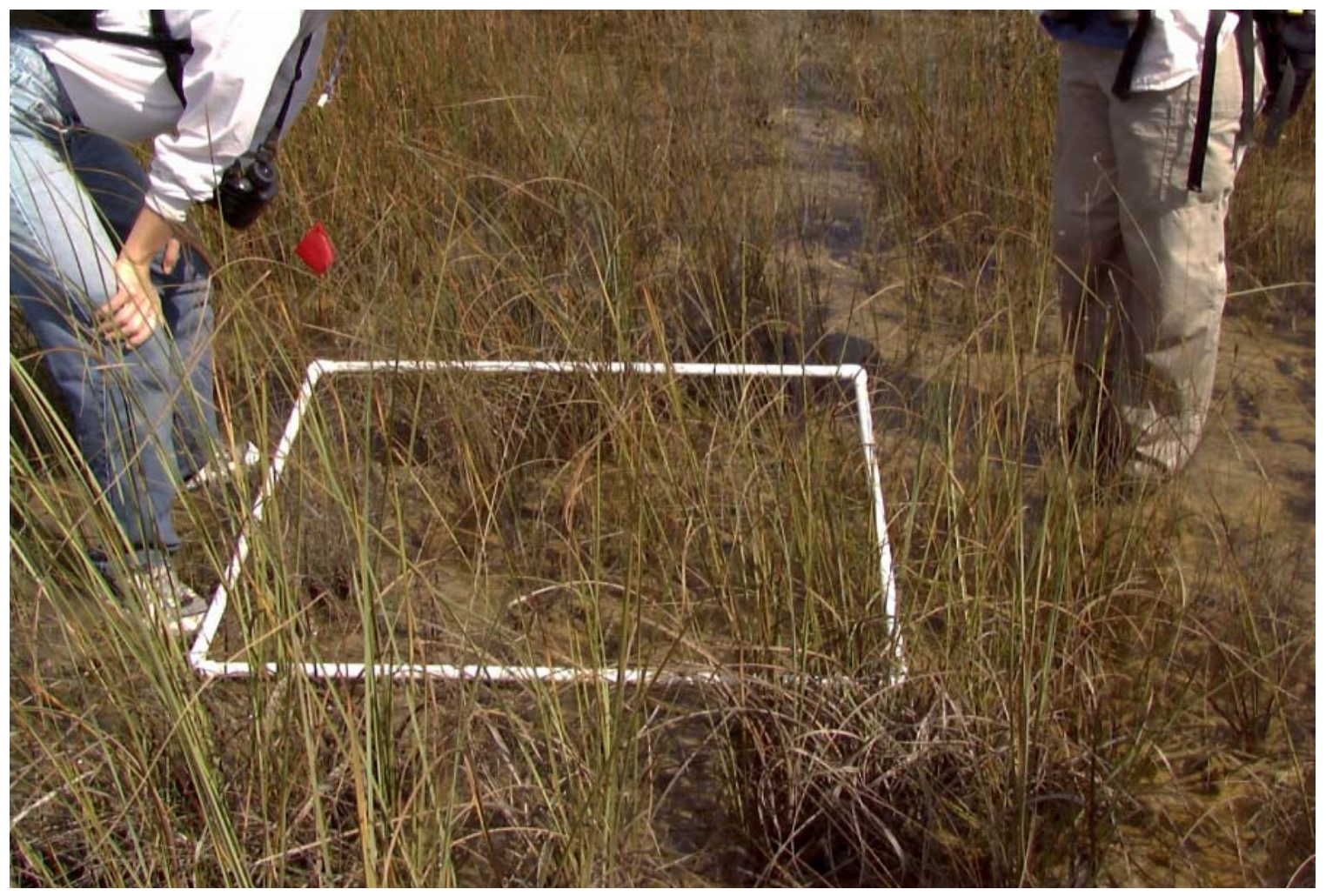

Figure 27. Percent cover of emergent macrophytic vegetation in a reference standard Rocky Flats Everglades wetland showing 20 to 45 percent cover

Periphyton Cover $\left(\boldsymbol{V}_{\text {PERI }}\right)$. This variable represents the total cover of periphyton in the wetland and is defined as the average percent cover of periphyton within multiple plots. 
Percent cover of periphyton is used to quantify this variable. Measure it using the following procedure:

(1) Visually estimate the percentage of the ground surface covered by emergent periphyton in each of three $1-\mathrm{m}^{2}\left(3.3-\mathrm{ft}^{2}\right)$ subplots.

(2) Average the percent cover from all of the subplots.

(3) Report periphyton cover as a percent between 0 and 100.

(4) Using Figure 28 for Rocky Flats or Figure 29 for Marl Flats Everglades wetlands, determine the subindex score for the percent cover of periphyton.

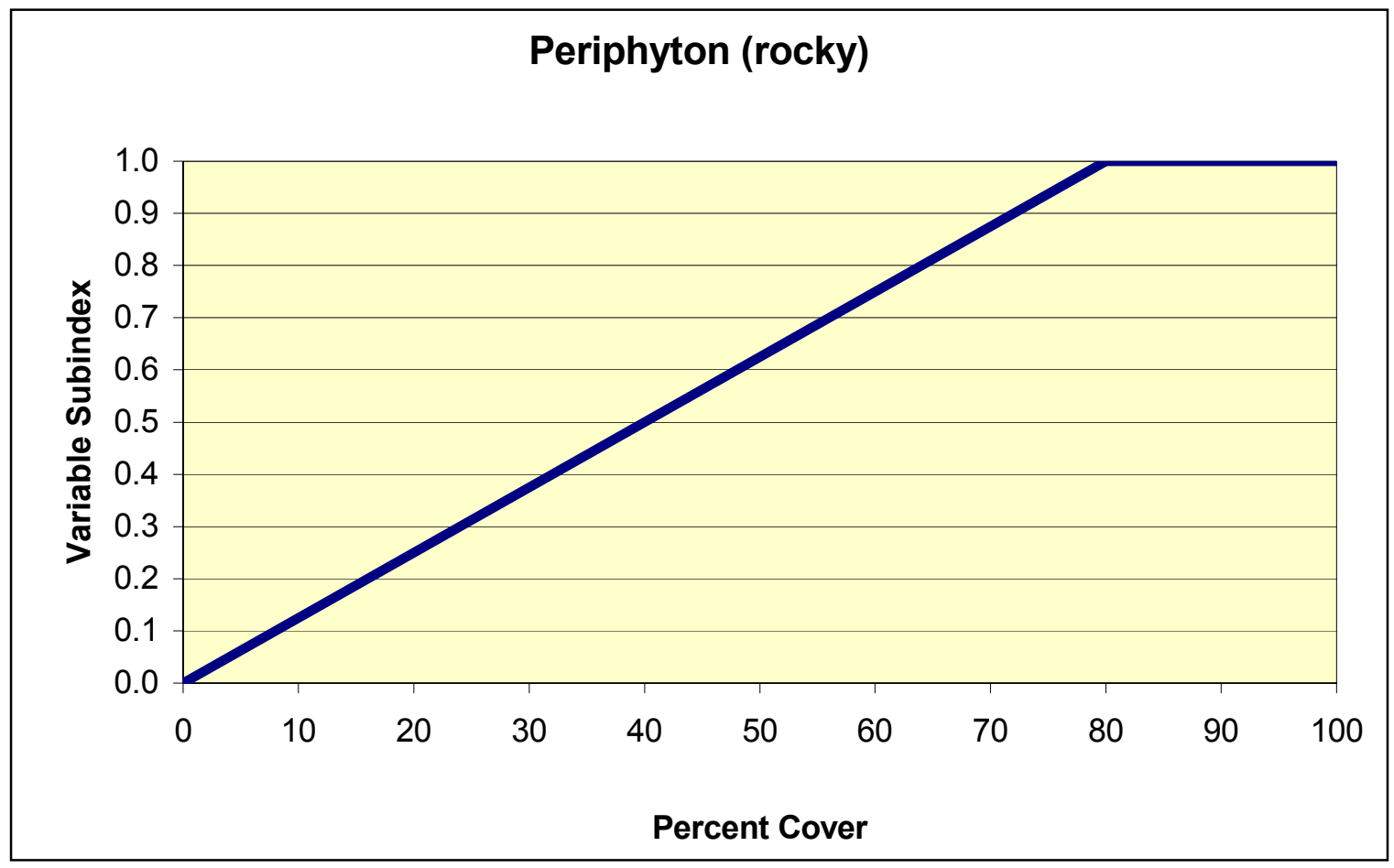

Figure 28. Relationship between periphyton and functional capacity for Rocky Flats Everglades wetlands

In the Everglades this variable is applicable only to the Rocky and Marl Flats subclasses. In the Everglades reference wetlands, periphyton cover (Figure 30) ranged from 0 to 96 percent for both Rocky and Marl Flats wetlands. Based on data from reference standard wetlands sites, a variable subindex of 1.0 is assigned to sites with periphyton cover between 80 and 100 percent for Rocky Flats wetlands and between 50 and 100 percent for Marl Flats wetlands. Zero percent cover of periphyton indicates severely altered conditions. As percent 


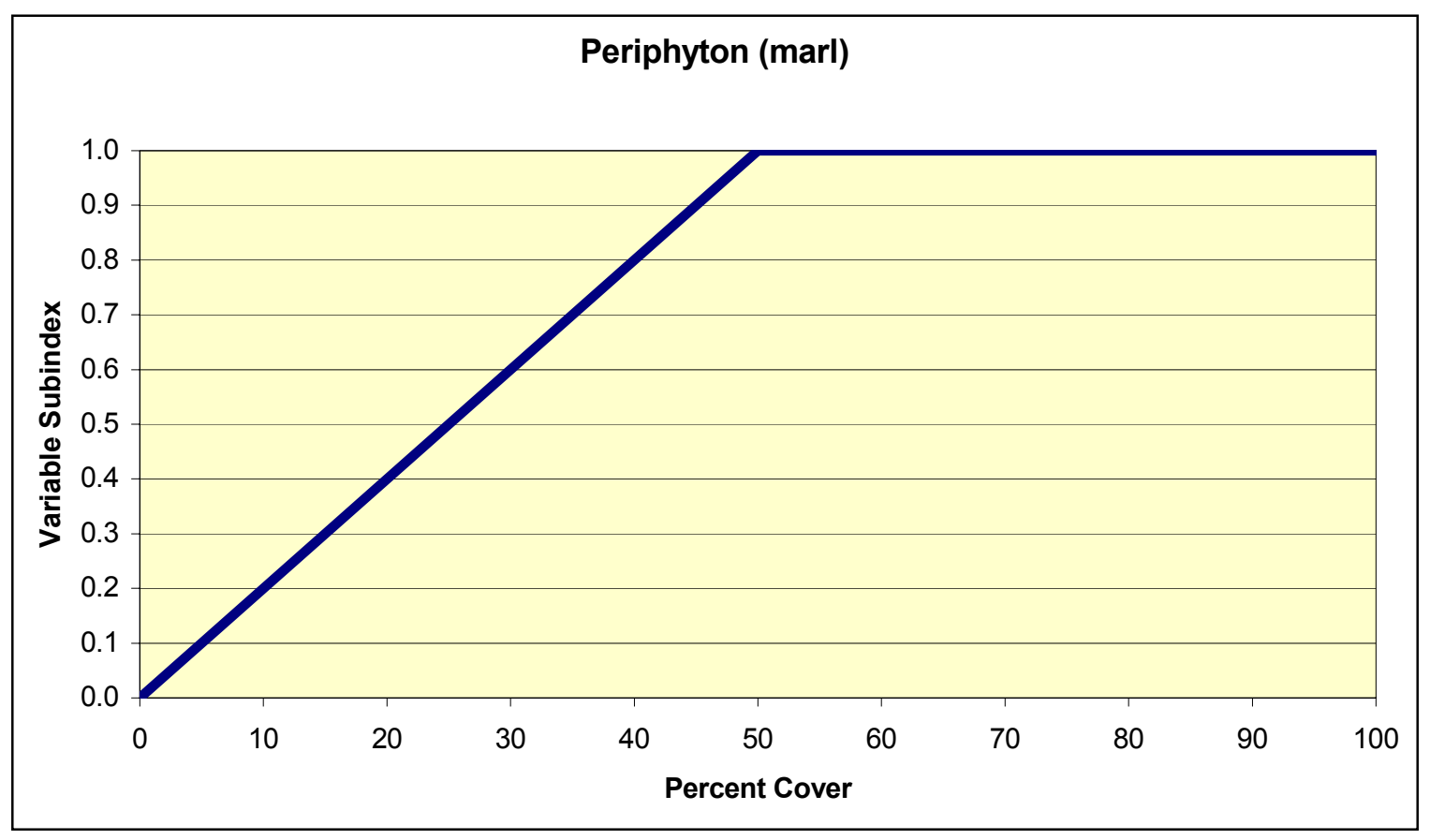

Figure 29. Relationship between periphyton and functional capacity for Marl Flats Everglades wetlands

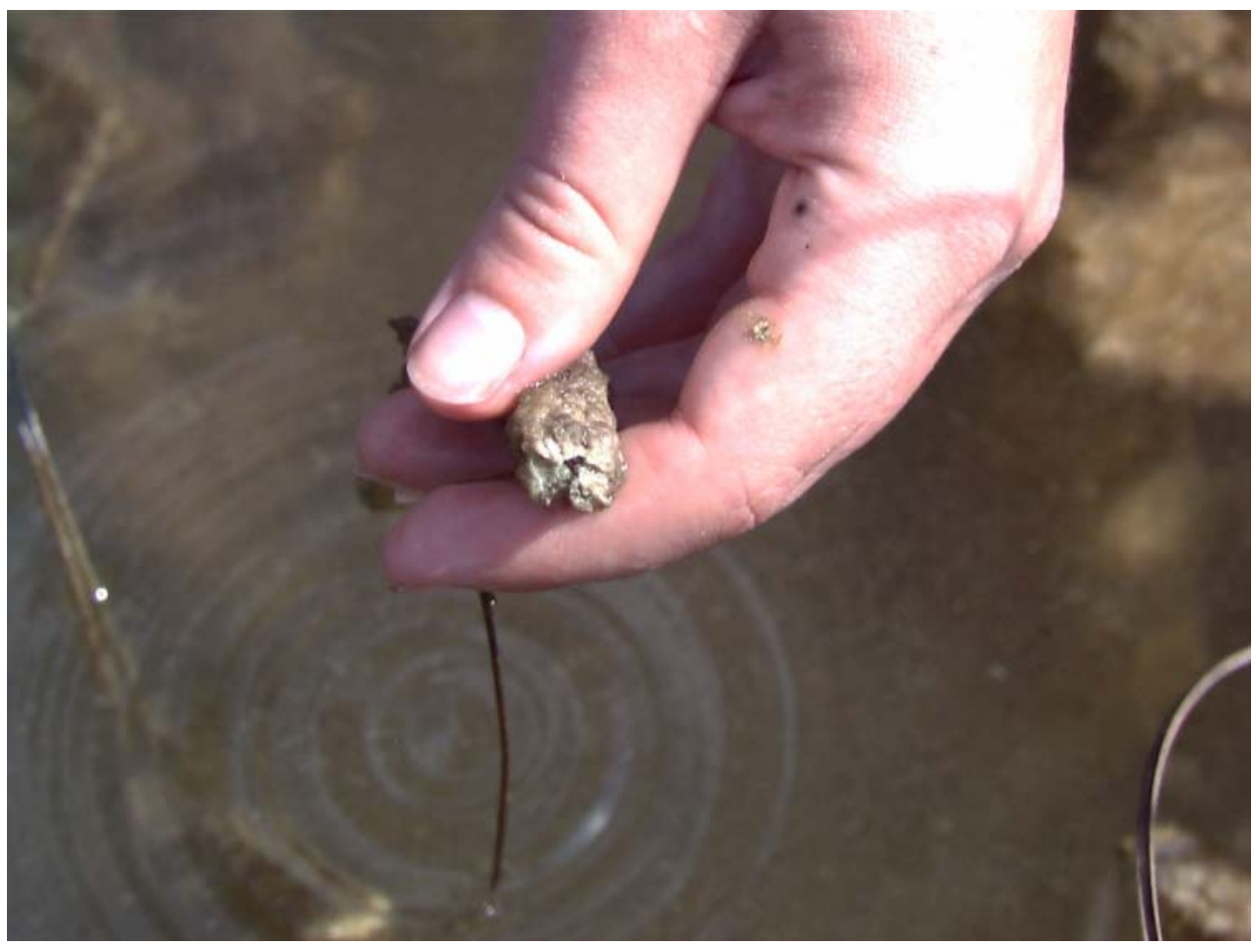

Figure 30. Periphyton formed around stem 
cover of periphyton decreases below 80 percent for Rocky Flats sites and 50 percent for Marl Flats sites, a linearly decreasing subindex score down to zero is assigned for Rocky Flats and Marl Flats sites at 0 percent cover of periphyton. This is based on the assumption that the decrease in periphyton cover indicates altered hydrology and/or disturbance such as plowing. The rate at which the subindex decreases and the selection of zero as variable subindex end point at zero percent cover are based on the assumption that the relationship between percent cover of periphyton and an altered plant community is linear. These assumptions could be validated using the independent, quantitative measures of function defined in the preceding paragraph.

Invasive Vegetation Cover $\left(V_{\text {INVASIVE }}\right)$. This variable, which represents the total cover of invasive vegetation in the wetland, is defined as the average percent cover of invasive vegetation in all strata within multiple plots. For this Guidebook, invasive species are those species identified by the Florida Exotic Pest Plants Council (2001) (Table 16).

Percent cover of invasive vegetation is used to quantify this variable. Measure it using the following procedure:

(1) Visually estimate the percentage of the ground surface that is covered by invasive vegetation by mentally projecting the leaves and stems to the ground surface in each 11.3-m (37.2-ft) radius plots, placed in representative portions of each WAA or PWAA. The number of plots required to adequately characterize an area will depend on the size and heterogeneity of the site. Chapter 5, "Assessment Protocol," provides guidance for determining the number and layout of sample points and sampling units.

(2) Average the percent cover from all of the plots.

(3) Report invasive vegetation cover as a percent between 0 and 100 .

(4) Using Figure 31, determine the subindex score for percent cover of invasive vegetation.

In the Everglades reference wetlands, invasive vegetation cover ranged from 0 to 72 percent for the three subclasses sampled (Figure 32). Based on data from reference standard wetlands, a variable subindex of 1.0 is assigned to sites with invasive vegetative cover between 0 and 3 percent for Rocky, Marl, and Organic Flats wetlands. As percent cover of invasive vegetation increases above 3 percent, a linearly decreasing subindex score down to zero is assigned for wetlands at 80 to 100 percent cover of invasive vegetation. This is based on the assumption that the increase in invasive vegetation cover indicates unnatural levels of productivity, changes in hydroperiod, and increased evapotranspiration. The rate at which the subindex decreases and the selection of zero as variable subindex end point at 100 percent cover are based on the assumption that the relationship between percent cover of invasive vegetation and impacts is linear. These assumptions could be validated using the independent, quantitative measures of function defined in the preceding paragraph. 


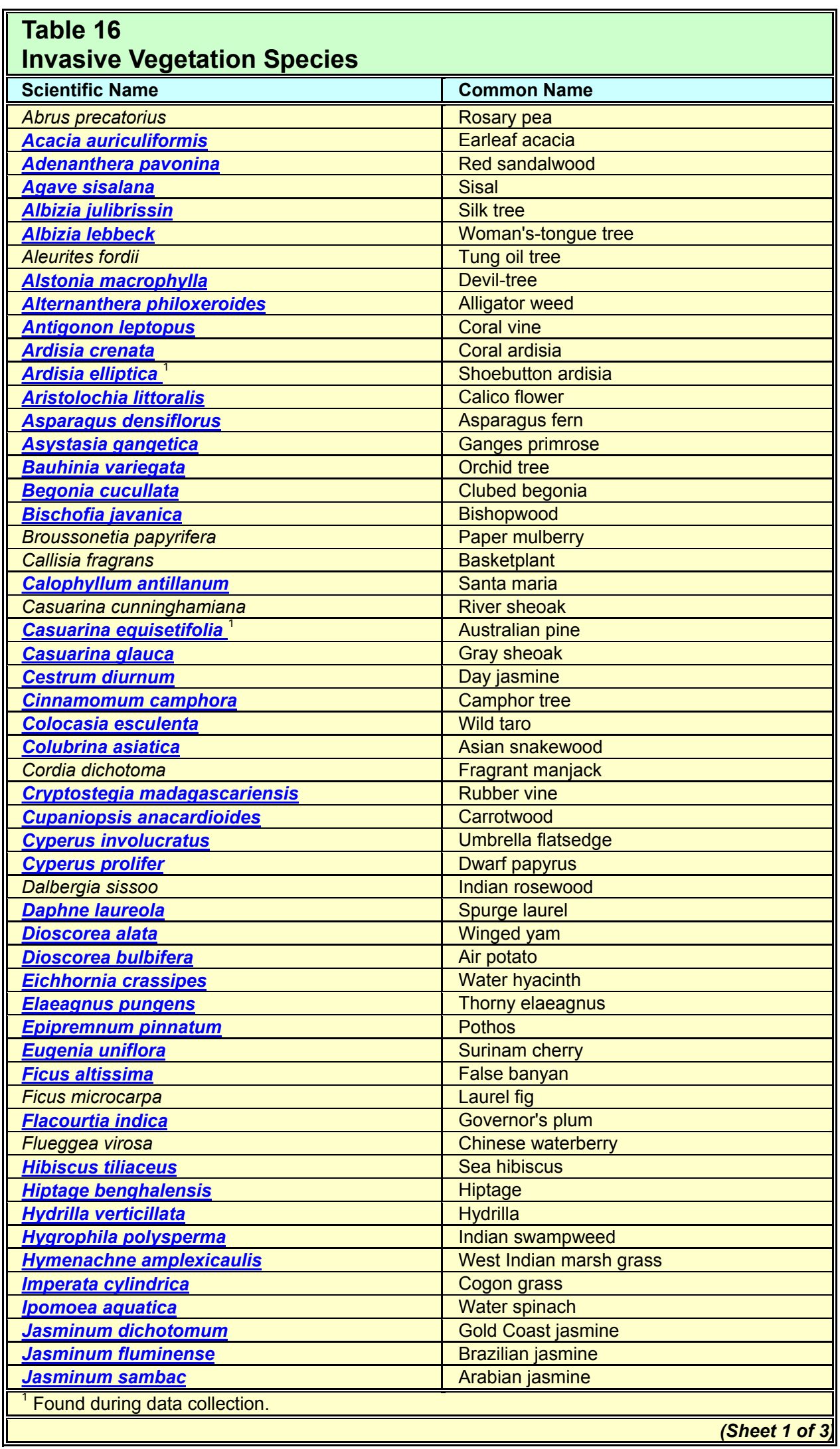




\begin{tabular}{|c|c|}
\hline \multicolumn{2}{|l|}{ Table 16 (Continued) } \\
\hline Scientific Name & Common Name \\
\hline Koelreuteria elegans & Golden rain tree \\
\hline Lantana camara & Lantana \\
\hline Leucaena leucocephala & Lead tree \\
\hline Ligustrum lucidum & Glossy privet \\
\hline Ligustrum sinense & Chinese privet \\
\hline Limnophila sessiliflora & Asian marshweed \\
\hline Lonicera japonica & Chinese honeysuckle \\
\hline Lygodium japonicum & Japanese climbing fern \\
\hline Lygodium microphyllum & Old world climbing fern \\
\hline Macfadyena unguis-cati & Claw vine \\
\hline Manilkara zapota & Sapodilla \\
\hline Melaleuca quinquenervia ${ }^{1}$ & Melaleuca \\
\hline Melia azedarach & Chinaberry tree \\
\hline Melinis minutiflora & Molasses grass \\
\hline Melinis repens & Natal grass \\
\hline Merremia tuberosa & Wood rose \\
\hline Mimosa pigra & Catclaw mimosa \\
\hline Murraya paniculata & Orange-jessamine \\
\hline Myriophyllum spicatum & Eurasian watermilfoil \\
\hline Nandina domestica & Heavenly bamboo \\
\hline Nephrolepis cordifolia & Boston fern \\
\hline Nephrolepis multiflora & Asian swordfern \\
\hline Neyraudia reynaudiana & Silk reed \\
\hline Ochrosia elliptica & Elliptic yellowwood \\
\hline Oeceoclades maculata & Ground orchid \\
\hline Paederia cruddasiana & Onion vine \\
\hline Paederia foetida & Skunk vine \\
\hline Panicum repens & Torpedo grass \\
\hline Passiflora biflora & Twin-flowered passionvine \\
\hline Passiflora foetida & Stinking passionflower \\
\hline Pennisetum purpureum $^{1}$ & Elephant grass \\
\hline Pennisetum setaceum & Crimson fountaingrass \\
\hline Phoenix reclinata & Reclining date palm \\
\hline Phyllostachys aurea & Golden bamboo \\
\hline Psidium cattleianum & Strawberry guava \\
\hline Psidium guajava $^{7}$ & Guava \\
\hline Pteris vittata & Ladder brake \\
\hline Ptychosperma elegans & Solitary palm \\
\hline Pueraria montana var. lobata & Kudzu \\
\hline Rhodomyrtus tomentosus & Rose myrtle \\
\hline Rhynchelytrum repens & Natal grass \\
\hline Ricinus communis & Castor bean \\
\hline Ruellia brittoniana & Mexican petunia \\
\hline Sansevieria hyacinthoides & Bowstring hemp \\
\hline Sapium sebiferum & Chinese tallow tree \\
\hline Scaevola sericea & Beach naupaka \\
\hline Schefflera actinophylla & Umbrella tree \\
\hline Schinus terebinthifolius $^{1}$ & Brazilian pepper-tree \\
\hline Senna pendula var. glabrata & Climbing cassia \\
\hline Sesbania punicea & Rattlebox \\
\hline Solanum diphyllum & Twinleaf nightshade \\
\hline Solanum jamaicense & Jamaica nightshade \\
\hline Solanum tampicense & Aquatic soda apple \\
\hline Solanum torvum & Turkeyberry \\
\hline Solanum viarum & Tropical soda apple \\
\hline Sphagneticola trilobata & Bay Biscayne creeping-oxeye \\
\hline Syngonium podophyllum & Arrowhead vine \\
\hline
\end{tabular}




\begin{tabular}{||l|l||}
\hline \hline Table 16 (Concluded) \\
\hline \hline Scientific Name & Common Name \\
\hline \hline Syzygium cumini & Java plum \\
\hline Syzygium jambos & Rose-apple \\
\hline Tectaria incisa & Incised halberd fern \\
\hline Terminalia catappa & Tropical almond \\
\hline Terminalia muelleri & Australian almond \\
\hline Thespesia populnea & Seaside mahoe \\
\hline Tradescantia fluminensis & White-flowered wandering jew \\
\hline Tradescantia spathacea & Oyster plant \\
\hline Tribulus cistoides & Puncture vine \\
\hline Urena lobata & Caesar weed \\
\hline Urochloa mutica & Buffalo grass \\
\hline Vernicia fordii & Tungoil tree \\
\hline Wedelia trilobata & Wedelia \\
\hline Wisteria sinensis & Chinese wisteria \\
\hline Xanthosoma sagittifolium & Elephant ear \\
\hline \hline \multicolumn{2}{|l|}{} \\
\hline \hline
\end{tabular}

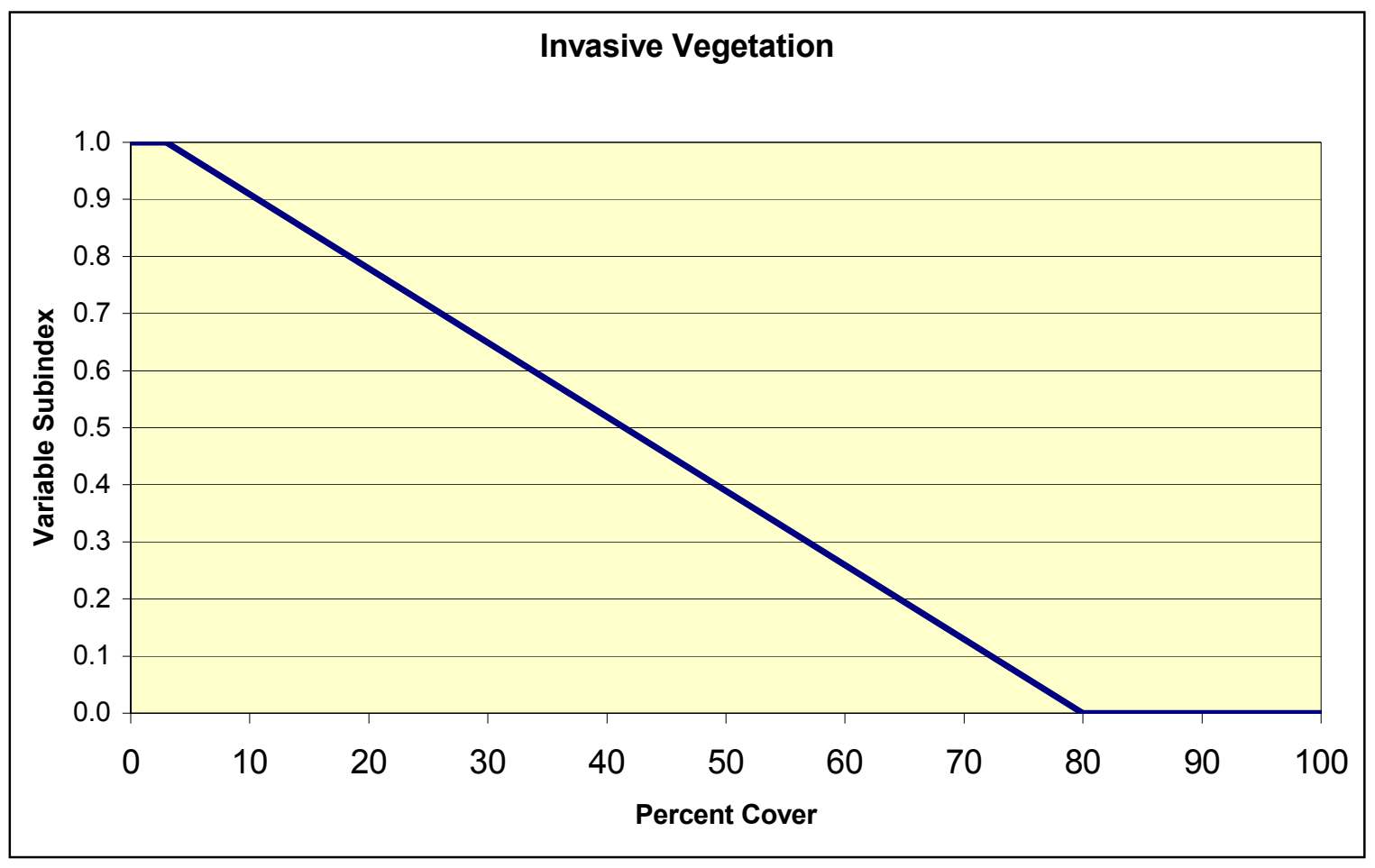

Figure 31. Relationship between percent cover of invasive vegetation and functional capacity

Plant species composition $\left(\boldsymbol{V}_{\text {СомP }}\right)$. Plant species composition represents the dominance of certain native wetland plants in proportion to sites representing those with the least disturbance in the Everglades. Ideally, plant species composition would be determined with intensive sampling of herbaceous species. Unfortunately, the time and taxonomic expertise required to accomplish this are not available in the context of rapid assessment. Thus, the focus here is on the dominant species in the herbaceous strata. 


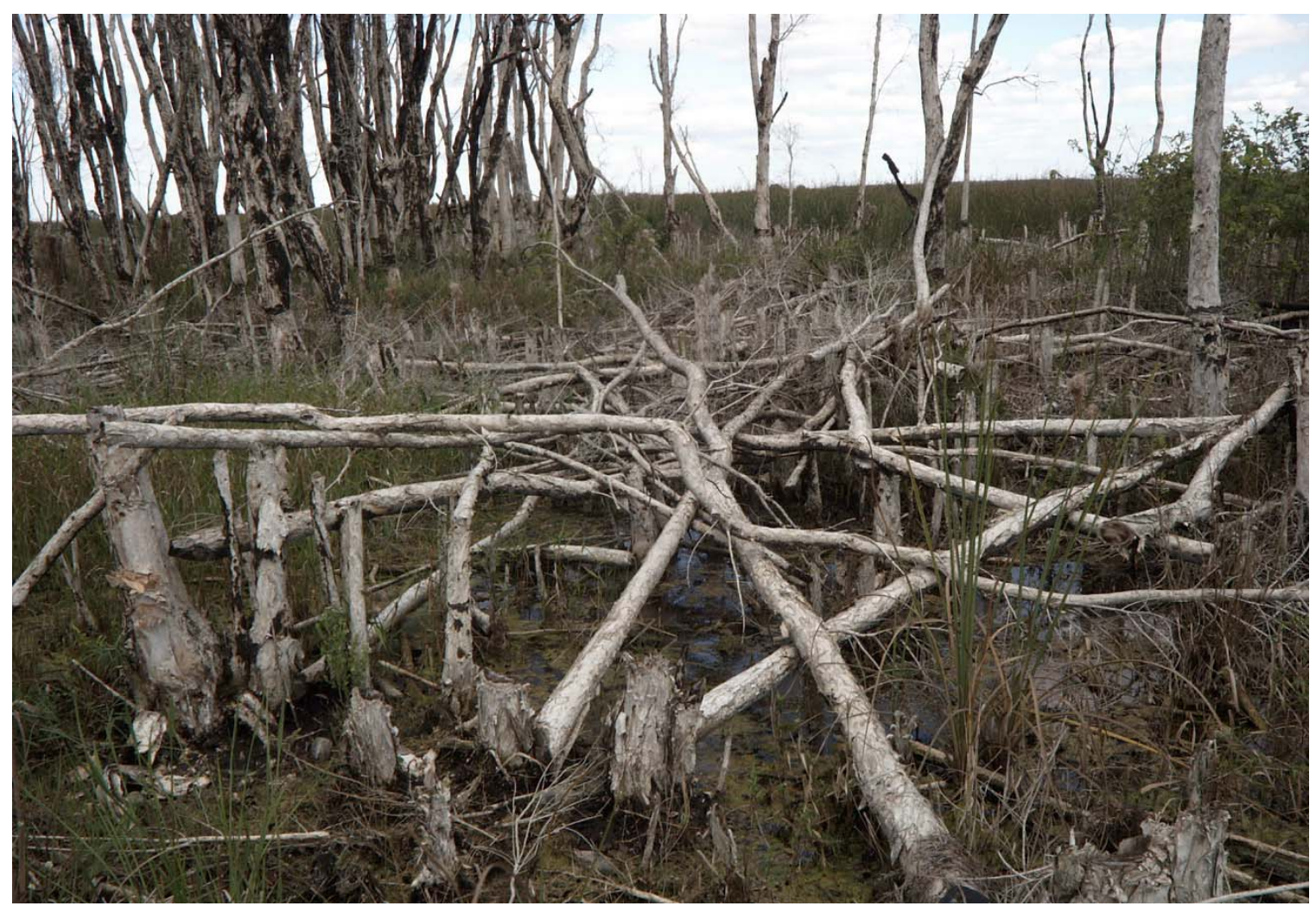

Figure 32. Removal of Melaleuca quinquenervia (melaleuca) as part of wetland restoration. Melaleuca is one of the most invasive species impacting the Everglades

Percent concurrence with the dominant species in the herbaceous stratum is used to quantify this variable. Measure it with the following procedure:

(1) Identify the dominant species in the ground vegetation strata using the $50 / 20$ rule. ${ }^{1}$ To apply the 50/20 rule, rank species from the herbaceous stratum in descending order of abundance. Identify dominants by summing the relative abundances beginning with the most abundant species in descending order until 50 percent is exceeded. Additional species with $\geq 20$ percent relative abundance should also be considered as dominants. If no species is equal to or greater than 20 percent, then identify the species with the greatest percent cover. Accurate species identification is critical for determining the dominant species in each plot. Sampling during the dormant season or after a fire may require a high degree of proficiency. Users who do not feel confident in identifying herbaceous plant species should get help with plant identification.

(2) Calculate percent concurrence by comparing the list of dominant plant species to the list of dominant species in reference standard wetlands

\footnotetext{
${ }^{1}$ Memorandum, 6 March 1992, Office, Chief of Engineers, Clarification of Use of the 1987 Delineation Manual.
} 
(Table 17 or Table 18). For example, if all the dominants from the area being assessed occur on the list of dominants from reference standard wetlands, then there is 100 percent concurrence. If three of the five dominant species from the area being assessed occur on the list, then there is a 60 percent concurrence.

(3) Report concurrence of species dominants as a percent.

In the Everglades reference wetlands, percent concurrence with dominant species ranged from 0 to 100 percent (Appendix D). Based on the data from reference standard sites, a variable subindex of 1.0 is assigned when concurrence with dominant species is 100 percent for a wetland subclass (Figure 33). As percent concurrence decreases, a linearly decreasing subindex down to zero is assigned based on the assumption that the relationship between plant species composition and the capacity of Everglades wetlands to maintain a characteristic plant community is linear (Figure 34).

\begin{tabular}{|c|c|}
\hline \multicolumn{2}{|c|}{$\begin{array}{l}\text { Table } 17 \\
\text { Dominant Plant Species, Marl Flats }\end{array}$} \\
\hline Scientific Name & Common Name \\
\hline Andropogon glomeratus & Bushy bluestem \\
\hline Bacopa caroliniana & Blue waterhyssop \\
\hline Cladium jamaicense & Saw grass \\
\hline Crinum americanun & Seven sisters \\
\hline Eragrostis refracta & Coastal lovegrass \\
\hline Hyptis alata & Clustered bushmint \\
\hline Mikania scandens & Climbing hempweed \\
\hline Muhlenbergia capillaris & Muhly grass \\
\hline Panicum tenerum & Bluejoint panic grass \\
\hline Paspalum monastachyum & Gulfdune paspalum \\
\hline Pluchea rosea & Rosy camphorweed \\
\hline Proserpinaca palustris & Marsh mermaid weed \\
\hline Rhynchospora divergens & Spreading beaksedge \\
\hline Rhynchospora microcarpa & Southern beaksedge \\
\hline Rhynchospora tracyi & Tracy's beaksedge \\
\hline Schizachyrium rhizomatum & Florida little bluestem \\
\hline Spartina alterniflora & Smooth cordgrass \\
\hline Utricularia purpurea & Eastern purple bladderwort \\
\hline
\end{tabular}

\begin{tabular}{||l|l||}
\hline \hline \multicolumn{2}{||l||}{$\begin{array}{l}\text { Table } 18 \\
\text { Dominant Plant Species, Organic Flats }\end{array}$} \\
\hline \hline Scientific Name & Common Name \\
\hline \hline Bacopa caroliniana & Blue waterhyssop \\
\hline Cladium jamaicense & Saw grass \\
\hline Eleocharis cellulosa & Coastal spikerush \\
\hline Eleocharis elongata & Slim spikerush \\
\hline Panicum hemitomon & Maiden cane \\
\hline Peltandra virginica & Green arrow arum \\
\hline Polygonum hydropiperoides & Swamp smartweed \\
\hline Pontederia cordata & Pickerelweed \\
\hline Sagittaria lanceolata & Bulltongue arrowhead \\
\hline Utricularia foliosa & Leafy bladderwort \\
\hline Utricularia purpurea & Eastern purple bladderwort \\
\hline \hline
\end{tabular}




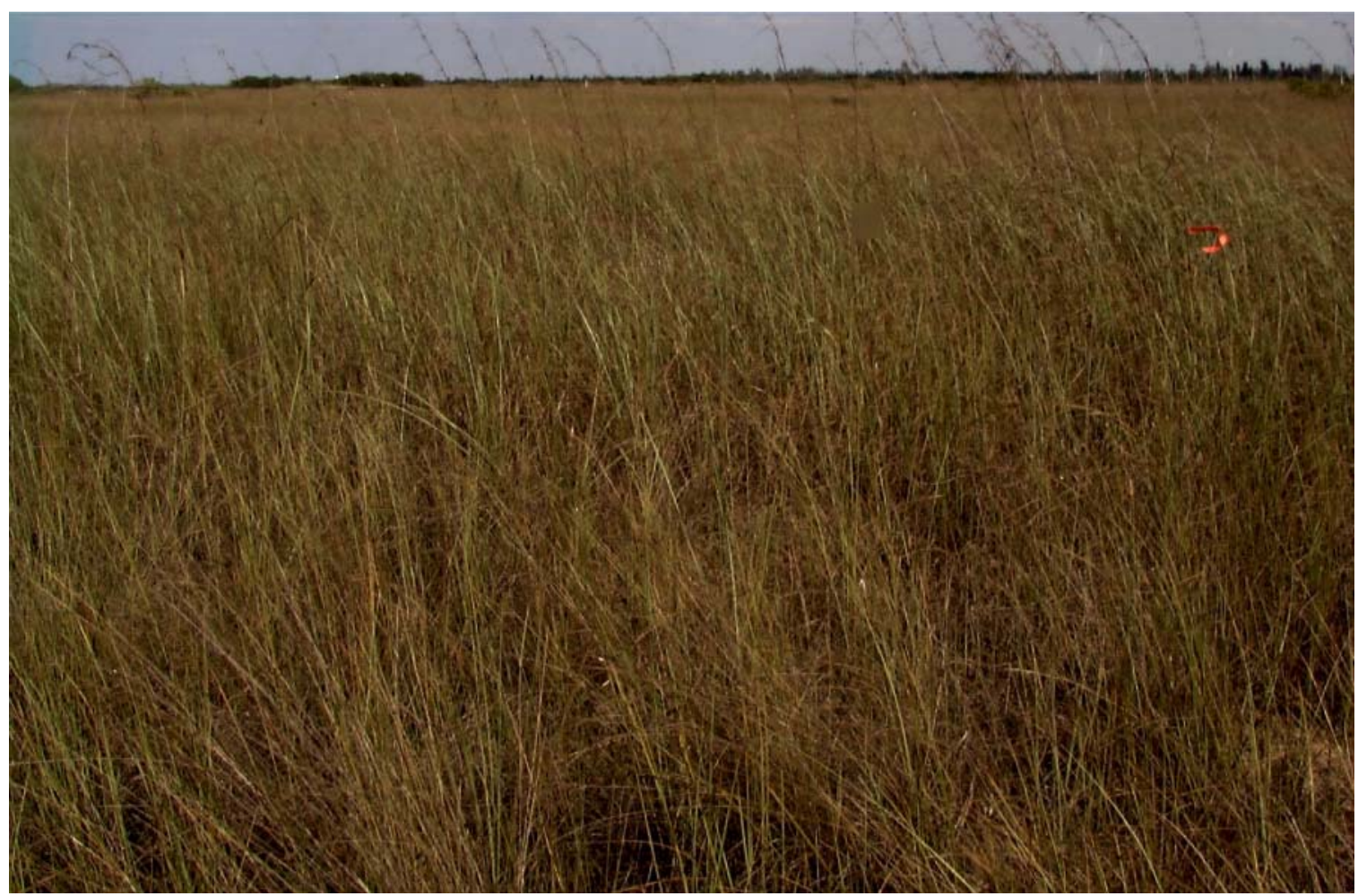

Figure 33. Reference standard Marl Flats Everglades wetland dominated by Cladium jamaicense (saw grass), Spartina alterniflora (smooth cordgrass), Rhynchospora tracyi (Tracy's beaksedge), and Utricularia purpurea (eastern purple bladderwort)

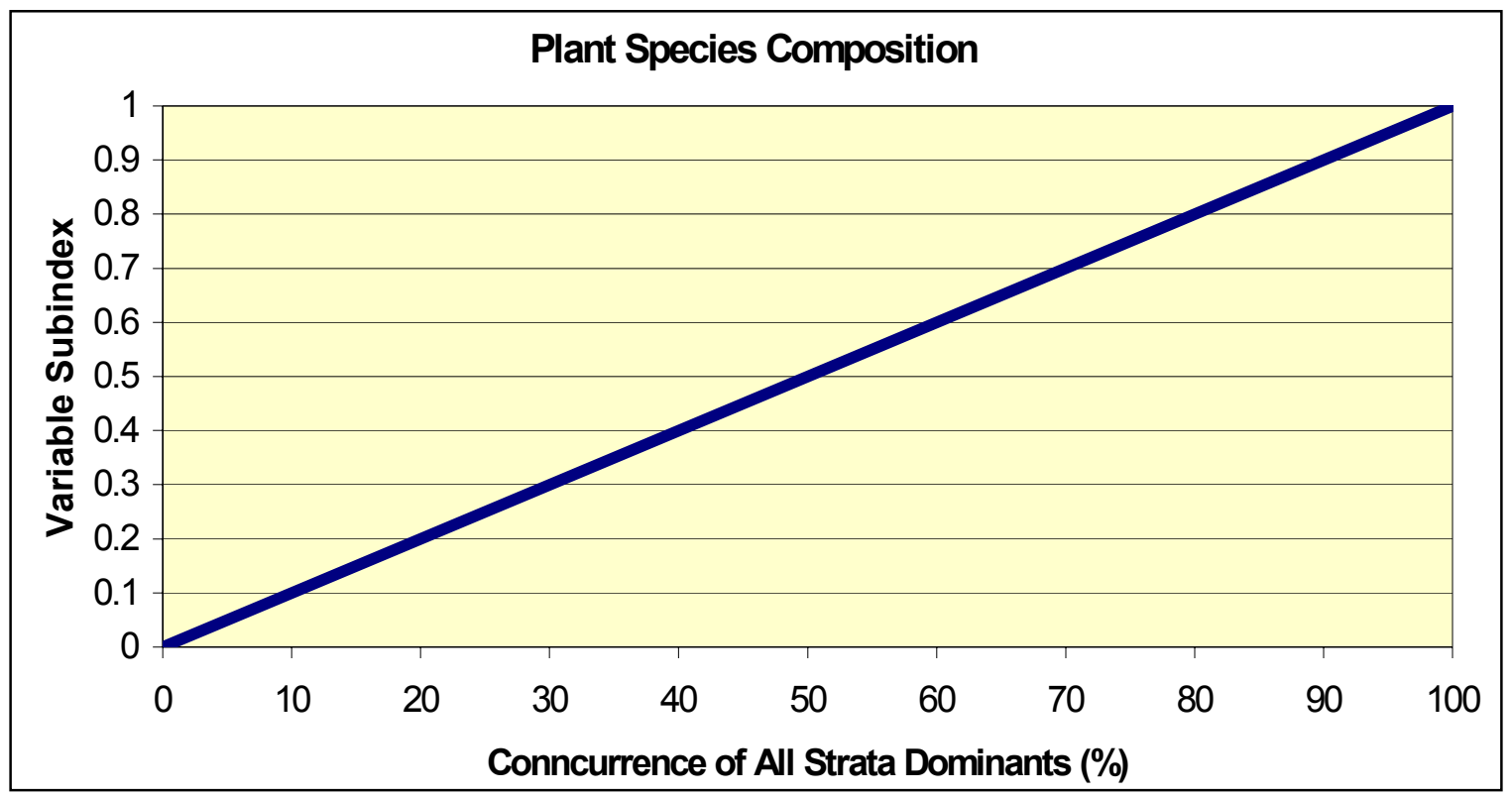

Figure 34. Relationship between percent concurrence of strata dominants and functional capacity 
Number of Native Wetland Species $\left(\boldsymbol{V}_{\text {NATIVE }}\right)$. This variable represents the number of native wetland species that occur on a site in the Rocky Flats Everglades ecosystem. In general, Rocky Everglades wetlands support over 100 native wetland species (Lodge 1994). Disturbed sites usually have fewer native wetland species than undisturbed sites to the point that sites can become dominated by one or two species. Ideally, number of native wetland species would be determined with intensive sampling over the entire site. Unfortunately, the time required is not practical for a rapid assessment. This variable is determined using the following procedure:

(1) During field reconnaissance and plot and subplot sampling, count each native vegetative species that has a Wetland Indicator Status of FAC, FACW, or OBG in each strata (Table 19). Add the number of native wetland species from each vegetative strata and report the total number of native wetland species. Users do not need to determine the taxonomic classification of each species, but must be able to recognize those species that are not native to Florida and are not typically found in wetlands. Users who do not feel confident in making these identifications should get help with plant identification.

(2) Using Table 19, assign a variable subindex score.

\begin{tabular}{|c|c|}
\hline \multicolumn{2}{|c|}{$\begin{array}{l}\text { Table } 19 \\
\text { Number of Native Wetland Species in Rocky Flats Everglades } \\
\text { Wetlands }\end{array}$} \\
\hline Number of Species & Subindex Score \\
\hline$\geq 20$ & $\begin{array}{ll}1.0 \\
\end{array}$ \\
\hline 19 & 0.95 \\
\hline 18 & 0.9 \\
\hline 17 & 0.85 \\
\hline 16 & 0.8 \\
\hline 15 & 0.75 \\
\hline 14 & \begin{tabular}{|l|l|}
0.7 \\
\end{tabular} \\
\hline 13 & 0.65 \\
\hline 12 & 0.6 \\
\hline 11 & 0.55 \\
\hline 10 & \begin{tabular}{|l|}
0.5 \\
\end{tabular} \\
\hline 9 & 0.45 \\
\hline 8 & 0.4 \\
\hline 7 & 0.35 \\
\hline 6 & 0.3 \\
\hline 5 & 0.25 \\
\hline 4 & 0.20 \\
\hline 3 & \begin{tabular}{|l|}
0.1 .5 \\
\end{tabular} \\
\hline 2 & \begin{tabular}{|l|}
0.1 \\
\end{tabular} \\
\hline 1 & 0.05 \\
\hline 0 & 0 \\
\hline
\end{tabular}

In the Rocky Flats Everglades reference wetlands the number of native wetland species ranged from 3 to 39 (Appendix D). Based on the data from reference standard sites, a variable subindex score would be assigned when the 
number of native wetland species is 15 or greater. As the number of species decreases, a linearly decreasing subindex down to zero is assigned based on the assumption that the relationship between the number of native wetland species and the capacity of Rocky Flats Everglades wetlands to maintain a diverse native wetland plant community is linear.

Surface Soil Texture ( $\left.V_{\text {SURTEX }}\right)$. This variable is defined as the USDA soil texture of the surface horizon or layer of the soil. Soil is the medium on which and in which water is stored. Altering the texture of the soil through anthropogenic activities (e.g., fill, excavation, rock plowing) changes the capacity of water storage and other factors affecting plant growth. Soil alterations also change the physical features to which native plants have adapted. This variable is determined with the following procedure:

(1) Estimate the texture class of the surface horizon using the feel method in or adjacent to each of the three $1-\mathrm{m}^{2}(3.3-\mathrm{ft})$ subplots. Appendix C describes the procedure for estimating texture by class using the feel method.

(2) Using Table 20 or Table 21, assign a score for each texture class found.

(3) Determine a subindex score by averaging the score from all of the subplots.

Soil texture in the Everglades ranged from marl or muck to gravel. Based on reference standard sites, textures were marl for Rocky and Marl Flats sites and muck for Organic Flats sites. Other USDA textural classes received categorically lower subindex scores down to zero for gravel, bedrock, and pavement

(Figure 35).

\begin{tabular}{|c|c|}
\hline \multicolumn{2}{|c|}{$\begin{array}{l}\text { Table } 20 \\
\text { Soil Surface Texture for Rocky and Marl Flats Everglades } \\
\text { Wetlands }\end{array}$} \\
\hline Soil Texture & Score \\
\hline 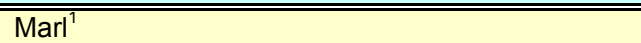 & 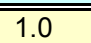 \\
\hline Muck $^{1}$ & 0.8 \\
\hline Silt & 0.9 \\
\hline Silt loam & 0.9 \\
\hline Loam & 0.5 \\
\hline Gravelly silt loam ( $15 \%$ to $<35 \%$ gravel) & 0.4 \\
\hline Gravelly silt $(15 \%$ to $<35 \%$ gravel) & 0.4 \\
\hline Very gravelly silt loam (35\% to $<60 \%$ gravel) & 0.3 \\
\hline Very gravelly silt ( $35 \%$ to $<60 \%$ gravel) & 0.3 \\
\hline Sandy loam & 0.2 \\
\hline Clay & 0.2 \\
\hline Sand & 0.2 \\
\hline Loamy sand & 0.2 \\
\hline Extremely gravelly silt loam $(60 \%$ to $<90 \%$ gravel $)$ & 0.2 \\
\hline Extremely gravelly silt $(60 \%$ to $<90 \%$ gravel) & 0.2 \\
\hline Gravel $^{1}(\geq 90 \%$ gravel) & 0.1 \\
\hline Rock & 0.0 \\
\hline Pavement $^{1}$ & 0.0 \\
\hline
\end{tabular}




\begin{tabular}{|c|c|}
\hline \multicolumn{2}{|c|}{$\begin{array}{l}\text { Table } 21 \\
\text { Soil Surface Texture for Organic Flats Everglades Wetlano }\end{array}$} \\
\hline Soil Texture & Score \\
\hline Muck ${ }^{1}$ & 1.0 \\
\hline Marl $^{1}$ & 0.8 \\
\hline Silt & 0.9 \\
\hline Silt loam & 0.9 \\
\hline Loam & 0.5 \\
\hline Gravelly silt loam ( $15 \%$ to $<35 \%$ gravel) & 0.4 \\
\hline Gravelly silt $(15 \%$ to $<35 \%$ gravel) & 0.4 \\
\hline Very gravelly silt loam $(35 \%$ to $<60 \%$ gravel) & 0.3 \\
\hline Very gravelly silt ( $35 \%$ to $<60 \%$ gravel) & 0.3 \\
\hline Sandy loam & 0.2 \\
\hline Clay & 0.2 \\
\hline Sand & 0.2 \\
\hline Loamy sand & 0.2 \\
\hline Extremely gravelly silt loam $(60 \%$ to $<90 \%$ gravel) & 0.2 \\
\hline Extremely gravelly silt $(60 \%$ to $<90 \%$ gravel) & 0.2 \\
\hline 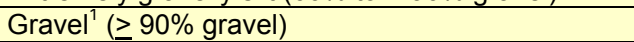 & 0.1 \\
\hline Rock & 0.0 \\
\hline Pavement ${ }^{1}$ & 0.0 \\
\hline
\end{tabular}

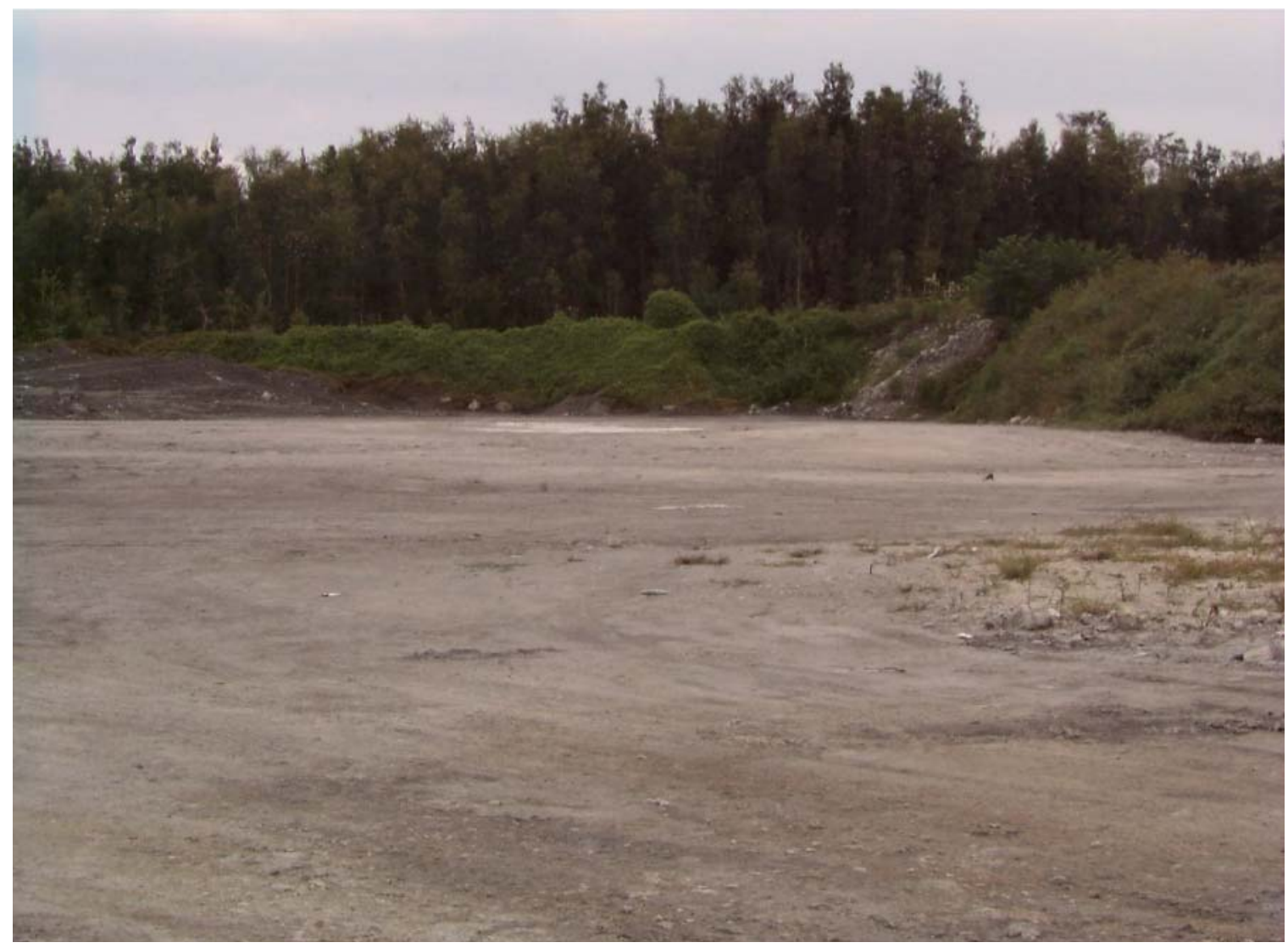

Figure 35. Surface soil texture of rock due to scraping and removal of the natural organic soil 
Soil Thickness ( $\left.V_{\text {sогтніск }}\right)$. This variable, which represents the total thickness of the soil over limestone rock in the Rocky Flats Everglades wetlands, is defined as the average soil thickness within multiple plots, exclusive of solution holes. The depth or thickness of soil in the Rocky Flats Everglades is shallow to very shallow. An increase in the average soil thickness indicates disturbances such as the addition of fill material or rock plowing. These impacts affect the physical and hydrologic characteristics maintaining the characteristic plant community.

Thickness of the soil is used to quantify this variable. Measure it using the following procedure:

(1) Measure the total marl soil depth to limestone outside of solution holes in each of three $1-\mathrm{m}^{2}\left(3.3-\mathrm{ft}^{2}\right)$ subplots.

(2) Average the thickness from all of the subplots.

(3) Report soil thickness in centimeters.

(4) Using Figure 36, determine the subindex score for soil thickness in Rocky Flats Everglades wetlands.

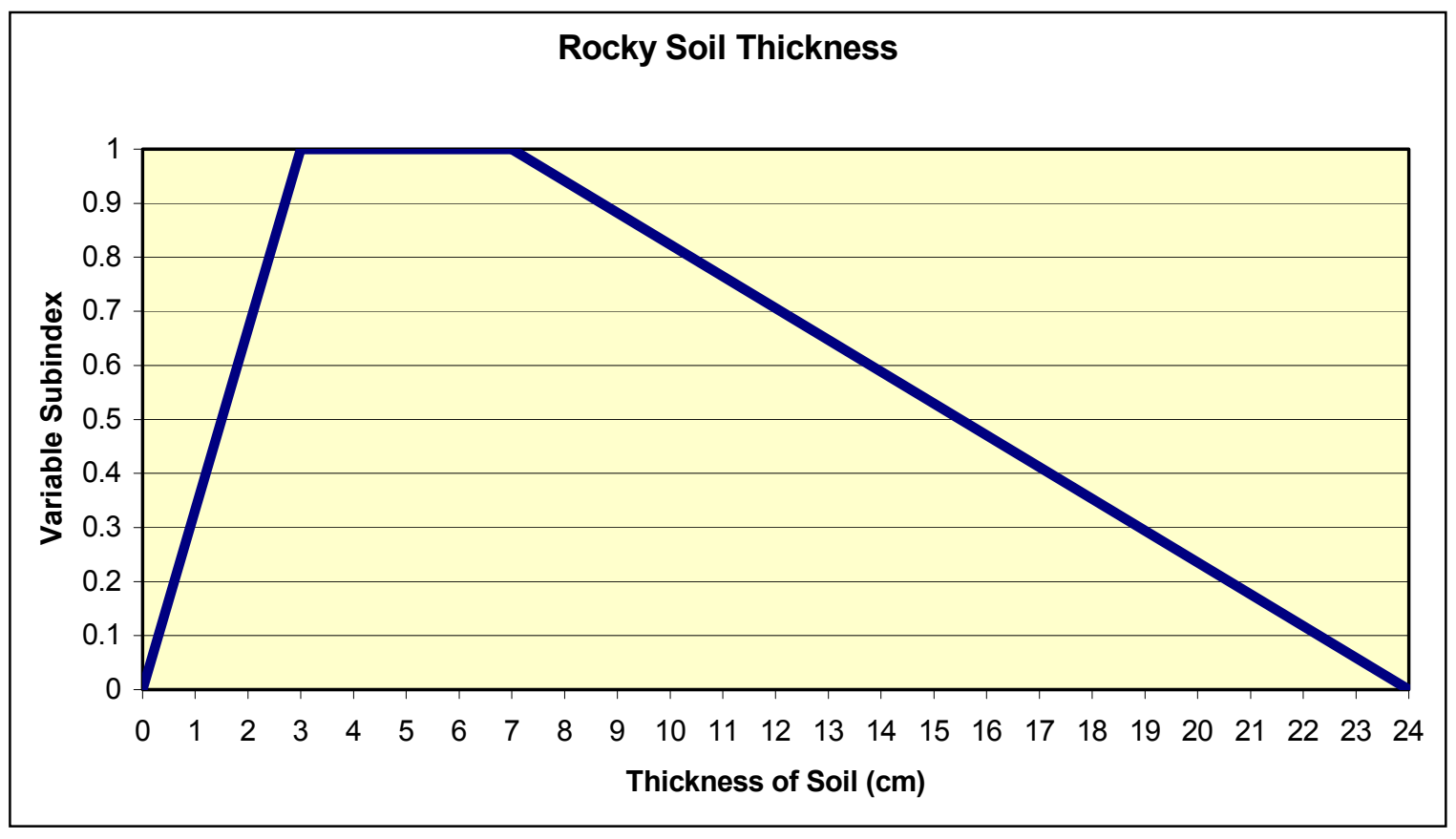

Figure 36. Relationship between soil thickness and functional capacity

In the Everglades wetlands, this variable is applicable only to the Rocky Flats subclass. In the Everglades reference wetlands, soil thickness ranged from 0 to $32 \mathrm{~cm}$ for Rocky Flats wetlands. Based on data from reference standard wetlands sites, a variable subindex of 1.0 is assigned to sites with soil thickness between 3 and $7 \mathrm{~cm}$ for Rocky Flats wetlands. As soil thickness decreases below 
$3 \mathrm{~cm}$ or increases above $7 \mathrm{~cm}$ for Rocky Flats wetlands, a linearly decreasing subindex score down to zero is assigned for Rocky Flats sites at $0 \mathrm{~cm}$ and $24 \mathrm{~cm}$ total soil thickness. This is based on the assumption that the soil thickness is related to excavation or filling activities to the point that the site is no longer inundated or saturated under normal conditions. These assumptions could be validated using the independent, quantitative measures of function defined in the previous paragraph.

Microtopographic Features ( $\left.\boldsymbol{V}_{\text {MICRo }}\right)$. This variable represents the occurrence of microtopographic features in the Everglades wetland ecosystem. Microtopographic features are defined as small topographic changes in elevation, often less than $1 \mathrm{~cm}$, over short distances usually less than $1 \mathrm{~m}$. Altering the microtopographic features of the landscape through anthropogenic activities (e.g., fill, excavation, rock plowing, land leveling, bedding) changes the water storage capability of the soil and habitat characteristics for plants. This variable is determined with the following procedure:

(1) Determine if any of the WAA or PWAA has been altered by bedding, rock plowing, land leveling, or other activity that has altered the microtopographic features.

(2) If no altered areas exist, assign a value of 1.0. This indicates that the microtopography in the assessment area is similar to reference standard sites.

(3) If areas with altered microtopographic exist, determine what percent of the area has altered microtopography. Using Table 22, assign a subindex score for each alteration found.

(4) Report the percent of the WAA or PWAA with altered microtopography.

(5) Using a weighted average of the subindex score and percent area of each microtopographic feature, determine the subindex score for the WAA or PWAA.

\section{Table 22 \\ Microtopographic Features}

\begin{tabular}{||l|l|}
\hline \hline Alteration Category & Variable Subindex \\
\hline \hline Rock plowing & 0.0 \\
\hline Land leveling & 0.1 \\
\hline Bedding & 0.2 \\
\hline Unaltered & 1.0 \\
\hline
\end{tabular}

Microtopographic features in the Everglades were either 0 or 100 percent. The most significant topographic change in the Rocky Flats subclass is rock plowing. This mechanical scarifying of the landscape to create a soil deep enough to plant crops drastically alters the microtopographic features of this subclass to the point that restoration of this variable is impossible. In the Marl Flats subclass land leveling and bedding are the most significant impact on 
microtopographic features. However, the effects are completely opposite. Land leveling is the alteration of the landscape to remove the microtopographic features to improve surface drainage. Bedding is the practice of mounding the soil in rows to raise the root zone above the water table. This practice is usually used for ornamental nursery stock or fruit trees in the Marl Flats subclass.

Unlike rock plowing, the site microtopographic features could be returned to some resemblance of predisturbance condition for areas that have been landleveled or bedded. The Organic Flats subclass is most impacted by land leveling from the standpoint of microtopographic features. Restoration potential would be similar to Marl Flats sites for this variable.

\section{Functional Capacity Index}

The assessment models for calculating the FCI are as follows:

a. For Rocky Flats Everglades wetlands

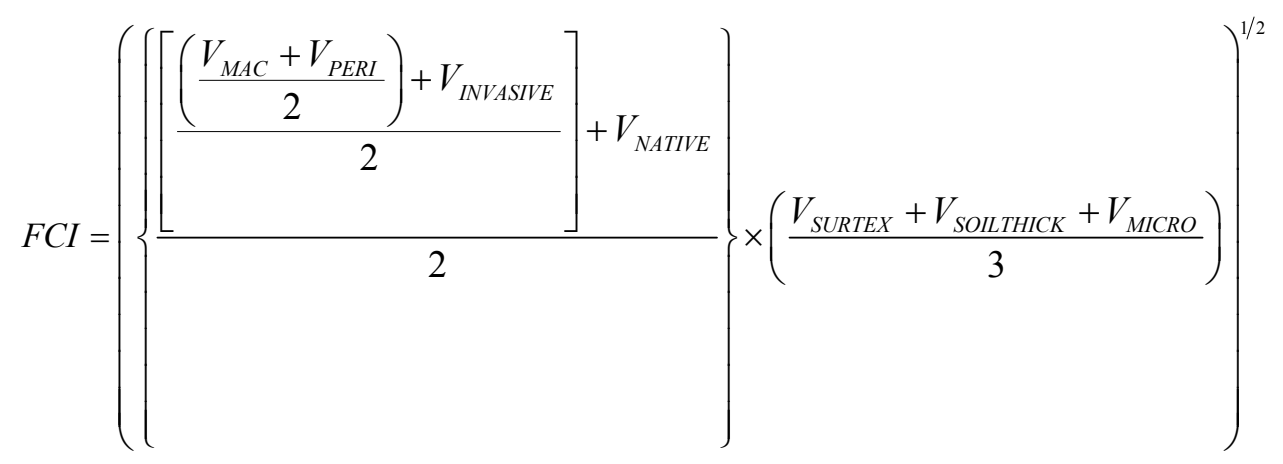

b. For Marl Flats Everglades wetlands

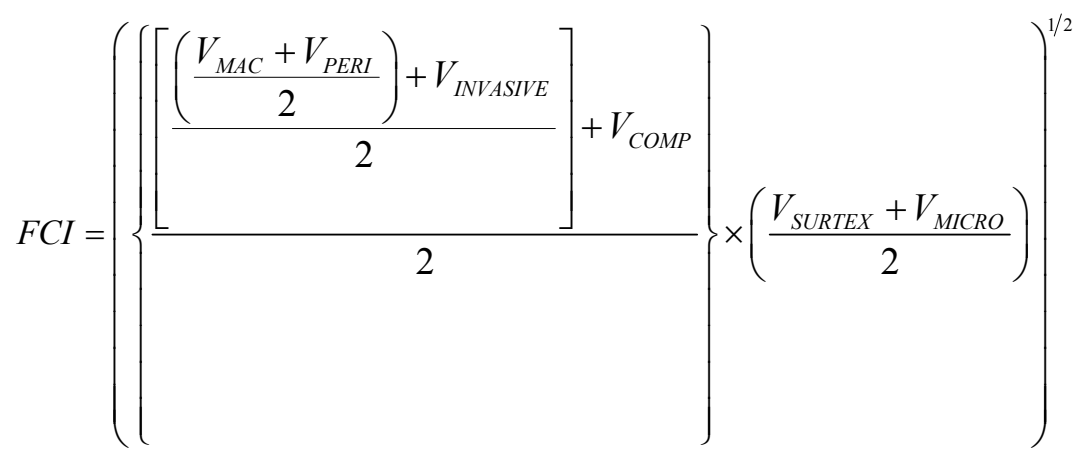

c. For Organic Flats Everglades wetlands 


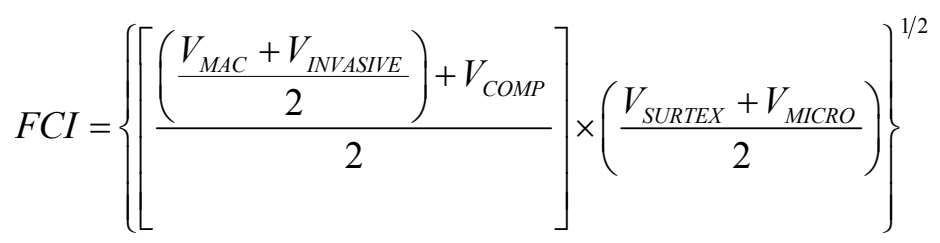

In each of these models the capacity of Everglades wetlands to maintain a characteristic plant community is dependent on the existing vegetation and soils. Rocky and Marl Flats Everglades wetlands models average the percent cover of macrophytic vegetation $\left(V_{M A C}\right)$ and periphyton $\left(V_{P E R I}\right)$. This assumes that these two variables are of equal importance to the plant community. The result of the combination of $V_{M A C}$ and $V_{P E R I}$ is averaged with percent cover of invasive vegetation $\left(V_{I N V A S I V E}\right)$. This combination weights $V_{I N V A S I V E}$ and assumes that invasive vegetation is as important as $V_{M A C}$ and $V_{P E R I}$ combined. Plant species composition in the form of number of native wetland species $\left(V_{\text {NATIVE }}\right.$ or $\left.V_{C O M P}\right)$ is averaged with the result of the average of $V_{\text {MAC }}, V_{\text {PERI }}$, and $V_{\text {INVASIVE. This }}$ combination adds greater weight to plant species composition.

The model for the Organic Flats subclass averages $V_{M A C}$ with $V_{I N V A S I V E}$ because $V_{P E R I}$ does not apply to this subclass. The result is averaged with $V_{C O M P}$ and weights plant species composition equally with the result of $V_{M A C}$ and $V_{\text {INVASIVE. }}$

The second part of the models averages the soil components surface texture of the soil $\left(V_{\text {SURTEX }}\right)$ and microtopographic relief $\left(V_{\text {MICRO }}\right)$ for Marl and Organic Flats subclasses as well as soil thickness $\left(V_{\text {SOILTHICK }}\right)$ for Rocky Flats Everglades wetlands. Soils are averaged separately on the basis of current conditions and potential for restoration. If percent vegetative cover and species diversity are appropriate for the subclass, then the soils have not been impacted to a degree that vegetation cannot be restored to near reference standard conditions. However, depending on the severity of soil impacts, restoration may not be possible. This combination assumes that each of these variables is of equal importance for maintaining a characteristic plant community.

The two parts of the equations are averaged using a geometric mean based on the assumption that both structure and species composition and soil factors contribute equally to the maintance of a characteristic plant community. If the subindices for the variables in either part of the model decrease, there will be a reduction in the FCI to zero if either part equals zero.

\section{Function 4: Provide Wildlife Habitat}

\section{Definition}

Provide Wildlife Habitat is defined as the ability of an Everglades wetland to support the wildlife species that use Everglades wetlands during all or part of their life cycles. A potential independent, quantitative measure of this function is 
a similarity index calculated from species composition and abundance (Odum 1950; Sorenson 1948).

\section{Rationale for selecting the function}

Everglades wetlands are used extensively by terrestrial, semiaquatic, and aquatic animals to complete their life histories. The performance of this function ensures habitat for a diversity of invertebrate and vertebrate organisms, contributes to secondary production, maintains complex trophic interactions, and provides access to and from wetlands for completion of aquatic species life cycles. Performance of this function also provides refugia and habitat for wideranging or migratory birds and conduits for dispersal of species to other areas. Habitat requirements for individual species and even groups of similar species sometimes are highly specialized; however, most wildlife and fish species found in Everglades Flats depend on certain common characteristics such as hydroperiod, topography, vegetative composition and structure, and proximity to other habitats.

\section{Characteristics and processes that influence the function}

Hydrology in the form of seasonal inundation is one major factor influencing wildlife habitat quality in Everglades Flats wetlands. Periods of inundation are necessary for the growth of periphyton, a blue-green algae, which along with detritus from macrophytic vegetation forms the bases of the food web (Browder, Gleason, and Swift 1994). It has been determined that roughly half of the diet of crayfish is algae, the remainder consisting of higher plant detritus (Bennetts, Callopy, and Rogers 1994). Periphyton is a critical winter food source for mosquitofish (Browder, Gleason, and Swift 1994). Apple snails (Pomacea paludosa) (Figure 37) also consume considerable quantities of algae, thereby affecting the populations of an endangered species, the snail kite (Rostrhamus sociabilis) (Bennetts, Callopy, and Rogers 1994).

The Everglades does not support a variety of freshwater invertebrates due to limited habitats and subtropical climate (Lodge 1994). However, many of the species present are unique and locally important as a food source for vertebrate species. The freshwater apple snail, for example, is nearly the exclusive food for the snail kite, a highly specialized raptor (Beissinger 1994). Snail kite foraging habitat is characterized by emergent and open water habitats (Bennetts, Callopy, and Rogers 1994) found in the Rocky, Marl, and Organic Everglades Flats wetlands. Invasive species often develop a dense canopy that would deter feeding.

Wading birds have historically been important consumers of fishes, invertebrates, and anurans in the Everglades ecosystem and are often used as indicators of the health of the system (Ogden 1994). Wood storks (Mycteria americana) feed primarily on small fishes (Ogden, Kushlan, and Tilmant 1976) which become concentrated during the dry season in pools and depressions (Kushlan 1974; Frederick and Spalding 1994). 


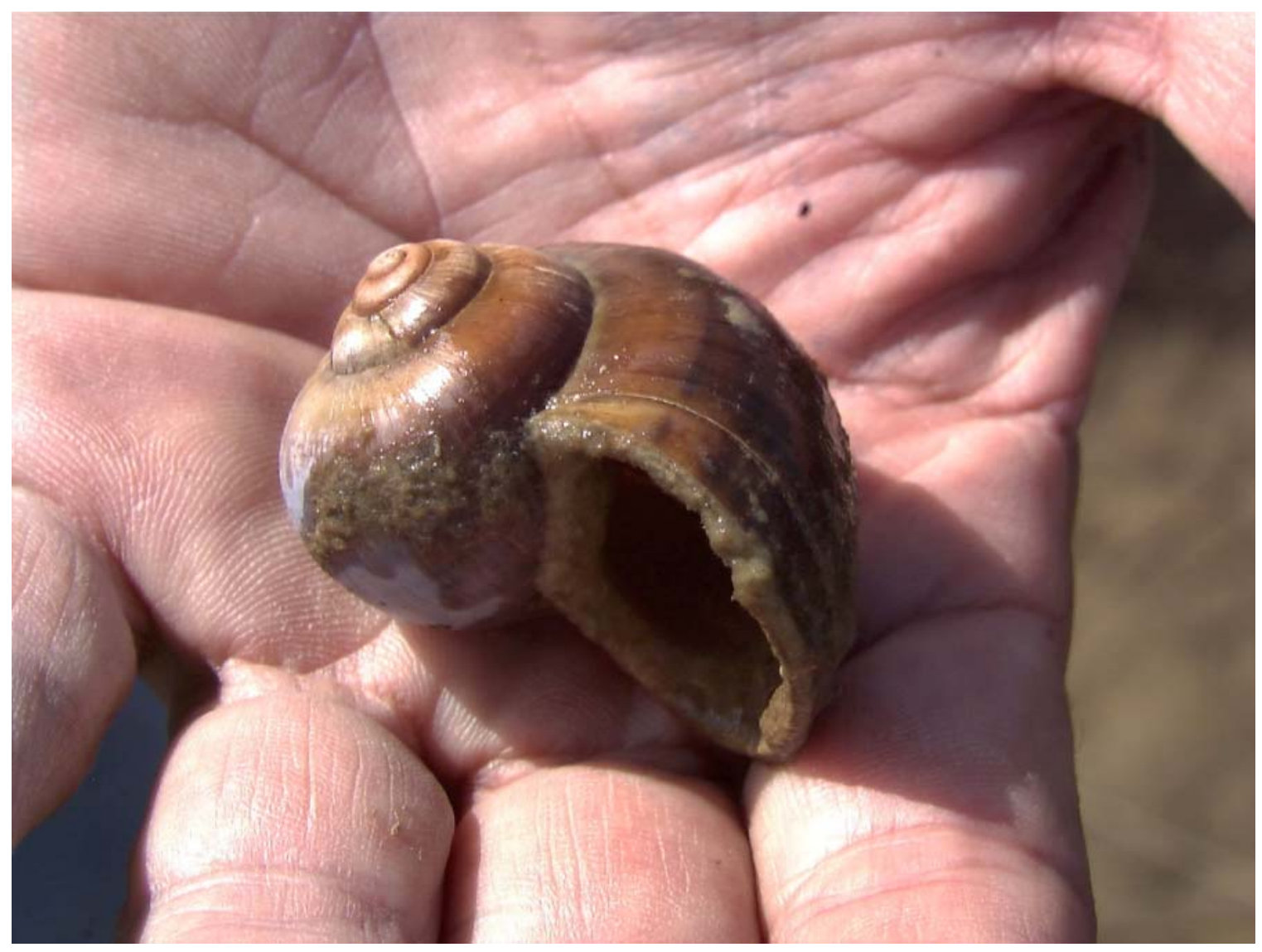

Figure 37. Pomacea paludosa (apple snails) are the primary food of the Rostrhamus sociabilis (snail kite)

Although small invertebrates are the main dietary item of mosquitofish during summer months, algae is the fish's main food source in winter when insects are less available. The biomass of fish in the Everglades ecosystem is quite large and is a primary component in the food chain (Lodge 1994).

The American alligator, Alligator mississippiensis (Figure 38), is a primary symbol of the Everglades (Mazzotti and Brandt 1994). The excavated ponds and trails that alligators create as well as the mounds made in nesting are extremely important to other wildlife species during wet and dry hydrologic cycles.

Many of the concepts regarding these landscape features originated with MacArthur and Wilson's (1967) theory of island biogeography, which states that immigration and extinction rates that control population size are themselves influenced by island size and special considerations. In general, larger islands or tracts that are near a source of colonists support larger, more stable populations. Connection to other wetland habitats as well as upland habitats is critical for many species that use the Everglades wetlands for part of their life cycle. Many animals such as birds can travel several kilometers to feed or nest, but others, such as amphibians, travel only a few meters to other habitats. Habitat features 


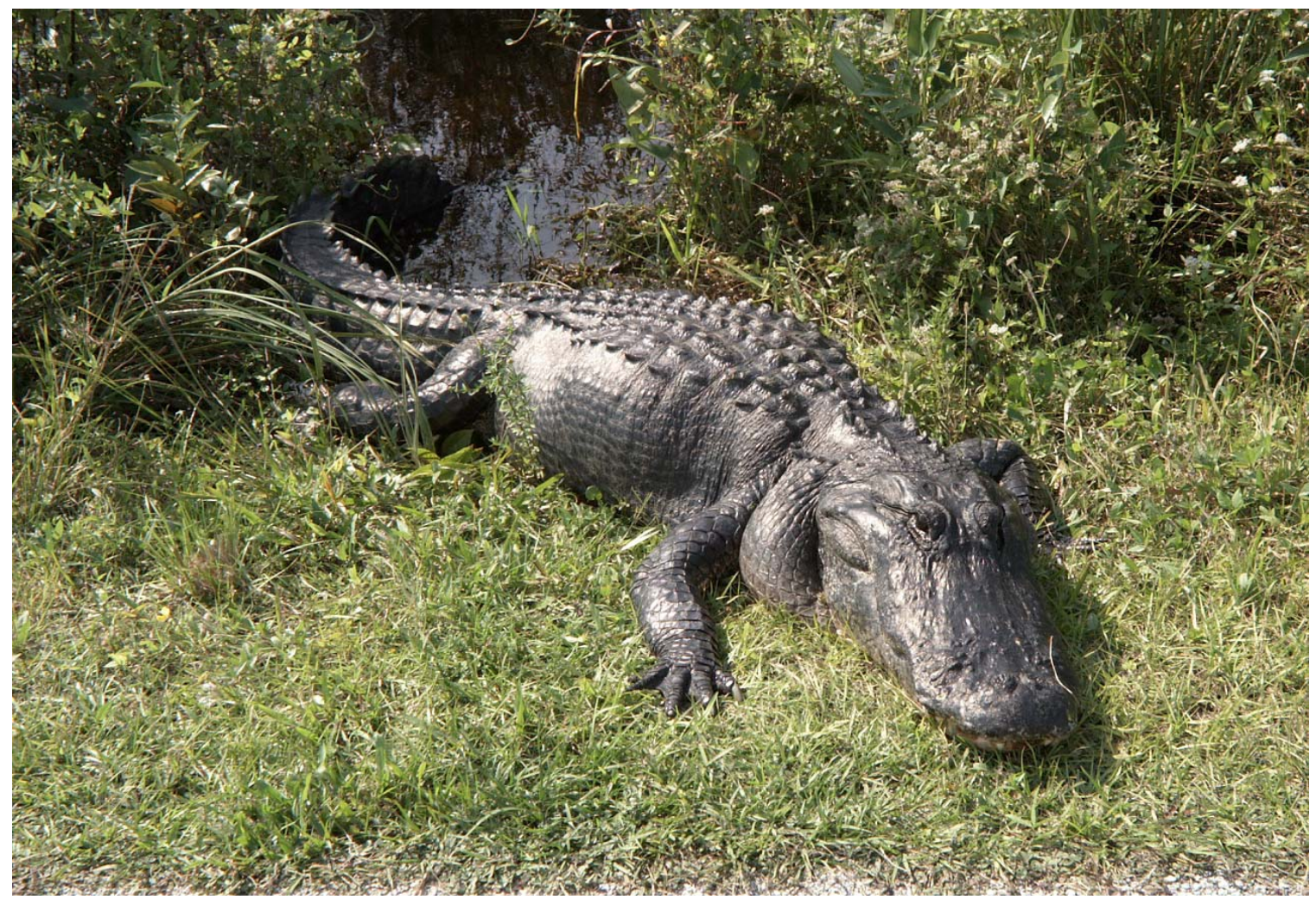

Figure 38. Alligator mississippiensis (American alligator)

occur on many scales within the Everglades ecosystem. Examples of small-scale features are solution holes in the limestone bedrock. Fish, invertebrates, and amphibians as well as the algae that is a food source survive in solution holes during dry periods in the Rocky Flats Everglades. These solution holes also concentrate fish during dry periods, a condition which wading birds need during nesting. Ridges and swales provide the same function for species survival in the Marl and Organic Flats subclasses. Disturbances such as rock plowing or land leveling destroy the microtopography. On the large scale many species present in the Everglades need large areas for foraging.

\section{Description of model variables}

Wetland Tract Area $\left(V_{T R A C T}\right)$. This variable is the area of Everglades flats wetland that is accessible to wildlife from the area being assessed (Figure 39). In the context of this function, this variable represents the fact that wildlife movement is not constrained by imaginary lines on a map such as project boundaries. Although species dependent, wildlife movement is more likely to be constrained by factors such as size of home range; and ecologically meaningful boundaries are more likely to be distinguished by changes in land use, habitat type, or structures such as roads. 


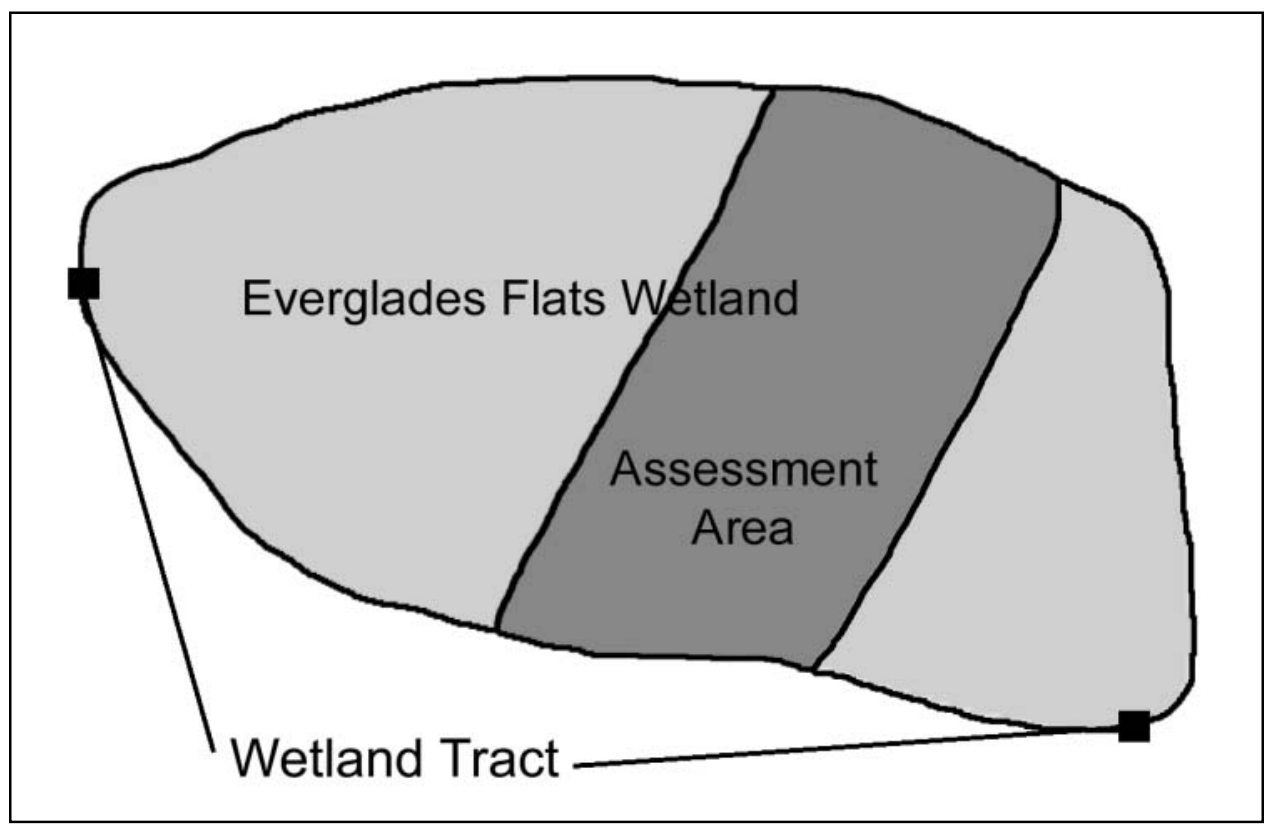

Figure 39. Relationship of assessment area to the larger area of contiguous wetland of the same subclass for determining wetland tract

The area of wetland that is not separated by $50 \mathrm{~m}$ or more of unsuitable habitat from the area being assessed and the same regional wetland subclass is used to quantify this variable. Measure it with the following procedure:

(1) Determine the area of wetland of the same regional wetland subclass that is not separated by a $50-\mathrm{m}$-wide area of unsuitable habitat from the assessment area using recent aerial photography, topographic maps, or National Wetland Inventory maps (NWI). Examples of unsuitable habitat would include, but are not limited to, farmland, upland housing developments, industrial parks, open water, and mined areas. Tree islands should be included with the tract size.

(2) Record the size of the area in hectares.

(3) Verify during field reconnaissance.

(4) Using Figure 40 for Rocky and Marl Flats or Figure 41 for Organic Flats Everglades wetlands, assign a variable subindex score.

In the Everglades reference wetlands, tract size ranged from 0 to more than 173,000 ha (Appendix D). This range assumes that two-lane county roads, narrow canals, and powerline corridors do not represent significant barriers to most wildlife. Larger roads, regional canals, and discontinuities were treated as tract boundaries. Based on data from reference standard sites in the Everglades, a variable subindex of 1.0 is assigned when wetland tract size is $\geq 500$ ha (1,236 acres) for Rocky and Marl Flats Everglades wetlands (Figure 42). 


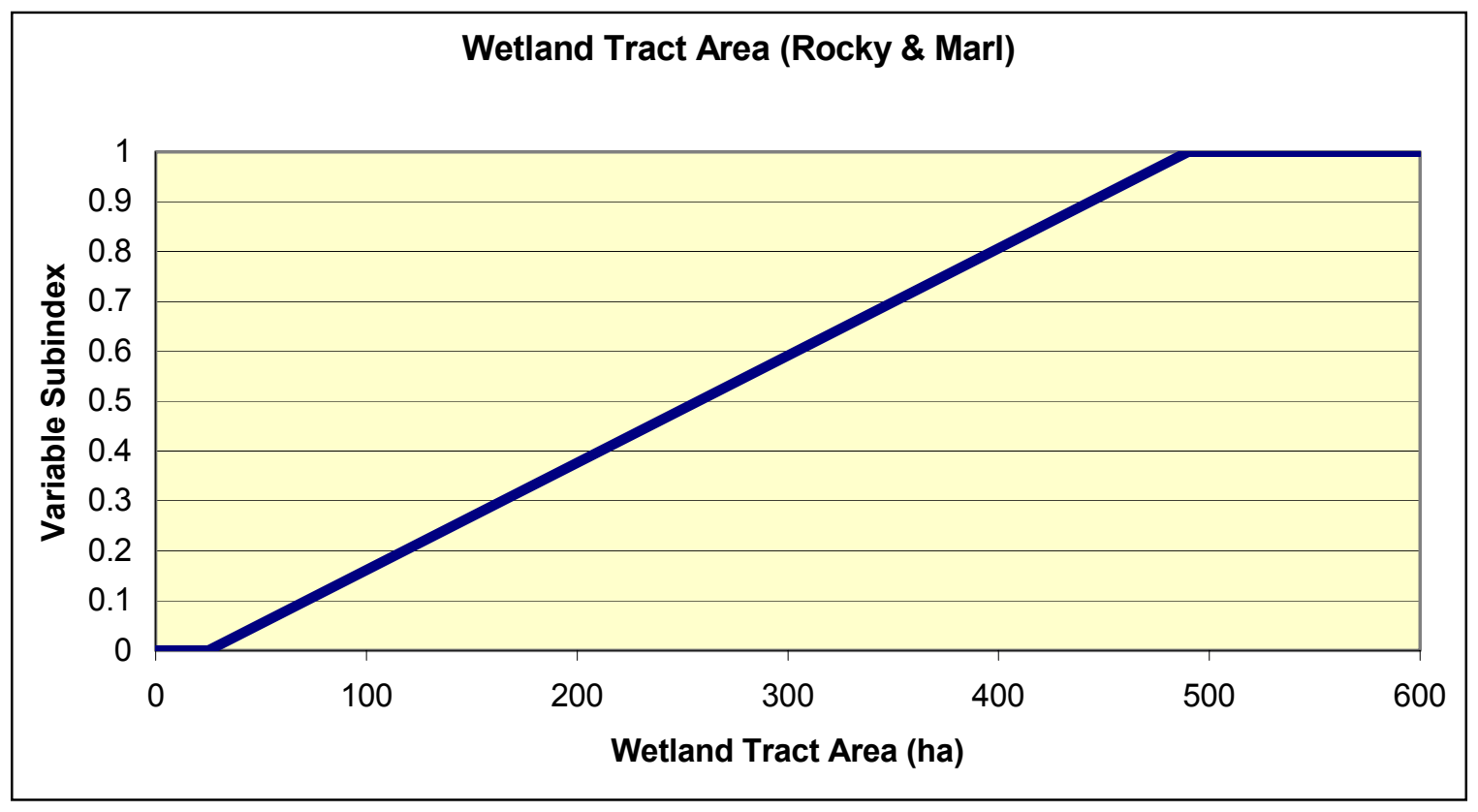

Figure 40. Wetland tract size for Rocky and Marl Flats Everglades wetlands and functional capacity

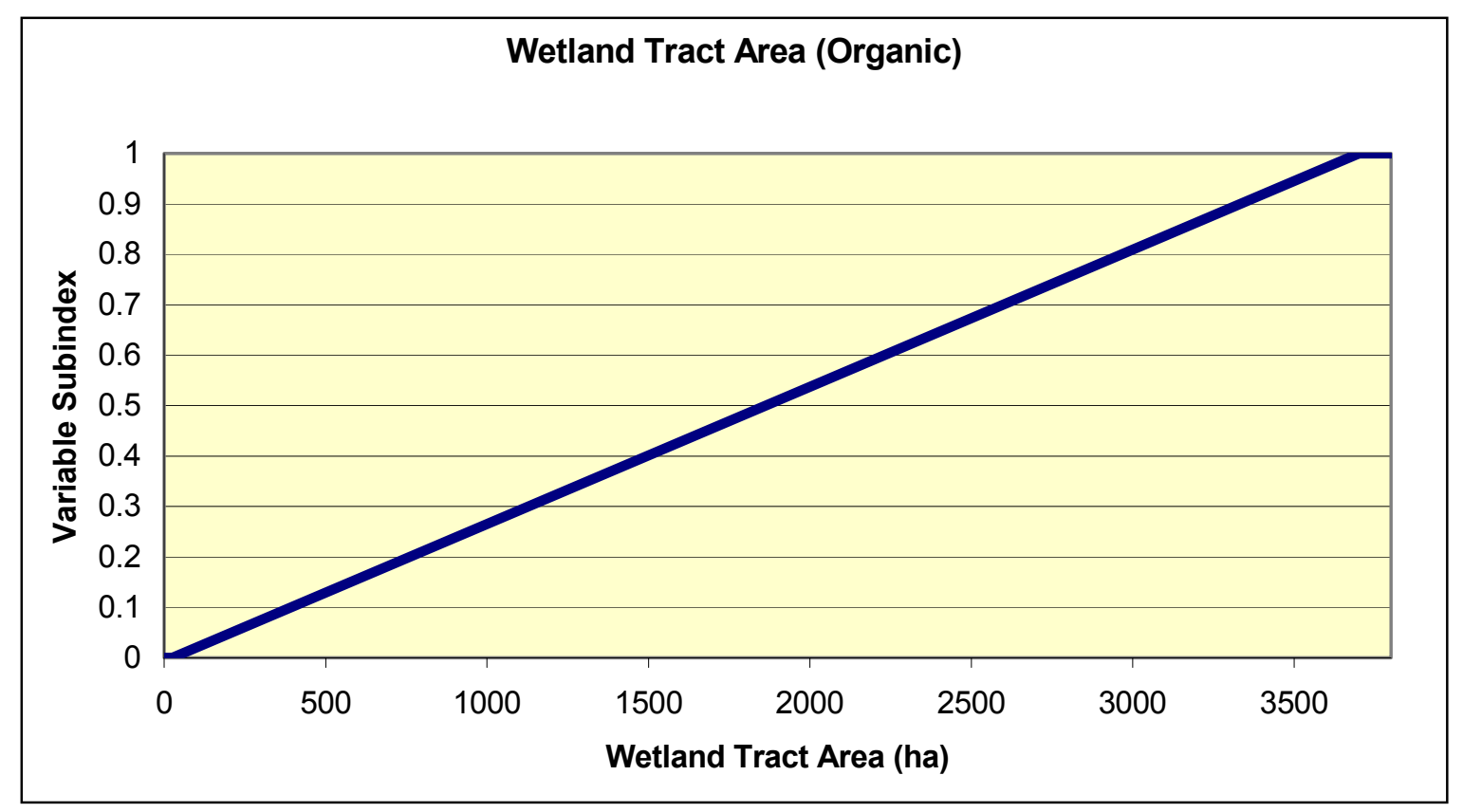

Figure 41. Wetland tract size for Organic Flats Everglades wetlands and functional capacity

Organic Everglades wetlands receive a subindex score of 1.0 when the tract size is $\geq 3,700$ ha $(9,143$ acres) (Figure 43$)$. Wetland tracts less than 25 ha receive a model subindex of 0.0 since they provide virtually no additional area for wildlife habitat. 


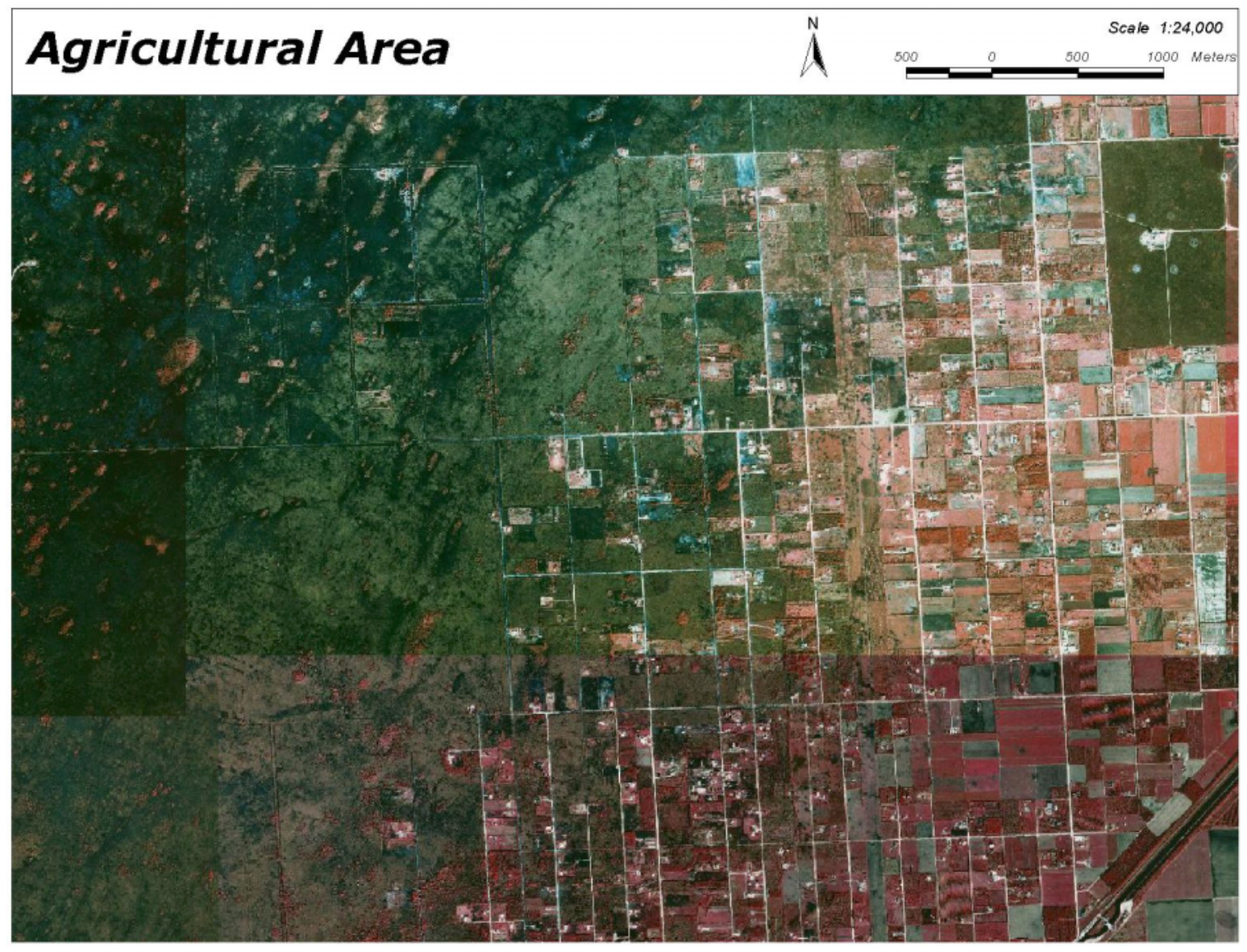

Figure 42. The eastern portion of this aerial photograph shows many areas that would have very small tract sizes and little habitat connectivity

Interior Core Area $\left(V_{C O R E}\right)$. This variable represents the interior portion of a wetland tract with at least a 300-m (990-ft) buffer separating it from adjacent Everglades wetland habitat (Figure 44). Interior core area is dictated by both the size and shape of the wetland. Large wetland tracts often have large interior core areas, but not always. For example, a large wetland tract that is circular in shape will have a much larger interior core area than a linearly shaped wetland tract of the same size. In the context of the function, this variable represents the availability of interior core areas that are adversely affected by fragmentation. The percentage of the wetland tract inside a buffer zone $300 \mathrm{~m}$ wide is used to quantify this variable. Measure the variable using the following procedure:

(1) Determine the area of the wetland tract within a buffer of $300 \mathrm{~m}$ using current aerial photography, topographic maps, or NWI maps.

(2) Divide the area of the wetland within the buffer by the total size of the wetland tract and multiply by 100 . The result is the percentage of the wetland tract within the buffer zone. 




Figure 43. This portion of Shark River Slough in Everglades National Park would have very large tract size and 100 percent habitat connectivity

(3) Report the size of the area within a 300-m buffer as a percentage of the total tract area.

(4) Using Figure 45 for Rocky and Marl Flats or Figure 46 for Organic Flats Everglades wetlands, determine the subindex score for interior core area.

(5) Verify during field reconnaissance.

In the Everglades reference wetlands, the percentage of the wetland tract within a buffer of $300 \mathrm{~m}$ ranged from 0 to 95 percent (Appendix D). Based on the range of values from reference standard wetlands, a variable subindex of 1.0 is assigned when 49 percent or more of the wetland tract is inside a buffer of at least $300 \mathrm{~m}$ (Figure 45 or Figure 46). As the percentage of the wetland tract within a $300-\mathrm{m}$ buffer decreases, a linearly decreasing subindex is assigned down to 0 at zero percent of the wetland tract. This is based on the assumption that, as the interior core area decreases, the suitability of the wetland tract for species requiring isolation from predators that frequent edges also decreases. 


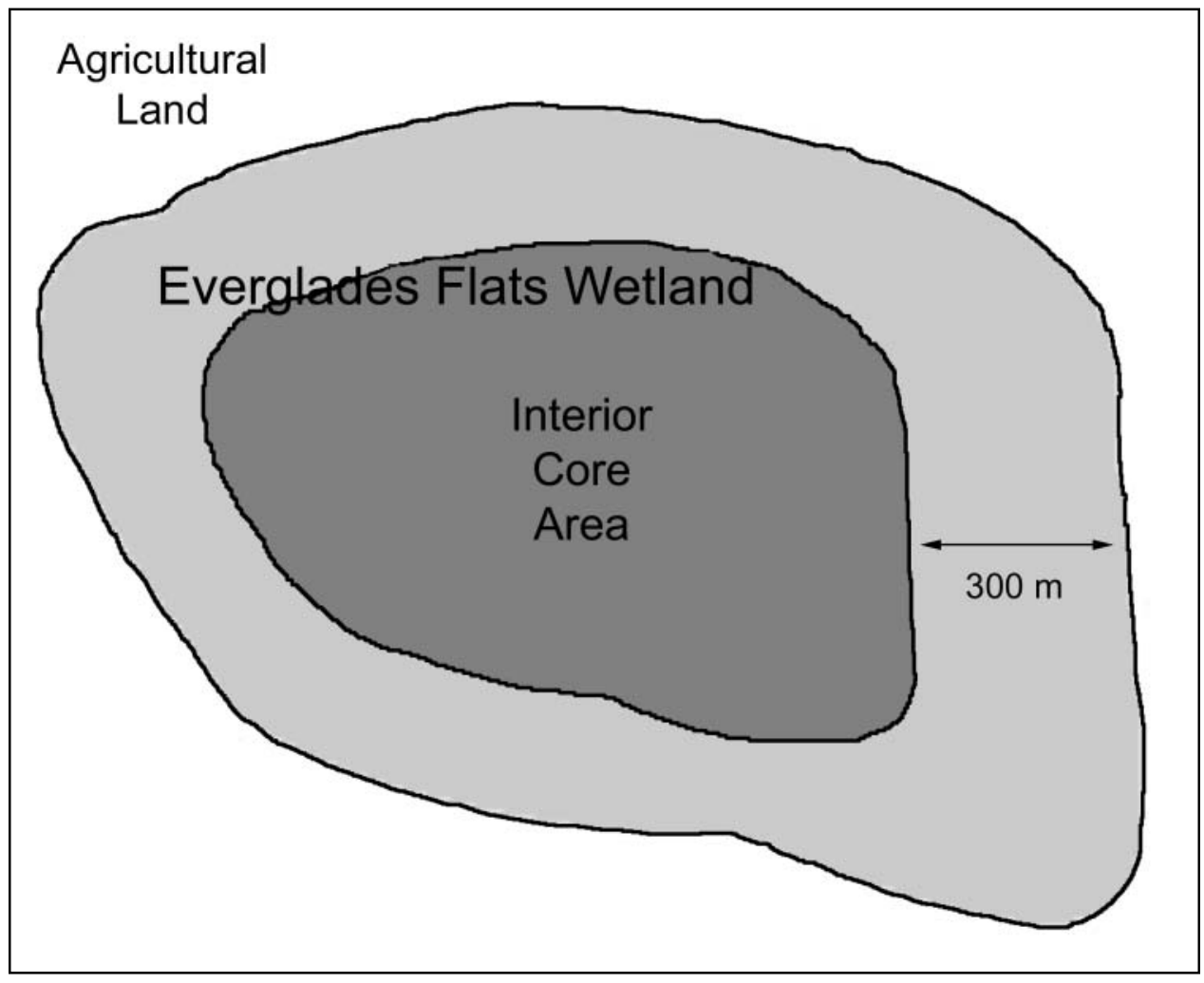

Figure 44. Interior core area and buffer zone

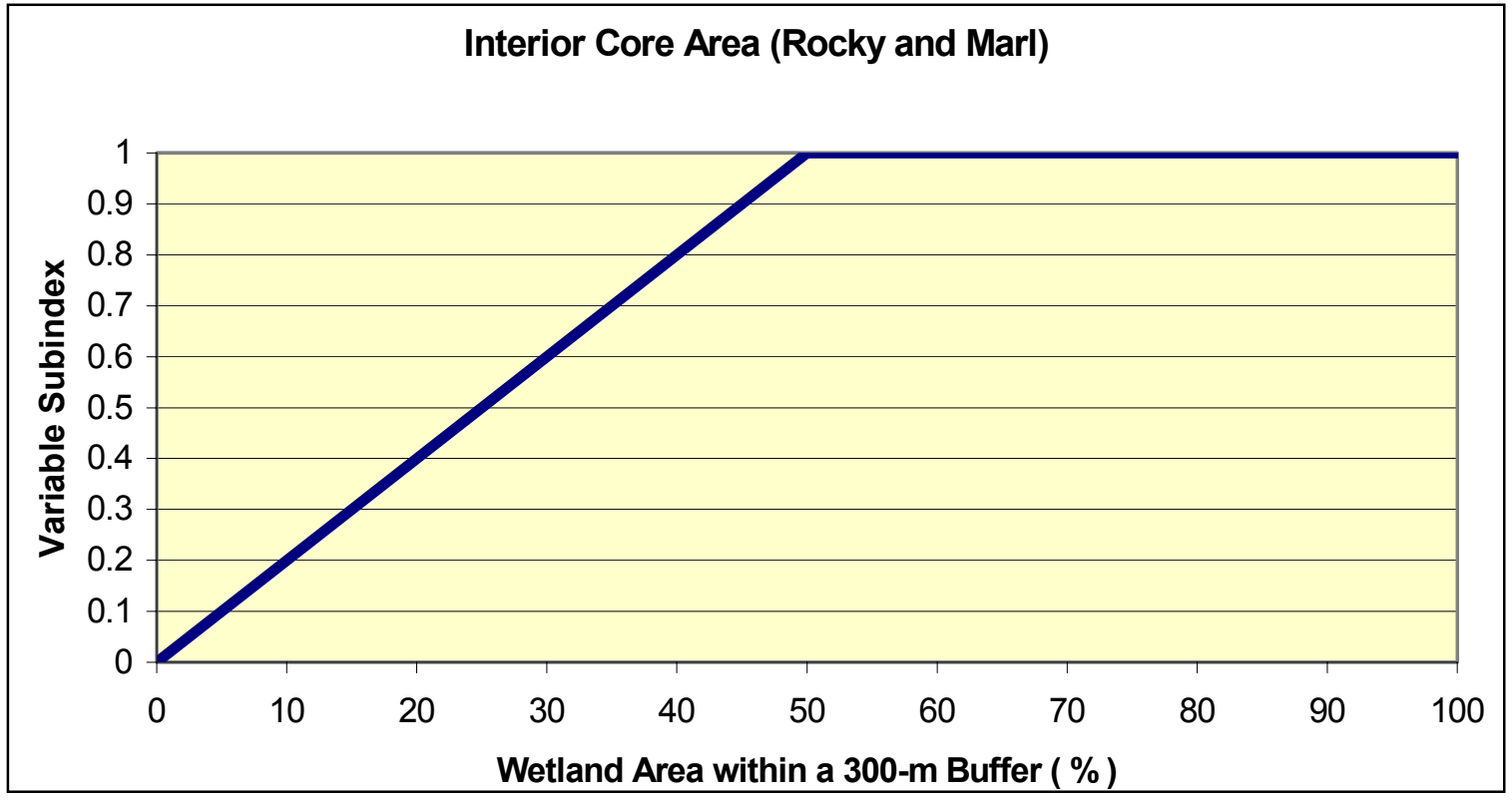

Figure 45. Interior core area for Rocky and Marl Flats Everglades wetlands and functional capacity 


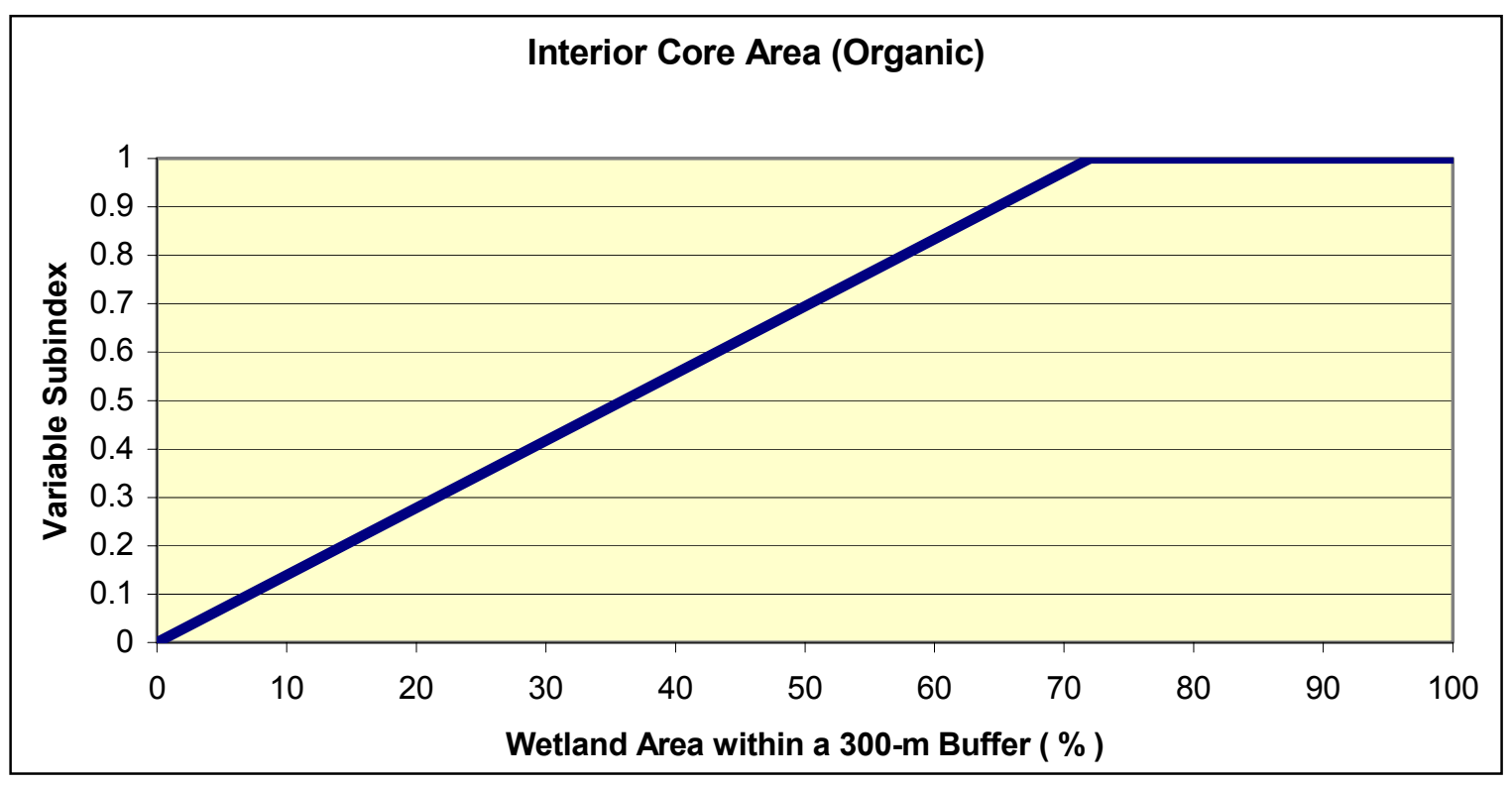

Figure 46. Interior core area for Organic Flats Everglades wetlands and functional capacity

Habitat Connections $\left(\boldsymbol{V}_{\text {ConNECT }}\right)$. This variable is defined as the percentage of the wetland that is connected to other types of wetlands, upland forests, or other suitable wildlife habitats (Figure 47). Agricultural fields, mined areas, or developed areas are not considered suitable habitat. An adjacent habitat is considered connected if it is within $0.5 \mathrm{~km}$ of the perimeter of the wetland. In the context of this function, this variable represents the need many species of wildlife have for other types of habitat to carry out their daily activities, such as feeding or resting, or to complete a particular phase of their life cycle and the importance of cover to move from one area to another. Birds and most of the large terrestrial vertebrates are capable of moving substantial distances (i.e. several kilometers) to disjunct patches. Smaller organisms with poor dispersal ability are the focus of this variable. Migration distances for most anurans (frogs, toads, etc.) seldom exceed 1,500 $\mathrm{m}$ and most species of salamanders move $<500 \mathrm{~m}$ (Sinsch 1990). The most restrictive distance, $0.5 \mathrm{~km}$, was chosen as the threshold between connected and disconnected habitats.

The percentage of the perimeter of the wetland tract that is directly adjacent to or "connected" is used to quantify this variable. Measure this variable using the following procedure:

(1) Determine the total length of the wetland tract perimeter using recent aerial photography, topographic maps, or NWI maps.

(2) Determine the length of the wetland that is "connected" to suitable habitats such as other types of wetlands, upland forest, or other wildlife habitats. 


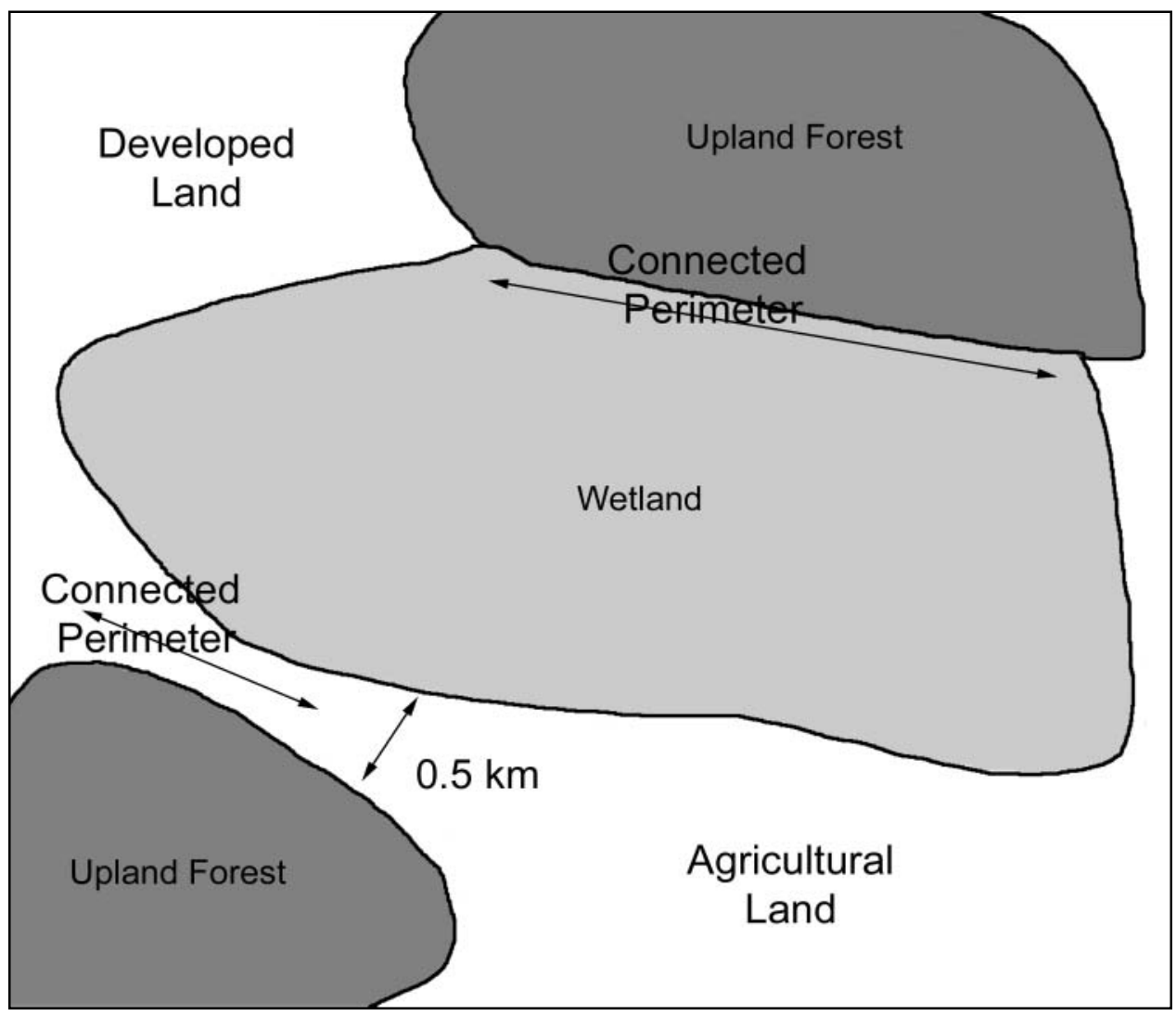

Figure 47. Adjacent habitats which are considered connected and not connected for determining $V_{\text {CONNECT }}$

(3) Divide the length of "connected" wetland perimeter by the total length of the wetland perimeter.

(4) Convert to a percentage of the perimeter by multiplying by 100 .

(5) Report the percentage of the perimeter of the wetland tract that is connected.

(6) Using Figure 48, determine the subindex score for habitat connections.

(7) Verify during field reconnaissance.

In Everglades reference wetlands, the ratio of connection to total perimeter length ranged from 0 to 100 percent. Based on data from reference standard sites, a variable subindex of 1.0 is assigned when 75 percent or more of the wetland tract perimeter is connected (Figure 48). As the percentage of wetland tract perimeter decreases, a linearly decreasing subindex is assigned down to 0 at zero percent connected wetland perimeter. This is based on the assumption that, as connections to other suitable habitats decrease, so does the suitability of the wetland tract as habitat for wide-ranging species or for those that require other habitats for a portion of their life cycle. 


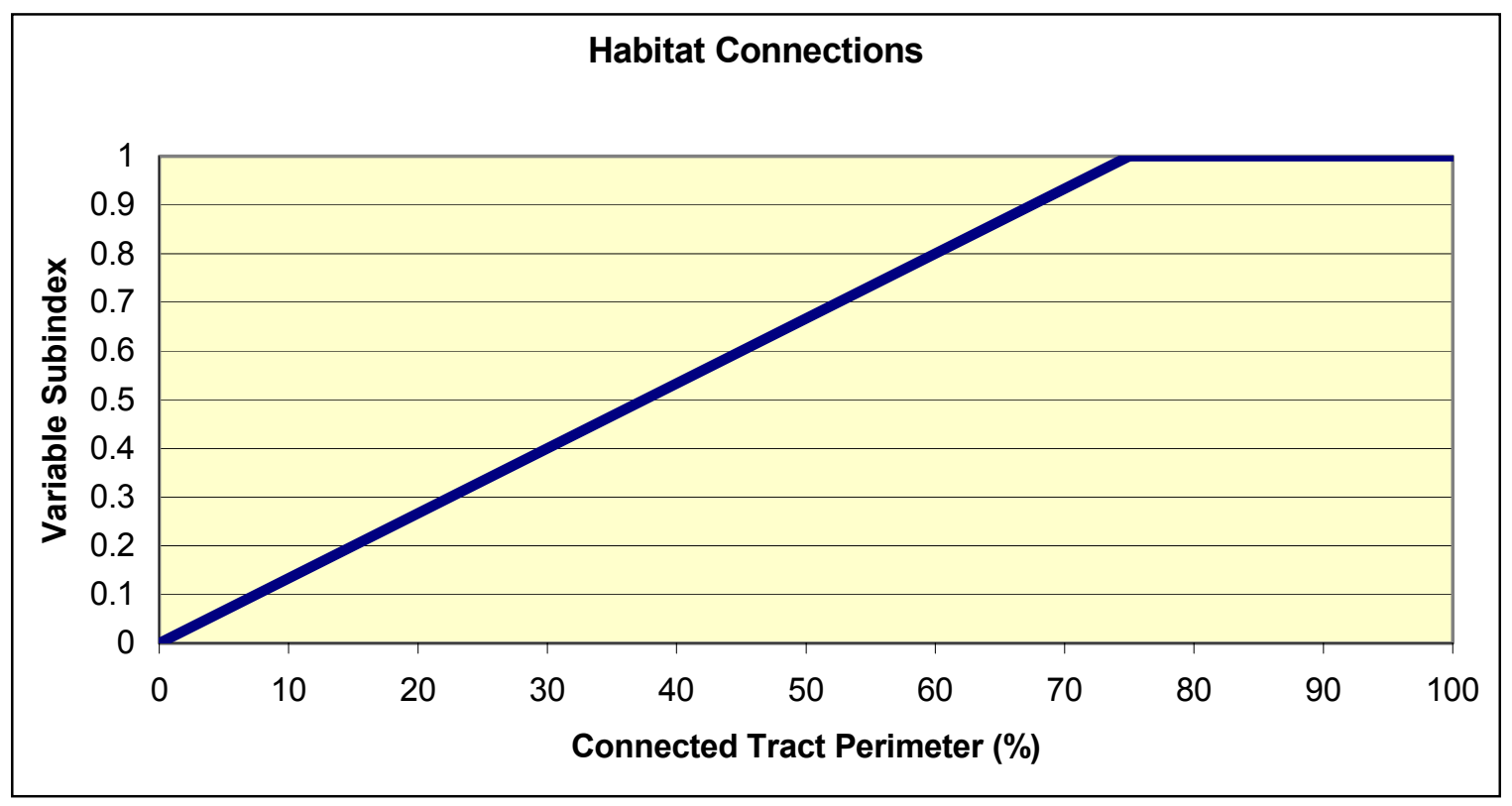

Figure 48. Relationship between perimeter tract connections and functional capacity

Surface Soil Texture $\left(V_{\text {SURTEX }}\right)$. This variable is defined as the USDA soil texture of the surface horizon or layer of the soil. Soil is the medium on which and in which water is stored. Altering the texture of the soil through anthropogenic activities (e.g., fill, excavation, rock plowing) changes the capacity of water storage. This variable is determined with the following procedure:

(1) Estimate the texture class of the surface horizon using the feel method in or adjacent to each of the three $1-\mathrm{m}^{2}\left(3.3-\mathrm{ft}^{2}\right)$ sampling units, hereafter called subplots, placed in representative portions of each quadrant of a 0.04-ha plot per WAA or PWAA. The number of 0.04-ha plots required to adequately characterize an area will depend on the size and heterogeneity of the site. Chapter 5, "Assessment Protocol," provides guidance for determining the number and layout of sample points and sampling units. Appendix $\mathrm{C}$ describes the procedure for estimating texture by class using the feel method.

(2) Using Table 23 for Rocky and Marl Flats or Table 24 for Organic Flats Everglades wetlands, assign a score for each texture class found.

(3) Determine the subindex by averaging the scores from each of the subplots.

Soil texture in the Everglades ranged from marl or muck to gravel. Based on reference standard sites, textures were marl for Rocky and Marl Flats sites and muck for Organic Flats sites. Other USDA textural classes received categorically lower subindex scores down to zero for gravel, bedrock, and pavement. 


\begin{tabular}{|c|c|}
\hline \multicolumn{2}{|c|}{$\begin{array}{l}\text { Table } 23 \\
\text { Soil Surface Texture for Rocky and Marl Flats Everglades Wetlands }\end{array}$} \\
\hline Soil Texture & Score \\
\hline Marl $^{1}$ & 1.0 \\
\hline Muck $^{1}$ & 0.8 \\
\hline Silt & 0.9 \\
\hline Silt loam & 0.9 \\
\hline Loam & 0.5 \\
\hline Gravelly silt loam (15\% to < 35\% gravel) & 0.4 \\
\hline Gravelly silt $(15 \%$ to $<35 \%$ gravel) & 0.4 \\
\hline Very gravelly silt loam (35\% to < $60 \%$ gravel) & 0.3 \\
\hline Very gravelly silt ( $35 \%$ to $<60 \%$ gravel) & 0.3 \\
\hline Sandy loam & 0.2 \\
\hline Clay & 0.2 \\
\hline Sand & 0.2 \\
\hline Loamy sand & 0.2 \\
\hline Extremely gravelly silt loam $(60 \%$ to $<90 \%$ gravel $)$ & 0.2 \\
\hline Extremely gravelly silt $(60 \%$ to $<90 \%$ gravel) & 0.2 \\
\hline Gravel $^{1}(\geq 90 \%$ gravel) & 0.1 \\
\hline Rock & 0.0 \\
\hline Pavement $^{1}$ & 0.0 \\
\hline
\end{tabular}

\begin{tabular}{|c|c|}
\hline \multicolumn{2}{|c|}{$\begin{array}{l}\text { Table } 24 \\
\text { Soil Surface Texture for Organic Flats Everglades Wetlands }\end{array}$} \\
\hline Soil Texture & Score \\
\hline Muck $^{7}$ & 1.0 \\
\hline Marl $^{1}$ & 0.8 \\
\hline Silt & 0.9 \\
\hline Silt loam & 0.9 \\
\hline Loam & 0.5 \\
\hline Gravelly silt loam ( $15 \%$ to $<35 \%$ gravel) & 0.4 \\
\hline Gravelly silt $(15 \%$ to $<35 \%$ gravel) & 0.4 \\
\hline Very gravelly silt loam ( $35 \%$ to $<60 \%$ gravel) & 0.3 \\
\hline Very gravelly silt (35\% to $<60 \%$ gravel) & 0.3 \\
\hline Sandy loam & 0.2 \\
\hline Clay & 0.2 \\
\hline Sand & 0.2 \\
\hline Loamy sand & 0.2 \\
\hline Extremely gravelly silt loam ( $60 \%$ to $<90 \%$ gravel) & 0.2 \\
\hline Extremely gravelly silt $(60 \%$ to $<90 \%$ gravel) & 0.2 \\
\hline Gravel $^{1}(\geq 90 \%$ gravel) & 0.1 \\
\hline Rock & 0.0 \\
\hline Pavement $^{1}$ & 0.0 \\
\hline
\end{tabular}

Soil Thickness ( $\left.V_{\text {Sогттнгк }}\right)$. This variable represents the total thickness of the soil over limestone rock in the Rocky Flats Everglades wetlands. This variable is defined as the average soil thickness within multiple plots, exclusive of solution holes. The depth or thickness of soil in the Rocky Flats Everglades is shallow to very shallow. An increase in the average soil thickness indicates disturbances such as the addition of fill material or rock plowing. These impacts affect the natural water-holding capacity of the soil. 
Thickness of the soil is used to quantify this variable. Measure it using the following procedure:

(1) Measure the total marl soil depth to limestone outside of solution holes in each of three $1-\mathrm{m}^{2}\left(3.3-\mathrm{ft}^{2}\right)$ subplots.

(2) Average the thickness from all of the subplots.

(3) Report soil thickness in centimeters.

(4) Using Figure 49, determine the subindex score for soil thickness in Rocky Everglades wetlands.

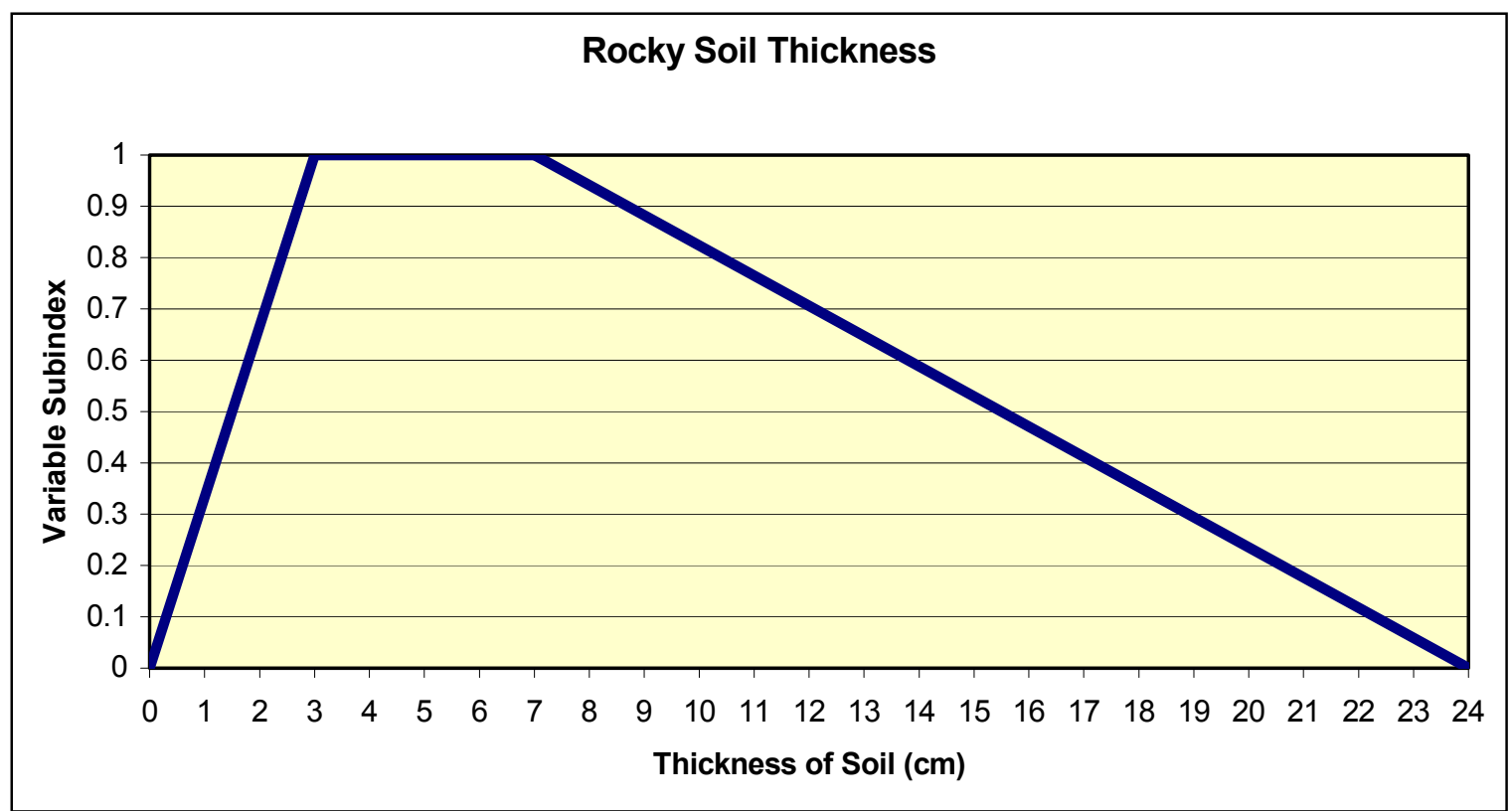

Figure 49. Relationship between soil thickness and functional capacity

In the Everglades wetlands this variable is applicable only to the Rocky Flats subclass. In the Everglades reference wetlands, soil thickness ranged from 0 to $32 \mathrm{~cm}$ for Rocky Flats wetlands. Based on data from reference standard wetlands sites, a variable subindex of 1.0 is assigned to sites with soil thickness between 3 and $7 \mathrm{~cm}$ for Rocky Flats wetlands. As soil thickness decreases below $3 \mathrm{~cm}$ or increases above $7 \mathrm{~cm}$ for Rocky Flats wetlands, a linearly decreasing subindex score down to zero is assigned for Rocky Flats sites at $0 \mathrm{~cm}$ and $24 \mathrm{~cm}$ total soil thickness. This is based on the assumption that the soil thickness is related to excavation or filling activities to the point that the site is no longer inundated or saturated under normal conditions. These assumptions could be validated using the independent, quantitative measures of function defined in the previous paragraph. 
Microtopographic Features $\left(V_{\text {MICRo }}\right)$. This variable represents the occurrence of microtopographic features in the Everglades wetland ecosystem. Microtopographic features are defined as small topographic changes in elevation, often less than $1 \mathrm{~cm}$, over short distances, usually less than $1 \mathrm{~m}$. Altering the microtopographic features of the landscape through anthropogenic activities (e.g., fill, excavation, rock plowing, land leveling, bedding) changes the water storage capability of the soil. This variable is determined with the following procedure:

(1) Determine if any of the WAA or PWAA has been altered by bedding, rock plowing, land leveling, or other activity that has altered the microtopographic features.

(2) If no altered areas exist, assign a value of 1.0. This indicates that the microtopography in the assessment area is similar to reference standard sites.

(3) If areas with altered microtopographic exist, determine what percent of the area has altered microtopography. Using Table 25, assign a subindex score for each alteration found.

(4) Report the percent of the WAA or PWAA with altered microtopography.

(5) Determine the subindex score for altered microtopography.

\begin{tabular}{||l|l||}
\hline \hline \multicolumn{2}{|l||}{$\begin{array}{l}\text { Table } \mathbf{2 5} \\
\text { Microtopographic Features }\end{array}$} \\
\hline \hline Alteration Category & Variable Subindex \\
\hline \hline Rock plowing & 0.0 \\
\hline Land leveling & 0.1 \\
\hline Bedding & 0.2 \\
\hline Unaltered & 1.0 \\
\hline
\end{tabular}

Microtopographic features in the Everglades were either 0 or 100 percent. The most significant topographic change in the Rocky Flats subclass is rock plowing. This mechanical scarifying of the landscape to create a soil deep enough to plant crops drastically alters the microtopographic features of this subclass to the point that restoration of this variable is impossible. In the Marl Flats subclass land leveling and bedding are the most significant impact on microtopographic features (Figure 50). However, the effects are completely opposite. Land leveling is the alteration of the landscape to remove the microtopographic features to improve surface drainage. Bedding is the practice of mounding the soil in rows to raise the root zone above the water table. This practice is usually used for ornamental nursery stock or fruit trees in the Marl Flats subclass. Unlike rock plowing, the site microtopographic features could be returned to some resemblance of predisturbance condition for areas that have been land-leveled or bedded. The Organic Flats subclass is most impacted by land leveling from the standpoint of microtopographic features. Restoration potential would be similar to Marl Flats sites for this variable. 


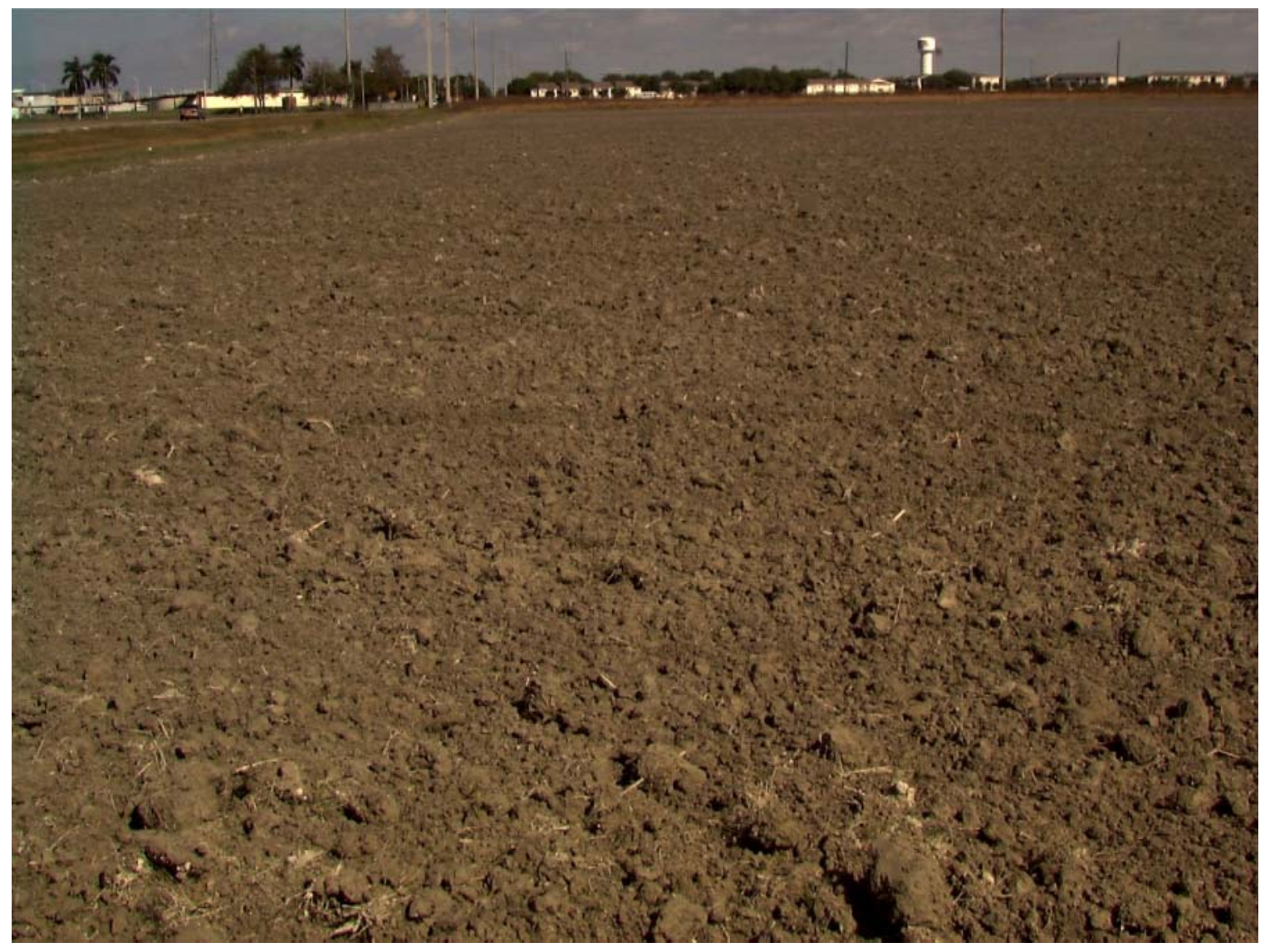

Figure 50. Microtopography altered by land leveling in the Marl Flats subclass

Emergent Macrophytic Vegetation Cover $\left(V_{M A C}\right)$. This variable represents the total cover of macrophytic vegetation in the wetland. It is defined as the average percent cover of emergent macrophytic vegetation $<1 \mathrm{~m}(3.3 \mathrm{ft})$ in height within multiple plots, exclusive of submerged aquatic vegetation and periphyton.

Percent cover of emergent macrophytic vegetation is used to quantify this variable. Measure it using the following procedure:

(1) Visually estimate the percentage of the ground surface that is covered by emergent macrophytic vegetation by mentally projecting the leaves and stems of to the ground surface in each of three $1-\mathrm{m}^{2}\left(3.3-\mathrm{ft}^{2}\right)$ subplots.

(2) Average the percent cover from all of the subplots.

(3) Report emergent macrophytic vegetation cover as a percent between 0 and 100 .

(4) Using Figure 51 for Rocky, Figure 52 for Marl, or Figure 53 for Organic Flats Everglades wetlands, determine the subindex score for percent cover of macrophytic vegetation. 


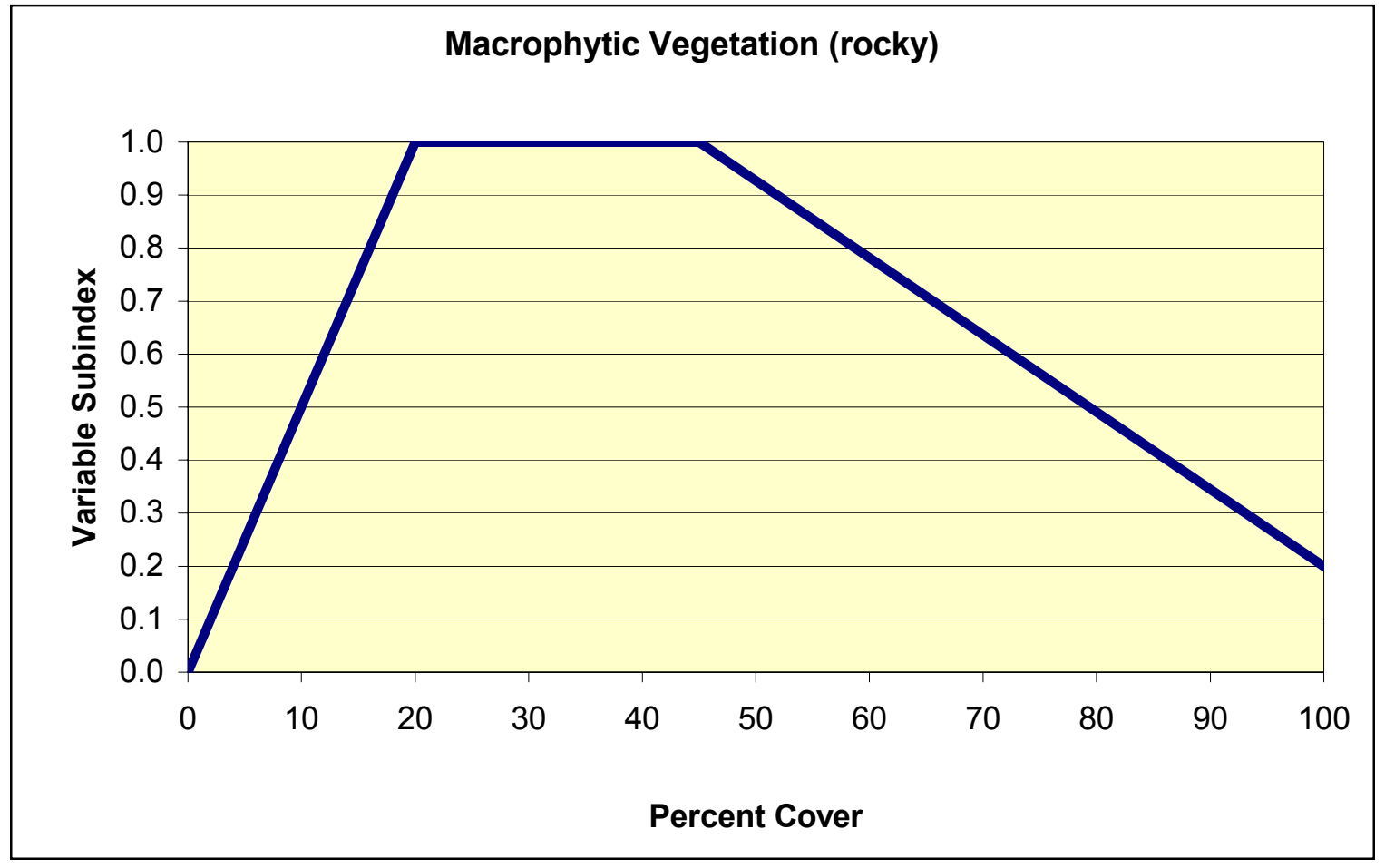

Figure 51. Relationship between macrophytic vegetation and functional capacity for Rocky Flats Everglades wetlands

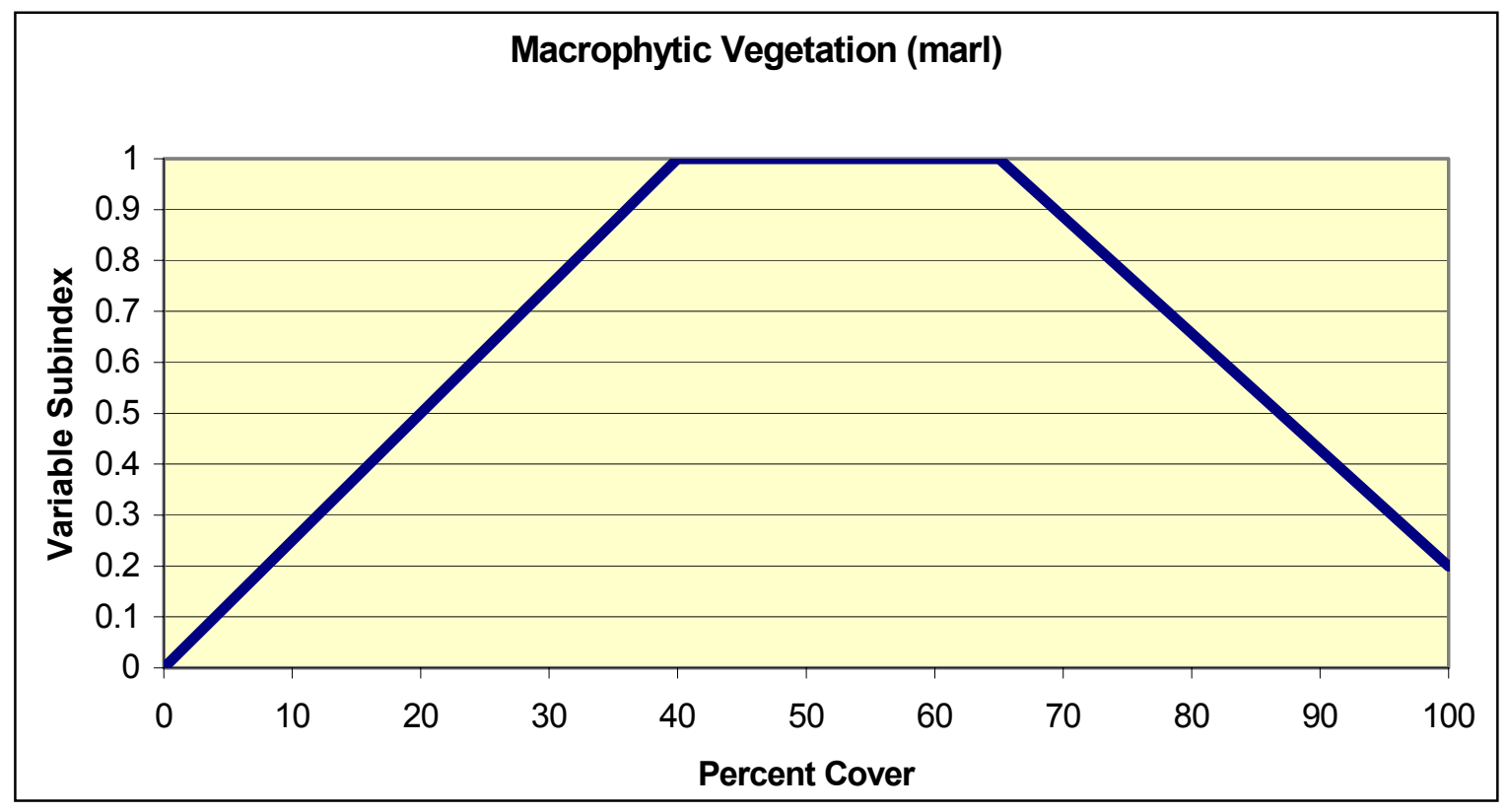

Figure 52. Relationship between macrophytic vegetation and functional capacity for Marl Flats Everglades wetlands 


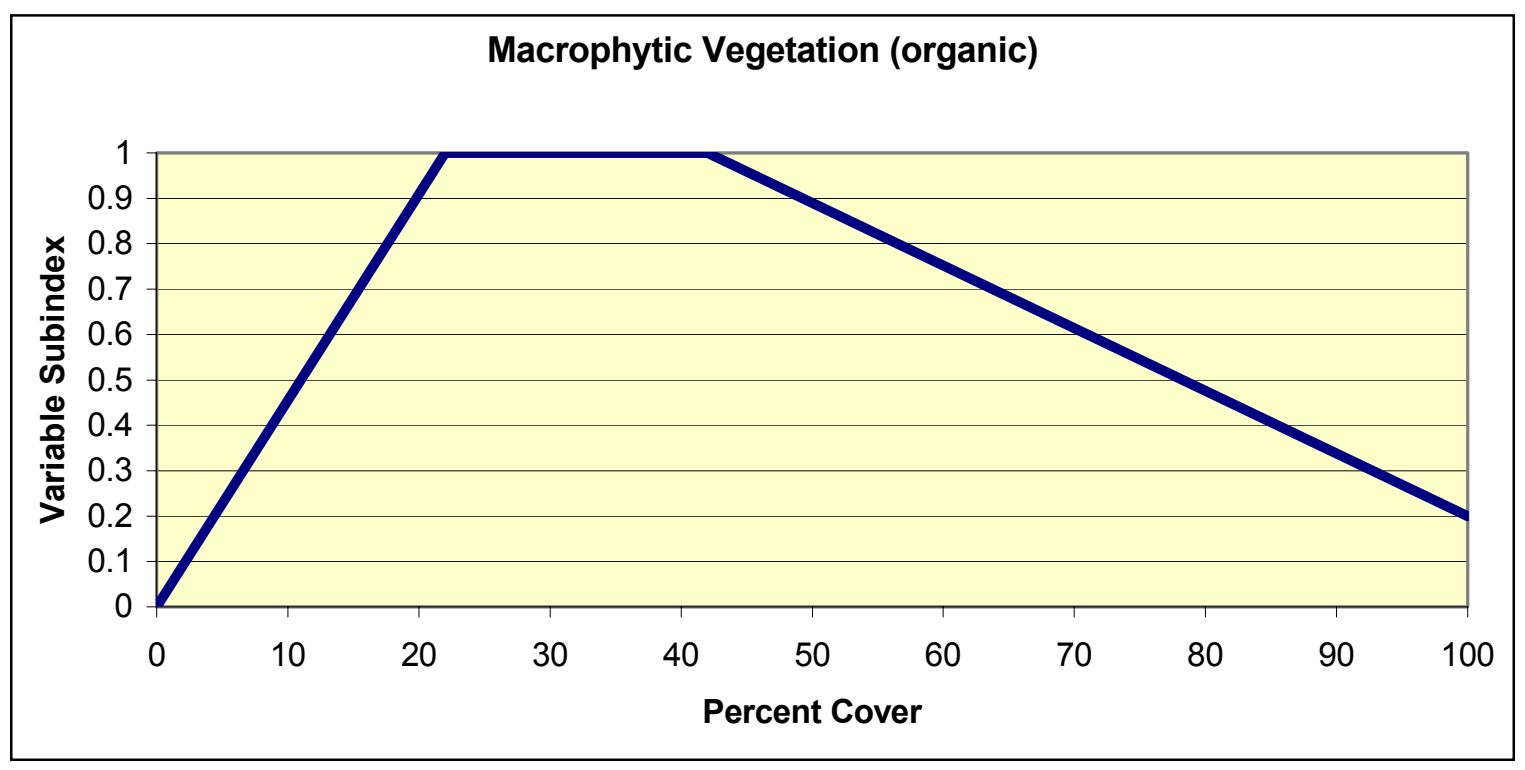

Figure 53. Relationship between macrophytic vegetation and functional capacity for Organic Flats Everglades wetlands

In the Everglades reference wetlands, emergent macrophytic vegetation cover ranged from 2 to 90 percent for Rocky Flats wetlands, 12 to 98 percent for Marl Flats wetlands, and 3 to 98 percent for Organic Flats wetlands. Based on data from reference standard wetlands sites, a variable subindex of 1.0 is assigned to sites with emergent macrophytic vegetative cover between 20 and 45 percent for Rocky Flats wetlands, between 40 and 65 percent for Marl Flats wetlands, and between 22 and 42 percent for Organic Flats wetlands. Zero percent cover of macrophytic vegetation, while not measured, would indicate severely altered conditions. As percent cover of emergent macrophytic vegetation increases above 45 percent for Rocky Flats sites, 65 percent for Marl Flats sites, and 42 percent for Organic Flats sites, a linearly decreasing subindex score down to 0.2 is assigned for Rocky, Marl, and Organic Flats sites at 100 percent cover of emergent macrophytic vegetation. This is based on the assumption that the increase in emergent macrophytic vegetation cover indicates unnatural levels of productivity such as following fertilization. The rate at which the subindex decreases and the selection of 0.2 as variable subindex end points at 100 percent cover are based on the assumption that the relationship between percent cover of emergent macrophytic vegetation and nutrient cycling is linear and that emergent macrophytic vegetation is contributing to nutrient cycling even when percent cover is high. These assumptions could be validated using the independent, quantitative measures of function defined in the previous paragraph.

Periphyton Cover $\left(\boldsymbol{V}_{\text {PERI }}\right)$. This variable, which represents the total cover of periphyton in the wetland, is defined as the average percent cover of periphyton within multiple plots.

Percent cover of periphyton is used to quantify this variable. Measure it using the following procedure: 
(1) Visually estimate the percentage of the ground surface that is covered by emergent periphyton in each of three $1-\mathrm{m}^{2}\left(3.3-\mathrm{ft}^{2}\right)$ subplots.

(2) Average the percent cover from all of the subplots.

(3) Report periphyton cover as a percent between 0 and 100.

(4) Using Figure 54 for Rocky Flats or Figure 55 for Marl Flats Everglades wetlands, determine the subindex score for the percent cover of periphyton.

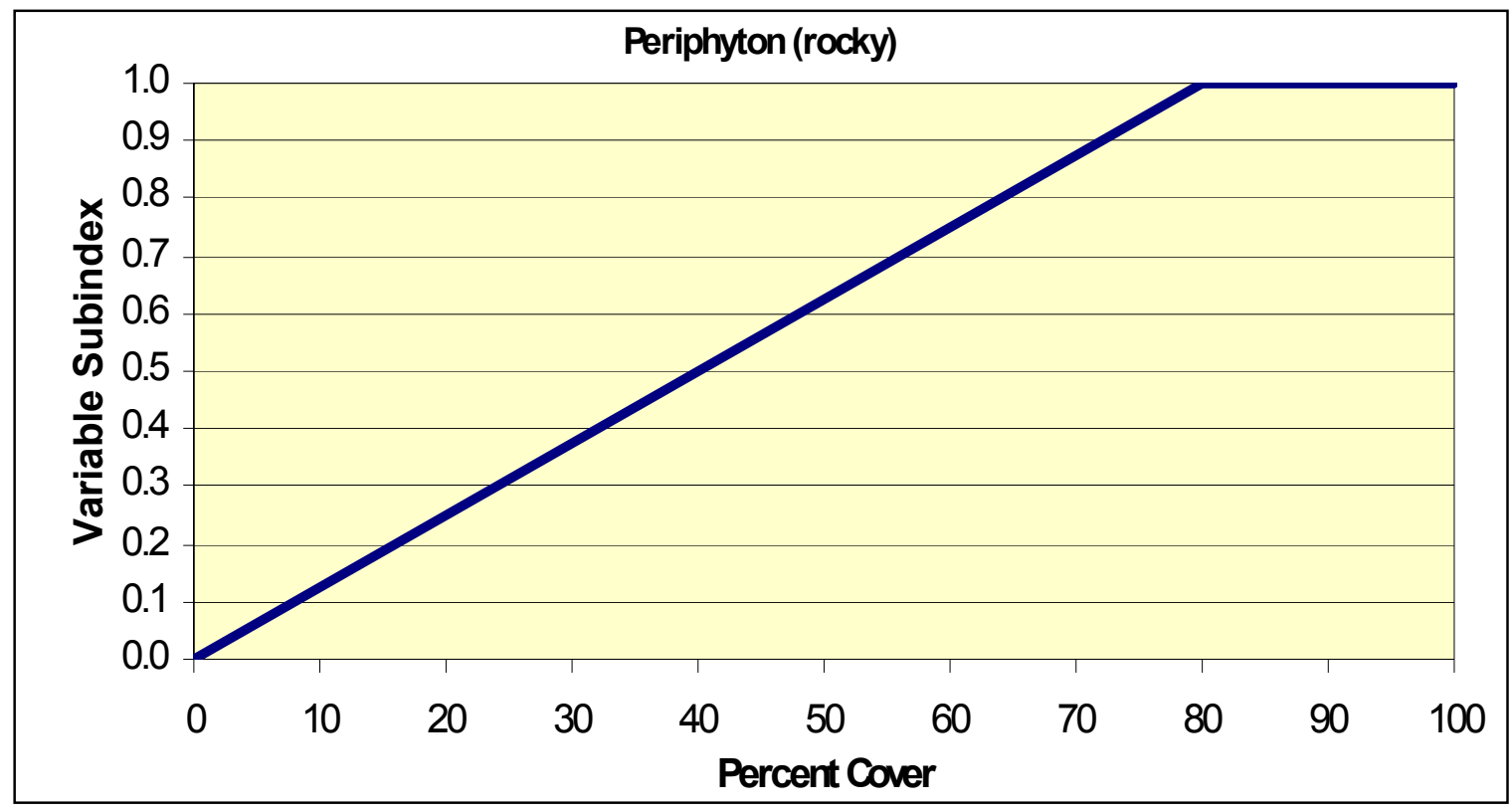

Figure 54. Relationship between periphyton and functional capacity for Rocky Flats Everglades wetlands

In the Everglades this variable is applicable only to the Rocky and Marl Flats Everglades subclasses. In the Everglades reference wetlands, periphyton cover ranged from 0 to 96 percent for both Rocky and Marl Flats wetlands (Figure 56). Based on data from reference standard wetlands sites, a variable subindex of 1.0 is assigned to sites with periphyton cover between 80 and 100 percent for Rocky Flats wetlands and between 50 and 100 percent for Marl Flats wetlands. Zero percent cover of periphyton indicates severely altered conditions. As percent cover of periphyton decreases below 80 percent for Rocky Flats sites and 50 percent for Marl Flats sites, a linearly decreasing subindex score down to zero is assigned for Rocky and Marl Flats sites at 0 percent cover of periphyton. This is based on the assumption that the decrease in periphyton cover indicates altered hydrology and/or disturbance such as plowing. The rate at which the subindex decreases and the selection of zero as variable subindex end point at 0 percent cover are based on the assumption that the relationship between percent cover of periphyton and altered hydrology is linear. These assumptions could be validated using the independent, quantitative measures of function defined in the previous paragraph. 


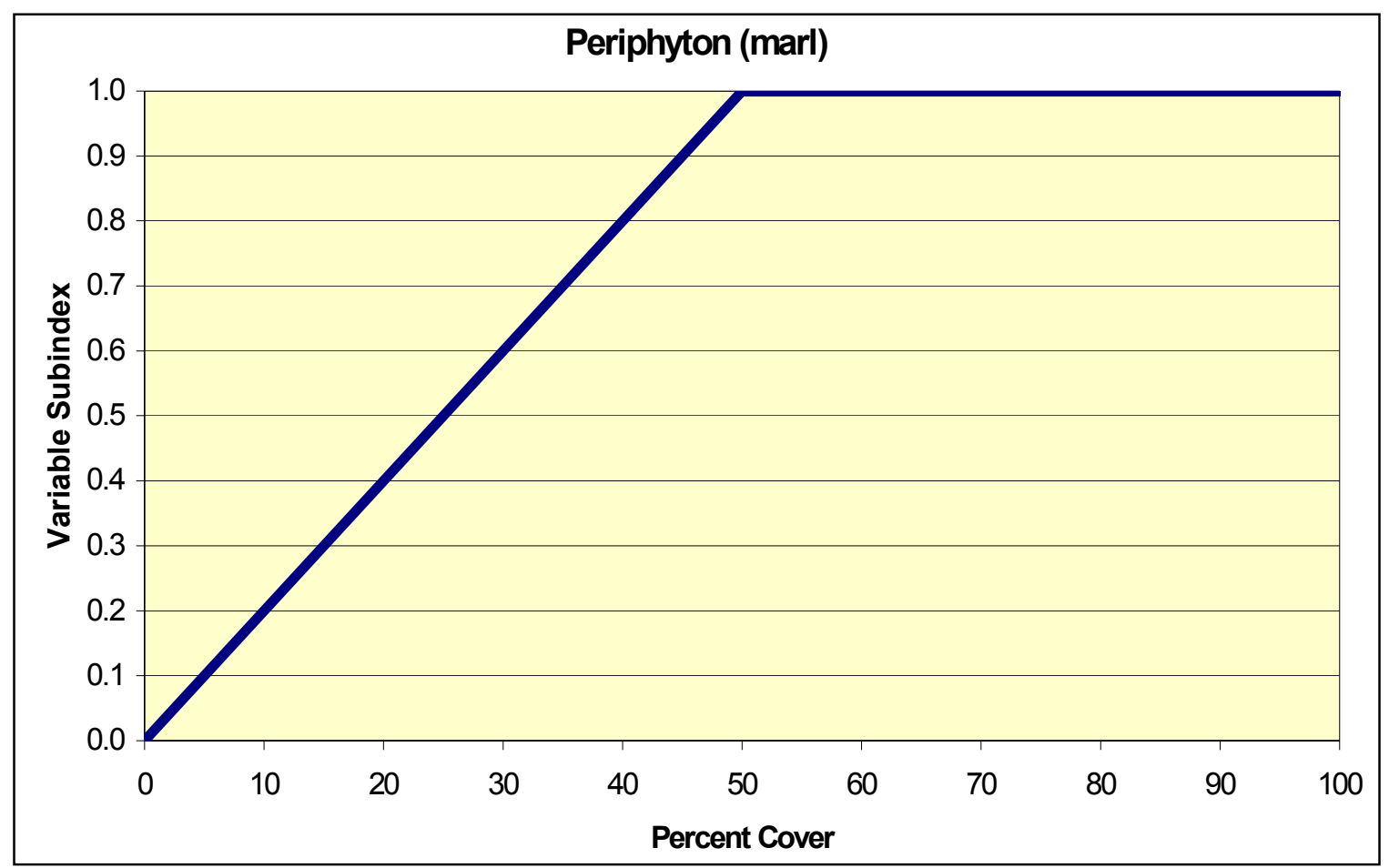

Figure 55. Relationship between periphyton and functional capacity for Marl Flats Everglades wetlands

Invasive Vegetation Cover ( $\left.\boldsymbol{V}_{\text {INVASIVE }}\right)$. This variable, which represents the total cover of invasive vegetation in the wetland, is defined as the average percent cover of invasive vegetation in all strata within multiple plots. For this Guidebook, invasive species are those species identified by the Florida Exotic Pest Plants Council (Table 16).

Percent cover of invasive vegetation is used to quantify this variable. Measure it using the following procedure:

(1) Visually estimate the percentage of the ground surface that is covered by invasive vegetation by mentally projecting the leaves and stems to the ground surface in each 11.3-m- (37.2-ft-) radius plot, placed in representative portions of each WAA or PWAA. The number of plots required to adequately characterize an area will depend on the size and heterogeneity of the site. Chapter 5, "Assessment Protocol," provides guidance for determining the number and layout of sample points and sampling units.

(2) Average the percent cover from all of the plots.

(3) Report invasive vegetation cover as a percent.

(4) Using Figure 57, determine the subindex score for percent cover of invasive vegetation. 


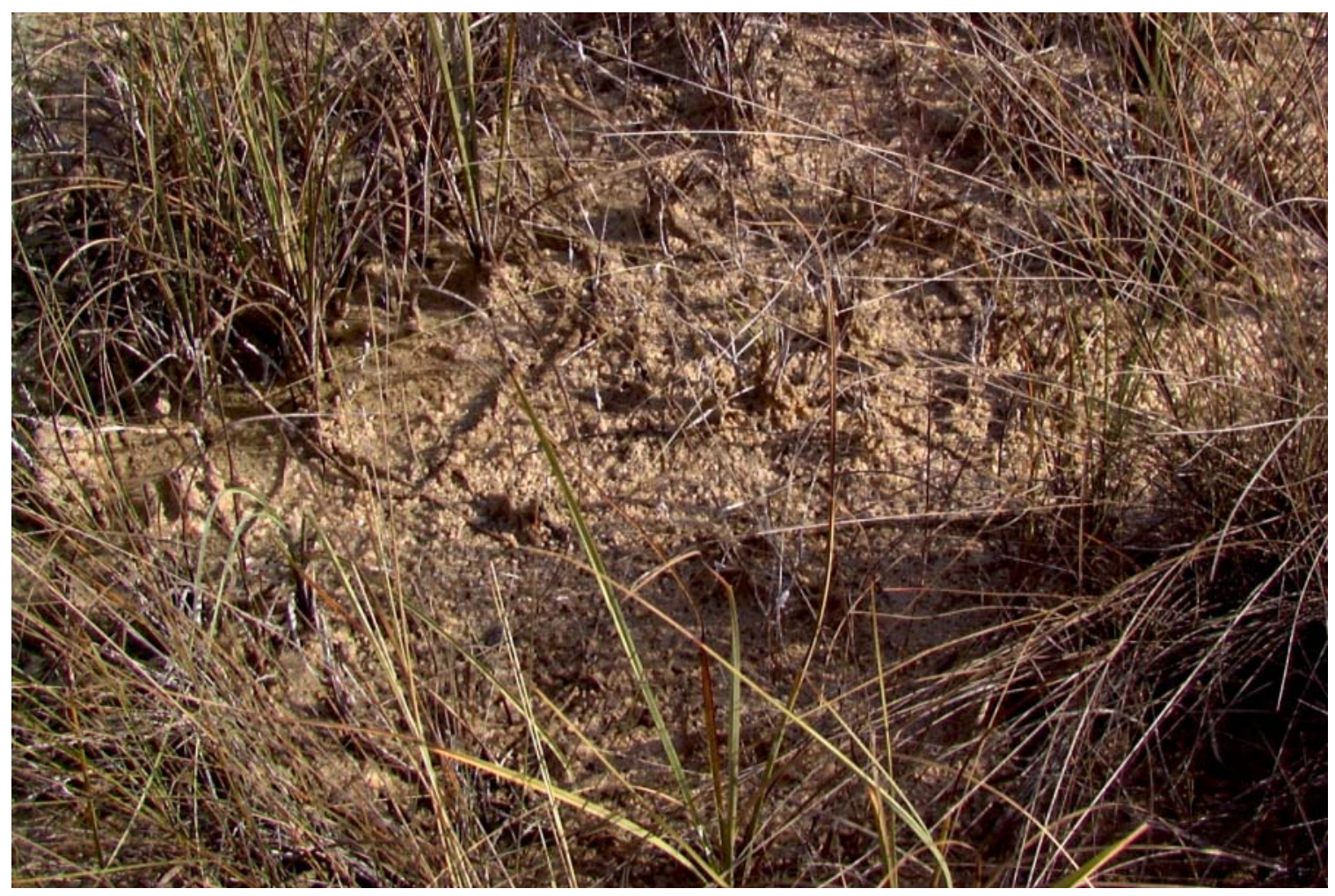

Figure 56. Periphyton on surface

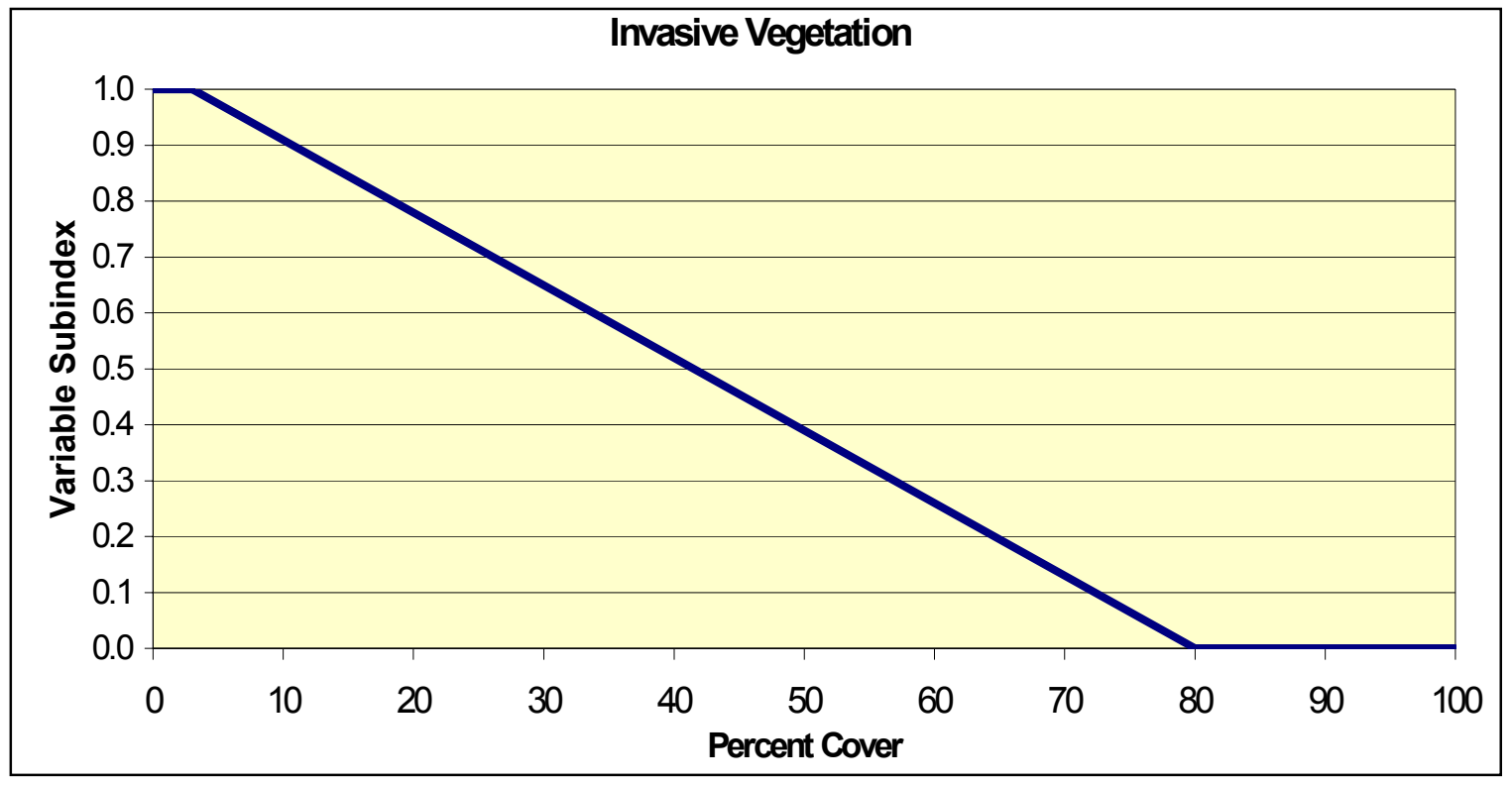

Figure 57. Relationship between percent cover of invasive vegetative cover and functional capacity 
In the Everglades reference wetlands, invasive vegetation cover ranged from 0 to 72 percent for the three subclasses sampled. Based on data from reference standard wetlands sites, a variable subindex of 1.0 is assigned to sites with invasive vegetative cover between 0 and 3 percent for Rocky, Marl, and Organic Flats wetlands (Figure 58). As percent cover of invasive vegetation increases above 3 percent, a linearly decreasing subindex score down to zero is assigned for wetlands at 80 to 100 percent cover of invasive vegetation. This is based on the assumption that the increase in invasive vegetation cover indicates unnatural levels of productivity, changes in hydroperiod, and increased evapotranspiration. The rate at which the subindex decreases and the selection of zero as variable subindex end point at 100 percent cover are based on the assumption that the relationship between percent cover of invasive vegetation and impacts is linear. These assumptions could be validated using the independent, quantitative measures of function defined in the previous paragraph.

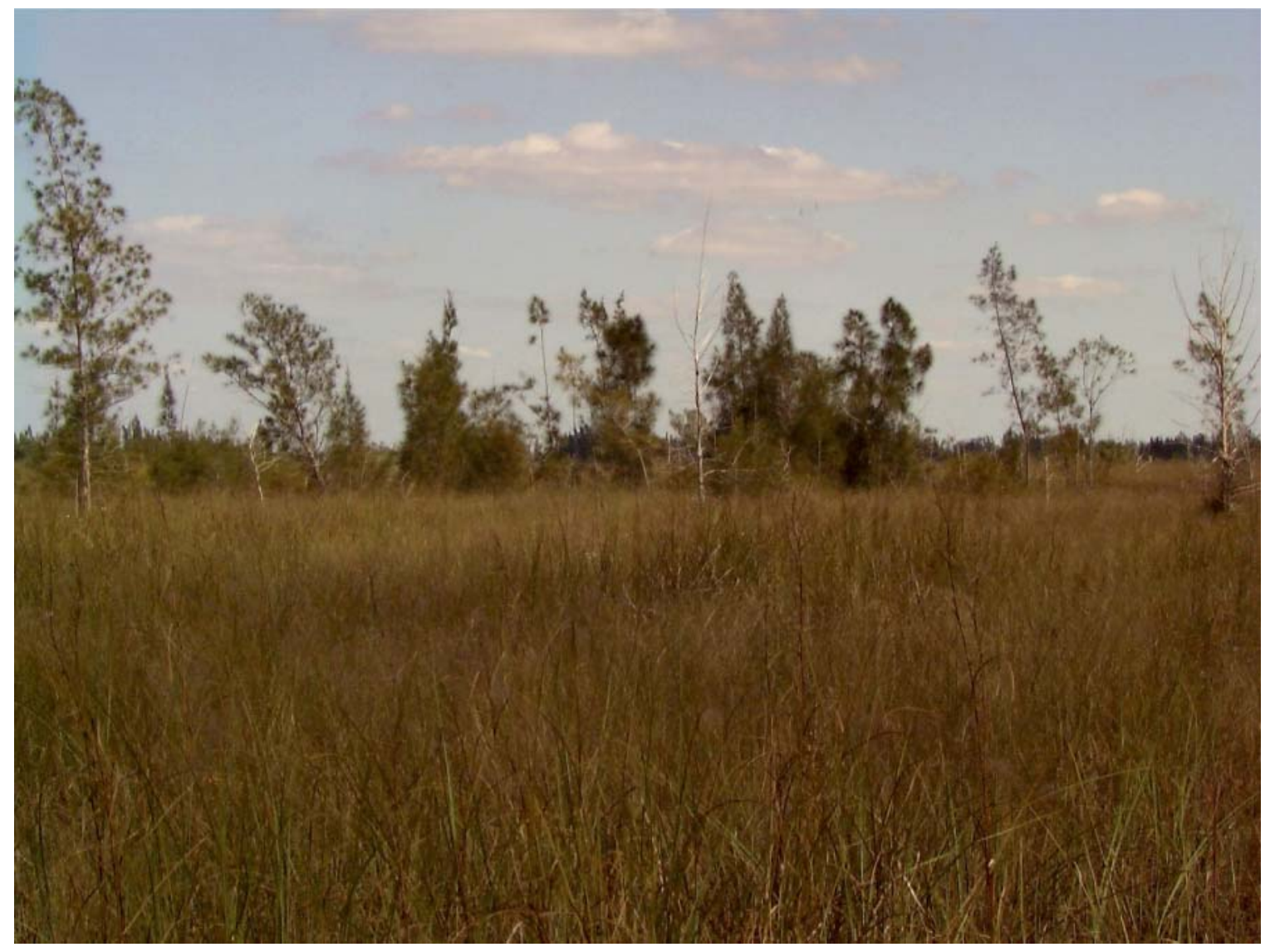

Figure 58. Casuarina equisetifolia (Australian pine) invading an area of Rocky Flats Everglades wetlands

Plant Species Composition $\left(V_{\text {СомP }}\right)$. Plant species composition represents the dominance of certain native wetland plants in proportion to sites representing those with the least disturbance in the Everglades. Ideally, plant species composition would be determined with intensive sampling of herbaceous species. 
Unfortunately, the time and taxonomic expertise required to accomplish this are not available in the context of rapid assessment. Thus, the focus here is on the dominant species in the herbaceous strata.

Percent concurrence with the dominant species in the herbaceous stratum is used to quantify this variable. Measure it with the following procedure:

(1) Identify the dominant species in the ground vegetation strata using the 50/20 rule. ${ }^{1}$ To apply the 50/20 rule, rank species from the herbaceous stratum in descending order of abundance. Identify dominants by summing the relative abundances beginning with the most abundant species in descending order until 50 percent is exceeded. Additional species with $\geq 20$ percent relative abundance should also be considered as dominants. If no species is equal to or greater than 20 percent, then identify the species with the greatest percent cover. Accurate species identification is critical for determining the dominant species in each plot.

Sampling during the dormant season or after a fire may require a high degree of proficiency. Users who do not feel confident in identifying herbaceous plant species should get help with plant identification.

(2) Calculate percent concurrence by comparing the list of dominant plant species to the list of dominant species in reference standard wetlands (Table 26 or Table 27). For example, if all the dominants from the area being assessed occur on the list of dominants from reference standard wetlands, then there is 100 percent concurrence. If three of the five dominant species from the area being assessed occur on the list, then there is a 60 percent concurrence.

(3) Report concurrence of species dominants as a percent.

\section{Table 26 \\ Dominant Plant Species, Marl Flats}

\begin{tabular}{||l|l|}
\hline \hline Scientific Name & Common Name \\
\hline \hline Andropogon glomeratus & Bushy bluestem \\
\hline Bacopa caroliniana & Blue waterhyssop \\
\hline Crinum americanun & Saw grass \\
\hline Eragrostis refracta & Seven sisters \\
\hline Hyptis alata & Coastal lovegrass \\
\hline Mikania scandens & Clustered bushmint \\
\hline Muhlenbergia capillaris & Climbing hempweed \\
\hline Panicum tenerum & Muhly grass \\
\hline Paspalum monastachyum & Bluejoint panic grass \\
\hline Pluchea rosea & Gulfdune paspalum \\
\hline Proserpinaca palustris & Rosy camphorweed \\
\hline Rhynchospora divergens & Marsh mermaid weed \\
\hline Rhynchospora microcarpa & Spreading beaksedge \\
\hline Rhynchospora tracyi & Southern beaksedge \\
\hline Schizachyrium rhizomatum & Tracy's beaksedge \\
\hline Spartina alterniflora & Florida little bluestem \\
\hline Utricularia purpurea & Smooth cordgrass \\
\hline
\end{tabular}

${ }^{1}$ Memorandum, 6 March 1992, Office, Chief of Engineers, Clarification of Use of the 1987 Delineation Manual. 


\begin{tabular}{||l|l||}
\hline \hline \multicolumn{2}{||l||}{ Table 27} \\
Dominant Plant Species, Organic Flats \\
\hline \hline Scientific Name & Common Name \\
\hline \hline Bacopa caroliniana & Blue waterhyssop \\
\hline Cladium jamaicense & Saw grass \\
\hline Eleocharis cellulosa & Coastal spikerush \\
\hline Eleocharis elongata & Slim spikerush \\
\hline Panicum hemitomon & Maiden cane \\
\hline Peltandra virginica & Green arrow arum \\
\hline Polygonum hydropiperoides & Swamp smartweed \\
\hline Pontederia cordata & Pickerelweed \\
\hline Sagittaria lanceolata & Bulltongue arrowhead \\
\hline Utricularia foliosa & Leafy bladderwort \\
\hline Utricularia purpurea & Eastern purple bladderwort \\
\hline \hline
\end{tabular}

In the Everglades reference wetlands, percent concurrence with dominant species ranged from 0 to 100 percent (Appendix D). Based on the data from reference standard sites a variable subindex of 1.0 is assigned when concurrence with dominant species is 100 percent for a wetland subclass (Figure 59). As percent concurrence decreases, a linearly decreasing subindex down to zero is assigned based on the assumption that the relationship between plant species composition and the capacity of Everglades wetlands to maintain a characteristic plant community is linear.

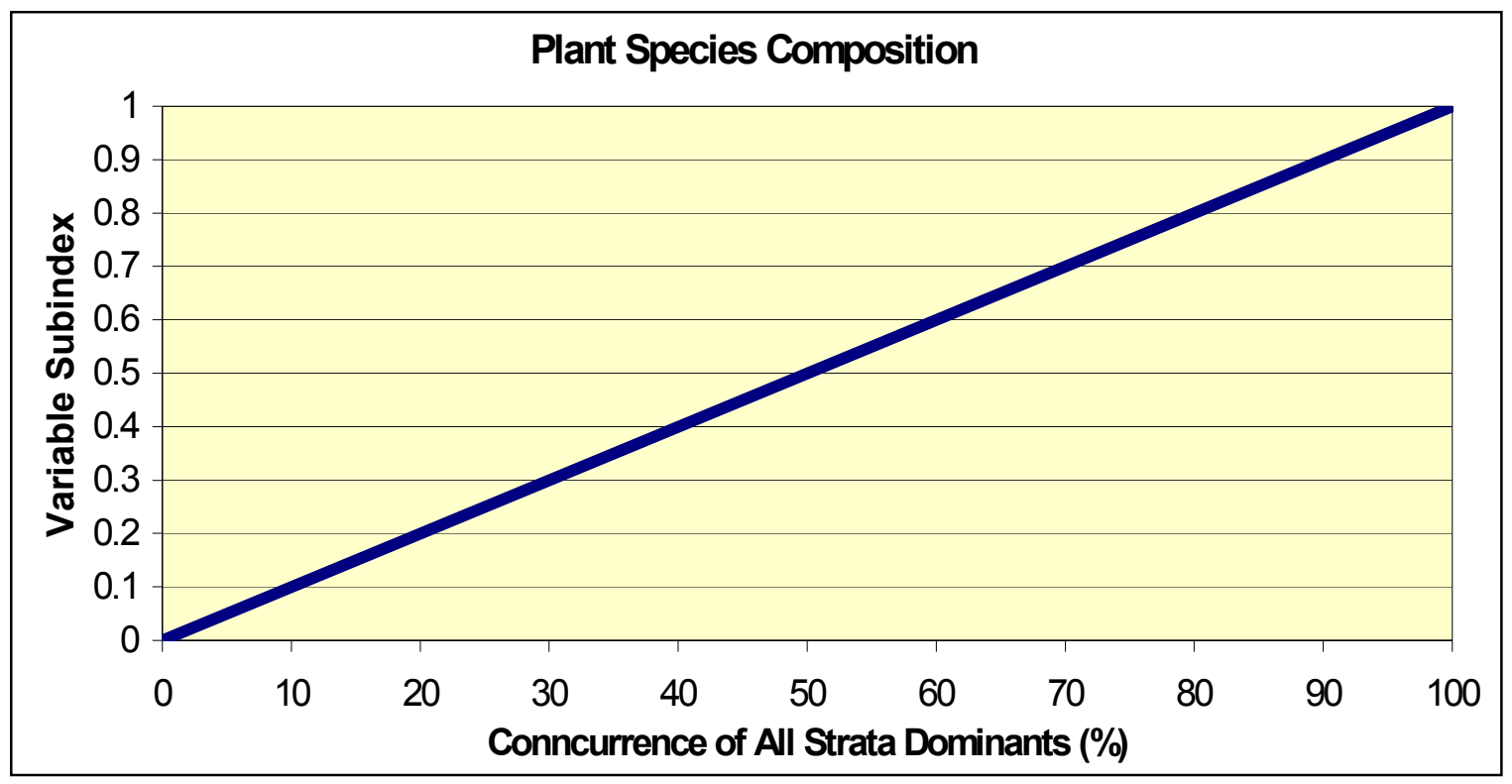

Figure 59. Relationship between percent concurrence of strata dominants and functional capacity

Number of Native Wetland Species $\left(\mathbf{V}_{\text {NATIVE }}\right)$. This variable represents the number of native wetland species that occur on a site in the Everglades ecosystem. In general, Rocky Flats Everglades wetlands support over 100 native wetland species (Lodge 1994). Disturbed sites usually have fewer native wetland species than undisturbed sites to the point that sites can become dominated by 
one or two species. Ideally, number of native wetland species would be determined with intensive sampling over the entire site. Unfortunately, the time required is not practical for a rapid assessment. This variable is determined using the following procedure:

(1) Count each native vegetative species that has a Wetland Indicator Status of FAC, FACW, or OBG in each strata. Add the number of native wetland species from each vegetative strata and report the total number of native wetland species. Users do not need to determine the taxonomic classification of each species, but must be able to recognize those species that are not native to Florida and are not typically found in wetlands. Users who do not feel confident in making these identifications should get help with plant identification.

(2) Using Table 28, assign a variable subindex score.

\begin{tabular}{|c|c|}
\hline \multicolumn{2}{|c|}{$\begin{array}{l}\text { Table } 28 \\
\text { Number of Native Wetland Species in Rocky Flats Everglades } \\
\text { Wetlands }\end{array}$} \\
\hline Number of Species & Subindex Score \\
\hline$\geq 20$ & 1.0 \\
\hline 19 & 0.95 \\
\hline 18 & 0.9 \\
\hline 17 & 0.85 \\
\hline 16 & 0.8 \\
\hline 15 & 0.75 \\
\hline 14 & 0.7 \\
\hline 13 & 0.65 \\
\hline 12 & 0.6 \\
\hline 11 & 0.55 \\
\hline 10 & 0.5 \\
\hline 9 & 0.45 \\
\hline 8 & 0.4 \\
\hline 7 & 0.35 \\
\hline 6 & 0.3 \\
\hline 5 & 0.25 \\
\hline 4 & 0.20 \\
\hline 3 & 0.1 .5 \\
\hline 2 & 0.1 \\
\hline 1 & 0.05 \\
\hline 0 & 0 \\
\hline
\end{tabular}

In the Rocky Flats Everglades reference wetlands the number of native wetland species ranged from 3 to 39 (Appendix D). Based on the data from reference standard sites, a variable subindex score would be assigned when the number of native wetland species is 15 or greater. As the number of species decreases, a linearly decreasing subindex down to zero is assigned based on the assumption that the relationship between the number of native wetland species and the capacity of Rocky Flats Everglades wetlands to maintain a diverse native wetland plant community is linear. 


\section{Functional capacity index}

The assessment model for calculating the functional capacity index is as follows:

a. For Rocky Flats Everglades wetlands:

$$
F C I=\left\{\begin{array}{l}
{\left[\frac{\left(\frac{V_{\text {CONNECT }}+V_{\text {CORE }}+V_{\text {TRACT }}}{3}\right)+\left(\frac{V_{\text {SURTEX }}+V_{\text {SOILTHICK }}+V_{\text {MICRO }}}{3}\right)}{2}\right]} \\
\times\left(\frac{V_{M A C}+V_{P E R I}+V_{\text {INVASIVE }}+V_{\text {NATIVE }}}{4}\right)
\end{array}\right\}^{1 / 2}
$$

b. For Marl Flats Everglades wetlands:

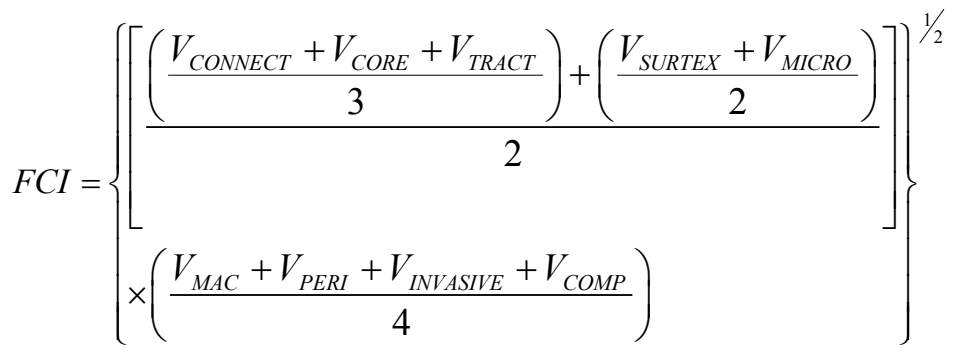

c. For Organic Flats Everglades wetlands:

$$
F C I=\left\{\begin{array}{l}
{\left[\frac{\left(\frac{V_{C O N N E C T}+V_{\text {CORE }}+V_{\text {TRACT }}}{3}\right)+\left(\frac{V_{\text {SURTEX }}+V_{\text {MICRO }}}{2}\right)}{2}\right]} \\
\times\left(\frac{\left.V_{\text {MAC }}+V_{\text {INVASIVE }}+V_{\text {COMP }}\right)}{3}\right)
\end{array}\right\}^{1 / 2}
$$

These models are assumed to reflect the habitat that is necessary to provide food, cover, and nesting opportunities for birds and other wildlife species native to the Everglades ecosystem. If all the components are similar to reference standard conditions (i.e., a large, diverse, unfragmented herbaceous system that is inundated yearly), there is a high probability that native wildlife species will use the site. The variables have been grouped by the three major components: landscape, soils, and biotic community. It should be noted that the emphasis is on onsite conditions. Even in largely fragmented landscapes if reference standard conditions exist onsite, the majority of wildlife species will use the site during certain seasons or for part of their life cycle. 
The variables Habitat Connections $\left(V_{C O N N E C T}\right)$, Interior Core Area $\left(V_{C O R E}\right)$, and Wetland Tract Area $\left(V_{T R A C T}\right)$ reflect landscape scale attributes of the wetland and of the landscape in which the wetland is located. The assumption is that the more habitat available, the more wildlife utilization will occur. Essentially, these variables represent two components, size and shape and isolation of the wetland. $V_{T R A C T}$ and $V_{C O R E}$ represent the size and shape of the wetland and are considered together. $V_{C O N N E C T}$ represents the isolation of the wetland from adjacent suitable habitats.

The habitat structure is represented by the individual componants $V_{M A C}, V_{P E R I}$, and $V_{\text {INVASIVE }}$ that are appropriate for each subclass. $V_{\text {COMP }}$ or $V_{\text {NATIVE }}$ represents the native species diversity.

Soil Surface Texture $\left(V_{\text {SURTEX }}\right)$, Soil Thickness $\left(V_{\text {SOILTHICK }}\right)$, and Microtopographic Features $\left(V_{\text {MICRO }}\right)$ are used in this function as an indication of habitat for invertebrates that live in the soil and as an indication of the site to be inundated.

In the first subpart of the equations, the landscape level features ( $V_{C O N N E C T}$, $V_{\text {CORE }}$, and $\left.V_{\text {TRACT }}\right)$ are considered equally and are averaged. In the second subpart of the equations, the soil features $\left(V_{\text {SURTEX }}, V_{\text {SOILTHICK, }}\right.$, and $\left.V_{\text {MICRO }}\right)$, depending on the subclass, are considered independently and of equal weight and consequently are averaged. Soil features are considered to exert an equivalent influence on the function; therefore, they are averaged with landscape. In the third subpart of the equations, $V_{M A C}, V_{P E R I}, V_{\text {INVASIVE }}$, and/or $\mathrm{V}_{\text {COMP }}$ or $\mathrm{V}_{\text {NATIVE }}$, depending on the subclass, represent the plant community structure. All components are considered of equal weight and are averaged. The onsite community represents the composition and structural components of habitat and is considered to exert a controlling influence on the function. Thus, the landscape and soils components are multiplied by the onsite community and averaged by a geometric mean. This arrangement of the aggregation equation reflects the assumption that site-specific aspects of habitat (i.e., biotic community/habitat structure) carry greater weight than landscape features. In other words, if the onsite community is degraded, the use of the wetland area by wildlife species will decrease even in a relatively unfragmented landscape with intact hydrology. 


\section{Assessment Protocol}

\section{Introduction}

Previous chapters of this Regional Guidebook provide background information on the HGM Approach, and document the variables, measures, and models used to assess the functions of Everglades wetlands. This chapter outlines a protocol for collecting and analyzing the data necessary to assess the functional capacity of a wetland in the context of a 404 permit review process or similar assessment scenario.

The typical assessment scenario is a comparison of preproject and postproject conditions in the wetland. In practical terms, this translates into an assessment of the functional capacity of the WAA under both preproject and postproject conditions and the subsequent determination of how FCIs have changed as a result of the project. Data for the preproject assessment are collected under existing conditions at the project site, while data for the postproject assessment are normally based on the conditions that are expected to exist following proposed project impacts. A skeptical, conservative, and well-documented approach is required in defining postproject conditions. This recommendation is based on the often-observed lack of similarity between predicted or "engineered" postproject conditions and actual postproject conditions.

This chapter discusses each of the tasks required to complete an assessment of Everglades wetlands:

a. Define assessment objectives

b. Characterize the project site

c. Screen for red flags

d. Define the Wetland Assessment Area

e. Collect field data

f. Analyze field data

g. Apply assessment results 


\section{Define Assessment Objectives}

Begin the assessment process by unambiguously identifying the purpose for conducting the assessment. This can be as simple as stating, "The purpose of this assessment is to determine how the proposed project will impact wetland functions." Other potential objectives could be as follows:

a. Compare several wetlands as part of an alternatives analysis.

$b$. Identify specific actions that can be taken to minimize project impacts.

c. Document baseline conditions at the wetland site.

d. Determine mitigation requirements.

e. Determine mitigation success.

f. Determine the effects of a wetland management technique.

\section{Characterize the Project Area}

Characterizing the project area involves describing the project area in terms of climate, surficial geology, geomorphic setting, surface and groundwater hydrology, vegetation, soils, land use, proposed impacts, and any other characteristics and processes that have the potential to influence how wetlands at the project area perform functions. The characterization should be written, and accompanied by maps and figures that show project area boundaries, jurisdictional wetlands, WAA (discussed later in this chapter), proposed impacts, roads, ditches, buildings, streams, soil types, plant communities, threatened or endangered species habitat, and other important features. Some information sources that will be useful in characterizing a project area are aerial photographs, topographic and NWI maps, and county soil surveys.

\section{Screen for Red Flags}

Red flags are features within or in the vicinity of the project area to which special recognition or protection has been assigned on the basis of objective criteria (Table 29). Many red flag features, such as those based on national criteria or programs, are similar from region to region. Other red flag features are based on regional or local criteria. Screening for red flag features represents a proactive attempt to determine if the wetlands or other natural resources in and around the project area require special consideration or attention that may preempt or postpone an assessment of wetland function. If a red flag feature exists, the assessment of wetland functions may not be necessary if the project is unlikely to occur as a result of the red flag feature. For example, if a proposed 


\begin{tabular}{|c|c|}
\hline \multicolumn{2}{|l|}{$\begin{array}{l}\text { Table } 29 \\
\text { Red Flag Features and Respective Program/Agency Authority }\end{array}$} \\
\hline Red Flag Features & Authority ${ }^{1}$ \\
\hline Native Lands and areas protected under American Indian Religious Freedom Act & A \\
\hline $\begin{array}{l}\text { Hazardous waste sites identified under Comprehensive Environmental Response, } \\
\text { Compensation, and Liability Act (Super Fund) (CERCLA) or Resource } \\
\text { Conservation and Recovery Act (RCRA) }\end{array}$ & $\mathrm{H}$ \\
\hline Areas protected by a Coastal Zone Management Plan & $\mathrm{D}$ \\
\hline Areas providing Critical Habitat for Species of Special Concern & $\mathrm{I}$ \\
\hline Areas covered under the Farmland Protection Act & $\mathrm{K}$ \\
\hline Floodplains, floodways, or floodprone areas & $\mathrm{J}$ \\
\hline Areas with structures/artifacts of historic or archeological significance & $\mathrm{F}$ \\
\hline Areas protected under the Land and Water Conservation Fund Act & $\mathrm{K}$ \\
\hline Areas protected by the Marine Protection Research and Sanctuaries Act & $\mathrm{D}$ \\
\hline National wildlife refuges and special management areas & $\mathrm{I}$ \\
\hline Areas identified in the North American Waterfowl Management Plan & I \\
\hline \multicolumn{2}{|l|}{ Areas identified as significant under the Ramsar Treaty } \\
\hline \multicolumn{2}{|l|}{ Areas supporting rare or unique plant communities } \\
\hline Areas designated as Sole Source Groundwater Aquifers & $\mathrm{I}$ \\
\hline \multicolumn{2}{|l|}{ Areas protected by the Safe Drinking Water Act } \\
\hline City, County, State, and National Parks & $\mathrm{F}, \mathrm{C}, \mathrm{L}$ \\
\hline Areas supporting threatened or endangered species & $\mathrm{B}, \mathrm{C}, \mathrm{E}, \mathrm{G}, \mathrm{I}$ \\
\hline \multicolumn{2}{|l|}{ Areas with unique geological features } \\
\hline \multicolumn{2}{|l|}{ Areas protected by the Wild and Scenic Rivers Act } \\
\hline \multicolumn{2}{|l|}{ Areas protected by the Wilderness Act } \\
\hline $\begin{array}{l}\text { Program Authority / Agency } \\
\text { A = Bureau of Indian Affairs } \\
B=\text { National Marine Fisheries Service (NMFS) } \\
\text { C = U.S. Fish and Wildlife Service } \\
D=\text { National Park Service (NPS) } \\
\text { E = State Coastal Zone Office } \\
\text { F = State Department of Natural Resources, Fish and Game, etc. } \\
\text { G = State Historic Preservation Officer (SHPO) } \\
\text { H = State Natural Heritage Offices } \\
\text { I = U.S. Environmental Protection Agency } \\
J=\text { Federal Emergency Management Administration } \\
K=\text { Natural Resources Conservation Service } \\
L=\text { Local Government Agencies }\end{array}$ & \\
\hline
\end{tabular}

project has the potential to impact a threatened or endangered species or habitat, an assessment of wetland functions may be unnecessary since the project may be denied or modified strictly on the basis of the impacts to threatened or endangered species or habitat.

\section{Define the Wetland Assessment Area}

The WAA is an area of wetland within a project area that belongs to a single regional wetland subclass, and is relatively homogeneous with respect to the sitespecific criteria used to assess wetland functions (i.e., hydrologic regime, vegetation structure, topography, soils, successional stage, etc.). In many project areas, there will be just one WAA representing a single wetland subclass as illustrated in Figure 60. However, as the size and heterogeneity of the project area increase, it is more likely that it will be necessary to define and assess multiple WAAs or PWAAs within a project area. 
At least three situations necessitate defining and assessing multiple PWAAs within a project area. The first situation exists when widely separated wetland patches of the same regional subclass occur in the project area (Figure 61). The second situation exists when more than one regional wetland subclass occurs within a project area (Figure 62). The third situation exists when a physically contiguous wetland area of the same regional subclass exhibits spatial heterogeneity with respect to hydrology, vegetation, soils, disturbance history, or other factors that translate into a significantly different value for one or more of the site-specific variable measures. These differences may be a result of natural variability (e.g., zonation on large river floodplains) or cultural alteration (e.g., logging, surface mining, hydrologic alterations) (Figure 63). Designate each of these areas as a separate PWAA and conduct a separate assessment on each area.

There are elements of subjectivity and practicality in determining what constitutes a significant difference in portions of the WAA. Field experience with the regional wetland subclass under consideration should provide the sense of the range of variability that typically occurs, and the common sense necessary to make reasonable decisions about defining multiple PWAAs. For example, in the Everglades, recently abandoned cropland

Project Area

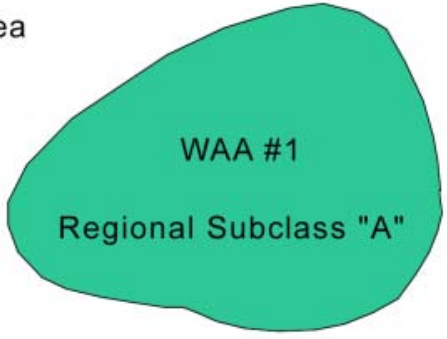

Figure 60. A single WAA within a project area

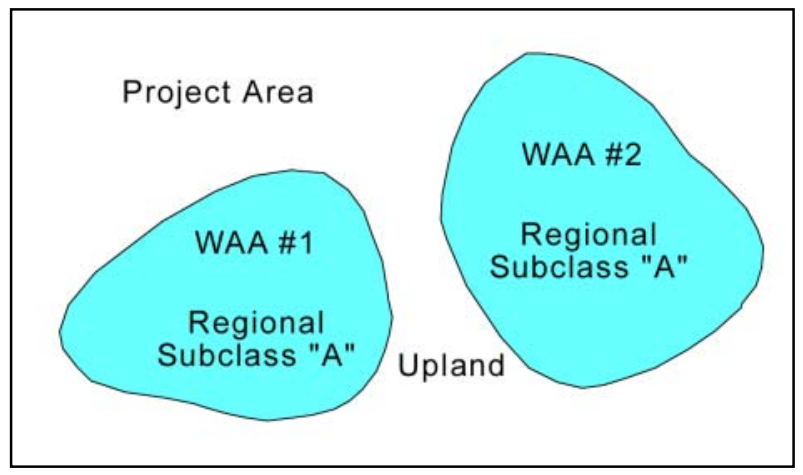

Figure 61. Spatially separated WAAs from the same regional wetland subclass within a project area

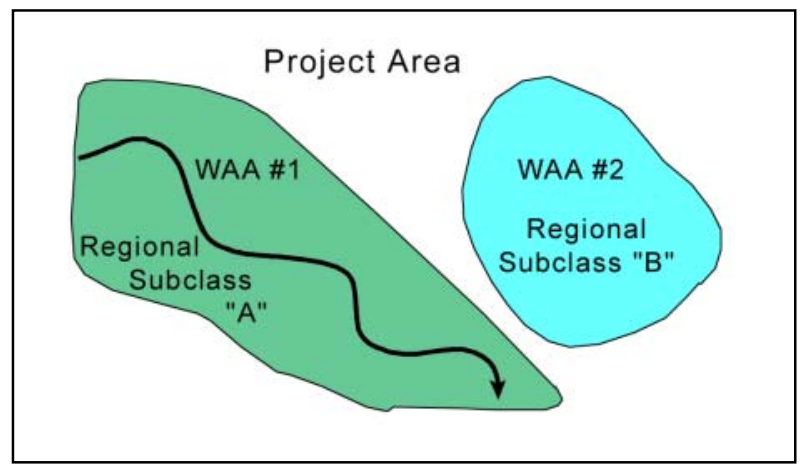

Figure 62. More than one regional wetland subclass within a project area will be a common criterion for designating two PWAAs in a wetland area. Splitting an area into many PWAAs in a project area based on relatively minor differences resulting from natural variability should not be used as a basis for dividing a contiguous wetland into multiple PWAAs. However, zonation caused by different hydrologic regimes or disturbances caused by rare and destructive natural events (i.e., hurricanes) should be used as a basis for defining PWAAs. 


\section{Determine Subclass}

This Guidebook describes three wetland subclasses found in the Everglades. Determining the correct subclass is primary to completing an HGM assessment. The subclasses are based on soils found on a site. Using the general soils map found in the county soil survey where the site is located, determine the regional subclass for the WAA. In Dade County, Florida, the soil associa-

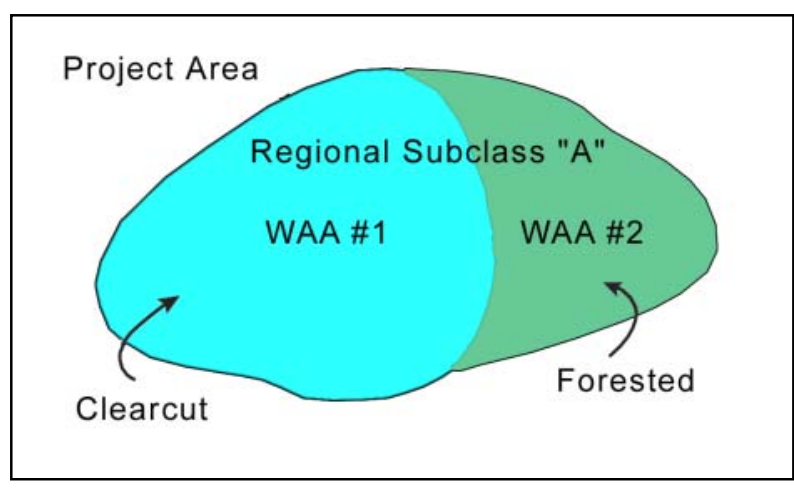

Figure 63. WAA defined based on differences in site-specific characteristics tion Lauderhill-Dania-Pahokee describes the Organic Flats subclass. The subclass should be verified by examining the soils onsite during field reconnaissance. Some areas (i.e., Everglades National Park) do not have soils information. In areas without published soils information, onsite examination of the soil during field reconnaissance will be necessary before the subclass can be determined.

\section{Collect Field Data}

The following equipment is necessary to collect field data:

a. Plant identification keys.

b. Soil probe/sharpshooter shovel.

c. A 50-m distance measuring tape, stakes, and flagging.

d. A $1-\mathrm{m}^{2}$ frame.

Information about the variables that are used to assess the function of Everglades wetlands is collected at several different spatial scales. The field data sheets shown in Figures 64-66 are organized to facilitate data collection at each spatial scale. Information about landscape scale variables (i.e., variables 1-4 on the field data sheet) such as $V_{T R A C T}$ is collected using aerial photographs, maps, and field reconnaissance of the area surrounding the WAA. Subsequently, information about the WAA in general (i.e., variable 4) is collected during a walking reconnaissance of the WAA. Finally, detailed, site-specific information (i.e., variables 5-11 or 5-12) is collected using sample plots at a number of representative locations throughout the WAA. 
Assessment Team:

Rocky Flats Everglades Field Data Sheet

Project Name:

Location:

Date:

Subclass: Rocky

Sample variables 1-4 using aerial photography, topographic maps, National Wetland Inventory maps, soils survey maps, etc.

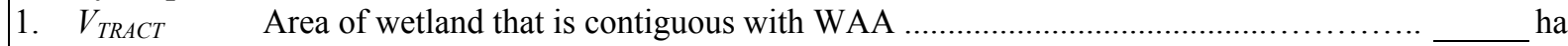

2. $V_{\text {CORE }} \quad$ Percent of wetland tract that is $>300 \mathrm{~m}$ from unsuitable habitat .........................

3. $V_{\text {CONNECT }}$ Percent of wetland tract perimeter that is "connected" to suitable habitat ...............

4. $V_{\text {MICRO }} \quad$ Percent of wetland area that has altered microtopographic features ......................

Sample variables 5-7 from a representative number of locations in the WAA using a 0.04-ha circular plot (11.3-m (37-ft) radius)

5. $V_{W O O D Y} \quad$ Percent cover of woody vegetation $\geq 1 \mathrm{~m}(3.3 \mathrm{ft})$ in height (average of 0.04 -ha values on next line)

Average of 0.04-ha plots sampled: $\_\% \%$

6. $V_{\text {INVASIVE }}$ Percent cover of invasive vegetation from all strata (average of 0.04-ha values on next line).

Average of 0.04-ha plots sampled:

$\%$

7. $V_{\text {NATIVE }}$ The total number of native wetland species in Rocky Everglades wetlands \#

Sample variables 8-11 in three (3) $1-\mathrm{m}^{2}$ subplots placed in representative locations of each quadrant of the 0.04-ha plot

8. $V_{M A C}$

Percent cover of emergent macrophytic vegetation (average of 0.04-ha values on next line).

Average of 0.04 -ha plots sampled:

\begin{tabular}{|c|c|c|}
\hline 1 & $\% 2$ & $\% 3$ \\
\hline 4 & $\% 5$ & $\% 6$ \\
\hline 7 & $\%$ & $\% 9$ \\
\hline
\end{tabular}

9. $V_{\text {PERI }}$ Percent cover of periphyton (average of $\overline{0.04}$-ha values on next line)

Average of 0.04-ha plots sampled:

\begin{tabular}{|c|c|c|}
\hline 1 & $\% 2$ & $\% 3$ \\
\hline 4 & $\% 5$ & $\% 6$ \\
\hline 7 & $\% 8$ & $\% 9$ \\
\hline
\end{tabular}

10. $V_{\text {SURTEX }}$ Soil texture of surface horizon or layer of the WAA as a percent (average of 0.04-ha values on next line).

Average of 0.04-ha plots sampled:

\begin{tabular}{|c|c|c|}
\hline 1 & $\% 2$ & $\% 3$ \\
\hline 4 & $\% 5$ & $\% 6$ \\
\hline & $\% 8$ & $\% 9$ \\
\hline
\end{tabular}
$\%$

11. VSOLTHICK Average soil thickness over limestone bedrock in centimeters (average of 0.04 -ha values on next line). $\mathrm{cm}$ Average of 0.04-ha plots sampled:

$\begin{array}{rrrr}1 & \% 2 & \% 3 & \% \\ 4 & \% 5 & \% 6 & \% \\ 7 & \% 8 & \% 9 & \%\end{array}$

Figure 64. Sample field data sheet for Rocky Flats Everglades wetlands 
Assessment Team:

Project Name:

Location:

Date:

Sample variables 1-4 using aerial photography, topographic maps, National Wetland Inventory maps, soils survey maps, etc.

1. $V_{T R A C T}$ Area of wetland that is contiguous with WAA. ha

2. $V_{C O R E}$ Percent of wetland tract that is $>300 \mathrm{~m}$ from unsuitable habitat $\%$

3. $V_{C O N N E C T}$ Percent of wetland tract perimeter that is "connected" to suitable habitat ..... $\%$

4. $V_{\text {MICRO }}$ Percent of wetland area that has altered microtopographic features ...... $\%$

Sample variables $5 \& 6$ from a representative number of locations in the WAA using a 0.04-ha circular plot (11.3-m (37-ft) radius)

5. $V_{\text {WOODY }}$ Percent cover of woody vegetation $\geq 1 \mathrm{~m}(3.3 \mathrm{ft})$ in height (average of 0.04-ha values on next line) Average of 0.04 -ha plots sampled: ___ $\%$ __ $\%$ $\%$

6. $V_{\text {INVASIVE }}$ Percent cover of invasive vegetation from all strata (average of 0.04-ha values on next line).

Average of 0.04-ha plots sampled: $\%$ $\%$ $\%$

Sample variables 8-12 in three (3) $1-\mathrm{m}^{2}$ subplots placed in representative locations of each quadrant of the 0.04-ha plot

8. $V_{M A C} \quad$ Percent cover of emergent macrophytic vegetation (average of 0.04-ha values on next line).....

Average of 0.04-ha plots sampled:

$\begin{array}{llll}1 & \% 2 & \% 3 & \% \\ 4 & \% 5 & \% 6 & \% \\ 7 & \% 8 & \% 9 & \%\end{array}$

9. $V_{\text {PERI }}$ Percent cover of periphyton (average of 0.04 -ha values on next line). $\%$ Average of 0.04-ha plots sampled:

$\begin{array}{rrrr}1 & \% 2 & \% 3 & \% \\ 4 & \% 5 & \% 6 & \% \\ 7 & \% 8 & \% 9 & \%\end{array}$

10. V VURTEX Soil texture of surface horizon or layer of the WAA as a percent (average of 0.04-ha values on next line) Average of 0.04-ha plots sampled:

\begin{tabular}{|c|c|c|}
\hline 1 & $\% 2$ & $\% 3$ \\
\hline 4 & $\% 5$ & $\% 6$ \\
\hline 7 & $\% 8$ & $\% 9$ \\
\hline
\end{tabular}

12. $V_{\text {СОMP }}$ Concurrence with dominants (average of 0.04 -ha values on next line)
Average of 0.04-ha plots sampled:

$1 \_\%$
$\% 5$
$\% 8$ $\% 3$
$\% 6$
$\% 9$

Figure 65. Sample field data sheet for Marl Flats Everglades wetlands 
Assessment Team:

Project Name:

Location:

Date:

Organic Flats Everglades Field Data Sheet

Sample variables 1-4 using aerial photography, topographic maps, National Wetland Inventory maps, soils survey maps, etc.

1. $V_{T R A C T}$ Area of wetland that is contiguous with WAA ha

2. $V_{C O R E}$ Percent of wetland tract that is $>300 \mathrm{~m}$ from unsuitable habitat $\%$

3. $V_{C O N N E C T}$ Percent of wetland tract perimeter that is "connected" to suitable habitat ......__ $\%$

4. VICRO Percent of wetland area that has altered microtopographic features ...............__ $\%$

Sample variables $5 \& 6$ from a representative number of locations in the WAA using a 0.04-ha circular plot (11.3-m (37-ft) radius)

5. $V_{W O O D Y}$ Percent cover of woody vegetation $\geq 1 \mathrm{~m}(3.3 \mathrm{ft})$ in height (average of 0.04-ha values on next line)

Average of 0.04-ha plots sampled: ___ $\%$ _ $\%$ $\%$

6. $V_{\text {INVASIVE }}$ Percent cover of invasive vegetation from all strata (average of 0.04-ha values on next line)

Average of 0.04-ha plots sampled: $\%$ $\%$

Sample variables $8,10, \& 12$ in three (3) $1-\mathrm{m}^{2}$ subplots placed in representative locations of each quadrant of the 0.04-ha plot

8. $V_{M A C}$ Percent cover of emergent macrophytic vegetation (average of 0.04-ha values on next line)

Average of 0.04-ha plots sampled:

\begin{tabular}{|c|c|c|}
\hline 1. & $\% 2$ & $\% 3$ \\
\hline 4 & $\% 5$ & $\% 6$ \\
\hline & $\% 8$ & $\% 9$ \\
\hline
\end{tabular}

10. $V_{\text {SURTEX }}$ Soil texture of surface horizon or layer of the WAA as a percent (average of 0.04-ha values on next line). Average of 0.04-ha plots sampled: 1

\begin{tabular}{|c|c|c|c|}
\hline 1 & $\% 2$ & $\% 3$ & - \\
\hline 4 & $\% 5$ & $\% 6$ & $\%$ \\
\hline 7 & $\% 8$ & $\% 9$ & 0 \\
\hline
\end{tabular}

12. $V_{\text {COMP }}$ Concurrence with dominants (average of 0.04 -ha values on next line) $\%$

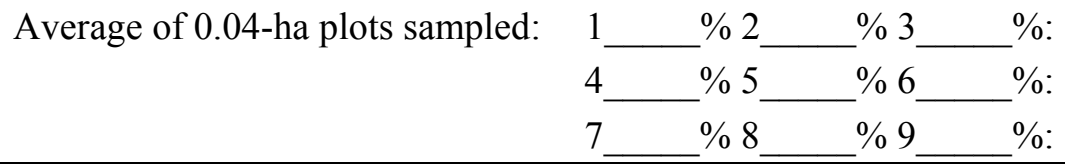

Figure 66. Sample field data sheet for Organic Flats Everglades wetlands 
Frequently, multiple purposes will be identified for conducting the assessment. Defining the purpose will facilitate communication and understanding among the people involved in conducting the assessment, and will make the purpose clear to other interested parties. In addition, it will help to establish the approach that is taken. The specific approach will vary to some degree depending on whether the project is a Section 404 permit review, an Advanced Identification (ADID), Special Area Management Plan (SAMP), or some other scenario.

After aerial photographs, topographic quads, soils maps, and NWI maps are acquired, the first step is to identify and delineate the WAA or PWAAs from locations provided and photo interpretation. Always use the best data available. If data are limited or questionable, the following procedures are recommended for gathering the necessary data in a timely manner.

The variables Microtopographic Features $\left(V_{\text {MICRO }}\right)$, Soil Thickness $\left(V_{\text {SOILTHICK }}\right)$, and Surface Soil Texture $\left(V_{\text {SURTEX }}\right)$ are disturbance variables, meaning that if no alteration has occurred onsite, then the subindex score will be 1.0.

The next step is to measure variables 1-4 using the equipment listed. It will usually be necessary to verify these measurements in the field during field reconnaissance.

An adjacent habitat is considered connected when it is directly adjacent to it and the width of this habitat class is at least $0.4 \mathrm{~km}$. If the width is less than $0.4 \mathrm{~km}$, then the next adjacent habitat class is considered to be the adjacent habitat class.

Next, divide the WAA or PWAA into four quadrants (Figure 67).

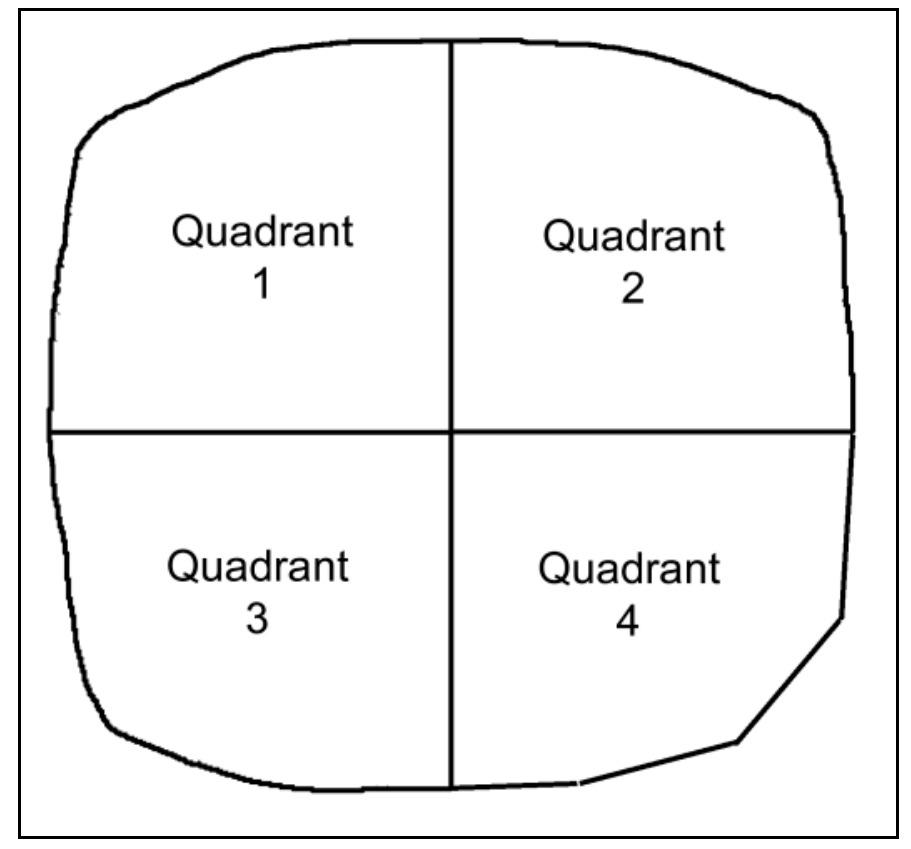

Figure 67. Divide the WAA in quadrants 
Variables 5-7 are measured in 11.3-m- (37.2-ft-) radius plots in at least three of the four quadrants (Figure 68). Locate the 11.3-m-radius plots in representative areas of the quadrant.

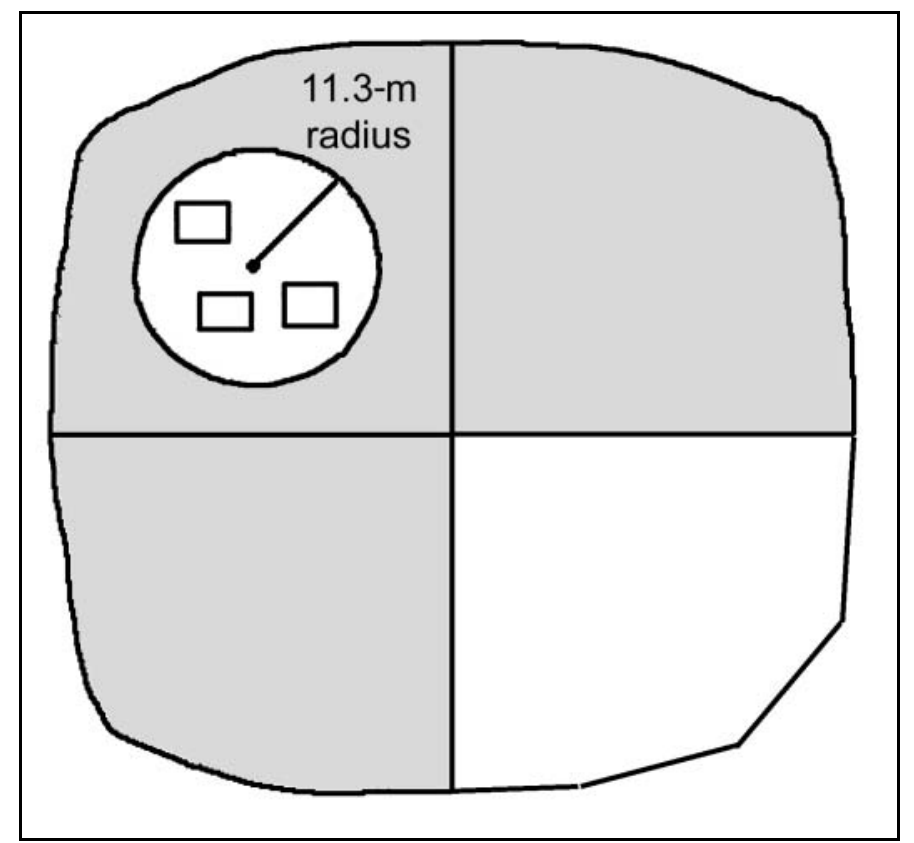

Figure 68. Select a minimum of three quadrants for sampling. Locate the 11.3-m-radius plots in representative areas of the quadrant and three $1-\mathrm{m}^{2}$ subplots within the plot

The number and layout of the plots are based on the size, shape, and complexity of the WAA or PWAA. Table 30 gives a recommended number of plots based on size of the WAA or PWAA. Some sites could be less than $22.6 \mathrm{~m}$ wide, and consequently the 11.3-m-radius plot would not fit within the boundaries of the WAA. In narrow sites 0.04 -ha (0.01-acre) sections could be sampled as plots. While three plots is considered a minimum number of plots for WAA or PWAAs greater than 0.32 ha, large sites may require more than three plots to adequately characterize the WAA. The number of plots should be based on the complexity of the site and is up to the discretion of the assessment team.

Variables 8-12 are measured in at least three $1-\mathrm{m}^{2}$ plots located in representative areas of the 11.3-m- (37.2-ft-) radius plots (Figure 69).

\begin{tabular}{|c|c|c|}
\hline \multicolumn{3}{|c|}{$\begin{array}{l}\text { Table } 30 \\
\text { Number of Plots per Area }\end{array}$} \\
\hline Size of WAA, ha & Number of Plots & Number of Subplots \\
\hline "s0.04 & $\begin{array}{l}\text { Entire site } \\
\end{array}$ & 3 \\
\hline$>0.04$ to 0.08 & 1 & 3 \\
\hline$>0.08$ to 0.16 & 2 & 6 \\
\hline$>0.16$ to 0.32 & 3 & 9 \\
\hline$>0.32$ & 3 minimum & 9 minimum \\
\hline
\end{tabular}




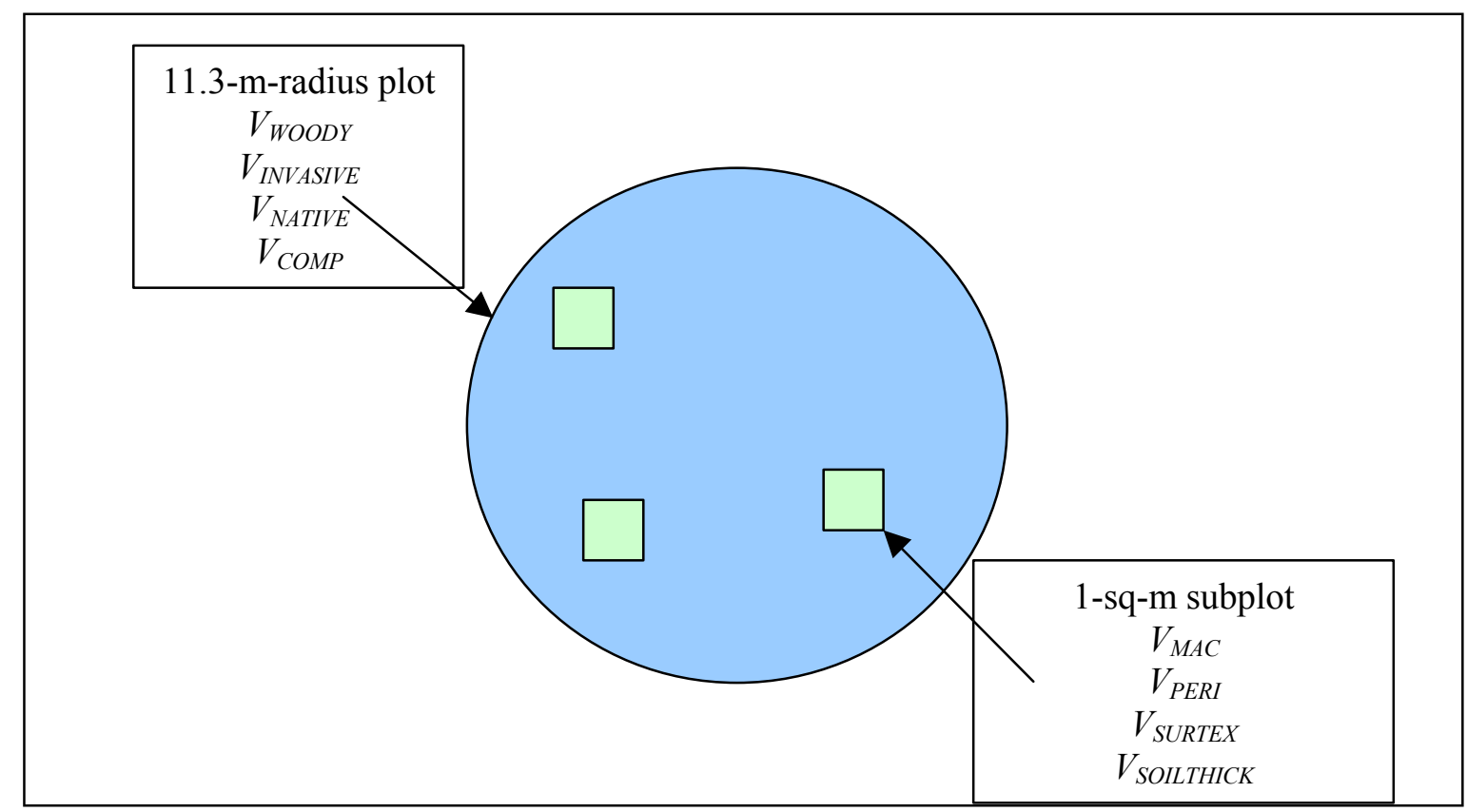

Figure 69. Sample plot and subplot dimensions and layout for field sampling

The location of the plots within the WAA or PWAAs should be in representative areas of different quadrants (Figure 69). As in defining the WAA or PWAAs, there are clearly elements of subjectivity and practical limitations in determining the number of sample locations for collecting plot-based, sitespecific data. Experience has shown that the time required to complete an assessment at a several-acre WAA or PWAA where three to four plots are sampled is 2 to $4 \mathrm{hr}$. Training and experience will reduce the required time to the lower end of this range.

\section{Analyze Field Data}

The analysis of field data requires two steps. The first step is to transform the measure of each assessment variable into a variable subindex. This can be done using the graphs in Appendix B or in a spreadsheet that has been set up to do the calculations automatically. The second step is to insert the variable subindices into the assessment model and calculate the FCI using the relationships defined in the assessment models. Again, this can be done manually or automatically, using a spreadsheet.

Figure 70 shows an example of a spreadsheet that has been set up to do both steps of the analysis. The data from the field data sheet is transferred into the second column of the lower half of the spreadsheet to the right of the variable names. The calculated variable subindex is displayed in the fourth column of the lower half of the spreadsheet. The variable subindices are then used to calculate the FCI using the appropriate assessment model. The resulting FCI is displayed 


\begin{tabular}{|c|c|c|c|}
\hline \multicolumn{4}{|c|}{ FCI Calculation for the Rocky Flats Everglades subclass. (5-10-02) } \\
\hline \multicolumn{4}{|c|}{ Enter quantitative or categorical measure from field data sheet in the blue-shaded cells below. } \\
\hline Variable & $\begin{array}{l}\text { Matric } \\
\text { Value Units }\end{array}$ & Subindex & \\
\hline$V_{T R A C T}$ & 1425 ha & 1 & \\
\hline$V_{\text {CORE }}$ & $100 \%$ & 1 & \\
\hline$V_{\text {CONNECT }}$ & $100 \%$ & 1 & $\mathrm{FCl}$ Function \\
\hline$V_{\text {MICRO }}$ & $100 \%$ & 0 & 0.5 Surface and Subsurface Water Storage \\
\hline$V_{\text {WOODY }}$ & $10 \%$ & 0.95 & 0.5 Cycle Nutrients \\
\hline$V_{I N V A S I V E}$ & $10 \%$ & 0.94 & 0.6 Characteristic Plant Community \\
\hline$V_{\text {NATIVE }}$ & $15 \#$ & 0.75 & 0.7 Wildlife Habitat \\
\hline$V_{M A C}$ & $37 \%$ & 1 & \\
\hline$V_{P E R I}$ & $88 \%$ & 1 & \\
\hline$V_{\text {SURTEX }}$ & $100 \%$ & 0.2 & \\
\hline$V_{\text {SOILTHICK }}$ & $4 \mathrm{~cm}$ & 1 & \\
\hline$V_{\text {COMP }}$ & N/A $\%$ & & \\
\hline
\end{tabular}

Figure 70. Example of an $\mathrm{FCl}$ calculation spreadsheet

in the first column of the top half of the spreadsheet to the left of each function name. The spreadsheet format allows the user to instantly ascertain how a change in the field measure of a variable will affect the FCI of a particular function by simply entering a new variable measure in the bottom half of the spreadsheet.

\section{Apply Assessment Results}

Once the assessment and analysis phases are complete, the results can be used to (a) compare the same WAA at different points in time, (b) compare different WAAs at the same point in time, (c) compare different alternatives to a project, or (d) compare different HGM classes or subclasses as per Smith et al. (1995) and Davis (1998b). 


\section{References}

Bancroft, G. T. (1989). "Status and conservation of wading birds in the Everglades," American Birds 43, 1258-1265.

Bancroft, G. T., Strong, A. M., Sawicki, R. J., Hoffman, W., and Jewell, S. D. (1994). "Relationships among wading bird foraging patterns, colony locations, and hydrology in the everglades," Everglades, 615-658.

Beaulac, N. M., and Reckhow, K. H. (1982). " "An examination of land usenutrient export relationships," Journal Water Resources Bulletin 18(6), 101324.

Bennetts, R. E., Collopy, M. W., and Rogers, J. S., Jr. (1994). "The snail kite in the Florida Everglades: A food specialist in a changing environment." Everglades: The ecosystem and its restoration. S. M. Davis and J. C. Ogden, ed., St. Lucie Press, Delray Beach, FL, Chapter 21.

Bodle, M. J., Ferriter, A. P., and Thayer, D. D. (1994). " "The biology, distribution and ecological consequences of Melaleuca quinquenervia in the Everglades." Everglades: The ecosystem and its restoration, S. M. Davis and J. C. Ogden, ed., St. Lucie Press, Delray Beach, FL, Chapter 14.

Bolen, E. G., Smith, L. H., and Schramm, H. L. (1989). "Playa lakes - prairie wetlands of the southern high plains," Bioscience 39, 615-23.

Brinson, M. M. (1993). "A hydrogeomorphic classification for wetlands," Technical Report WRP-DE-4, U.S. Army Engineer Waterways Experiment Station, Vicksburg, MS.

. (1995a). "Assessing wetland functions using HGM," National Wetlands Newsletter, January/February, Environmental Law Institute, Washington, DC.

. (1995b). "The hydrogeomorphic approach explained," National Wetlands Newsletter, November/December, Environmental Law Institute, Washington, DC. 
Brinson, M. M., Hauer, F. R., Lee, L. C., Nutter, W. L., Rheinhardt, R. D., Smith, R. D., and Whigham, D. (1995). "A guidebook for application of hydrogeomorphic assessments to riverine wetlands," Technical Report WRPDE-11, U.S. Army Engineer Waterways Experiment Station, Vicksburg, MS.

Brinson, M. M., Nutter, W. L., Rheinhardt, R., and Pruitt, B. A. (1996). "Background and recommendations for establishing reference wetlands in the Piedmont of the Carolinas and Georgia," EPA/600/R-96/057, U.S. Environmental Protection Agency National Health and Environmental Effects Laboratory, Western Division, Corvallis, OR.

Brinson, M. M., Smith, R. D., Whigham, D. F., Lee, L. C., Rheinhardt, R. D., and Nutter, W. L. (1998). "Progress in development of the hydrogeomorphic approach for assessing the functioning of wetlands." Proceedings, INTECOL International Wetland Conference. Perth, Australia.

Browder, J. A., Gleason, P. J., and Swift, D. R. (1994). "Periphyton in the Everglades: Spatial variation, environmental correlates and ecological implications." Everglades: The ecosystem and its restoration. S. M. Davis and J. C. Ogden, ed., St. Lucie Press, Delray Beach, FL, Chapter 16.

Carlisle, V. W., and Watts, F. C. (1995). "Factors of soil formation and Florida soils." Hydric soils of Florida handbook. $2^{\text {nd }}$ ed., V. W. Carlisle, ed., Florida Association of Environmental Soil Scientists, Gainesville, FL, 1-8.

Cooper, J. R., Watts, F. C., Cheng, D., and Lin, Z. (1995). "Problem soils: Man-altered and natural." Hydric soils of Florida handbook, $2^{\text {nd }}$ ed., V. W. Carlisle, ed., Florida Association of Environmental Soil Scientists, Gainesville, FL, 61-68.

Cowardin, L. M., Carter, V., Golet, F. C., and LaRoe, E. T. (1979). "Classification of wetlands and deepwater habitats of the United States," Report FWS/OBS-79/31, U.S. Fish and Wildlife Service, Office of Biological Services, Washington, DC.

Dahl, T. E. (2000). "Status and trends of wetlands in the conterminous United States 1986 to 1997," U.S. Department of the Interior, Fish and Wildlife Service. Washington, DC.

Dalrymple, N. K., Dalrymple, G. H., and Fanning, K. A. (1993). "Vegetation of restored rock-plowed wetlands of the East Everglades," Restoration Ecology, 220-25.

Davis, J. H., Jr. (1943). "The natural features of southern Florida, especially the vegetation, and the Everglades," Florida Geological Survey Bulletin, No. 25. 
Davis, M. "Hydrogeomorphic approach to assessing wetland functions: Guidelines for developing regional guidebooks; Chapter 5, Collecting and managing reference data" (in preparation), U.S. Army Engineer Research and Development Center, Vicksburg, MS.

Davis, M. M., and Ziewitz, J. (1998). "Evaluation of river management impacts on riparian wetland functions using the wetland hydrologic index." Engineering Approaches to Ecosystem Restoration. Proceedings of the American Society of Civil Engineers Wetlands Engineering and River Restoration Conference, Denver, CO, D. Hayes and J. C. Fischenick, ed., March 22-29, 1998.

Davis, S. M., Gunderson, L. H., Park, W. A., Richardson, J. R., and Mattson, J. E. (1994). "Landscape dimension, composition, and function in a changing Everglades ecosystem." Everglades: The ecosystem and its restoration. S. M. Davis and J. C. Ogden, ed., St. Lucie Press, Delray Beach, FL, Chapter 17.

Dohrenwend, R. E. (1977). "Evapotranspiration patterns in Florida," Florida Science 40, 184-92.

Douglas, M. S. (1947). The Everglades: River of grass (revised ed., 1988). Pineapple Press, Sarasota, FL.

Duever, M. J., Meeder, J. F., Meeder, L. C., and McCollum, J. M. (1994). "The climate of South Florida and its role in shaping the Everglades ecosystem." Everglades: The ecosystem and its restoration. S. M. Davis and J. C. Ogden, ed., St. Lucie Press, Delray Beach, FL, Chapter 9.

Environmental Laboratory. (1987). "Corps of Engineers wetlands delineation manual," Technical Report Y-87-1, U.S. Army Engineer Waterways Experiment Station, Vicksburg, MS.

Ewel, K. C., and Odum, H. T. ed., (1984). Cypress swamps. University Presses of Florida, Gainesville, FL.

Federal Register. (1997). "The National Action Plan to implement the Hydrogeomorphic Approach to assessing wetland functions," 62(119), June 20, 1997, 33607-33620.

Federico, A. D. (1977). "Investigations of the relationship between land use, rainfall, and runoff quality in the Taylor Creek watershed," Technical Publication 77-3, South Florida Water Management District, West Palm Beach, FL.

Ferren, W. R., Jr., Fiedler, P. L., and Leidy, R. A. (1996). "Wetlands of California. Part I. History of wetland habitat," Madrono 43, 105-24. 
Ferren, W. R., Jr., Fiedler, P. L., Leidy, R. A., Lafferty, K. D., and Mertes, L. A. K. (1996a). "Wetlands of California. Part II. Classification and description of wetlands of the central California and southern California coast and coastal watershed," Madrono 43, 125-82.

. (1996b). "Wetlands of California. Part III. Key to the catalogue of wetlands of the central California and southern California coast and coastal watershed," Madrono 43, 183-233.

Fish, J. E., and Stewart, M. (1991). "Hydrogeology of the surficial aquifer system, Dade County, FL," Water-Resources Investigations Report 90-4108, U.S. Geological Survey, Tallahassee, FL.

Florida Exotic Pest Plant Council. (2001). "List of Florida's invasive species," http://www.fleppc.org/01list.htm

Florida Natural Areas Inventory and Florida Department of Natural Resources. (1990). Guide to natural communities of Florida. Gainesville, FL.

Frederick, P. C., and Spalding, M. G. (1994). "Factors affecting reproductive success of wading birds in the Everglades ecosystem," Everglades, 659-692.

Gleason, P. J., and Spackman, W. (1974). "Calcareous periphyton and water chemistry in the Everglades." Environments of South Florida: Present and past. Memoir No. 2, P. J. Gleason, ed., Miami Geological Society, Miami, 146-81.

Gleason, P. J., and Stone, P. (1994). "Age, origin, and landscape evolution of the Everglades peatland." Everglades: The ecosystem and its restoration, S. M. Davis and J. C. Ogden, ed., St. Lucie Press, Delray Beach, FL, Chapter 7.

Golet, F. C., and Larson, J. S. (1974). "Classification of freshwater wetlands in the glaciated Northeast," Resources Publication 116, U.S. Fish and Wildlife Service.

Grubb, H. F., and Ryder, P. D. (1972). "Effects of coal mining on the water resources of the Tradewater River Basin, Kentucky," Geological Survey Water-Supply Paper 1940, U.S. Government Printing Office, Washington, DC.

Gunderson, L. H. (1994). "Vegetation of the Everglades: Determinants of community composition," Everglades: The ecosystem and its restoration, S. M. Davis and J. C. Ogden, eds., St. Lucie Press, Delray Beach, FL, Chapter 13. 
Harris, L. D., and Gosselink, J. G. (1990). "Cumulative impacts of bottomland hardwood forest conversion on hydrology, water quality, and terrestrial wildlife." Ecological processes and cumulative impacts illustrated by bottomland hardwood wetland ecosystems.

Hauer, F. R., and Smith, R D. (1998). "The hydrogeomorphic approach to functional assessment of riparian wetlands: Evaluating impacts and mitigation on river floodplains in the U.S.A." Freshwater Biology 40, 517-30.

Hoffman, W., Bancroft, G. T., and Sawicki, R. J. (1994). "Foraging habitat of wading birds in the water conservation areas of the Everglades." Everglades: The ecosystem and its restoration. S. M. Davis and J. C. Ogden, ed., St. Lucie Press, Delray Beach, FL, Chapter 24.

Hoffmeister, J. E. (1974). Land from the sea. University of Miami Press, Coral Gables, FL.

Hofstetter, R. H., and Sonenshein, R. S. (1990). "Vegetative changes in a wetland in the vicinity of a well field, Dade County, FL," Water Resources Investigations Report 89-4155, U.S. Geological Survey, Tallahassee, FL.

Holling, C. S., Gunderson, L. H., and Walters, J. (1994). "The structure and dynamics of the Everglades system: Guidelines for ecosystem restoration." Everglades: The ecosystem and its restoration. S. M. Davis and J. C. Ogden, eds. St. Lucie Press, Delray Beach, FL, Chapter 29.

Hubbard, D. E. (1988). "Glaciated prairie wetland functions and values: A synthesis of the literature," Biological Report 88(43), U.S. Fish and Wildlife Service, Washington, DC.

Kantrud, J. A., Krapu, G. L., Swanson, G. A. (1989). "Prairie basin wetlands of the Dakotas: A community profile," Biological Report 85, U.S. Fish and Wildlife Service, Washington, DC.

Kent, M., and Coker, P. (1995). Vegetation description and analysis, a practical approach. John Wiley and Sons, New York.

Kurz, H., and Wagner, K. A. (1953). "Factors in cypress dome development," Ecology 34, 157-64.

Kushlan, J. A. (1976). "Wading bird predation in a seasonally fluctuating pond," Auk 94:114-22.

. (1986). "Responses of wading birds to seasonally fluctuating water levels: Strategies and their limits," Colon. Waterbirds 9, 155-62.

. (1987). "External threats and internal management: The hydrologic regulation of the Everglades, Florida, USA," Environmental Management 11, 109-119. 
Kushlan, J. A. (1974). "The ecology of the white ibis in southern Florida: A regional study," Ph.D. diss., University of Miami, Coral Gables, FL.

Leibowitz, S. G., and Hyman, J. B. (1997). "Use of scale invariance in assessing the quality of judgement indicators," U.S. Environmental Protection Agency Laboratory, Corvallis, OR.

Liebowitz, S. G., Peterson, E. M., Arnaut, L. Y., Detenbeck, N. E., Hagley, C. A., Kentula, M. E., Olson, R. K., Sanville, W. D., and Sumner, R. R. (1992). "Wetlands research plan FY-92-96: An integrated risk-based approach," EPA/600/R-92-060, U.S. Environmental Protection Agency Laboratory, Corvallis, OR.

Light, S. S., and Dineen, J. W. (1994). "Water control in the Everglades: A historical perspective." Everglades: The ecosystem and its restoration. S. M. Davis and J. C. Ogden, ed., St. Lucie Press, Delray Beach, FL, Chapter 4.

Lodge, T. E. (1994). The Everglades handbook: Understanding the ecosystem. St. Lucie Press, Delray Beach, FL.

Loftus, W. F., and Eklund, A-M. (1994). "Long-term dynamics of an Everglades small-fish assemblage," Everglades: The ecosystem and its restoration. S. M. Davis and J. C. Ogden, ed., St. Lucie Press, Delray Beach, FL, Chapter 19.

Loveless, C. M. (1959). "A study of the vegetation of the Florida Everglades," Ecology 40: 1-9.

Ludwig, J. A., and Reynolds, J. F. (1988). Statistical ecology: A primer on methods and computing. John Wiley and Sons, New York.

MacArthur, R. H., and Wilson, E. O. (1967). The theory of island biogeography. Princeton Univ. Press, Princeton, NJ.

Mazzotti, F. J., and Brandt, L. A.. (1994). "Ecology of the American alligator in a seasonally fluctuating environment." Everglades: The ecosystem and its restoration. S. M. Davis and J. C. Ogden, ed., St. Lucie Press, Delray Beach, FL, Chapter 20.

McIvor, C. C., Ley, J. A., and Bjork, R. D. (1994). "Changes in freshwater inflow from the Everglades to Florida Bay including effects on biota and biotic processes: A review," Everglades: The ecosystem and its restoration. S. M. Davis and J. C. Ogden, ed., St. Lucie Press, Delray Beach, FL, Chapter 5.

McPherson, B. F., and Halley, R. (1996). The South Florida environment: A region under stress," U.S. Geological Survey Circular 1134, U.S. Geological Survey, Denver, CO. 
Mitsch, W. J., and Gosselink, J. G. (2000). Wetlands. $3^{\text {rd }}$ ed., John Wiley and Sons, New York.

Nesser, J. (1994). "Ecoregions and subregions of the United States," map, 1:7,500,000, region compilations by John Nesser et al., R. G. Bailey et al., ed., in cooperation with the ECOMAP Team of the Forest Service ; prepared by U.S. Geological Survey, Reston, VA.

Noble, C. V. (1989). "Marl soils in South Florida," Soil Survey Horizons 30, 12 16.

Odum, E. P. (1950). "Bird populations of the Highlands (North Carolina) Plateau in relation to plant succession and avian invasion," Ecology 31, 587605.

Odum, W. E., McIvor, C. C., and Smith, T. J. (1985). "The ecology of the mangroves of south Florida: A community profile," U.S. Fish and Wildlife Service, Washington, DC.

Ogden, J. C. (1994). "A comparison of wading bird nesting colony dynamics as an indication of ecosystem conditions in the southern Everglades." Everglades: The ecosystem and its restoration. S. M. Davis and J. C. Ogden, ed., St. Lucie Press, Delray Beach, FL, Chapter 22.

Ogden, J. C., Kushlan, J. A., and Tilmant, J. T. (1976). "Prey selectivity by wood stork," Condor 78, 324-330.

O’Hare, N. K., and Dalrymple, G. H. (1997). "Wildlife in southern Everglades wetlands invaded by melaleuca (Melaleuca quinquenervia)," Bulletin of the Florida Museum of Natural History 41, 1-68.

Ostry, R. C. (1982). "Relationship of water quality and pollutant loads to land uses in adjoining watersheds," Journal of Water Resources Bulletin 18(1), 99-104.

Rheinhardt, R. D., Brinson, M. M., and Farley, P. M. (1997). “A preliminary reference data set for wet forested flats in North Carolina and its application to wetland functional assessment, mitigation, and restoration," Wetlands 17 , 195-215.

Scheidt, D. J., Flora, M. D., and Walker, D. R. (1987). "Water quality management for Everglades National Park." North American Lakes Management Society 75th Int. Symp., Orlando, Nov 4, 1987.

Schneider, D. C. (1994). Quantitative ecology: Spatial and temporal scaling. Academic Press, New York. 
Science Subgroup. (1994). "South Florida ecosystem restoration: Scientific information needs," Draft, September 27, 1994, Management and Coordination Working Group, Interagency Task Force on the South Florida Ecosystem.

Semeniuk, C. A. (1987). "Wetlands of the Darling System: A geomorphic approach to habitat classification," Journal of the Royal Society of Western Australia 69, 95-112.

Shafer, D. J., and Yozzo, D. J. (1998). "National guidebook for application of hydrogeomorphic assessment to tidal fringe wetlands," Technical Report WRP-DE-16, U.S. Army Engineer Waterways Experiment Station, Vicksburg, MS.

Shahan, A. N. (1982). "Estimation of pre- and post-development nonpoint water quality loadings," Journal of Water Resources Bulletin 18, 231-37.

Sinsch, U. (1990). "Migration and orientation in anuran amphibians," Ethology, Ecology, and Evolution 2, 65-79.

Smith, R. D. (2001). "Hydrogeomorphic approach to assessing wetland functions: Guidelines for developing regional guidebooks; Chapter 3, Developing a reference wetland system," ERDC/EL TR-01-29, U.S. Army Engineer Research and Development Center, Vicksburg, MS.

Smith, R. D., Amman, A., Bartoldus, C., and Brinson, M. M. (1995). “An approach for assessing wetland functions based on hydrogeomorphic classification, reference wetlands, and functional indices," Technical Report WRPDE-9, U.S. Army Engineer Waterways Experiment Station, Vicksburg, MS.

Smith, R. D., and Wakeley, J. S. (2001). "Hydrogeomorphic approach to assessing wetland functions: Guidelines for developing regional guidebooks; Chapter 4, Developing assessment models," ERDC/EL TR-01-30, U.S. Army Engineer Research and Development Center, Vicksburg, MS.

Snyder, G. H., and Davidson, J. M. (1994). "Everglades agriculture: Past, present, and future." Everglades: The ecosystem and its restoration. S. M. Davis and J. C. Ogden, ed., St. Lucie Press, Delray Beach, FL, Chapter 5.

Sorenson, T. A. (1948). "A method of establishing groups of equal amplitude in plant sociology based on similarity of species content, and its application to analyses of the vegetation on Danish commons," Kongelige Danske Videnskabernes Selskab Biologiske Skrifter 56, 1-34.

South Florida Water Management District. (1993). Working document in support of the Lower East Coast Regional Water Supply Plan. West Palm Beach, FL. 
Stewart, K. K., and Ornes, W. H. (1975). “Assessing a marsh environmental for wastewater renovation," Journal of Water Pollution Control Fed. 47, 188091.

Stewart, R. E., and Kantrud, H. A. (1971). "Classification of natural ponds and lakes in the glaciated prairie region," Resource Publication 92, U.S. Fish and Wildlife Service, Washington, DC.

Strecker. E. W., Kernar, J. M., Driscoll, E. D., Horner, R. R., and Davenport, T. E. (1992). "The use of wetlands for controlling stormwater pollution," The Terrene Institute, Alexandria, VA.

Swift, D. R., and Nicholas, R. B. (1987). "Periphyton and water quality relationships in the Everglades Water Conservation Areas," Technical Publication 87-2, South Florida Water Management District, West Palm Beach, FL.

ter Braak, C. J. F. (1994). "Canonical community ordination. Part 1: Basic theory and linear methods," Ecoscience 1, 127-140.

Terry, R. D., and Chilingar, G. V. (1995). "Summary of 'Concerning some additional aids in studying sedimentary formations' by M. S. Shvetsov," Journal of Sedimentary Petrology 25(3), 229-234.

Thomas, T. M. (1974). "A detailed analysis of climatological and hydrological records of South Florida with reference to man's influence upon the ecosystem evolution," Environments of South Florida: Present and past.

Memoir 2, P. J. Gleason, ed., Miami Geological Society, Miami, FL.

Tropical BioIndustries, Inc. (1990). "Hydroperiod conditions of key environmental indicators of Everglades National Park and adjacent East Everglades area as guide to selection of an optimum water plan for Everglades National Park, Florida," performed under Contract No. DACW 17-84-C-0031for U.S. Army Engineer District, Jacksonville, Jacksonville, FL, by Tropical BioIndustries, Inc., Miami, FL.

U.S. Department of Agriculture. (1978). "Soil survey for Palm Beach County, Florida," Soil Conservation Service.

. (1981). "Land resource regions and major land resource areas of the United States," Agriculture Handbook 296, Washington, DC.

. (1984a). "Soil survey of Broward County, Florida," Soil

Conservation Service, Washington, DC.

. (1984b). "Soil survey of Lee County, Florida," Soil Conservation Service, Washington, DC.

. (1990). "Soil survey of Hendry County, Florida," Soil

Conservation Service, Washington, DC. 
U.S. Department of Agriculture. (1996). "Soil survey of Dade County, Florida," Soil Conservation Service, Washington, DC.

. (1998). "Soil survey of Collier County, Florida," Soil

Conservation Service, Washington, DC.

. (1999). "Soil taxonomy: A basic system of soil classification for making and interpreting soil surveys." Agricultural Handbook 436, Natural Resources Conservation Service.

U.S. Fish and Wildlife Service. (1988). "National list of vascular plant species that occur in wetlands," U.S. Fish and Wildlife Service Biological Report 88 (24).

Van Meter-Kasanof, N. (1973). "Ecology of microalgae of the Florida Everglades, Part I. Environment and some aspects of freshwater periphyton, 1959 to 1963," Nova Hedwigia 24, 619-664.

Vymazal, J., and Richardson, C. J.. (1995). "Species composition, biomass and nutrient content of periphyton in the Florida Everglades," Journal Phycol. $31,343-54$.

Wade, D. D., Ewel, J. J., and Hofstetter, R. H. (1980). "Fire in south Florida ecosystems," General Technical Report SE-17, U.S. Department of Agriculture, U.S. Forest Service, Southern Research Station, Asheville, NC.

Wakeley, J. S., and Smith, R. D. (2001). "Hydrogeomorphic approach to assessing wetland functions: Guidelines for developing regional guidebooks; Chapter 7, Verifying, field testing, and validating assessment models," ERDC/EL TR-01-31, U.S. Army Engineer Research and Development Center, Vicksburg, MS.

Wharton, C. H., Kitchens, W. M., Pendleton, E. C., and Sipe, T. W. (1982).

"The ecology of bottomland hardwood swamps of the southeast: A community profile," Report FWS/OBS-81/37, U.S. Fish and Wildlife Service, Office of Biological Services, Washington, DC.

White, P. S. (1994). "Synthesis: Vegetation pattern and process in the Everglades ecosystem." Everglades: The ecosystem and its restoration. S. M. Davis and J. C. Ogden, ed., St. Lucie Press, Delray Beach, FL, Chapter 18.

Zarbock, H., Janicki, A., Wade, D., Heimbuch, D., and Wilson, H. (1994). "Estimates of total nitrogen, total phosphorus, and total suspended solids loadings to Tampa Bay, Florida," Tampa Bay National Estuary Program, St. Petersburg, FL.

Zedler, P. H. (1987). "The ecology of southern California vernal pools: A community profile," Biological Report 85(7.11), U.S. Fish and Wildlife Service, Washington, DC. 


\title{
Appendix A Glossary
}

\begin{abstract}
Abiotic: Not biological.
Assessment model: A simple model that defines the relationship between ecosystem and landscape scale variables and functional capacity of a wetland. The model is developed and calibrated using reference wetlands from a reference domain.
\end{abstract}

Assessment objective: The reason why an assessment of wetland functions is being conducted. Assessment objectives normally fall into one of three categories: documenting existing conditions, comparing different wetlands at the same point in time (e.g., alternatives analysis), and comparing the same wetland at different points in time (e.g., impact analysis or mitigation success).

Assessment team (A-Team): An interdisciplinary group of regional and local scientists responsible for classification of wetlands within a region, identification of reference wetlands, construction of assessment models, definition of reference standards, and calibration of assessment models.

Biotic: Of or pertaining to life; biological.

Direct impacts: Project impacts that result from direct physical alteration of a wetland, such as the placement of dredge or fill.

Direct measure: A quantitative measure of an assessment model variable.

\section{Exotics: See Invasive Species.}

Facultative (FAC): Equally likely to occur in wetlands or nonwetlands (estimated probability 34-66 percent).

Facultative wetland (FACW): Usually occurs in wetlands (estimated probability 67-99 percent), but occasionally found in nonwetlands.

Functional assessment: The process by which the capacity of a wetland to perform a function is measured. This approach measures capacity using an assessment model to determine a functional capacity index. 
Functional capacity: The rate or magnitude at which a wetland ecosystem performs a function. Functional capacity is dictated by characteristics of the wetland ecosystem and the surrounding landscape, and interaction between the two.

Functional Capacity Index (FCI): An index of the capacity of a wetland to perform a function relative to other wetlands in a regional wetland subclass. Functional capacity indices are by definition scaled from 0.0 to 1.0. An index of 1.0 indicates the wetland is performing a function at the highest sustainable functional capacity, the level equivalent to a wetland under reference standard conditions in a reference domain. An index of 0.0 indicates the wetland does not perform the function at a measurable level, and will not recover the capacity to perform the function through natural processes.

Highest sustainable functional capacity: The level of functional capacity achieved across the suite of functions by a wetland under reference standard conditions in a reference domain. This approach assumes that the highest sustainable functional capacity is achieved when a wetland ecosystem and the surrounding area are undisturbed.

Hydrogeomorphic wetland class: The highest level in the hydrogeomorphic wetland classification. There are five basic hydrogeomorphic wetland classes: depression, riverine, slope, fringe, and flat.

Hydrogeomorphic unit: Hydrogeomorphic units are areas within a wetland assessment area that are relatively homogeneous with respect to ecosystem scale characteristics such as microtopography, soil type, vegetative communities, or other factors that influence function. Hydrogeomorphic units may be the result of natural or anthropogenic processes. See Partial wetland assessment area.

Hydroperiod: The annual duration of flooding (in days per year) at a specific point in a wetland.

Indicator: Indicators are observable characteristics that correspond to identifiable variable conditions in a wetland or the surrounding landscape.

Indirect measure: A qualitative measure of an assessment model variable that corresponds to an identifiable variable condition.

Indirect impacts: Impacts resulting from a project that occur concurrently, or at some time in the future, away from the point of direct impact. For example, indirect impacts of a project on wildlife can result from an increase in the level of activity in adjacent, newly developed areas, even though the wetland is not physically altered by direct impacts.

Invasive species: Generally exotic species without natural controls that outcompete native species. 
Jurisdictional wetland: Areas that meet the soil, vegetation, and hydrologic criteria described in the "Corps of Engineers Wetlands Delineation Manual" (Environmental Laboratory 1987), ${ }^{1}$ or its successor.

Marl: A limnic layer (composed of organic and inorganic materials) with a moist Munsell color value of 5 or more that reacts with dilute $\mathrm{HCl}$ to evolve $\mathrm{CO}_{2}$.

Mitigation: Restoration or creation of a wetland to replace functional capacity that is lost as a result of project impacts.

Mitigation plan: A plan for replacing lost functional capacity resulting from project impacts.

Mitigation wetland: A restored or created wetland that serves to replace functional capacity lost as a result of project impacts.

Model variable: A characteristic of the wetland ecosystem or surrounding landscape that influences the capacity of a wetland ecosystem to perform a function.

Obligate wetland $(\mathrm{OBL})$ : Occurs almost always (estimated probability 99 percent) under natural conditions in wetlands.

Oligotrophic: Environments in which the concentration of nutrients available for growth is limited. Nutrient-poor habitats.

Organic matter: Plant and animal residue in the soil in various stages of decomposition.

Organic soil material: Soil material that is saturated with water for long periods or artificially drained and, excluding live roots, has an organic carbon content of 18 percent or more with 60 percent or more clay, or 12 percent or more organic carbon with 0 percent clay. Soils with an intermediate amount of clay have an intermediate amount of organic carbon. If the soil is never saturated for more than a few days, it contains 20 percent or more organic carbon.

Organic soils (Histosol): A soil of which more than half of the upper $80 \mathrm{~cm}$ (32 in.) of the soil is organic or if organic soil material of any thickness rests on rock or on fragmental material having interstices filled with organic material.

Oxidation: The loss of one or more electrons by an ion or molecule.

Partial wetland assessment area (PWAA): A portion of a WAA that is identified a priori, or while applying the assessment procedure, because it is relatively homogeneous and different from the rest of the WAA with respect to one or more model variables. The difference may occur naturally or as a result of anthropogenic disturbance. See Hydrogeomorphic unit.

\footnotetext{
${ }^{1}$ References cited in this Appendix are listed in Chapter 6, "References."
} 
Peat (geologic definition): Unconsolidated soil material consisting largely of undecomposed, or slightly decomposed, organic matter accumulated under conditions of excessive moisture. Includes muck, mucky peat, and peat.

Periphyton: A submerged algal mat composed primarily of green and bluegreen algae formed annually on sites that are inundated.

Project alternative(s): Different ways in which a given project can be done. Alternatives may vary in terms of project location, design, method of construction, amount of fill required, and other ways.

Project area: The area that encompasses all activities related to an ongoing or proposed project.

Project target: The level of functioning identified for a restoration or creation project. Conditions specified for the functioning are used to judge whether a project reaches the target and is developing toward site capacity.

Red flag features: Features of a wetland or the surrounding landscape to which special recognition or protection is assigned on the basis of objective criteria. The recognition or protection may occur at a Federal, State, regional, or local level and may be official or unofficial.

Reference domain: All wetlands within a defined geographic area that belong to a single regional wetland subclass.

Reference standards: Conditions exhibited by a group of reference wetlands that correspond to the highest level of functioning (highest sustainable capacity) across the suite of functions of the regional wetland subclass. By definition, highest levels of functioning are assigned an index of 1.0.

Reference wetlands: Wetland sites that encompass the variability of a regional wetland subclass in a reference domain. Reference wetlands are used to establish the range of conditions for construction and calibration of functional indices and to establish reference standards.

Region: A geographic area that is relatively homogeneous with respect to largescale factors such as climate and geology that may influence how wetlands function.

Regional canals: Canals that provide drainage for a regional area by accepting inflows from secondary canals and ditches. For the glades model, regional canals are those identified by the South Florida Water Management District (SFWMD) as "large conveyance system." A map identifying the regional canals can be found on the SFWMD website: www.sfwmd.gov/org/clm/row/images/pdfs/strucloc.pdf 
Regional wetland subclass: Regional hydrogeomorphic wetland classes that can be identified based on landscape and ecosystem scale factors. There may be more than one regional wetland subclass for each of the hydrogeomorphic wetland classes that occur in an region, or there may be only one.

Rock plowing: Process by which limestone rock and marl are ground into a mixture of coarse and fine particles to form a "soil" in the rocky glades.

Seasonal high water table: The shallowest depth to free water that stands in an unlined borehole or where the soil moisture tension is zero for a significant period (for more than a few weeks).

Solution holes: Small sinkholes that are filled with soil and surrounded by rock outcrop.

Site potential: The highest level of functioning possible, given local constraints of disturbance history, land use, or other factors. Site capacity may be equal to or less than levels of functioning established by reference standards for the reference domain, and it may be equal to or less than the functional capacity of a wetland ecosystem.

Soil surface: The soil surface is the top of the mineral soil; or, for soils with an O horizon, the soil surface is the top of the part of the $\mathrm{O}$ horizon that is at least slightly decomposed. Fresh leaf or needle fall that has not undergone observable decomposition is excluded from soil and may be described separately (Carlisle and Collins 1995).

Value of wetland function: The relative importance of wetland function or functions to an individual or group.

Variable: An attribute or characteristic of a wetland ecosystem or the surrounding landscape that influences the capacity of the wetland to perform a function.

Variable condition: The condition of a variable as determined through quantitative or qualitative measure.

Variable index: A measure of how an assessment model variable in a wetland compares to the reference standards of a regional wetland subclass in a reference domain.

\section{Wetland: See Wetland ecosystems.}

Wetland ecosystems: In 404: “........areas that are inundated or saturated by surface or ground water at a frequency and duration sufficient to support, and that under normal circumstances do support, a prevalence of vegetation typically adapted for life in saturated soil conditions. Wetlands generally include swamps, marshes, bogs, and similar areas" (Corps Regulation 33 CFR 328.3 and EPA Regulations 40 CFR 230.3). In a more general sense, wetland ecosystems are 
three-dimensional segments of the natural world where the presence of water at or near the surface creates conditions leading to the development of redoximorphic soil conditions, and the presence of a flora and fauna adapted to the permanently or periodically flooded or saturated conditions.

Wetland assessment area (WAA): The wetland area to which results of an assessment are applied.

Wetland functions: The normal activities or actions that occur in wetland ecosystems, or simply, the things that wetlands do. Wetland functions result directly from the characteristics of a wetland ecosystem and the surrounding landscape, and their interaction.

Wetland restoration: The process of restoring wetland function in a degraded wetland. Restoration is typically done as mitigation. 


\section{Appendix B Summaries and Forms for Field Use}

This appendix contains the following information summaries and example sheets:

a. Summary of Functions for Everglades Flats Wetlands - page B2

b. Summary of Model Variables, Measure/Units, and Methods - page B7

c. Summary of Variables by Function - page B17

d. Summary of Graphs for Transforming Measures to Subindices page $\mathrm{B} 19$

e. Blank Field Data Sheet - page B26 


\section{Summary of Functions for Everglades Wetlands}

\section{Function 1: Surface and Subsurface Water Storage}

a. Definition. Surface and Subsurface Water Storage is defined as the presence of conditions that allow water source, storage, and outflow dynamics to occur in a manner typical of the three Everglades Flats wetland subclasses. Precipitation is the primary source of water in the Everglades. The function should be validated using a correlation of the Functional Capacity Index (FCI) for this function with a hydrologic similarity index calculated for several Everglade wetland sites. The hydrologic similarity index compares season, depth, and frequency of inundation of assessed and reference standard sites (Davis and Ziewitz 1998). ${ }^{1}$

b. Model variables - symbols - measures - units.

(1) Surface Soil Texture - $V_{\text {SURTEX }}$ - U.S. Department of Agriculture textural class or term used in lieu of texture of the surface soil horizon - unitless.

(2) Soil Thickness (Rocky Flats wetlands subclass only) $-V_{\text {SOILTHICK }}-$ total thickness of the soil over limestone rock - centimeters.

(3) Microtopographic Features $-V_{M I C R O}$ - percent of the area with altered microtopographic features - unitless.

(4) Cover of Woody Vegetation $-V_{W O O D Y}-$ percent cover of woody vegetation - unitless.

(5) Periphyton Cover (Rocky and Marl Flats wetlands subclasses only) $V_{P E R I}-$ percent cover of periphyton - unitless.

c. Assessment model:

(1) For Rocky Flats Everglades wetlands:

$$
F C I=\left[\frac{V_{\text {SURTEX }}+V_{\text {SOILTHICK }}+V_{\text {MICRO }}+\left(\frac{V_{\text {WOODY }}+V_{\text {PERI }}}{2}\right)}{4}\right]
$$

(2) For Marl Flats Everglades wetlands:

\footnotetext{
${ }^{1}$ References cited in this Appendix are listed in Chapter 6, "References."
} 


$$
F C I=\left[\frac{V_{\text {SURTEX }}+V_{\text {MICRO }}+\left(\frac{\left.V_{\text {WOODY }}+V_{\text {PERI }}\right)}{2}\right)}{3}\right]
$$

(3) For Organic Flats Everglades wetlands:

$$
F C I=\left(\frac{V_{\text {SURTEX }}+V_{\text {MICRO }}+V_{\text {WOODY }}}{3}\right)
$$

\section{Function 2: Cycle Nutrients}

a. Definition. The function is defined as the characteristic biotic and abiotic processes of the Everglades wetlands that alter concentrations of imported nutrients and compounds in the water leaving the wetland in comparison with water entering the wetland. These processes include conversion of nutrients and other elements and compounds from one form into another by assimilation into plant biomass, remineralization of those materials when the plant materials decompose, long-term storage of nutrients and compounds in mineral and organic soil fractions, and oxygen production. The function can be validated using correlation of the function FCI with the differences in amounts of dissolved nutrients and compounds (tons/ha/year) in inflowing and outflowing water to and from the assessed wetland.

b. Model variables - symbols - measures - units.

(1) Surface Soil Texture - $V_{\text {SURTEX }}$ - U.S. Department of Agriculture textural class or term used in lieu of texture of the surface soil horizon - unitless.

(2) Microtopographic Features $-V_{\text {MICRO }}-$ percent of the area with altered microtopographic features - unitless.

(3) Emergent Macrophytic Vegetation Cover $-V_{M A C}-$ percent cover of macrophytic vegetation - unitless.

(4) Periphyton Cover (Rocky and Marl Flats wetlands subclasses only) $V_{P E R I}$ - percent cover of periphyton - unitless.

(5) Number of Native Wetland Species (Rocky Flats wetlands subclass only) $-V_{\text {NATIVE }}$ - total number of native wetland species - unitless.

(6) Plant Species Composition (Marl and Organic Flats wetlands subclasses only) $-V_{C O M P}-$ percent concurrence with dominant species by strata - unitless. 
(1) For Rocky Flats Everglades wetlands:

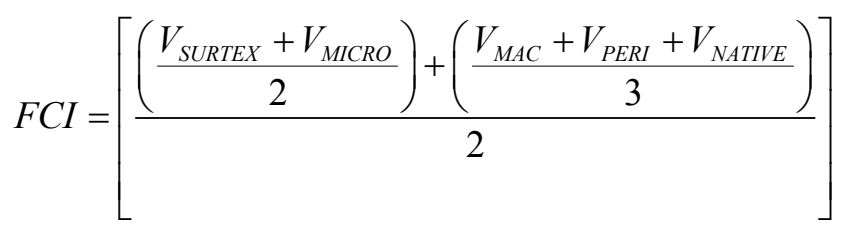

(2) For Marl Flats Everglades wetlands

$F C I=\left[\frac{\left(\frac{\left.V_{\text {SURTEX }}+V_{\text {MICRO }}\right)}{2}\right)+\left(\frac{V_{M A C}+V_{\text {PERI }}+V_{\text {COMP }}}{3}\right)}{2}\right]$

(3) For Organic Flats Everglades wetlands

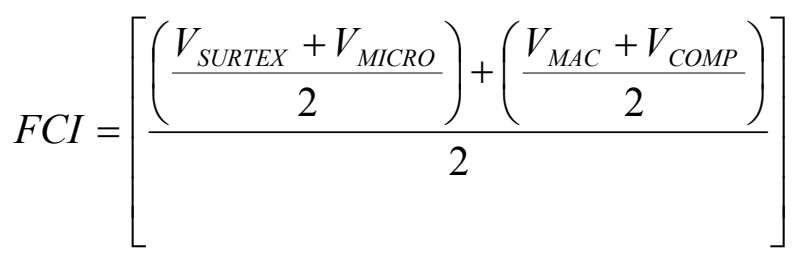

\section{Function 3: Characteristic Plant Community}

a. Definition. Maintain Characteristic Plant Community is defined as the capacity of an Everglades wetland to provide the environment necessary for a characteristic plant community to develop and be maintained. In assessing this function, one must consider both the extant plant community as an indication of current conditions and the physical factors that determine whether or not a characteristic plant community is likely to be maintained in the future. Potential independent, quantitative measures of this function, based on vegetation composition and abundance, include similarity indices (Ludwig and Reynolds 1988) or ordination axis scores from detrended correspondence analysis or other multivariate technique (Kent and Coker 1995). A potential independent, quantitative measure of this function, based on vegetation composition and abundance as well as environmental factors, is ordination axis scores from canonical correlation analysis (ter Braak 1994).

b. Model variables - symbols - measures - units.

(1) Emergent Macrophytic Vegetation Cover $-V_{M A C}-$ percent cover of macrophytic vegetation - unitless. 
(2) Periphyton Cover (Rocky and Marl Flats wetlands subclasses only) $V_{P E R I}$ - percent cover of periphyton - unitless.

(3) Invasive Vegetation Cover - $V_{\text {INVASIVE }}$ - percent cover of invasive vegetation - unitless.

(4) Number of Native Wetland Secies (Rocky Flats wetlands subclass only) $-V_{\text {NATIVE }}$ - total number of native wetland species - unitless.

(5) Plant Species Composition (Marl and Organic Flats wetlands subclasses only) $-V_{\text {COMP }}-$ percent concurrence with dominant species by strata - unitless.

(6) Surface Soil Texture - $V_{\text {SURTEX }}$ - U.S. Department of Agriculture textural class or term used in lieu of texture of the surface soil horizon - unitless.

(7) Soil Thickness (Rocky Flats wetlands subclass only) $-V_{\text {SOILTHICK }}-$ total thickness of the soil over limestone rock - centimeters.

(8) Microtopographic Features $-V_{M I C R O}$ - percent of the area with altered microtopographic features - unitless.

c. Assessment model:

(1) For Rocky Flats Everglades Wetlands

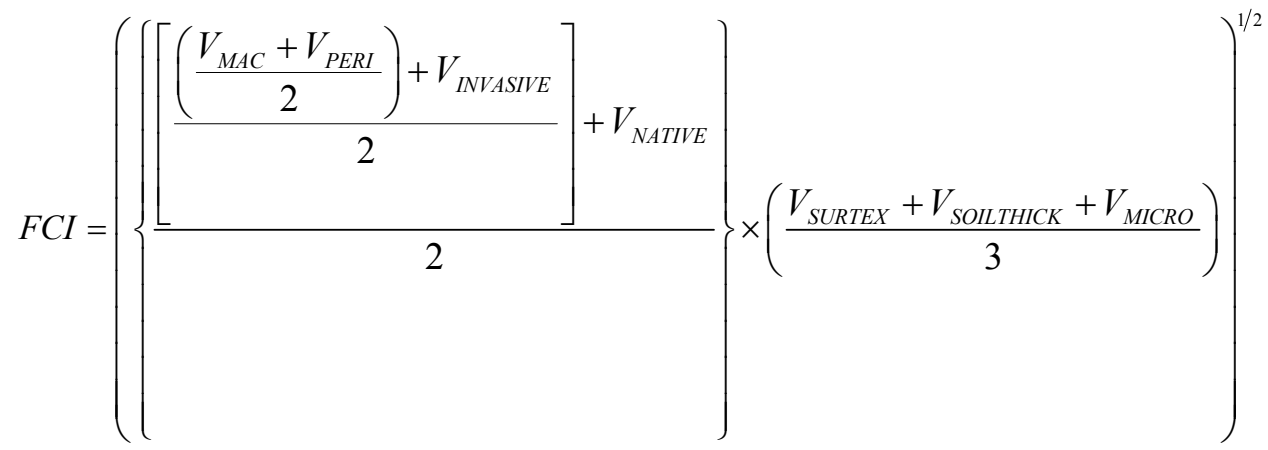

(2) For Marl Flats Everglades wetlands

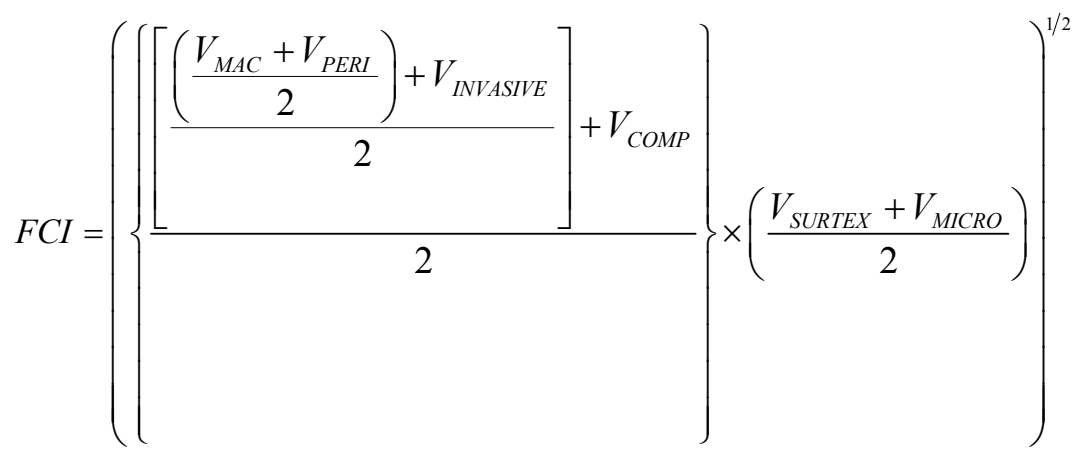


(3) For Organic Flats Everglades wetlands

$$
F C I=\left\{\left[\frac{\left(\frac{V_{\text {MAC }}+V_{\text {INVASIVE }}}{2}\right)+V_{\text {COMP }}}{2}\right] \times\left(\frac{V_{\text {SURTEX }}+V_{\text {MICRO }}}{2}\right)\right\}^{1 / 2}
$$

\section{Function 4: Wildlife Habitat}

a. Definition. Provide Wildlife Habitat is defined as the ability of an Everglades wetland to support the wildlife species that use Everglades wetlands during part of their life cycles. A potential independent, quantitative measure of this function is a similarity index-calculated from species composition and abundance (Odum 1950; Sorenson 1948).

b. Model variables - symbols - measures - units.

(1) Habitat Connections $-V_{C O N N E C T}-$ percent of the wetland tract perimeter connected - unitless.

(2) Interior Core Area $-V_{C O R E}$ - percent of the wetland tract with 300-m buffer - unitless.

(3) Wetland Tract Area $-V_{T R A C T}-$ size of wetland tract - hectares.

(4) Surface Soil Texture - $V_{\text {SURTEX }}$ - U.S. Department of Agriculture textural class or term used in lieu of texture of the surface soil horizon - unitless.

(5) Soil Thickness (Rocky Flats wetlands subclass only) - $V_{\text {SOILTHICK }}-$ total thickness of the soil over limestone rock - centimeters.

(6) Microtopographic Features $-V_{M I C R O}$ - percent of the area with altered microtopographic features - unitless.

(7) Emergent Macrophytic Vegetation Cover $-V_{M A C}$ - percent cover of macrophytic vegetation - unitless.

(8) Periphyton Cover (Rocky and Marl Flats wetlands subclasses only) - $V_{P E R I}-$ percent cover of periphyton - unitless.

(9) Invasive Vegetation Cover - $V_{\text {INVASIVE }}$ - percent cover of invasive vegetation - unitless.

(10) Number of Native Wetland Species (Rocky Flats wetlands subclass only) $-V_{\text {NATIVE }}$ - total number of native wetland species - unitless. 
(11) Plant Species Composition (Marl and Organic Flats wetlands subclasses only) $-V_{C O M P}-$ percent concurrence with dominant species by strata - unitless.

c. Assessment model:

(1) For Rocky Flats Everglades wetlands

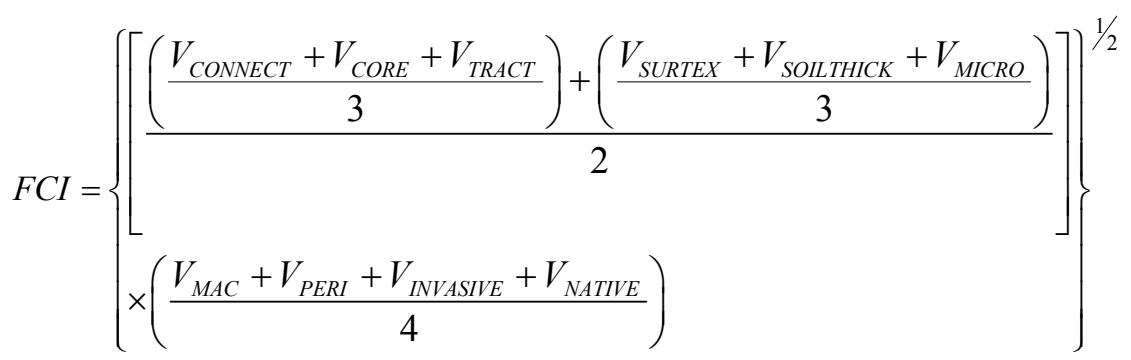

(2) For Marl Flats Everglades wetlands:

$F C I=\left\{\begin{array}{l}{\left[\frac{\left(\frac{\left.V_{\text {CONNECT }}+V_{\text {CORE }}+V_{\text {TRACT }}\right)+\left(\frac{V_{\text {SURTEX }}+V_{\text {MICRO }}}{2}\right)}{2}\right]}{\times\left(\frac{V_{\text {MAC }}+V_{\text {PERI }}+V_{\text {INVASIVE }}+V_{\text {COMP }}}{4}\right)}\right]}\end{array}\right.$

(3) For Organic Flats Everglades wetlands:

$$
F C I=\left\{\begin{array}{l}
{\left[\frac{\left(\frac{\left.V_{\text {CONNECT }}+V_{\text {CORE }}+V_{\text {TRACT }}\right)+\left(\frac{V_{\text {SURTEX }}+V_{\text {MICRO }}}{2}\right)}{2}\right]}{\times\left(\frac{V_{\text {MAC }}+V_{\text {INVASIVE }}+V_{\text {COMP }}}{3}\right)}\right]}
\end{array}\right\}
$$

\section{Summary of Model Variables, Measure/Units, and Methods}

\section{Wetland Tract $\left(V_{T R A C T}\right)$}

Measure/Units: The area of wetland in hectares that is not separated by $50 \mathrm{~m}$ or more of unsuitable habitat from the Wetland Assessment Area (WAA) and of the same regional wetland subclass. 
Method:

(1) Determine the size of the area of wetland of the same regional subclass that is not separated by $50 \mathrm{~m}$ or more of unsuitable habitat from the assessment area using topographic maps, National Wetland Inventory maps (NWI), and/or aerial photography. Examples of unsuitable habitat would include but are not limited to farmland, upland housing developments, industrial parks, open water, and mined areas.

(2) Report the size of the wetland tract in hectares.

(3) Verify during field reconnaissance.

\section{Interior Core Area ( $\left.V_{\text {CORE }}\right)$}

Measure/Units: The percent of the wetland tract with a buffer zone of $300 \mathrm{~m}$ separating it from unsuitable habitat.

Method:

(1) Determine the area of the wetland tract within a buffer of at least $300 \mathrm{~m}$ using topographic maps, NWI maps, and/or aerial photography.

(2) Divide the area of the wetland within the buffer by the total size of the wetland tract and multiply by 100 . The result is the percentage of the wetland tract within the buffer zone.

(3) Report the size of the area within a 300-m buffer as a percentage of the total tract area.

(4) Verify during field reconnaissance.

\section{Habitat Connections $\left(V_{\text {CONNECT }}\right)$}

Measure/Units: Percentage of the perimeter of the wetland tract that is connected to similar or other native habitats.

Method:

(1) Determine the total length of the wetland tract using topographic maps, NWI maps, and/or aerial photography.

(2) Measure the total length of wetland perimeter that is adjacent to suitable habitat.

(3) Divide the length of connected wetland perimeter by the total length of the wetland perimeter.

(4) Multiply by 100 to convert to a percentage. 
(5) Report the percentage of the wetland tract perimeter that is connected to suitable habitat.

(6) Verify during field reconnaissance.

\section{Microtopographic Features ( $\left.V_{\text {MICRO }}\right)$}

Measure/Units: Percent of the wetland that has altered microtopographic features.

Method:

(1) Estimate the percentage of the ground surface that has altered microtopographic features (i.e., bedding, rock plowing, or land leveling) using aerial photography.

(2) If no altered areas exist, assign a value of 1.0.

(3) If areas with altered microtopography exist, determine the percent of the area that has altered microtopography. Using Table B1, assign a subindex score for each alteration found.

(4) Report the percent of the WAA or Partial Wetland Assessment Area (PWAA) with altered microtopography.

\section{Table B1 \\ Microtopographic Features}

\begin{tabular}{|l|l|}
\hline \hline Alteration Category & Variable Subindex \\
\hline \hline
\end{tabular}

\begin{tabular}{|l|l}
\hline Rock plowing & 0.0 \\
\hline Vand & 0.1 \\
\hline
\end{tabular}

\begin{tabular}{|l|l}
\hline Land leveling & 0.1 \\
\hline Bedding & 0.2 \\
\hline
\end{tabular}

\begin{tabular}{|l|l|}
\hline Bedding & 0.1 \\
\hline
\end{tabular}

\begin{tabular}{|c|c} 
Unaltered & 0.2 \\
\hline
\end{tabular}

\section{Cover of Woody Vegetation ( $\left.V_{\text {woody }}\right)$}

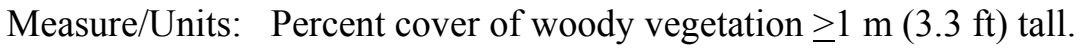

Method:

(1) Visually estimate the percent of the ground surface that is covered by woody vegetation by mentally projecting the leaves and stems to the ground surface.

(2) Average the percent woody cover from all of the plots.

(3) Report woody vegetation cover as a percent. 


\section{Invasive Vegetation Cover ( IINVASIVE)}

Measure/Units: Percent cover of invasive vegetation (Table B2).

Method:

(1) Visually estimate the percent of the ground surface that is covered by invasive vegetation by mentally projecting the leaves and stems to the ground surface.

(2) Average the percent invasive cover from all of the subplots.

(3) Report invasive vegetation cover as a percent.

\section{Number of Native Wetland Species ( $\left.V_{\text {NATIVE }}\right)$}

Measure/Units: The total number of native wetland species in Rocky Flats Everglades.

Method:

(1) Count each native vegetative species that has a Wetland Indicator Status of FAC, FACW, or OBG in each strata (Appendix C). Add the number of native wetland species from each vegetative strata and report the total number of native wetland species. Users do not need to determine the taxonomic classification of each species, but must be able to recognize those species that are not native to Florida and are not typically found in wetlands. Users who do not feel confident in making these identifications should get help with plant identification.

(2) Using Table B3, assign a variable subindex score.

\section{Emergent Macrophytic Vegetation Cover $\left(V_{M A C}\right)$}

Measure/Units: Percent cover of macrophytic vegetation.

Method:

(1) Visually estimate the percent of the ground surface covered by macrophytic vegetation by mentally projecting the leaves and stems to the ground surface.

(2) Average the percent macrophytic vegetation cover from all of the subplots.

(3) Report macrophytic vegetation cover as a percent. 


\begin{tabular}{|c|c|}
\hline \multicolumn{2}{|c|}{$\begin{array}{l}\text { Table B2 } \\
\text { Invasive Vegetation Species }\end{array}$} \\
\hline Scientific Name & Common Name \\
\hline Abrus precatorius & Rosary pea \\
\hline Acacia auriculiformis & Earleaf acacia \\
\hline Adenanthera pavonina & Red sandalwood \\
\hline Agave sisalana & Sisal \\
\hline Albizia julibrissin & Silk tree \\
\hline Albizia lebbeck & Woman's-tongue tree \\
\hline$\overline{\text { Aleurites fordii }}$ & Tung oil tree \\
\hline Alstonia macrophylla & Devil-tree \\
\hline Alternanthera philoxeroides & Alligator weed \\
\hline Antigonon leptopus & Coral vine \\
\hline Ardisia crenata & Coral ardisia \\
\hline Ardisia elliptica $^{1}$ & Shoebutton ardisia \\
\hline Aristolochia littoralis & Calico flower \\
\hline Asparagus densiflorus & Asparagus fern \\
\hline Asystasia gangetica & Ganges primrose \\
\hline Bauhinia variegata & Orchid tree \\
\hline Begonia cucullata & Clubed begonia \\
\hline Bischofia javanica & Bishopwood \\
\hline Broussonetia papyrifera & Paper mulberry \\
\hline Callisia fragrans & Basketplant \\
\hline Calophyllum antillanum & Santa maria \\
\hline Casuarina cunninghamiana & River sheoak \\
\hline Casuarina equisetifolia $^{1}$ & Australian pine \\
\hline Casuarina glauca & Gray sheoak \\
\hline Cestrum diurnum & Day jasmine \\
\hline Cinnamomum camphora & Camphor tree \\
\hline Colocasia esculenta & Wild taro \\
\hline Colubrina asiatica & Asian snakewood \\
\hline Cordia dichotoma & Fragrant manjack \\
\hline Cryptostegia madagascariensis & Rubber vine \\
\hline Cupaniopsis anacardioides & Carrotwood \\
\hline Cyperus involucratus & Umbrella flatsedge \\
\hline Cyperus prolifer & Dwarf papyrus \\
\hline Dalbergia sissoo & Indian rosewood \\
\hline Daphne laureola & Spurge laurel \\
\hline Dioscorea alata & Winged yam \\
\hline Dioscorea bulbifera & Air potato \\
\hline Eichhornia crassipes & Water hyacinth \\
\hline Elaeagnus pungens & Thorny elaeagnus \\
\hline Epipremnum pinnatum & Pothos \\
\hline Eugenia uniflora & Surinam cherry \\
\hline Ficus altissima & False banyan \\
\hline Ficus microcarpa & Laurel fig \\
\hline Flacourtia indica & Governor's plum \\
\hline$\overline{\text { Flueggea virosa }}$ & Chinese waterberry \\
\hline Hibiscus tiliaceus & Sea hibiscus \\
\hline Hiptage benghalensis & Hiptage \\
\hline Hydrilla verticillata & Hydrilla \\
\hline Hygrophila polysperma & Indian swampweed \\
\hline Hymenachne amplexicaulis & West Indian marsh grass \\
\hline Imperata cylindrica & Cogon grass \\
\hline Ipomoea aquatica & Water spinach \\
\hline Jasminum dichotomum & Gold Coast jasmine \\
\hline Jasminum fluminense & Brazilian jasmine \\
\hline Jasminum sambac & Arabian jasmine \\
\hline Koelreuteria elegans & Golden rain tree \\
\hline
\end{tabular}

(Sheet 1 of 3 ) 


\begin{tabular}{|c|c|c|}
\hline \multicolumn{2}{|l|}{ Table B2 (Continued) } & \\
\hline Scientific Name & Common Name & \\
\hline Lantana camara & Lantana & \\
\hline Leucaena leucocephala & Lead tree & \\
\hline Ligustrum lucidum & Glossy privet & \\
\hline Ligustrum sinense & Chinese privet & \\
\hline Limnophila sessiliflora & Asian marshweed & \\
\hline Lonicera japonica & Chinese honeysuckle & \\
\hline Lygodium japonicum & Japanese climbing fern & \\
\hline Lygodium microphyllum & Old world climbing fern & \\
\hline Macfadyena unguis-cati & Claw vine & \\
\hline Manilkara zapota & Sapodilla & \\
\hline Melaleuca quinquenervia ${ }^{1}$ & Melaleuca & \\
\hline Melia azedarach & Chinaberry tree & \\
\hline Melinis minutiflora & Molasses grass & \\
\hline Melinis repens & Natal grass & \\
\hline Merremia tuberosa & Wood rose & \\
\hline Mimosa pigra & Catclaw mimosa & \\
\hline Murraya paniculata & Orange-jessamine & \\
\hline Myriophyllum spicatum & Eurasian watermilfoil & \\
\hline Nandina domestica & Heavenly bamboo & \\
\hline Nephrolepis cordifolia & Boston fern & \\
\hline Nephrolepis multiflora & Asian swordfern & \\
\hline Neyraudia reynaudiana & Silk reed & \\
\hline Ochrosia elliptica & Elliptic yellowwood & \\
\hline Oeceoclades maculata & Ground orchid & \\
\hline Paederia cruddasiana & Onion vine & \\
\hline Paederia foetida & Skunk vine & \\
\hline Panicum repens & Torpedo grass & \\
\hline Passiflora biflora & Twin-flowered passionvine & \\
\hline Passiflora foetida & Stinking passionflower & \\
\hline Pennisetum purpureum $^{1}$ & Elephant grass & \\
\hline Pennisetum setaceum & Crimson fountaingrass & \\
\hline Phoenix reclinata & Reclining date palm & \\
\hline Phyllostachys aurea & Golden bamboo & \\
\hline Psidium cattleianum & Strawberry guava & \\
\hline$P^{P}$ sidium guajava ${ }^{1}$ & Guava & \\
\hline Pteris vittata & Ladder brake & \\
\hline Ptychosperma elegans & Solitary palm & \\
\hline Pueraria montana var. lobata & Kudzu & \\
\hline Rhodomyrtus tomentosus & Rose myrtle & \\
\hline Rhynchelytrum repens & Natal grass & \\
\hline Ricinus communis & Castor bean & \\
\hline Ruellia brittoniana & Mexican petunia & \\
\hline Sansevieria hyacinthoides & Bowstring hemp & \\
\hline Sapium sebiferum & Chinese tallow tree & \\
\hline Scaevola sericea & Beach naupaka & \\
\hline Schefflera actinophylla & Umbrella tree & \\
\hline Schinus terebinthifolius $^{1}$ & Brazilian pepper-tree & \\
\hline Senna pendula var. glabrata & Climbing cassia & \\
\hline Sesbania punicea & Rattlebox & \\
\hline Solanum diphyllum & Twinleaf nightshade & \\
\hline Solanum jamaicense & Jamaica nightshade & \\
\hline Solanum tampicense & Aquatic soda apple & \\
\hline Solanum torvum & Turkeyberry & \\
\hline Solanum viarum & Tropical soda apple & \\
\hline Sphagneticola trilobata & Bay Biscayne creeping-oxeye & \\
\hline Syngonium podophyllum & Arrowhead vine & \\
\hline Syzygium cumini & Java plum & \\
\hline Syzygium jambos & Rose-apple & \\
\hline & & (Sheet 2 of 3 ) \\
\hline
\end{tabular}




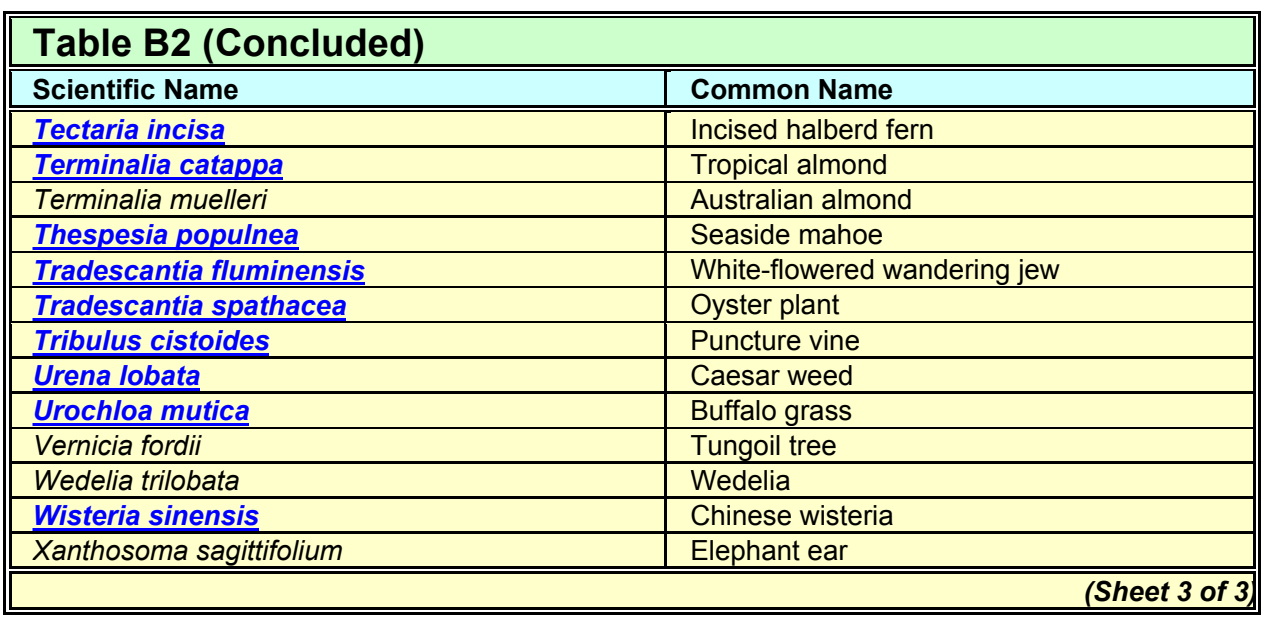

\begin{tabular}{|l|l||}
\hline $\begin{array}{l}\text { Table B3 } \\
\text { Number of Native Wetland Species in Rocky Flats Everglades } \\
\text { Wetlands }\end{array}$ \\
\hline \hline Number of Species & Subindex Score \\
\hline $\mathbf{2 0}$ & 1.0 \\
\hline \hline 19 & 0.95 \\
\hline 18 & 0.9 \\
\hline 17 & 0.85 \\
\hline 16 & 0.8 \\
\hline 15 & 0.75 \\
\hline 14 & 0.7 \\
\hline 13 & 0.65 \\
\hline 12 & 0.6 \\
\hline 11 & 0.55 \\
\hline 10 & 0.5 \\
\hline 9 & 0.45 \\
\hline 8 & 0.4 \\
\hline 7 & 0.35 \\
\hline 6 & 0.3 \\
\hline 5 & 0.25 \\
\hline 4 & 0.20 \\
\hline 3 & 0.15 \\
\hline 2 & 0.1 \\
\hline 1 & 0.05 \\
\hline 0 & 0 \\
\hline
\end{tabular}

\section{Periphyton Cover $\left(V_{P E R I}\right)$}

Measure/Units: Percent cover of periphyton.

Method:

(1) Visually estimate the percent of the ground surface that is covered by periphyton.

(2) Average the percent cover of periphyton from all of the subplots.

(3) Report periphyton cover as a percent. 


\section{Surface Soil Texture ( $\left.V_{\text {SURTEX }}\right)$}

Measure/Units: Soil texture of surface horizon or layer of the WAA or Partial Wetland Assessment Area (PWAA) as a percent of the WAA or PWAA.

Method:

(1) Estimate the texture class of the surface horizon using the feel method in or adjacent to each of the three $1-\mathrm{m}^{2}\left(3.3-\mathrm{ft}^{2}\right)$ subplots

(2) Using Table B4 or Table B5, assign a score for each texture class found.

(3) Average the scores from each of the subplots.

(4) Assign a subindex score based on the average score from the subplots.

\begin{tabular}{|c|c|}
\hline \multicolumn{2}{|c|}{$\begin{array}{l}\text { Table B4 } \\
\text { Soil Surface Texture for Rocky and Marl Flats Everglades } \\
\text { Wetlands }\end{array}$} \\
\hline Soil Texture & Score \\
\hline Marl $^{1}$ & 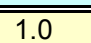 \\
\hline Muck $^{1}$ & 0.8 \\
\hline Silt & 0.9 \\
\hline Silt loam & 0.9 \\
\hline Loam & 0.5 \\
\hline Gravelly silt loam $(15 \%$ to $<35 \%$ gravel) & 0.4 \\
\hline Gravelly silt $(15 \%$ to $<35 \%$ gravel $)$ & 0.4 \\
\hline Very gravelly silt loam ( $35 \%$ to $<60 \%$ gravel) & 0.3 \\
\hline Very gravelly silt ( $35 \%$ to $<60 \%$ gravel) & 0.3 \\
\hline Sandy loam & 0.2 \\
\hline Clay & 0.2 \\
\hline Sand & 0.2 \\
\hline Loamy sand & 0.2 \\
\hline Extremely gravelly silt loam ( $60 \%$ to $<90 \%$ gravel) & 0.2 \\
\hline Extremely gravelly silt $(60 \%$ to $<90 \%$ gravel) & 0.2 \\
\hline Gravel $^{1}(\geq 90 \%$ gravel) & 0.1 \\
\hline Rock & 0.0 \\
\hline Pavement ${ }^{1}$ & 0.0 \\
\hline
\end{tabular}

\section{Soil Thickness ( $\left.V_{\text {sollthIck }}\right)$}

Measure/Units: Average soil thickness over limestone bedrock in centimeters.

Method:

(1) Measure the total marl soil depth to limestone outside of solution holes in each $1-\mathrm{m}^{2}\left(3.3-\mathrm{ft}^{2}\right)$ subplot in Rocky Flats Everglades.

(2) Average the thickness from all of the subplots. 


\begin{tabular}{|c|c|}
\hline \multicolumn{2}{|c|}{$\begin{array}{l}\text { Table B5 } \\
\text { Soil Surface Texture for Organic Flats Everglades Wetland }\end{array}$} \\
\hline Soil texture & Score \\
\hline Muck $^{1}$ & 1.0 \\
\hline Marl $^{1}$ & 0.8 \\
\hline Silt & 0.9 \\
\hline Silt loam & 0.9 \\
\hline Loam & 0.5 \\
\hline Gravelly silt loam ( $15 \%$ to $<35 \%$ gravel) & 0.4 \\
\hline Gravelly silt $(15 \%$ to $<35 \%$ gravel) & 0.4 \\
\hline Very gravelly silt loam $(35 \%$ to $<60 \%$ gravel) & 0.3 \\
\hline Very gravelly silt ( $35 \%$ to $<60 \%$ gravel) & 0.3 \\
\hline Sandy loam & 0.2 \\
\hline Clay & 0.2 \\
\hline Sand & 0.2 \\
\hline Loamy sand & 0.2 \\
\hline Extremely gravelly silt loam $(60 \%$ to $<90 \%$ gravel) & 0.2 \\
\hline Extremely gravelly silt $(60 \%$ to $<90 \%$ gravel) & 0.2 \\
\hline Gravel $^{1}(\geq 90 \%$ gravel) & 0.1 \\
\hline Rock & 0.0 \\
\hline Pavement ${ }^{1}$ & 0.0 \\
\hline
\end{tabular}

(3) Report the soil thickness in centimeters.

(4) Assign a subindex score based on the average soil thickness from the subplots.

\section{Plant Species Composition ( $\left.V_{\text {сом⿰ }}\right)$}

Measure/Units: Percent concurrence with the dominant species in all vegetation strata.

Method:

(1) Identify the dominant species in the canopy, understory vegetation, and ground vegetation strata using the 50/20 rule. ${ }^{1}$ Use percent cover for all vegetation strata. To apply the 50/20 rule, rank species from each strata in descending order of abundance. Identify dominants by summing the normalized abundance measure beginning with the most abundant species in descending order until 50 percent is exceeded. Additional species with $\geq 20$ percent normalized abundance are also considered as dominants. Accurate species identification is critical for determining the dominant species in each plot. Sampling during the dormant season may require a high degree of proficiency in identifying tree bark or dead plant parts. Users who do not feel confident in identifying plant species in all strata should get help with plant identification.

\footnotetext{
${ }^{1}$ Memorandum, 6 March 1992, Office, Chief of Engineers, Clarification of Use of the 1987 Delineation Manual.
} 
(2) For each vegetation strata, calculate percent concurrence by comparing the list of dominant plant species from each strata to the list of dominant species for each strata in reference standard wetlands in Table B6 or B7. For example, if all the dominants from the area being assessed occur on the list of dominants from reference standard wetlands, then there is 100 percent concurrence. If three of the five dominant species from the area being assessed occur on the list, then there is 60 percent concurrence.

(3) Average the percent concurrence from all three strata.

(4) Report percent concurrence with the dominant species in all vegetation strata.

\begin{tabular}{|c|c|}
\hline \multicolumn{2}{|c|}{$\begin{array}{l}\text { Table B6 } \\
\text { Dominant Plant Species, Marl Flats }\end{array}$} \\
\hline Scientific Name & Common Name \\
\hline Andropogon glomeratus & Bushy bluestem \\
\hline Bacopa caroliniana & Blue waterhyssop \\
\hline Cladium jamaicense & Saw grass \\
\hline Crinum americanun & Seven sisters \\
\hline Eragrostis refracta & Coastal lovegrass \\
\hline Hyptis alata & Clustered bushmint \\
\hline Mikania scandens & Climbing hempweed \\
\hline Muhlenbergia capillaris & Muhly grass \\
\hline Panicum tenerum & Bluejoint panic grass \\
\hline Paspalum monastachyum & Gulfdune paspalum \\
\hline Pluchea rosea & Rosy camphorweed \\
\hline Proserpinaca palustris & Marsh mermaid weed \\
\hline Rhynchospora divergens & Spreading beaksedge \\
\hline Rhynchospora microcarpa & Southern beaksedge \\
\hline Rhynchospora tracyi & Tracy's beaksedge \\
\hline Schizachyrium rhizomatum & Florida little bluestem \\
\hline Spartina alterniflora & Smooth cordgrass \\
\hline Utricularia purpurea & Eastern purple bladderwort \\
\hline
\end{tabular}

\section{Table B7}

\section{Dominant Plant Species, Organic Flats}

\begin{tabular}{|l|l|}
\hline Scientific Name & Common Name \\
\hline Bacopa caroliniana & Blue waterhyssop \\
\hline Cladium jamaicense & Saw grass \\
\hline Eleocharis cellulosa & Coastal spikerush \\
\hline Eleocharis elongata & Slim spikerush \\
\hline Panicum hemitomon & Maiden cane \\
\hline Peltandra virginica & Green arrow arum \\
\hline Polygonum hydropiperoides & Swamp smartweed \\
\hline Pontederia cordata & Pickerelweed \\
\hline Sagittaria lanceolata & Bulltongue arrowhead \\
\hline Utricularia foliosa & Leafy bladderwort \\
\hline Utricularia purpurea & Eastern purple bladderwort \\
\hline
\end{tabular}




\section{Summary of Variables by Function}

This section provides a listing of the model variables by function.

\begin{tabular}{||l|l||}
\hline \multicolumn{2}{|l|}{ Rocky Flats Everglades Wetlands } \\
\hline \hline Variables & Function \\
\hline \hline 1. Wetland Tract $\left(V_{\text {TRACT }}\right)$ & Wildlife habitat \\
\hline 2. Interior Core Area $\left(V_{\text {CORE }}\right)$ & Wildlife habitat \\
\hline 3. Habitat Connections $\left(V_{\text {CONNECT }}\right)$ & Wildlife habitat \\
\hline 4. Microtopographic Features $\left(V_{\text {MICRO }}\right)$ & $\begin{array}{l}\text { Surface and subsurface water storage } \\
\text { Cycle nutrients } \\
\text { Characteristic plant community } \\
\text { Wildlife habitat }\end{array}$ \\
\hline 5. Cover of Woody Vegetation $\left(V_{\text {WOODY }}\right)$ & Surface and subsurface water storage \\
\hline 6. Invasive Vegetation Cover $\left(V_{\text {INVASIVE }}\right)$ & $\begin{array}{l}\text { Cycle nutrients } \\
\text { Characteristic plant community } \\
\text { Wildlife habitat }\end{array}$ \\
\hline 7. Number of Native Wetland Species $\left(V_{\text {NATIVE }}\right)$ & $\begin{array}{l}\text { Characteristic plant community } \\
\text { Wildlife habitat }\end{array}$ \\
\hline 8. Emergent Macrophytic Vegetation $\left(V_{\text {MAC }}\right)$ & $\begin{array}{l}\text { Characteristic plant community } \\
\text { Wildlife habitat }\end{array}$ \\
\hline 9. Periphyton $\left(V_{P E R I}\right)$ & $\begin{array}{l}\text { Surface and subsurface water storage } \\
\text { Characteristic plant community } \\
\text { Wildlife habitat }\end{array}$ \\
\hline 10. Surface Soil Texture $\left(V_{S U R T E X}\right)$ & $\begin{array}{l}\text { Surface and subsurface water storage } \\
\text { Cycle nutrients } \\
\text { Characteristic plant community } \\
\text { Wildlife habitat }\end{array}$ \\
\hline 11. Soil Thickness $\left(V_{\text {SOILTHICK }}\right)$ & $\begin{array}{l}\text { Surface and subsurface water storage } \\
\text { Characteristic plant community } \\
\text { Wildlife habitat }\end{array}$ \\
\hline \hline & $\begin{array}{l} \\
\end{array}$ \\
\hline
\end{tabular}

\begin{tabular}{||l|l||}
\hline \multicolumn{2}{|l|}{ Marl Flats Everglades Wetlands } \\
\hline \hline Variables & Function \\
\hline \hline 1. Wetland Tract $\left(V_{\text {TRACT }}\right)$ & Wildlife habitat \\
\hline 2. Interior Core Area $\left(V_{\text {CORE }}\right)$ & Wildlife habitat \\
\hline 3. Habitat Connections $\left(V_{\text {CONNECT }}\right)$ & Wildlife habitat \\
\hline 4. Microtopographic Features $\left(V_{\text {MICRO }}\right)$ & $\begin{array}{l}\text { Surface and subsurface water storage } \\
\text { Cycle nutrients } \\
\text { Characteristic plant community } \\
\text { Wildlife habitat }\end{array}$ \\
\hline 5. Cover Of Woody Vegetation $\left(V_{\text {WOODY }}\right)$ & Surface and subsurface water storage \\
\hline 6. Invasive Vegetation Cover $\left(V_{\text {INVASIVE }}\right)$ & $\begin{array}{l}\text { Cycle nutrients } \\
\text { Characteristic plant community } \\
\text { Wildlife habitat }\end{array}$ \\
\hline 8. Emergent Macrophytic Vegetation $\left(V_{\text {MAC }}\right)$ & $\begin{array}{l}\text { Characteristic plant community } \\
\text { Wildlife habitat }\end{array}$ \\
\hline 9. Periphyton ( $\left.V_{P E R I}\right)$ & $\begin{array}{l}\text { Surface and subsurface water storage } \\
\text { Characteristic plant community } \\
\text { Wildlife habitat }\end{array}$ \\
\hline 10. Surface Soil Texture $\left(V_{\text {SURTEX }}\right)$ & $\begin{array}{l}\text { Surface and subsurface water storage } \\
\text { Cycle nutrients } \\
\text { Characteristic plant community } \\
\text { Wildlife habitat }\end{array}$ \\
\hline 12. Plant Species Composition $\left(V_{\text {COMP }}\right)$ & $\begin{array}{l}\text { Characteristic plant community } \\
\text { Wildlife habitat }\end{array}$ \\
\hline
\end{tabular}




\begin{tabular}{||l|l||}
\hline \multicolumn{2}{||l||}{ Organic Flats Everglades Wetlands } \\
\hline \hline Variables & Function \\
\hline \hline 1. Wetland Tract $\left(V_{\text {TRACT }}\right)$ & Wildlife habitat \\
\hline 2. Interior Core Area $\left(V_{\text {CORE }}\right)$ & Wildlife habitat \\
\hline 3. Habitat Connections $\left(V_{\text {CONNECT }}\right)$ & Wildlife habitat \\
\hline 4. Microtopographic Features $\left(V_{\text {MICRO }}\right)$ & $\begin{array}{l}\text { Surface and subsurface water storage } \\
\text { Cycle nutrients } \\
\text { Characteristic plant community } \\
\text { Wildlife habitat }\end{array}$ \\
\hline 5. Cover of Woody Vegetation $\left(V_{\text {WOODY }}\right)$ & Surface and subsurface water storage \\
\hline 6. Invasive Vegetation Cover $\left(V_{\text {INVASIVE }}\right)$ & $\begin{array}{l}\text { Cycle nutrients } \\
\text { Characteristic plant community } \\
\text { Wildlife habitat }\end{array}$ \\
\hline 8. Emergent Macrophytic Vegetation $\left(V_{\text {MAC }}\right)$ & $\begin{array}{l}\text { Characteristic plant community } \\
\text { Wildlife habitat }\end{array}$ \\
\hline 10. Surface Soil Texture $\left(V_{\text {SURTEX }}\right)$ & $\begin{array}{l}\text { Surface and subsurface water storage } \\
\text { Cycle nutrients } \\
\text { Characteristic plant community } \\
\text { Wildlife habitat }\end{array}$ \\
\hline 12. Plant Species Composition $\left(V_{\text {COMP }}\right)$ & $\begin{array}{l}\text { Characteristic plant community } \\
\text { Wildlife habitat }\end{array}$ \\
\hline \hline
\end{tabular}




\section{Summary of Graphs for Transforming Measures to Subindices}

This section summarizes of the graphical transformation of variable measures to variable subindices.
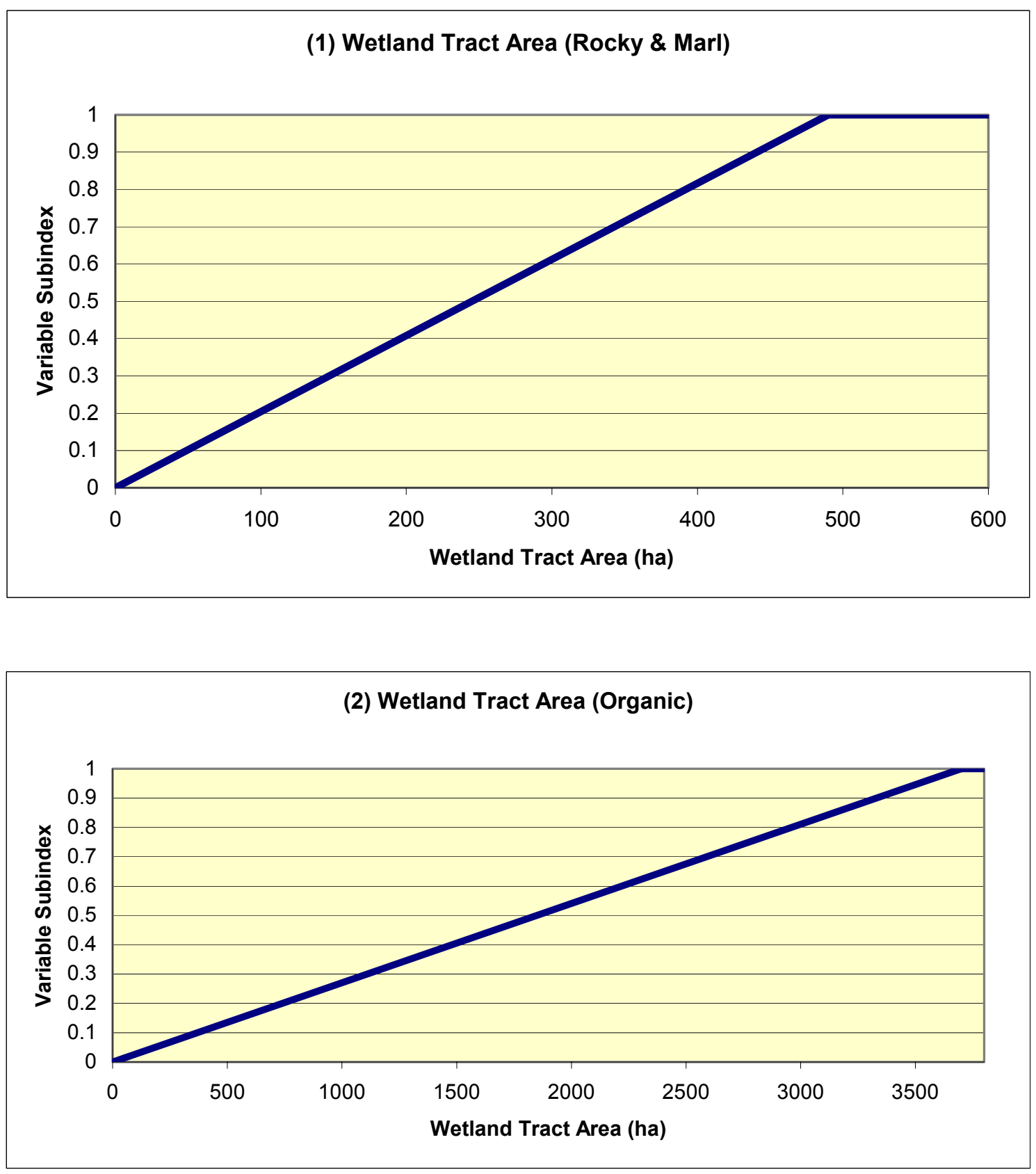

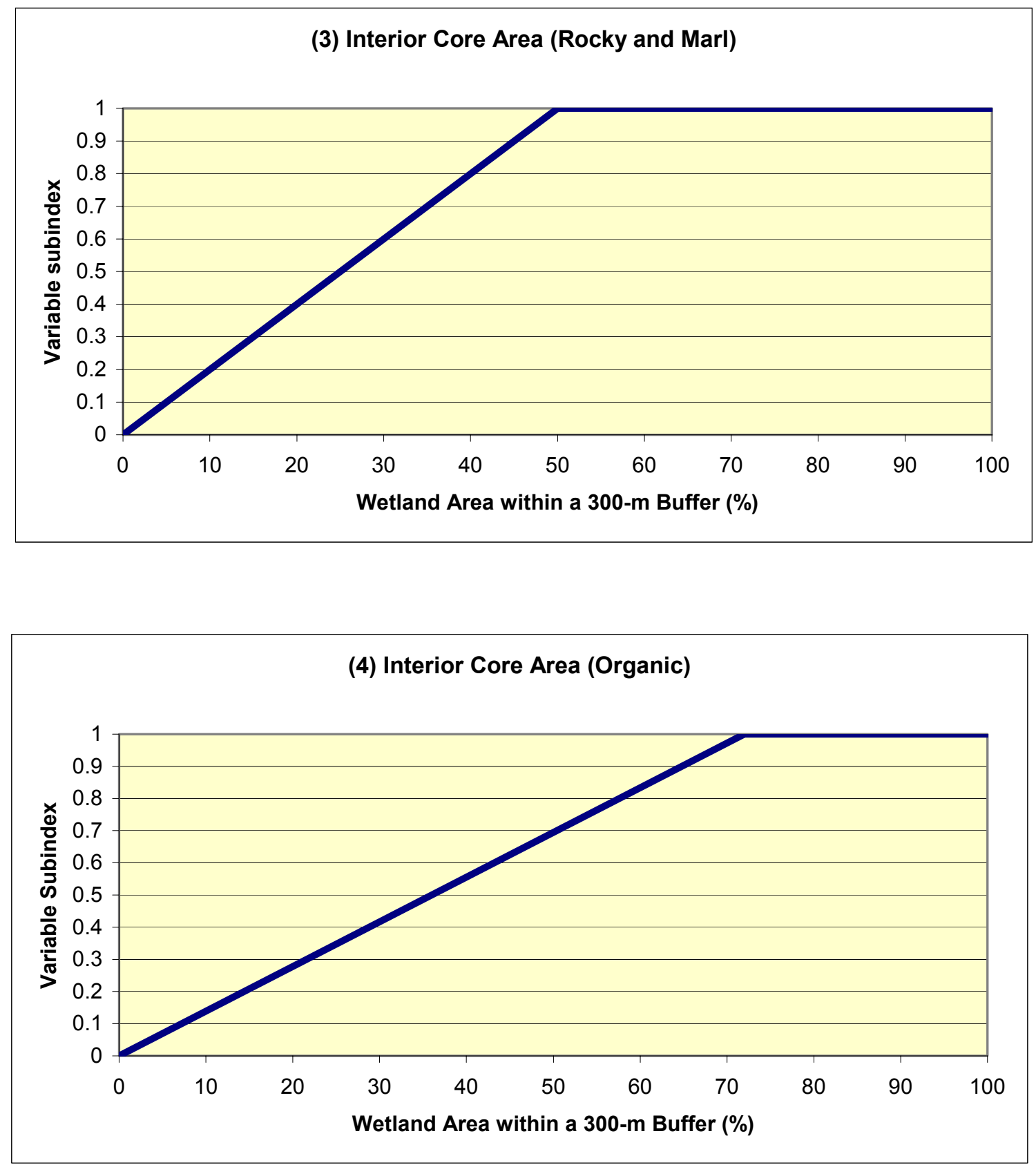

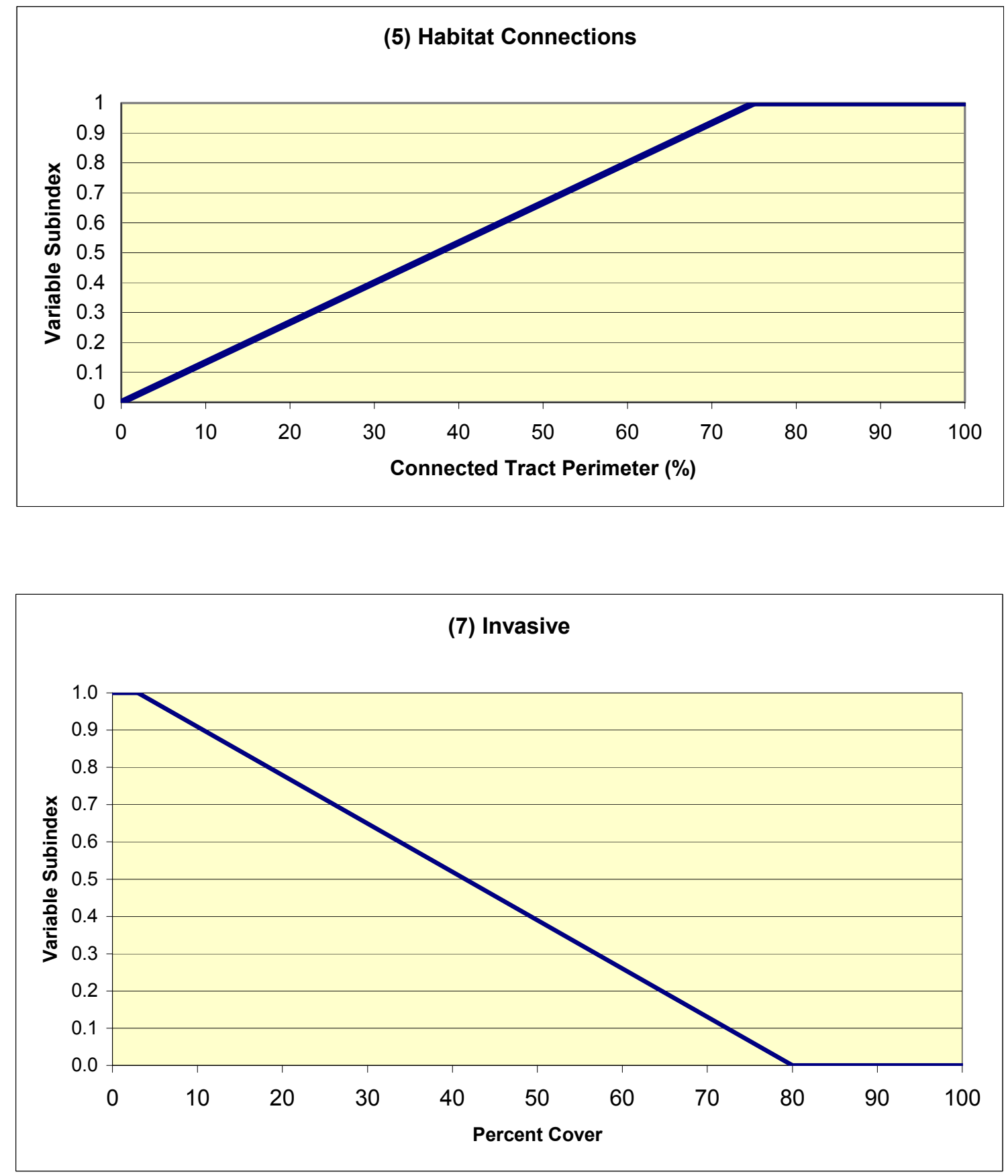

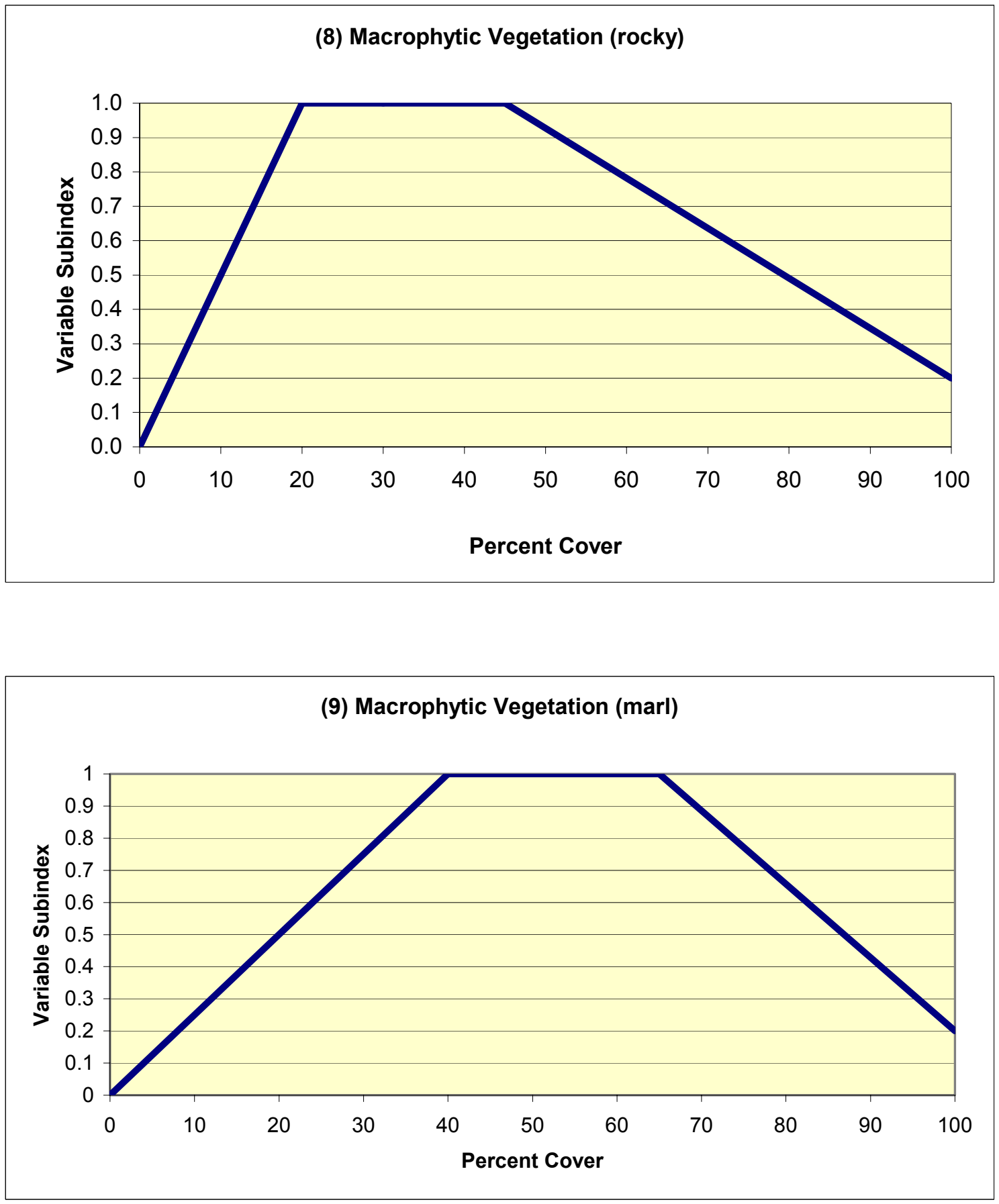

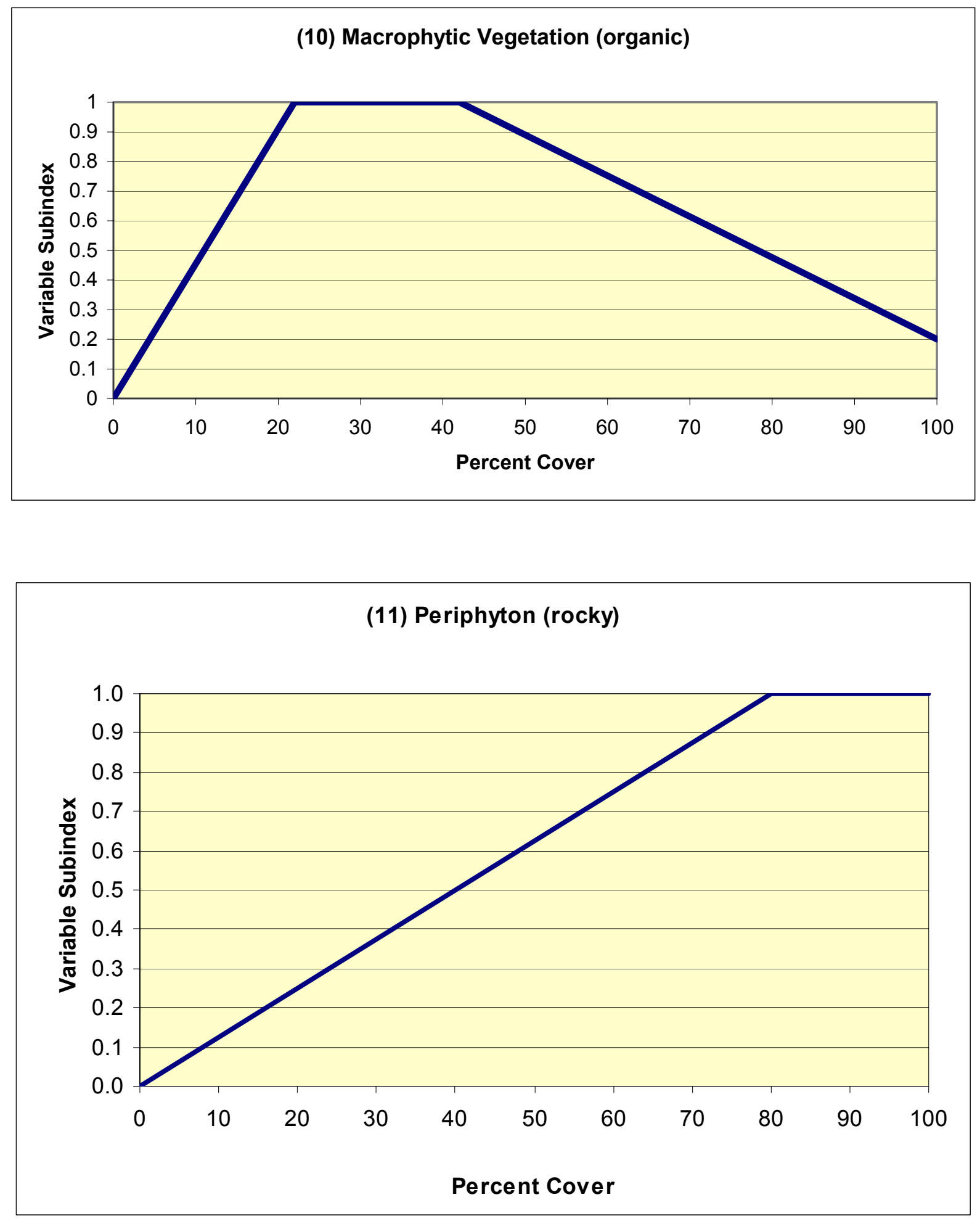

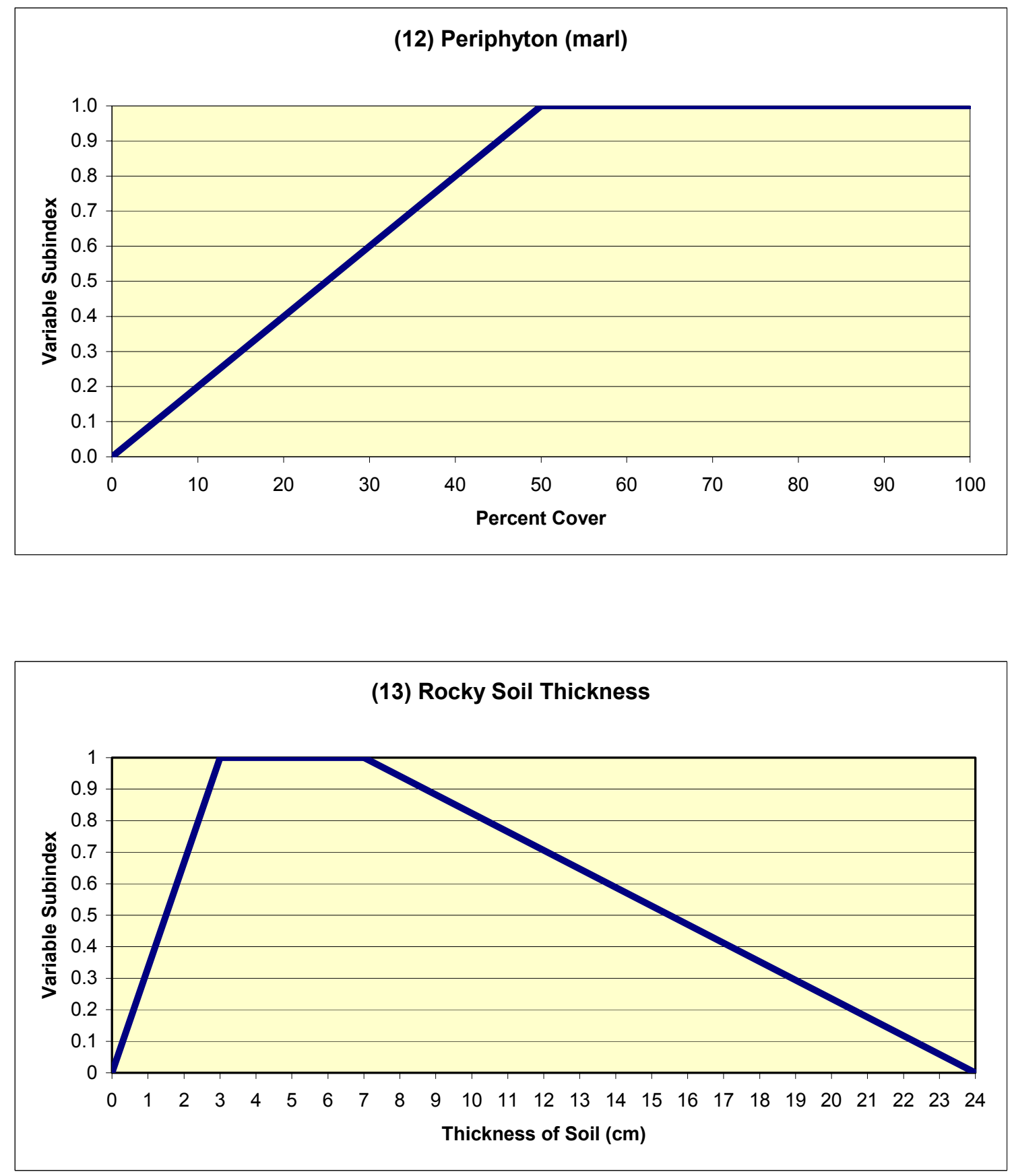

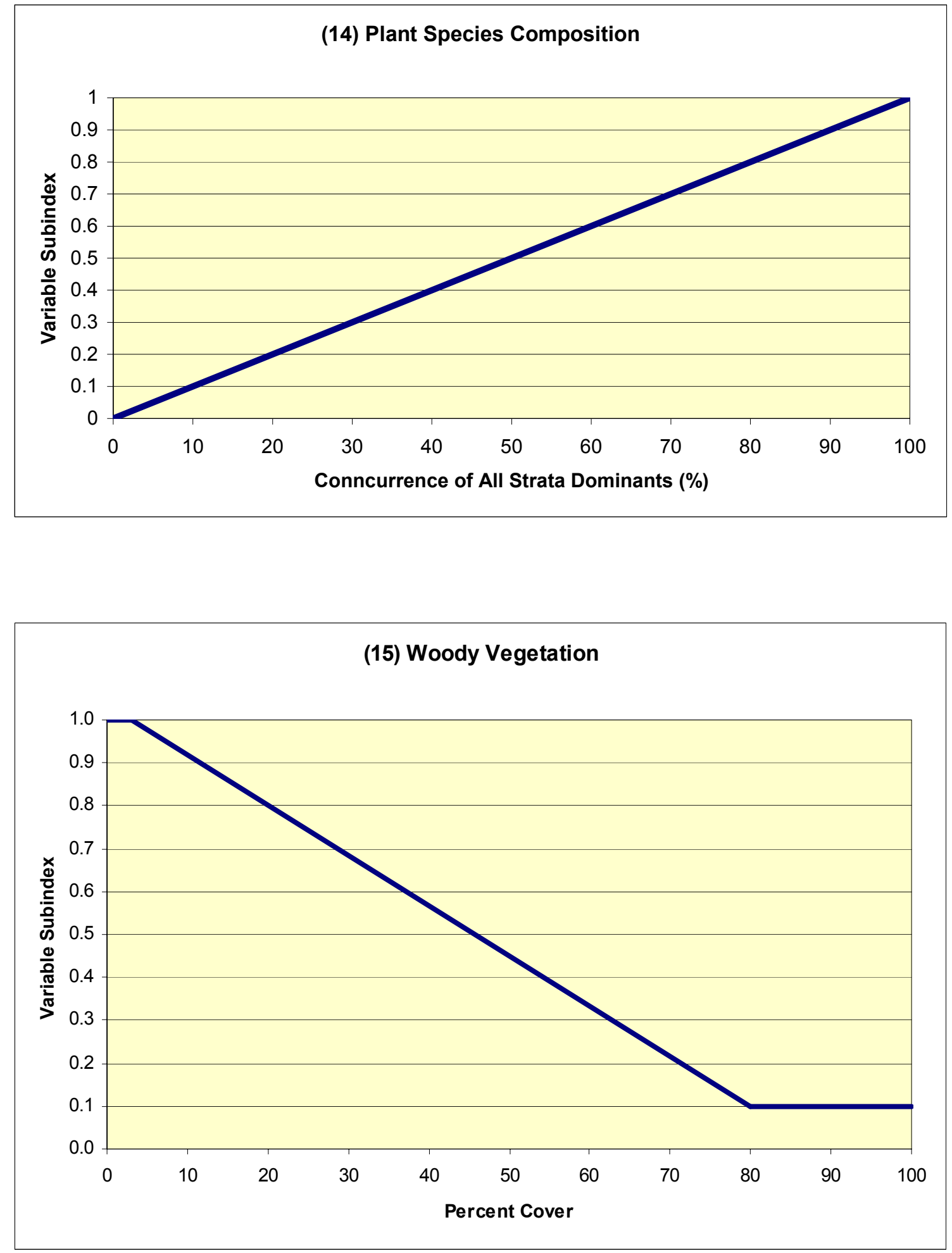


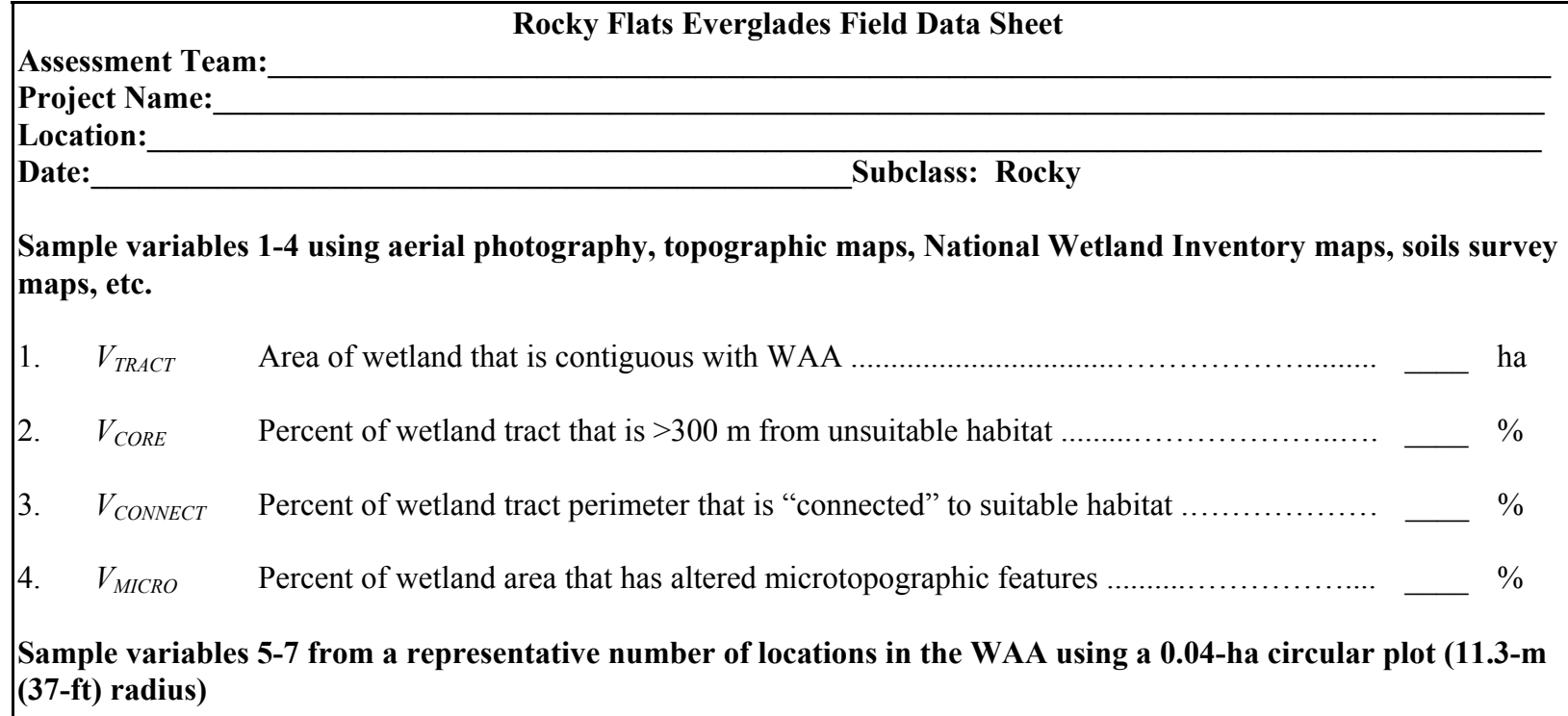

Sample variables 1-4 using aerial photography, topographic maps, National Wetland Inventory maps, soils survey maps, etc.

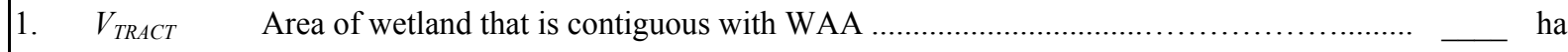

2. $V_{\text {CORE }} \quad$ Percent of wetland tract that is $>300 \mathrm{~m}$ from unsuitable habitat ...........................

3. $V_{\text {CONNECT }}$ Percent of wetland tract perimeter that is "connected" to suitable habitat ................

4. $V_{\text {MICRO }} \quad$ Percent of wetland area that has altered microtopographic features ........................

Sample variables 5-7 from a representative number of locations in the WAA using a 0.04-ha circular plot (11.3-m (37-ft) radius)

5. $V_{W O O D Y}$ Percent cover of woody vegetation $\geq 1 \mathrm{~m}(3.3 \mathrm{ft})$ in height (average of 0.04 -ha values on next line)

Average of 0.04-ha plots sampled: $\%$

6. $V_{\text {INVASIVE }}$ Percent cover of invasive vegetation from all strata (average of 0.04-ha values on next line)...

Average of 0.04-ha plots sampled: $\%$

7. $V_{\text {NATIVE }}$ The total number of native wetland species in Rocky Flats Everglades wetlands ..... \#

Sample variables 8-11 in three (3) 1- $\mathrm{m}^{2}$ subplots placed in representative locations of each quadrant of the 0.04-ha plot

8. $V_{M A C}$

Percent cover of emergent macrophytic vegetation (average of 0.04-ha values on next line)... Average of 0.04-ha plots sampled:

$\begin{array}{rrrr}1 & \% 2 & \% 3 & \% \\ 4 & \% 5 & \% 6 & \% \\ 7 & \% 8 & \% 9 & \%\end{array}$

9. $\quad V_{\text {PERI }}$

Percent cover of periphyton (average of 0 Average of 0.04-ha plots sampled:

\begin{tabular}{|c|c|c|c|}
\hline 1 & $\% 2$ & $\% 3$ & $\%$ \\
\hline 4 & $\% 5$ & $\% 6$ & $\%$ \\
\hline 7 & $\% 8$ & $\% 9$ & $\%$ \\
\hline
\end{tabular}

10. $V_{\text {SURTEX }}$

Soil texture of surface horizon or layer of the WAA as a percent (average of 0.04-ha values on next line)......

Average of 0.04-ha plots sampled:

$\begin{array}{rrrr}1 & \% 2 & \% 3 & \% \\ 7 & \% 5 & \% & 6\end{array} \%$

11. VSOLTHICK Average soil thickness over limestone bedrock in centimeters (average of 0.04-ha values on next line)

$\begin{array}{llrrr}\text { Average of } 0.04 \text {-ha plots sampled: } & 1 & \% 2 & \% 3 & \% \\ & 4 & \% 5 & \% & \% \\ 7 & \% 8 & \% 9 & \%\end{array}$

Figure B1. Field Data Sheet for rocky Flats Everglades Wetlands 


Assessment Team:
Project Name:
Location:
Date: $\quad$ Marl Flats Everglades Field Data Sheet
$\begin{aligned} & \text { Sample variables } 1-4 \text { using aerial photography, topographic maps, National Wetland Inventory maps, soils survey } \\ & \text { maps, etc. }\end{aligned}$
maps, etc.

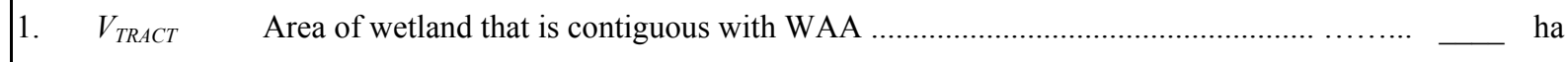

2. $V_{\text {CORE }} \quad$ Percent of wetland tract that is $>300 \mathrm{~m}$ from unsuitable habitat ...................................

3. $V_{\text {CONNECT }}$ Percent of wetland tract perimeter that is "connected" to suitable habitat ................... _

4. $\quad V_{\text {MICRO }} \quad$ Percent of wetland area that has altered microtopographic features ............................

Sample variables $5 \& 6$ from a representative number of locations in the WAA using a 0.04-ha circular plot (11.3-m (37-ft) radius)

5. $V_{W O O D Y}$ Percent cover of woody vegetation $\geq 1 \mathrm{~m}(3.3 \mathrm{ft})$ in height (average of 0.04 -ha values on
6. $V_{\text {INVASIVE }}$ Percent cover of invasive vegetation from all strata (average of 0.04-ha values on next line)...
Average of 0.04-ha plots sampled: $\%$

Sample variables 8-12 in three (3) 1-m² subplots placed in representative locations of each quadrant of the 0.04-ha plot

8. $\quad V_{M A C}$

Percent cover of emergent macrophytic vegetation (average of 0.04-ha values on next line)...

Average of 0.04 -ha plots sampled:

$\begin{array}{crr}1 & \% 2 & \% 3\end{array}$

9. $V_{\text {PERI }}$

Percent cover of periphyton (average of 0.04 -ha values on next line). Average of 0.04-ha plots sampled:

\begin{tabular}{|c|c|c|}
\hline 1 & $\% 2$ & $\% 3$ \\
\hline 4 & $\% 5$ & $\% 6$ \\
\hline 7 & $\% 8$ & $\% 9$ \\
\hline
\end{tabular}

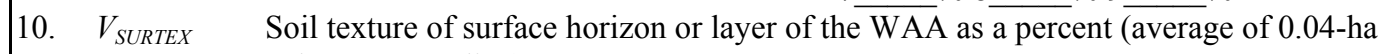
values on next line).

\begin{tabular}{|c|c|c|c|}
\hline \multirow{3}{*}{ Average of 0.04 -ha plots sampled: } & 1 & $\% 2$ & $\% 3$ \\
\hline & 4 & $\% 5$ & $\% 6$ \\
\hline & 7 & $\% 8$ & $\% 9$ \\
\hline
\end{tabular}

12. $V_{\text {СОМP }}$ Concurrence with dominants (average of $0.0 \overline{4-h a}$ values on next line).

Figure B2. Field Data Sheet for Marl Flats Everglades Wetlands 


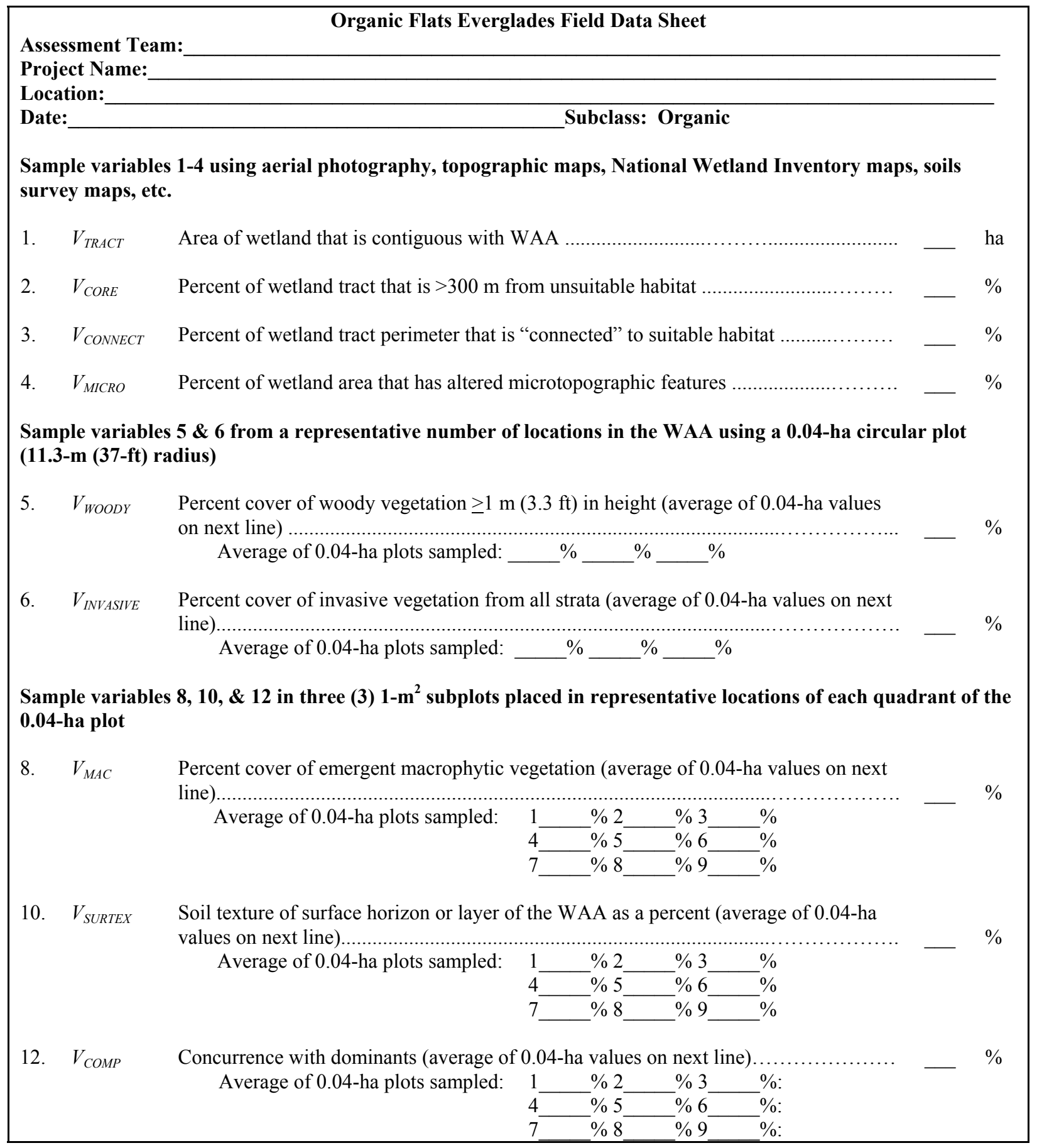

Figure B3. Field Data Sheet for Organic Flats Everglades Wetlands 


\section{Appendix C Supplementary Information on Model Variables}

This appendix contains the following summaries:

a. Soil Texture by Feel - page C2

b. Percent cover - page $\mathrm{C} 3$

c. Species list - page C4

d. Dominant Species Photographs - page C10 


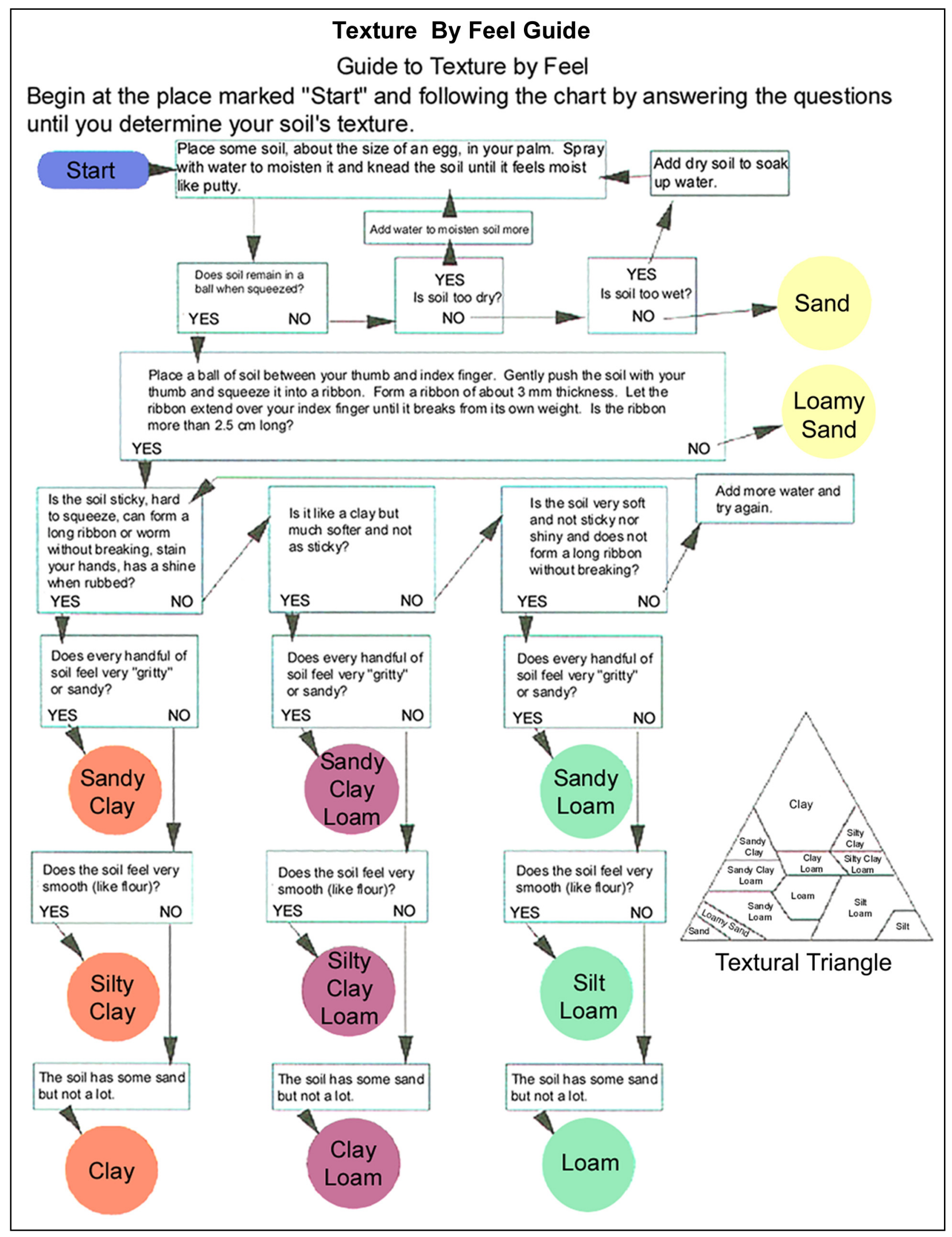

Figure $\mathrm{C} 1$. Soil texture by feel 


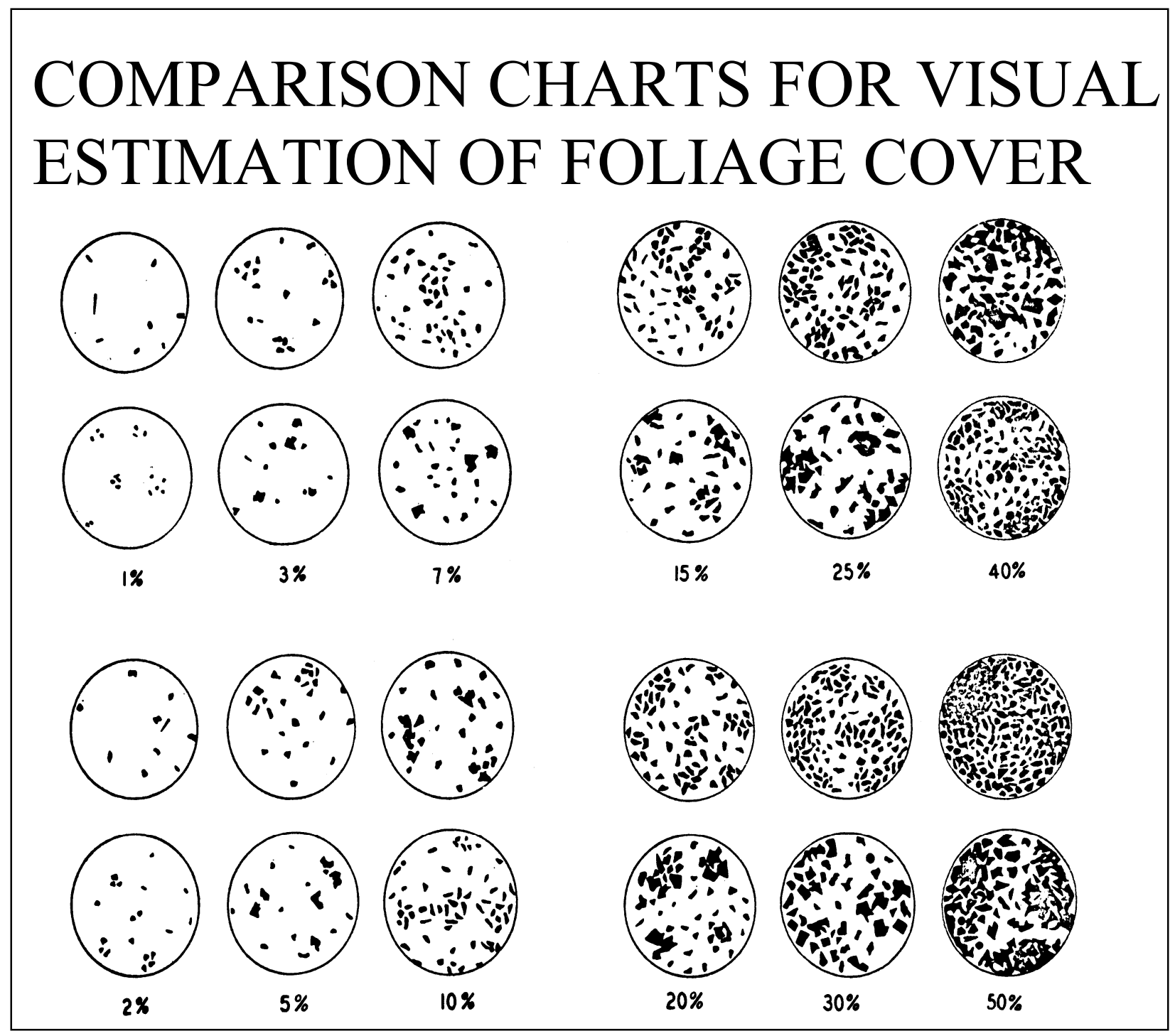

Figure C2. Percent cover (Developed by Richard D. Terry and George V. Chilingar. Published by the Society of Economic Paleontologists in its Journal of Sedimentary Petrology 25(3), 229-234, September 1955) 


\begin{tabular}{|c|c|}
\hline \multicolumn{2}{|c|}{$\begin{array}{l}\text { Table C1 } \\
\text { Species List Found During Data Collection for All Subclasses }\end{array}$} \\
\hline Scientific Name & Common Name \\
\hline Acrostichum danaeifolium & Inland leatherfern \\
\hline Aeschynomene pratensis & Meadow jointvetch \\
\hline Agalinis linifolia & Flaxleaf false foxglove \\
\hline Agalinis maritima & Saltmarsh false foxglove \\
\hline Agalinis purpurea & Purple false foxglove \\
\hline Aletris farinosa & White colicroot \\
\hline Aletris lutea & Yellow colicroot \\
\hline Amaranthus australis & Southern amaranth \\
\hline Amaranthus spinosus & Spiny amaranth \\
\hline Ambrosia artemisiifolia & Annual ragweed \\
\hline Ammania coccinea & Valley redstem \\
\hline Ammania latifolia & Pink redstem \\
\hline Ampelopsis arborea & Peppervine \\
\hline Amphicarpum muhlenbergianum & Muhlenberg maiden cane \\
\hline Andropogon glomeratus & Bushy bluestem \\
\hline Andropogon virginicus & Broomsedge bluestem \\
\hline Anemia adiantifolia & Pineland fern \\
\hline Angadenia berteroi & Pineland golden trumpet \\
\hline Annona glabra & Pond apple \\
\hline Ardisia elliptica & Shoebutton \\
\hline Aristida palustris & Longleaf threeawn \\
\hline Aristida virgata & Arrowfeather threeawn \\
\hline Asclepias incarnata & Swamp milkweed \\
\hline Asclepias lanceolata & Fewflower milkweed \\
\hline Axonopus affinis & Common carpetgrass \\
\hline Baccharis glomeruliflora & Silverling \\
\hline Baccharis halimifolia & Eastern baccharis \\
\hline Bacopa caroliniana & Blue waterhyssop \\
\hline Bacopa monnieri & Herb of grace \\
\hline Berchemia scandens & Alabama supplejack \\
\hline Bidens alba & Romerillo \\
\hline Bidens pilosa & Hairy beggartick \\
\hline Bigelowia nudata & Pineland rayless goldenrod \\
\hline Blechnum serrulatum & Toothed midsorus fern \\
\hline Boehmeria cylindrica & Smallspike false nettle \\
\hline Buchnera americana & American bluehearts \\
\hline Bursera simaruba & Gumbo limbo \\
\hline Callicarpa americana & American beautyberry \\
\hline Caperonia palustris & Sacatrapo \\
\hline Cassytha filiformis & Devil's gut \\
\hline Casuarina equisetifolia & Australian pine \\
\hline Celtis laevigata & Sugarberry \\
\hline Centella asiatica & Spadeleaf \\
\hline Cephalanthus occidentalis & Common buttonbush \\
\hline Chamaesyce hyssopifolia & Hyssopleaf sandmat \\
\hline Chiococca alba & West indian milkberry \\
\hline Cirsium nuttallii & Nuttall's thistle \\
\hline Cissus verticilla & Seasonvine \\
\hline Cladium colocasia & Malanga \\
\hline Cladium jamaicense & Saw grass \\
\hline Coelorachis rugosa & Wrinkled jointtail grass \\
\hline Colocasia esculenta & Coco yam \\
\hline & (Sheet 1 of 6$)$ \\
\hline
\end{tabular}




\begin{tabular}{|c|c|}
\hline \multicolumn{2}{|c|}{ Table C1 (Continued) } \\
\hline Scientific Name & Common Name \\
\hline Commelina diffusa & Climbing dayflower \\
\hline Conocarpus erectus & Button mangrove \\
\hline Conoclinium coelestinum & Blue mistflower \\
\hline Coreopsis leavenworthii & Leavenworth's tickseed \\
\hline Crinum americanum & Seven sisters \\
\hline Cuphea carthagenesis & Columbian waxweed \\
\hline Cyperus distinctus & Swamp flatsedge \\
\hline Cyperus haspan & Haspan flatsedge \\
\hline Cyperus ochraceus & Pond flatsedge \\
\hline Cyperus odoratus & Fragrant flatsedge \\
\hline Cyperus polystachyos & Manyspike flatsedge \\
\hline Cyperus surinamensis & Tropical flatsedge \\
\hline Dactyloctenium aegyptium & Egyptian grass \\
\hline Descurainia pinnata & Western tansymustard \\
\hline Dichanthelium dichotomum & Cypress panic grass \\
\hline Dichanthelium erectifolium & Erectleaf panic grass \\
\hline Dichanthelium sabulorum & Hemlock rosette grass \\
\hline Dichromena colorata & Starrush whitetop \\
\hline Digitaria violascens & Violet crabgrass \\
\hline Diodia teres & Poorjoe \\
\hline Diodia virginiana & Virginia buttonweed \\
\hline Distichlis spicata & Inland saltgrass \\
\hline Dyschoriste angusta & Pineland snakeherb \\
\hline Echinochloa colona & Jungle rice \\
\hline Eclipta prostrata & False daisy \\
\hline Eleocharis cellulosa & Coastal spikerush \\
\hline Eleocharis elongata & Slim spikerush \\
\hline Eleocharis geniculata & Canada spikerush \\
\hline Eleocharis interstincta & Knotted spikerush \\
\hline Eleusine indica & Indian goosegrass \\
\hline Elytraria caroliniensis & Carolina scalystem \\
\hline Emilia fosbergii & Florida tasselflower \\
\hline Equisetum hyemale & Scouringrush horsetail \\
\hline Eragrostis elliottii & Field lovegrass \\
\hline Eragrostis refracta & Coastal lovegrass \\
\hline Eragrostis tenella & Japanese lovegrass \\
\hline Erechtites hieracifolia & Burnweed \\
\hline Erianthus giganteus & Sugarcane plumgrass \\
\hline Eriocaulon decangulare & Tenangle pipewort \\
\hline Eryngium yuccifolium & Button eryngo \\
\hline Eupatorium capillifolium & Dogfennel \\
\hline Eupatorium leptophyllum & False fennel \\
\hline Eupatorium mikanioides & Semaphore thoroughwort \\
\hline Euphorbia heterophylla & Mexican fireplant \\
\hline Euphorbia polyphylla & Lesser florida spurge \\
\hline Eustachys glauca & Saltmarsh fingergrass \\
\hline Ficus aurea & Strangler fig \\
\hline Ficus citrifolia & Wild banyantree \\
\hline Fimbristylis miliacea & Grasslike fimbry \\
\hline Fimbristylis spathacea & Hurricanegrass \\
\hline Flaveria linearis & Narrowleaf yellowtops \\
\hline Fuirena breviseta & Saltmarsh umbrella-sedge \\
\hline Funastrum clausum & White twinevine \\
\hline
\end{tabular}




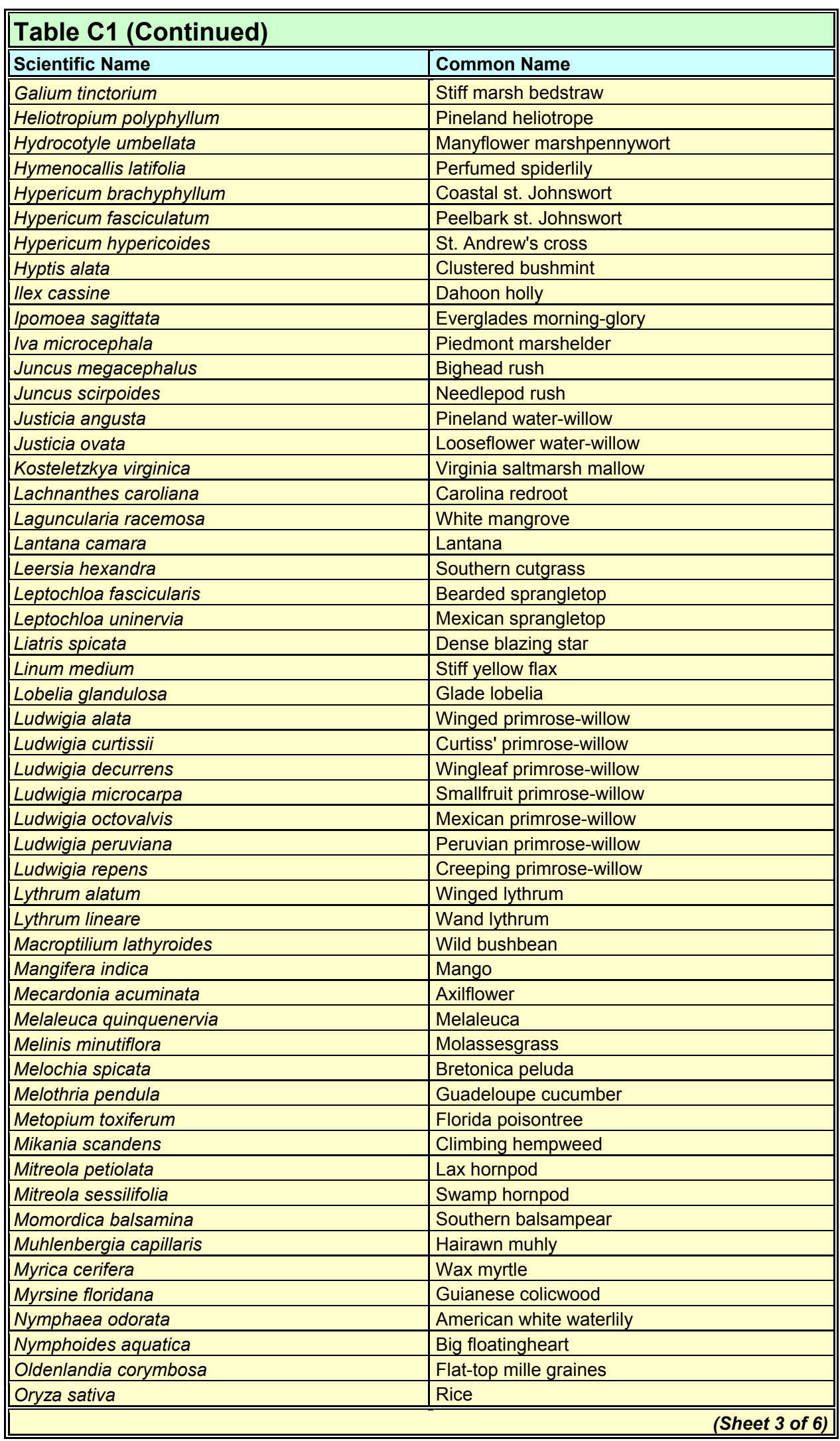




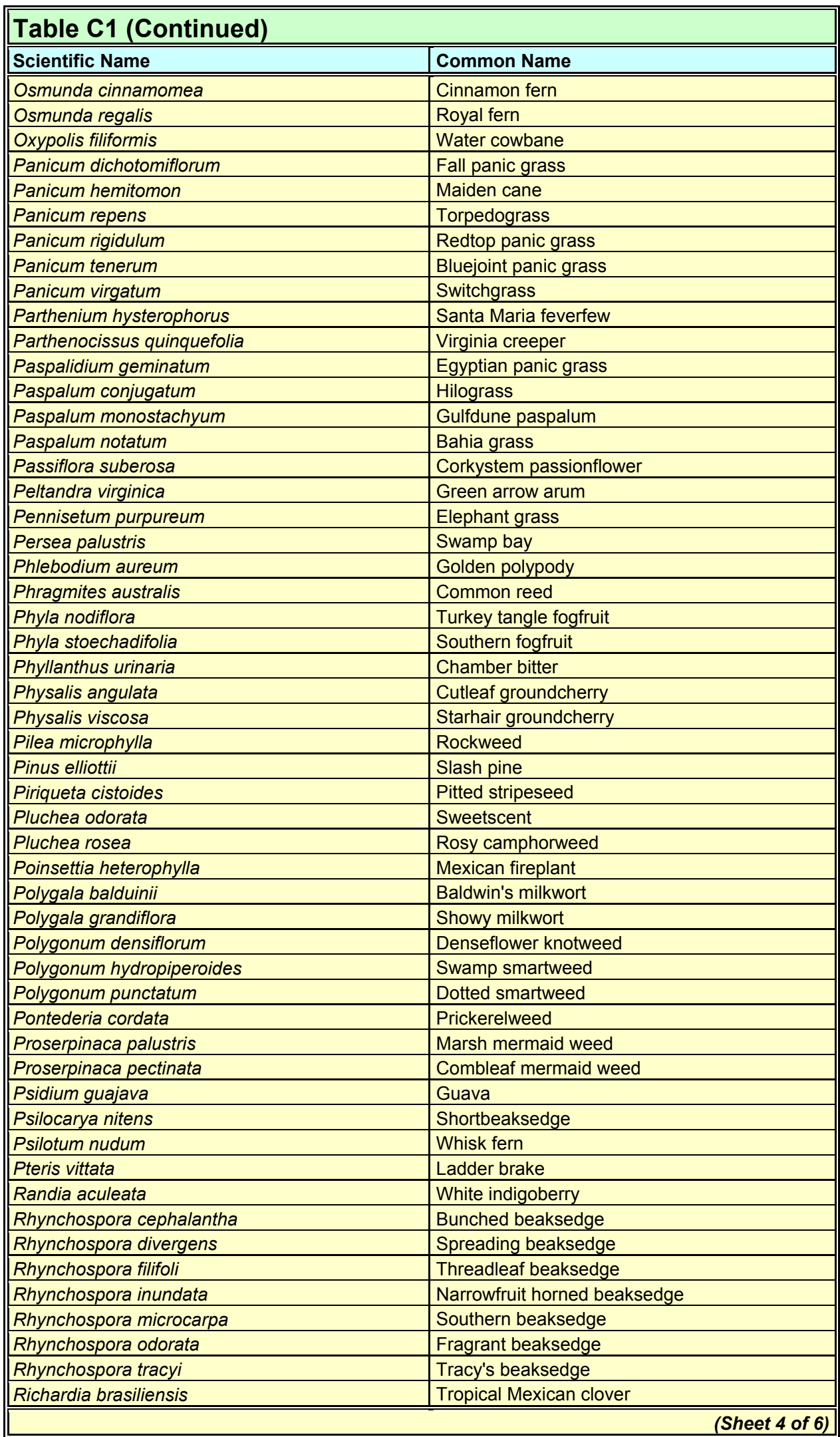




\begin{tabular}{|c|c|}
\hline \multicolumn{2}{|l|}{ Table C1 (Continued) } \\
\hline Scientific Name & Common Name \\
\hline Roystonea elata & Florida royal palm \\
\hline Sabal palmetto & Cabbage palmetto \\
\hline Sabatia grandiflora & Largeflower rose gentia \\
\hline Saccharum giganteum & Sugarcane plumegrass \\
\hline Saccharum officinarum & Sugarcane \\
\hline Sacciolepis striata & American cupscale \\
\hline Sagittaria graminea & Grassy arrowhead \\
\hline Sagittaria lancifolia & Bulltongue arrowhead \\
\hline Salix caroliniana & Coastal plain willow \\
\hline Sambucus canadensis & Common elderberry \\
\hline Samolus ebracteatus & Limewater brookweed \\
\hline Schinus terebinthifolius & Brazilian peppertree \\
\hline Schizachyrium rhizomatum & Florida little bluestem \\
\hline Schoenoplectus tabernaemontani & Softstem bulrush \\
\hline Scleria reticularis & Netted nutrush \\
\hline Scleria verticillata & \begin{tabular}{|l|} 
Low nutrush \\
\end{tabular} \\
\hline Sesbania exalta & Bigpod sesbania \\
\hline Setaria parviflora & Marsh bristlegrass \\
\hline Sida antillensis & Antilles fanpetals \\
\hline Sisyrinchium atlanticum & Eastern blue-eyed grass \\
\hline Solanum donianum & Mullein nightshade \\
\hline Solidago fistulosa & Pinebarren goldenrod \\
\hline Solidago gigantea & Giant goldenrod \\
\hline Solidago sempervirens & Seaside goldenrod \\
\hline Solidago stricta & Wand goldenrod \\
\hline Sorghum halepense & Johnsongrass \\
\hline Spartina alterniflora & Smooth cordgrass \\
\hline Spartina bakeri & Sand cordgrass \\
\hline Spermacoce assurgens & Woodland false buttonweed \\
\hline Spermacoce verticillata & Shrubby false buttonweed \\
\hline Sporobolus indicus & Smut grass \\
\hline Stenandrium floridanum & Sweet shaggytuft \\
\hline Stillingia aquatica & Water toothleaf \\
\hline Symphyotrichum divaricatum & Southern annual saltmarsh aster \\
\hline Symphyotrichum subulatum & Eastern annual saltmarsh aster \\
\hline Taxodium distichum & Bald cypress \\
\hline Teucrium canadense & Canada germander \\
\hline Thalia geniculata & Bent alligator-flag \\
\hline Thelypteris hispidula & Roughhairy maiden fern \\
\hline Thelypteris kunthii & Kunth's maiden fern \\
\hline Thelypteris noveboracensis & New york fern \\
\hline Toxicodendron radicans & Eastern poison ivy \\
\hline Trema micranthum & Jamaican nettletree \\
\hline Triadenum virginicum & Virginia marsh st. Johnswort \\
\hline Tripsacum dactyloides & Eastern gamagrass \\
\hline Typha domingensis & Southern cattail \\
\hline Urena lobata & Caesarweed \\
\hline Utricularia biflora & Humped bladderwort \\
\hline Utricularia cornuta & Horned bladderwort \\
\hline Utricularia foliosa & Leafy bladderwort \\
\hline Utricularia purpurea & Eastern purple bladderwort \\
\hline Verbena scabra & Sandpaper vervain \\
\hline Viola lanceolata & Bog white violet \\
\hline & (Sheet 5 of 6 ) \\
\hline
\end{tabular}


Table C1 (Concluded)

Scientific Name

Common Name

\begin{tabular}{|l|l}
\hline \hline Vitis aestivalis & Summer grape \\
\hline Vitis rotundifolia
\end{tabular}

Vitis rotundifolia

Muscadine

Woodwardia virginica

Virginia chainfern

(Sheet 6 of 6 ) 


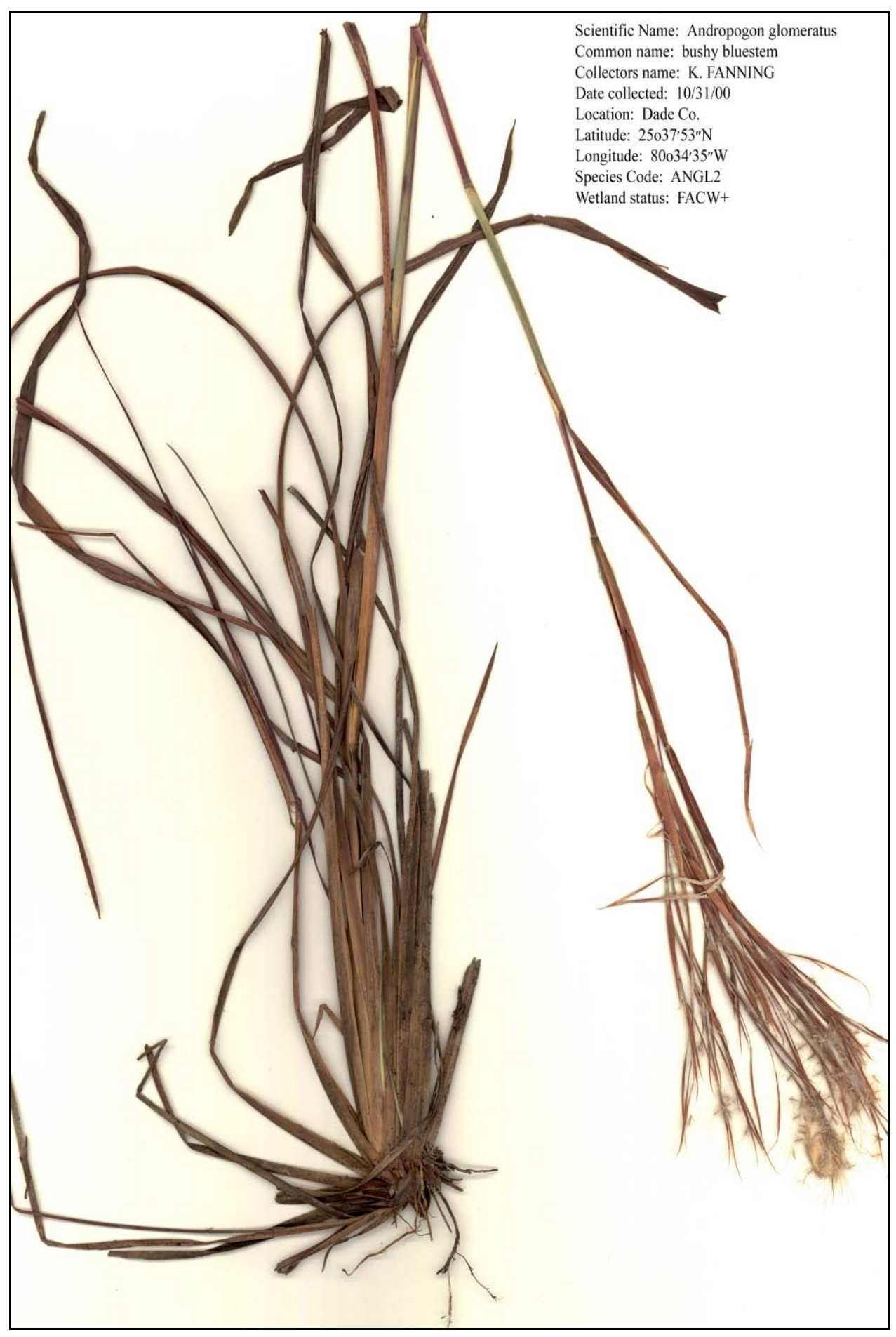

Figure C1. Andropogon glomeratus (bushy bluestem) 


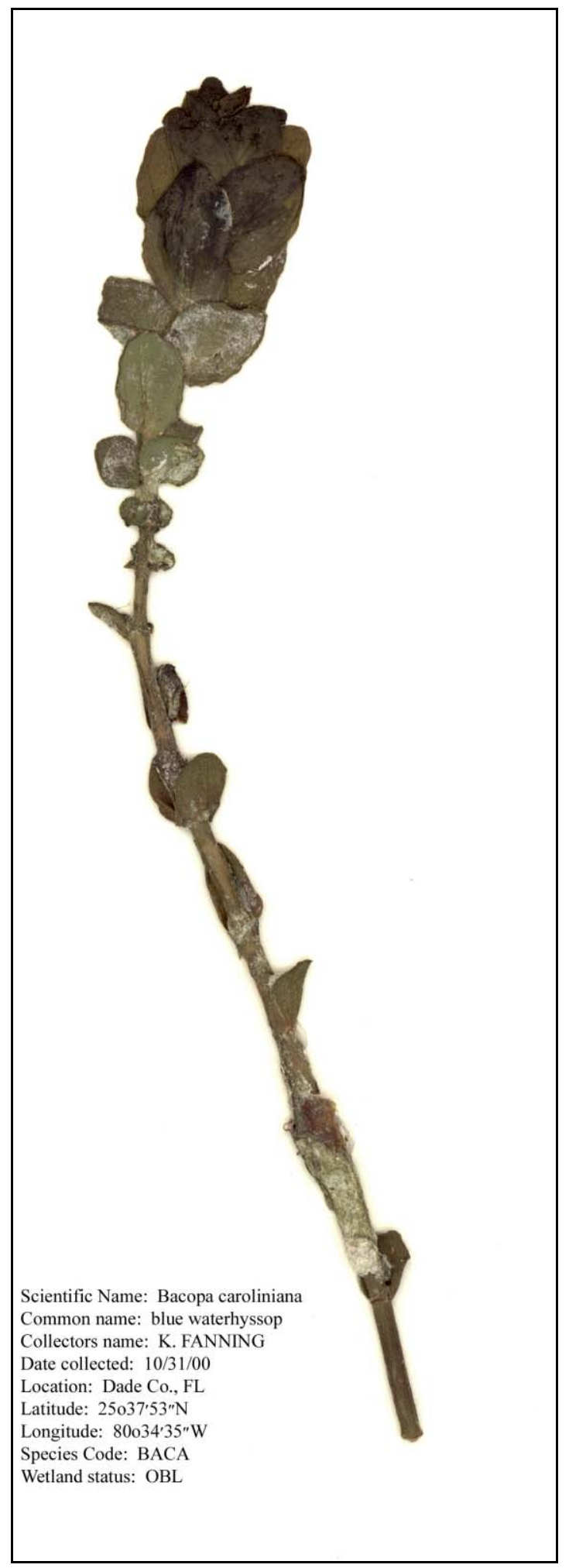

Figure C2. Bacopa caroliniana (blue waterhyssop) 


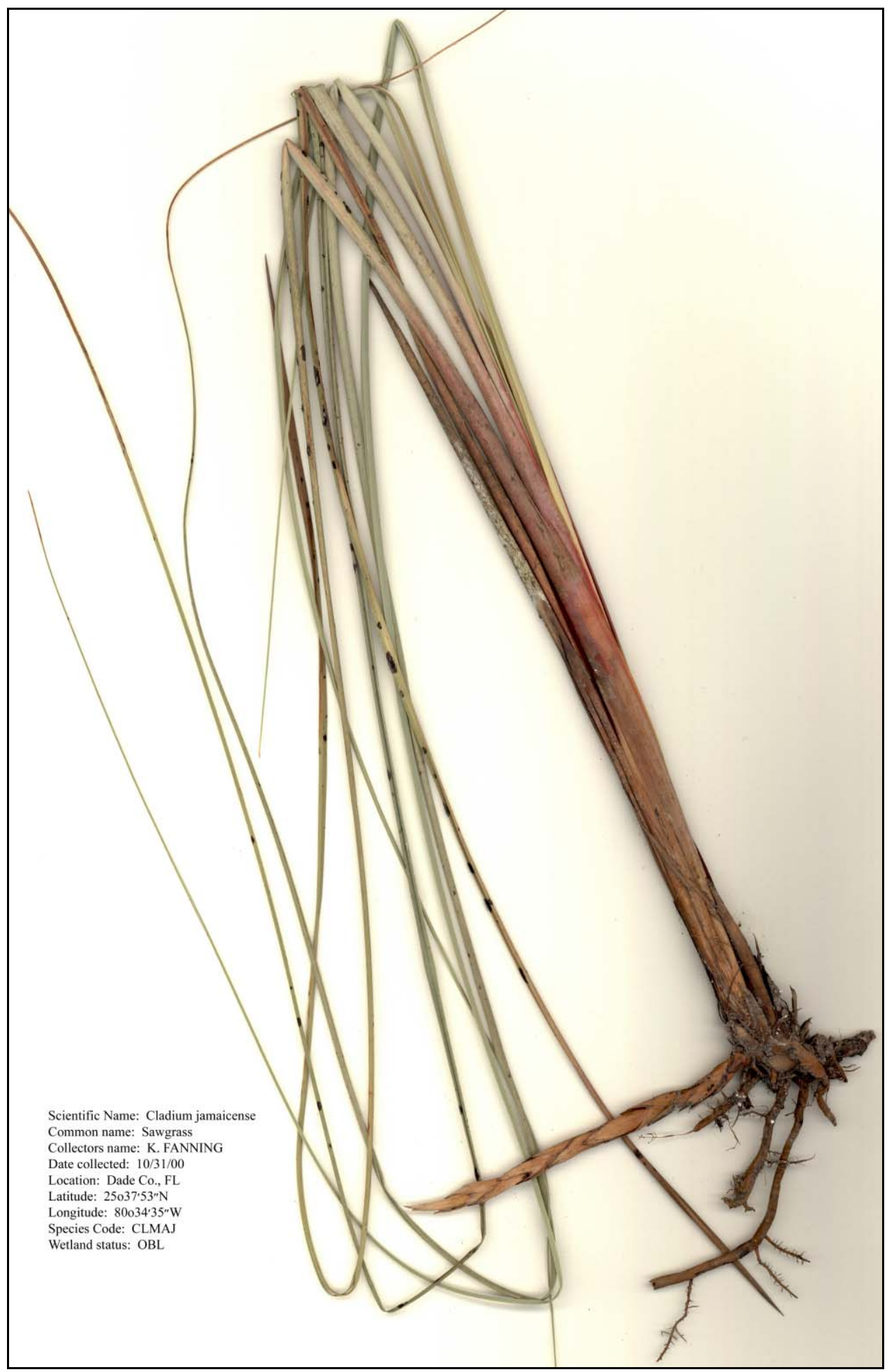

Figure C3. Cladium jamaicense (saw grass) 


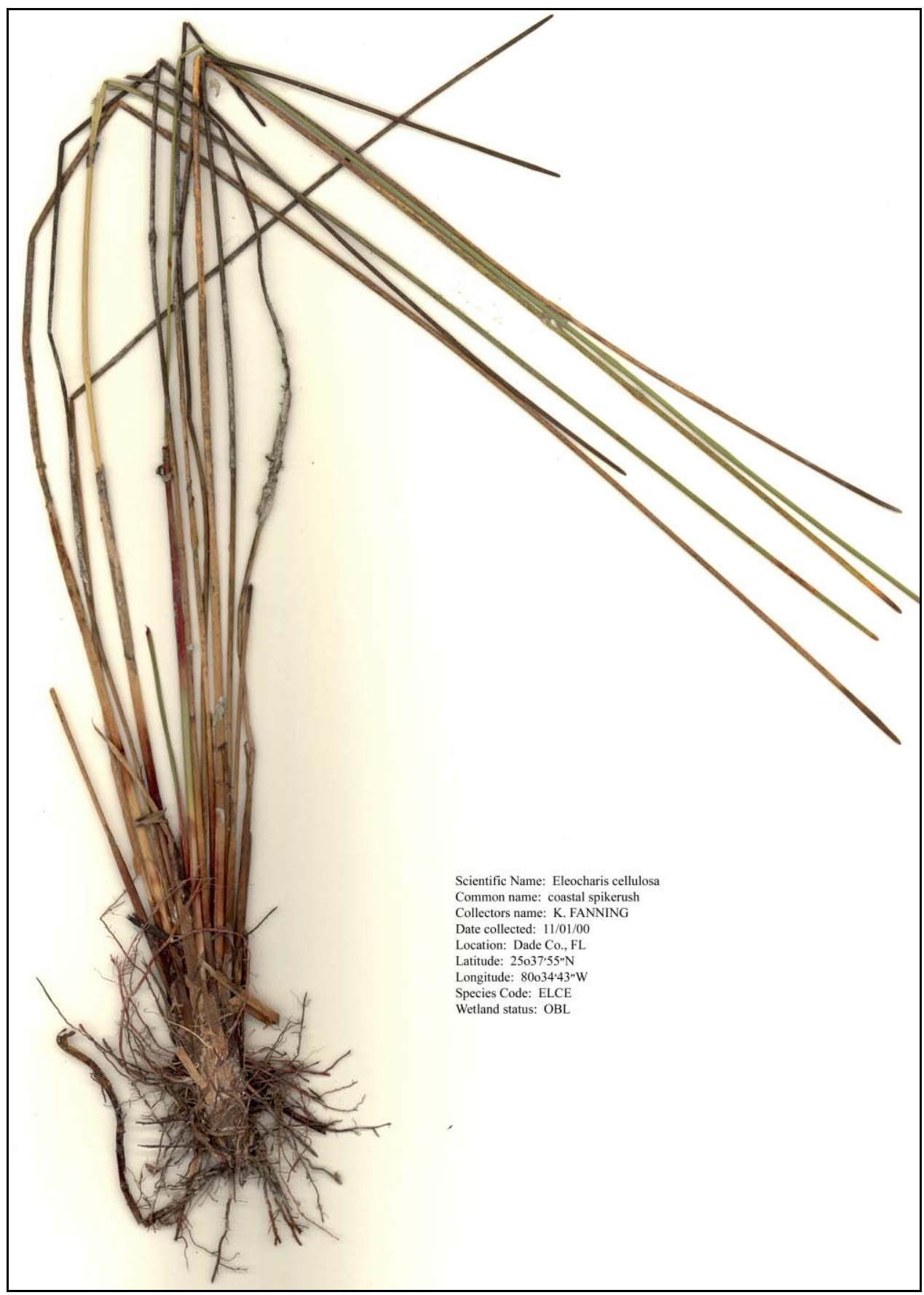

Figure C4. Eleocharis cellulosa (coastal spikerush) 


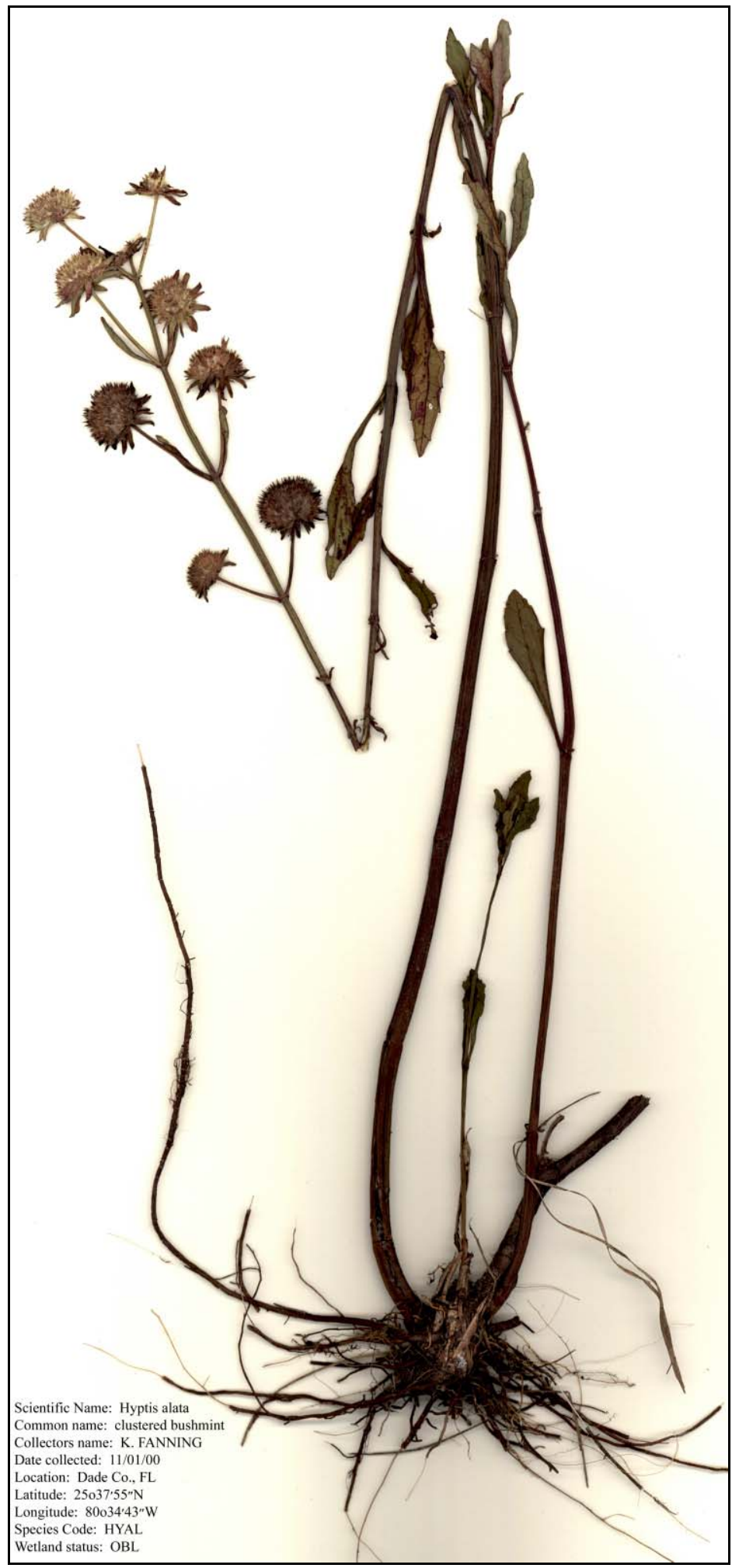

Figure C5. Hyptis alata (clustered bushmint) 


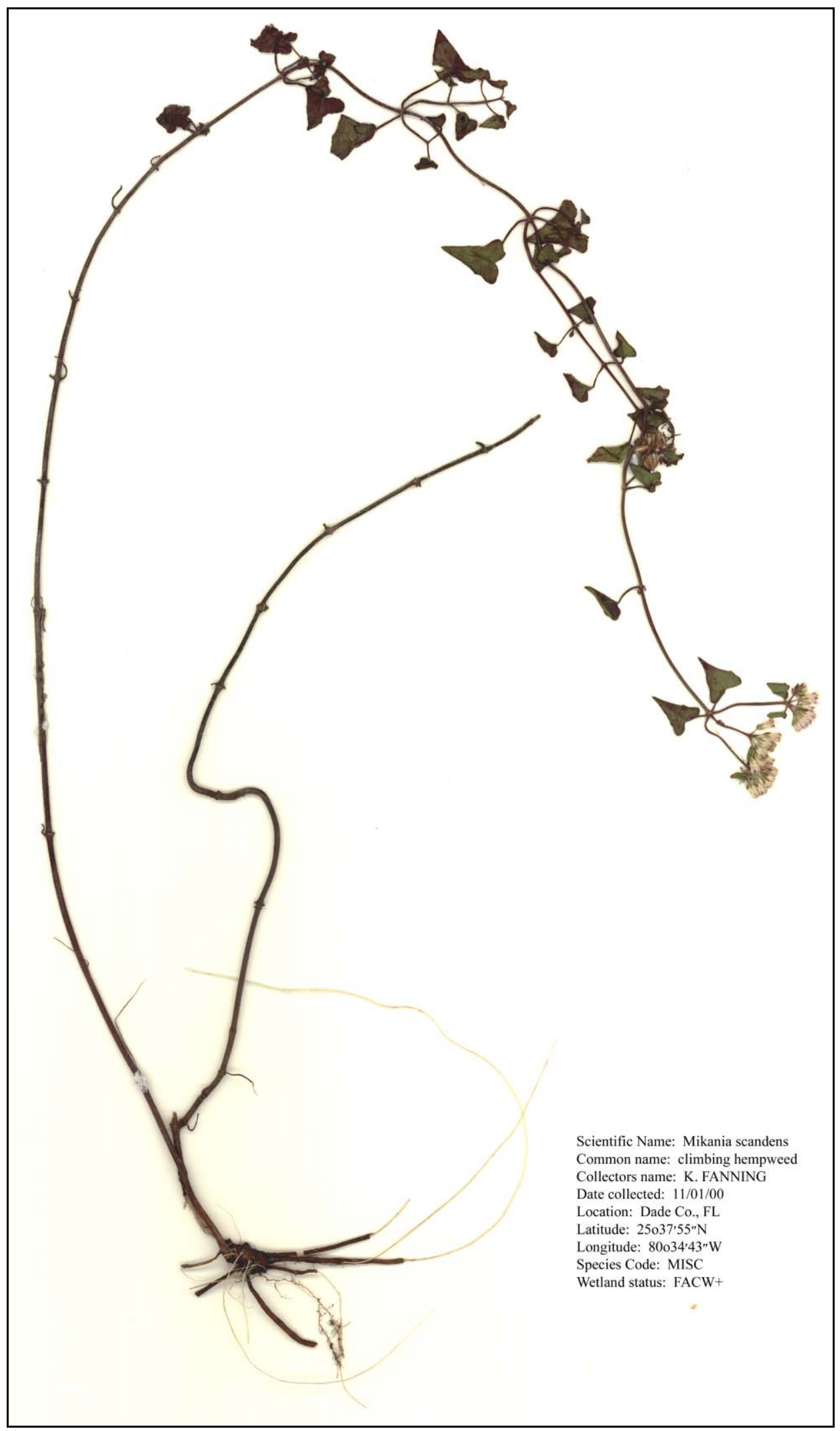

Figure C6. Mikania scandens (climbing hempweed) 


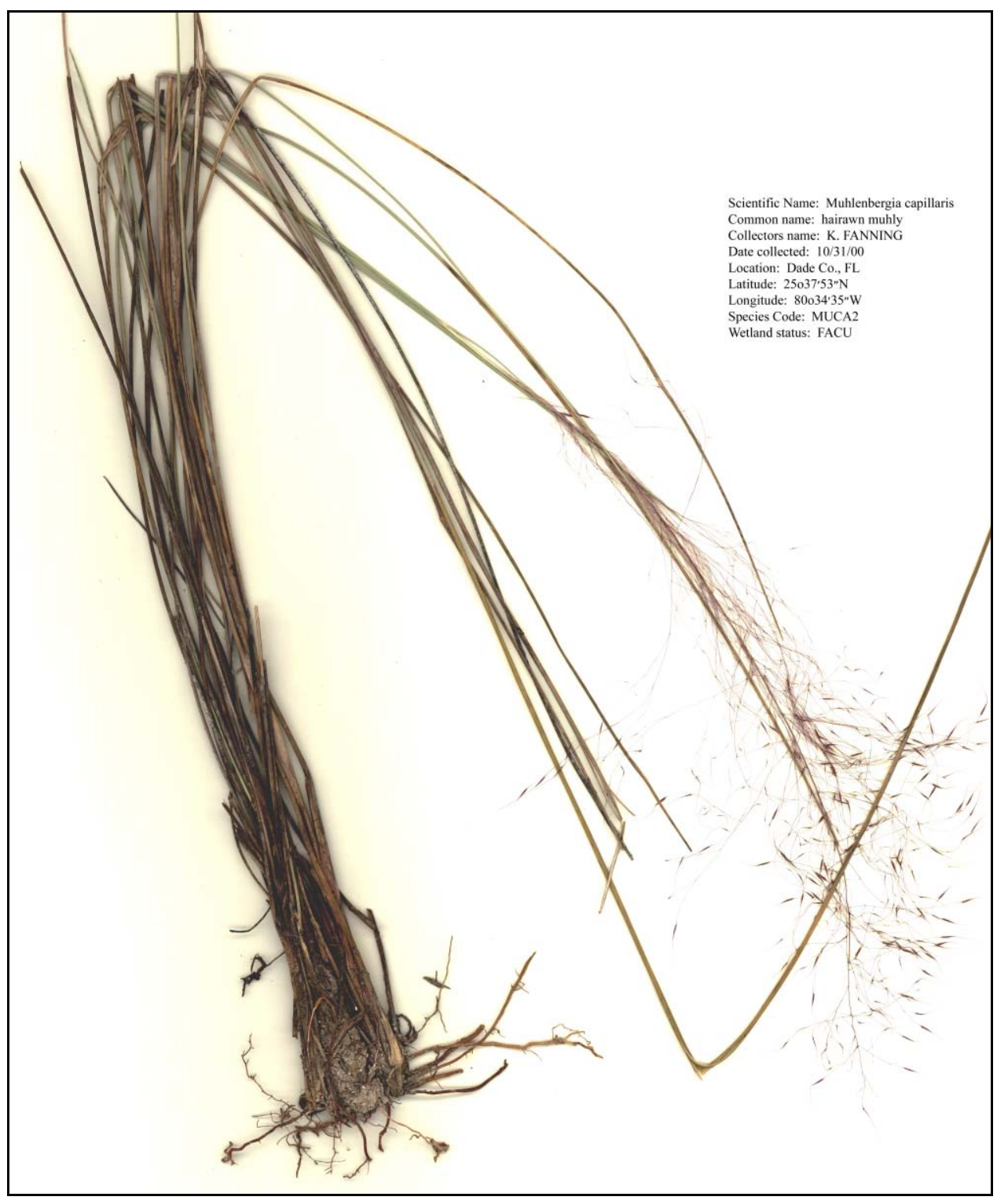

Figure C7. Muhlenbergia capillaries (hairawn muhly) 


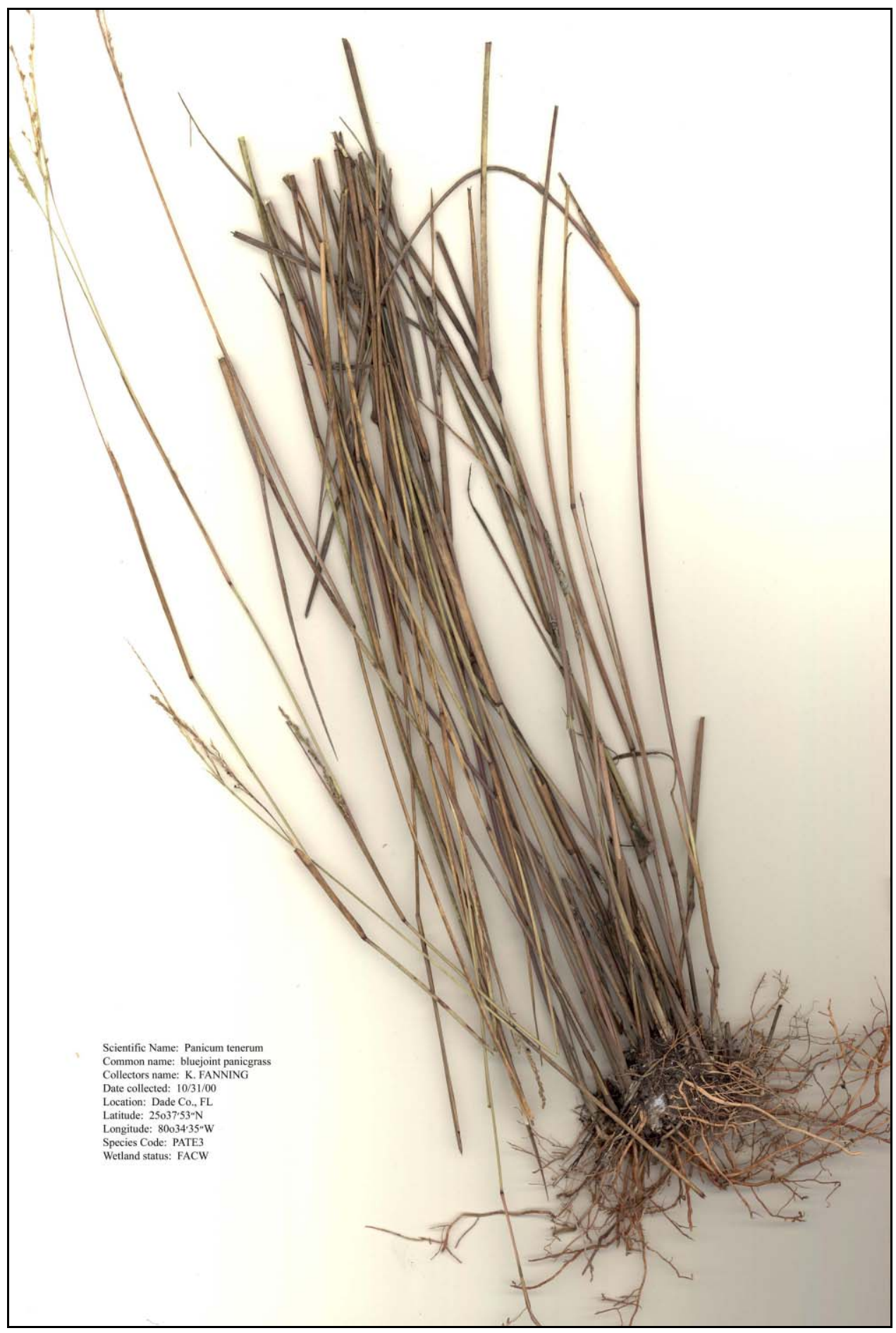

Figure C8. Panicum tenerum (bluejoint panic grass) 


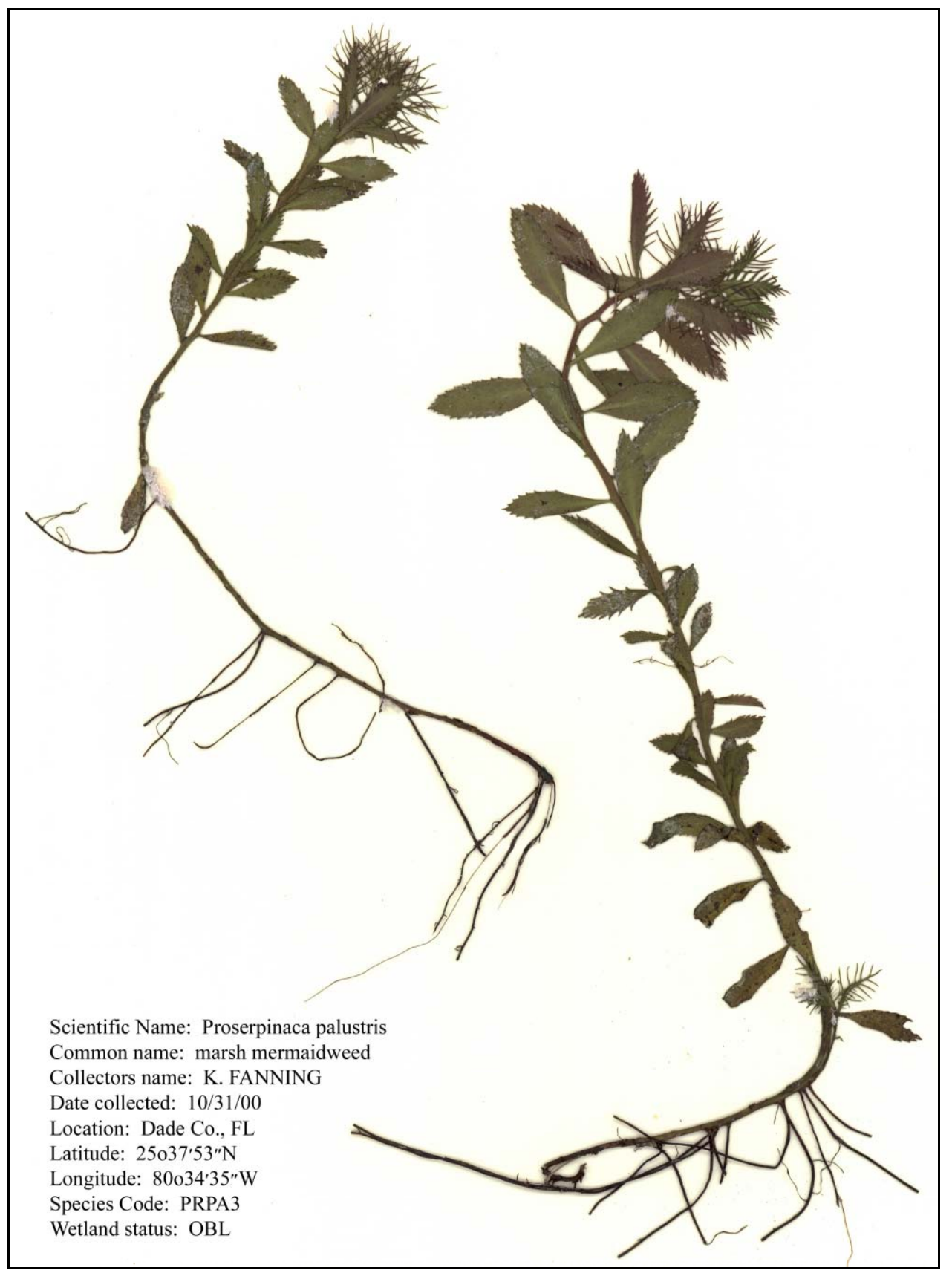

Figure C9. Proserpinaca palustris (marsh mermaid weed) 


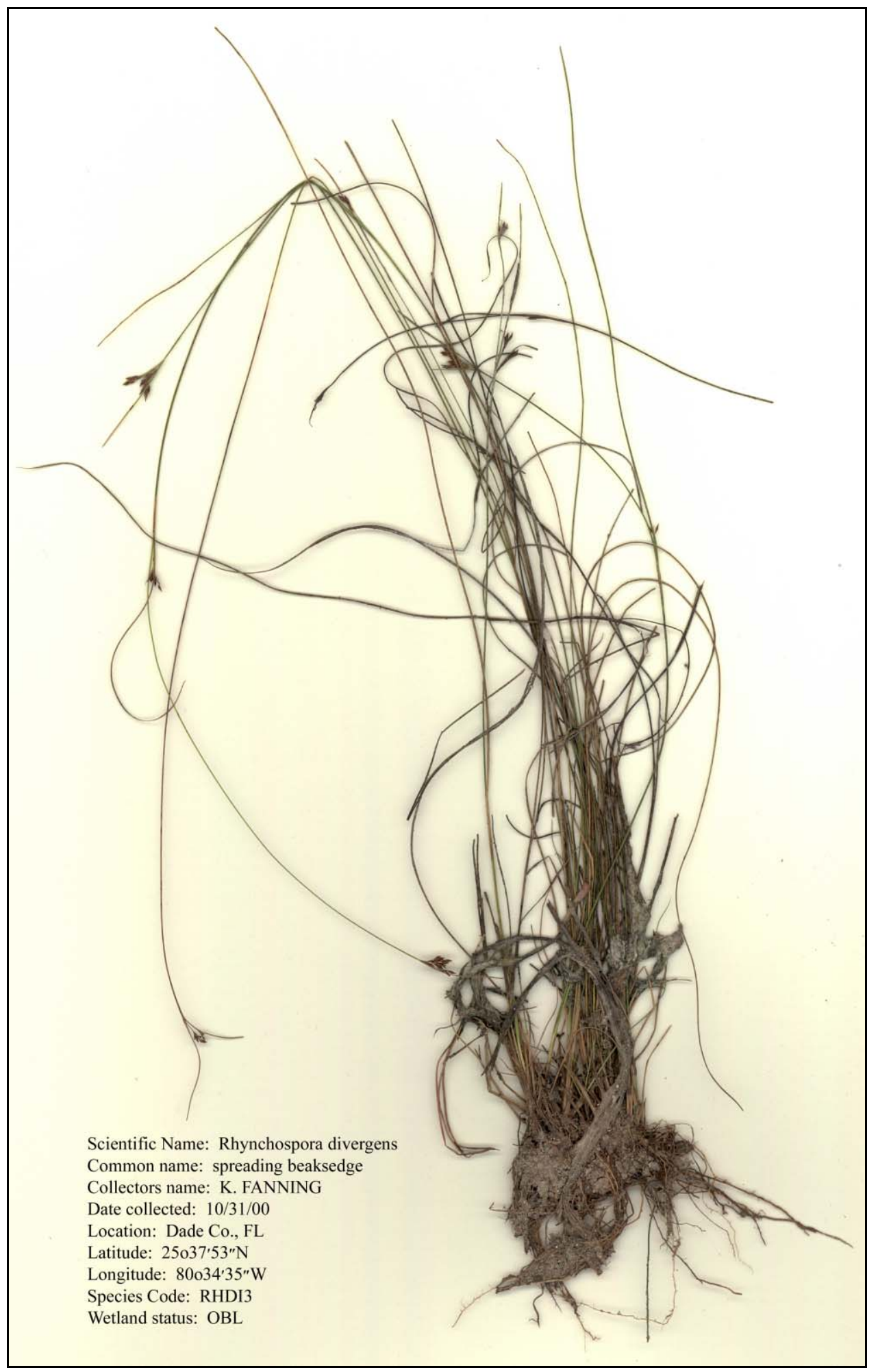

Figure C10. Rhynchospora divergens (spreading beaksedge) 


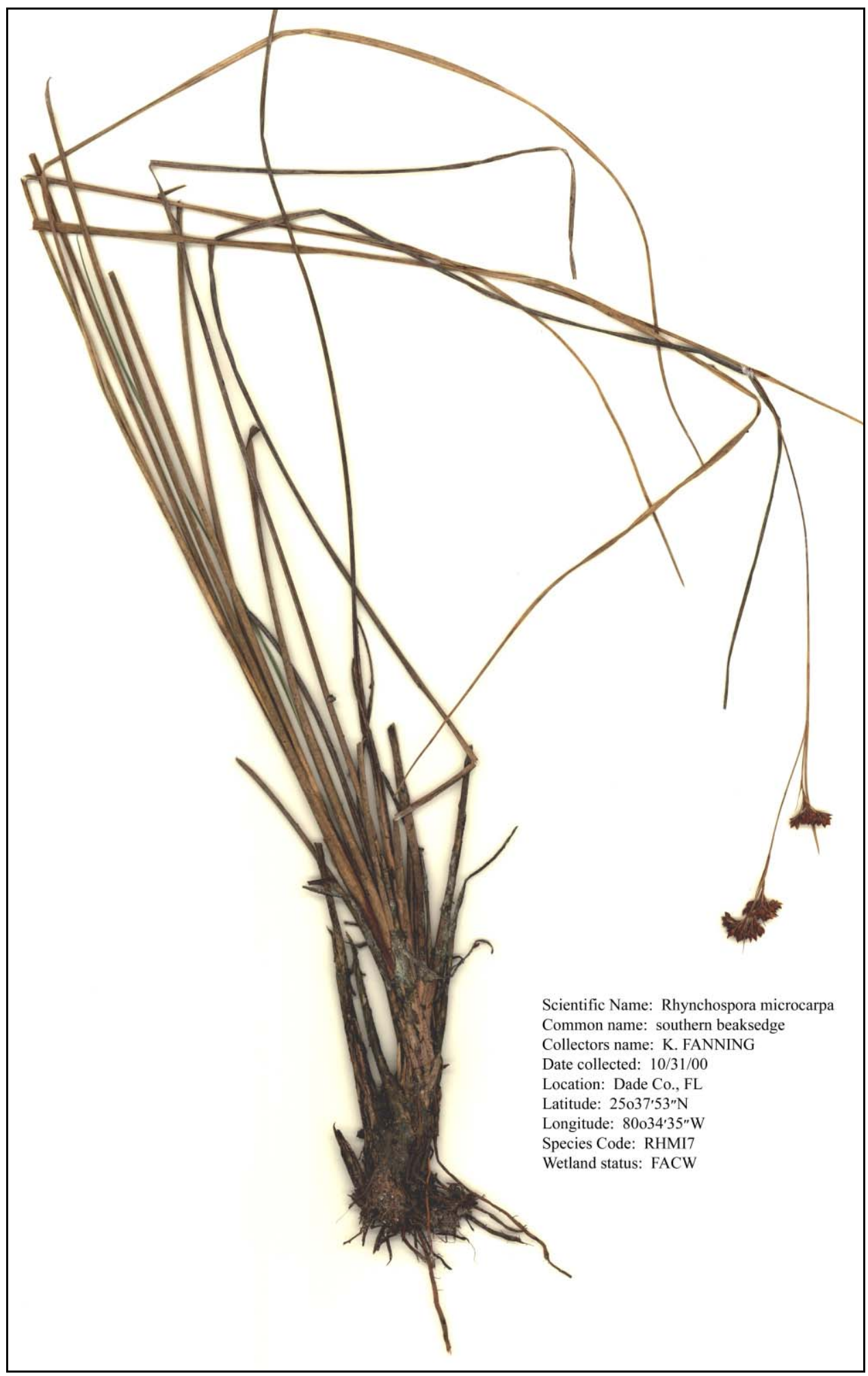

Figure C11. Rhynchospora microcarpa (southern beaksedge) 


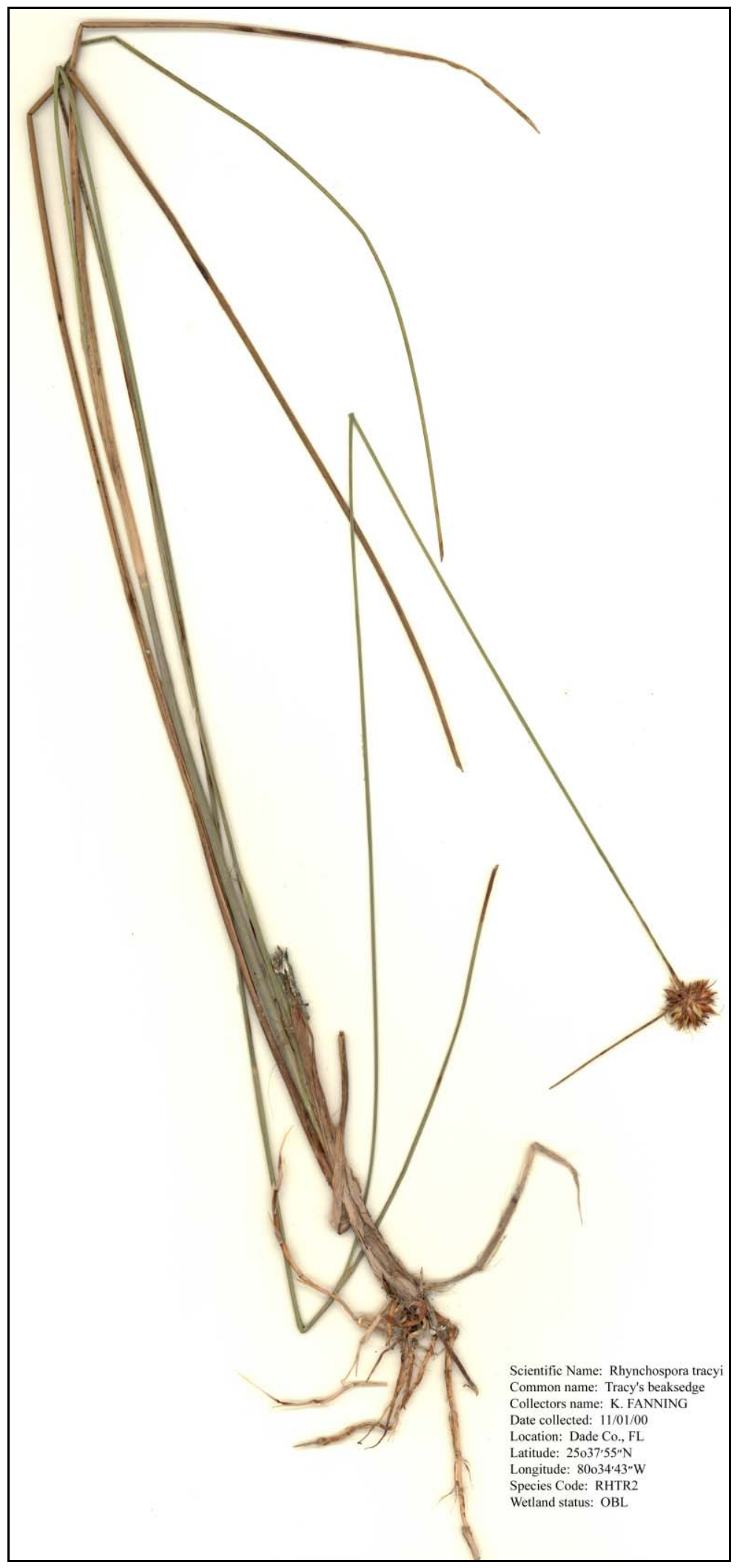

Figure C12. Rhynchospora tracyi (tracy's beaksedge) 


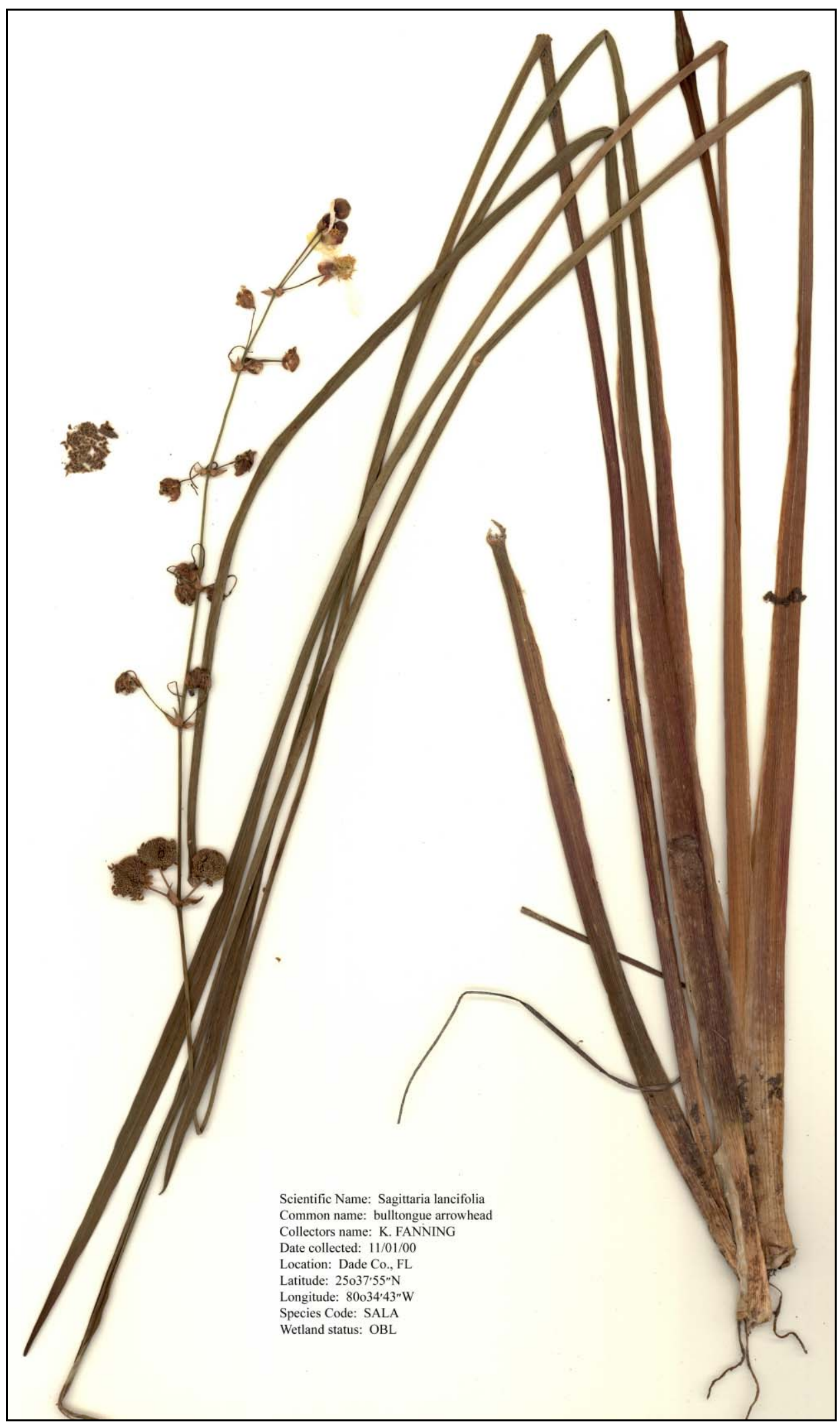

Figure C13. Sagittaria lancifolia (bulltongue arrowhead) 


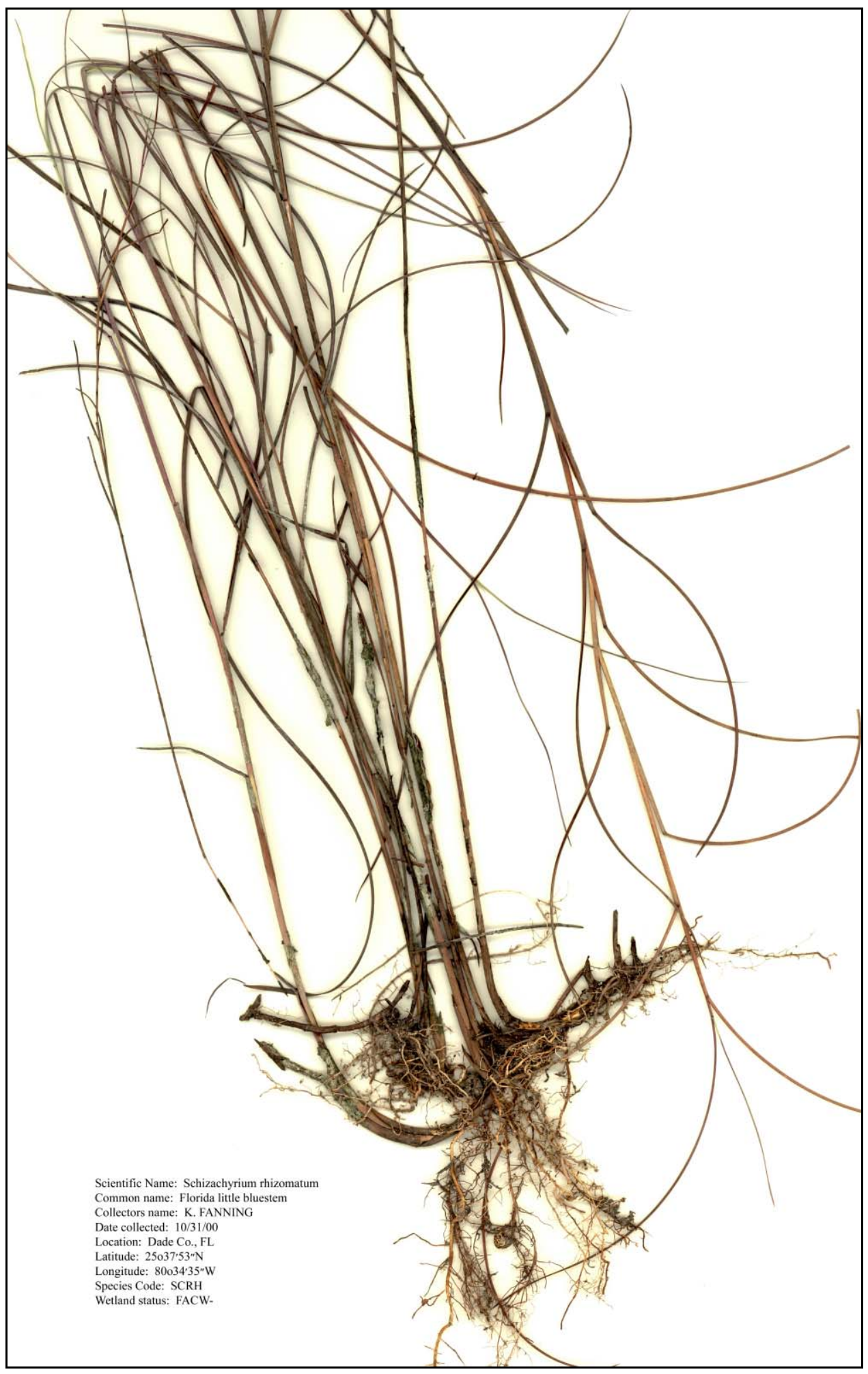

Figure C14. Schizachyrium rhizomatum (Florida little bluestem) 


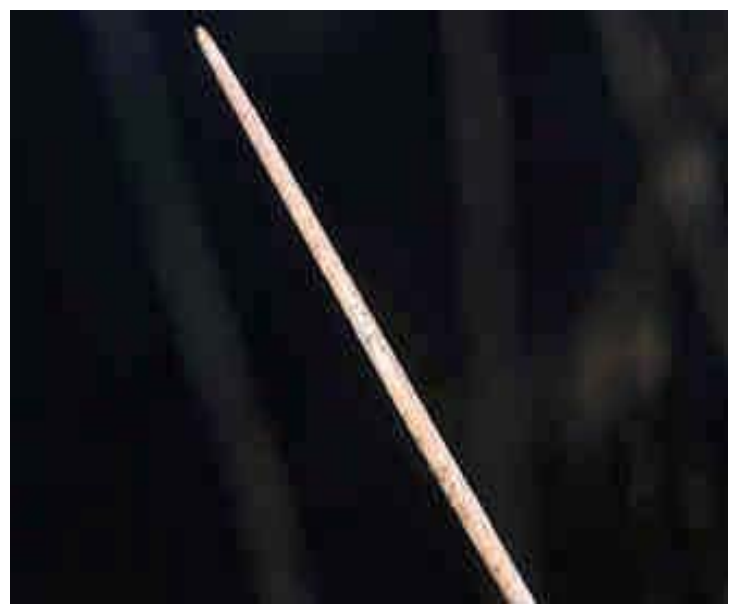

Figure C15. Eleocharis elongata (slim spikerush)

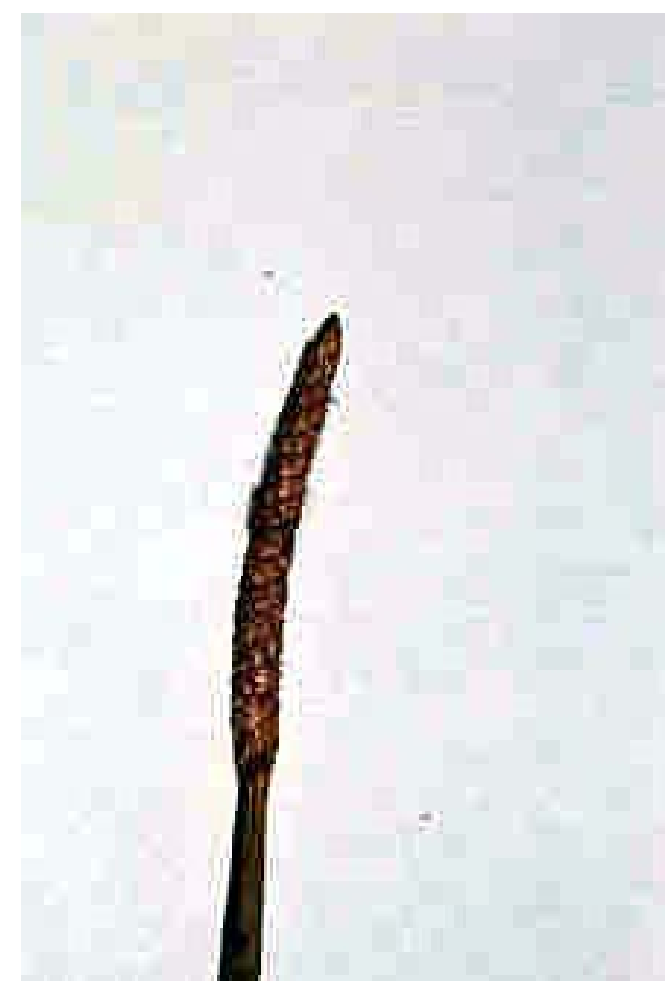

Figure C16. Eleocharis elongata (slim spikerush)

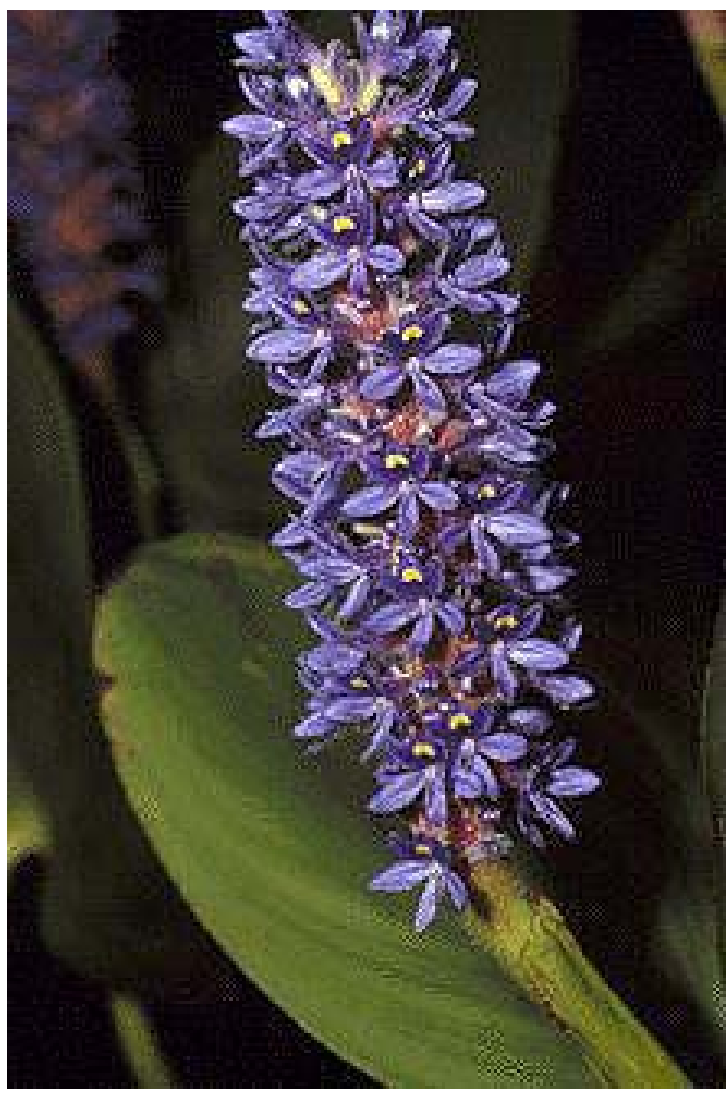

Figure C17. Pontederia cordata (pickerelweed)

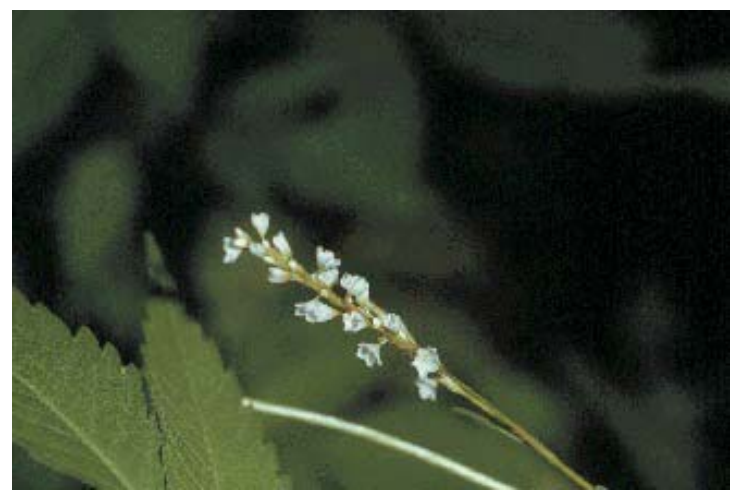

Figure C18. Polygonum hydropiperdoides (swamp smartweed) 


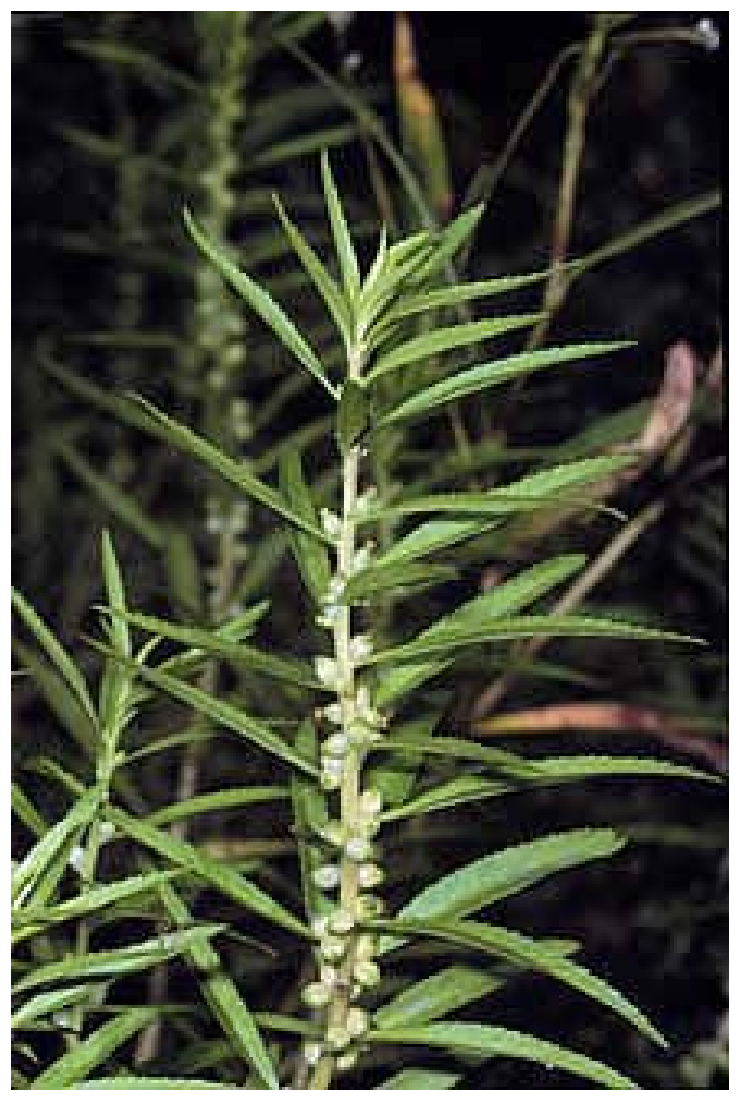

Figure C19. Proserpinaca palustris (marsh mermaidweed)

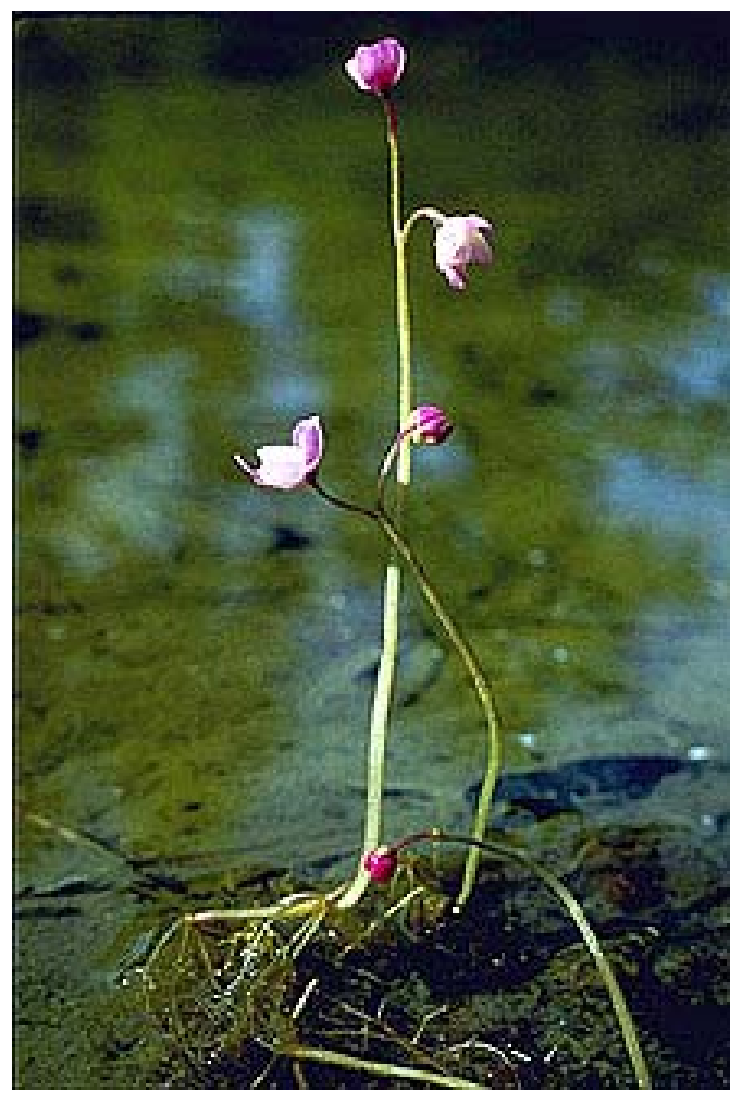

Figure C20. Utricularia purpurea (eastern purple blaterwort) 


\section{Appendix D Reference Wetland Data}

Table D1. Data Collected at Reference Wetland Sites in Everglades Rocky Flats Wetlands ........................................................................ D2

Table D2. Data Collected at Reference Wetland Sites in Everglades Marl Flats Wetlands...................................................................... 3

Table D3. Data Collected at Reference Wetland Sites in Everglades Organic Flats Wetlands ..............................................................D4 







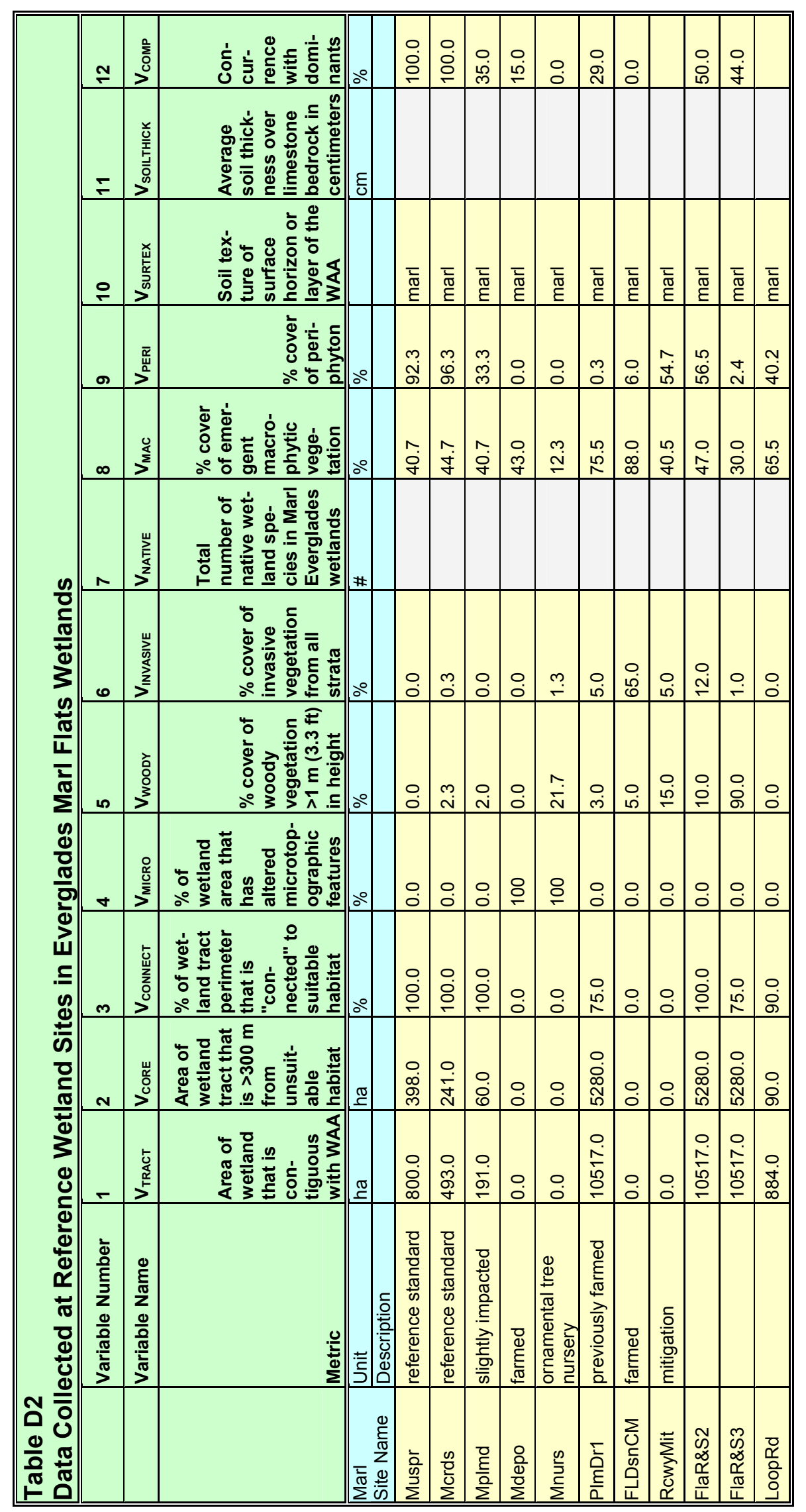




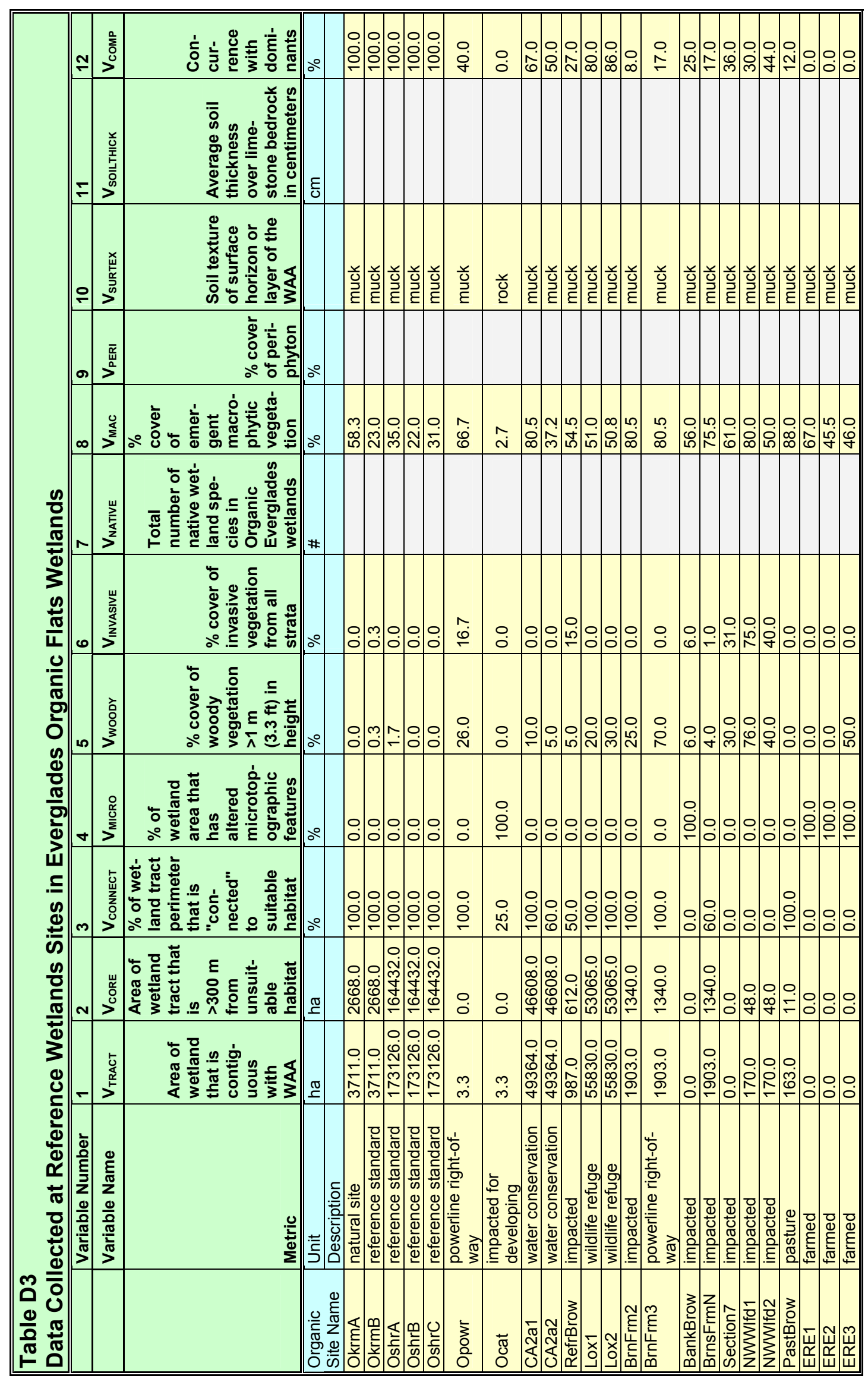




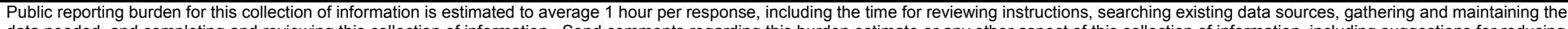

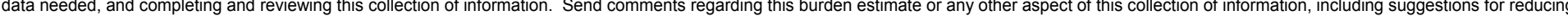

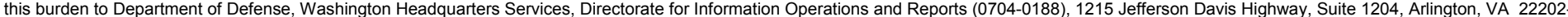

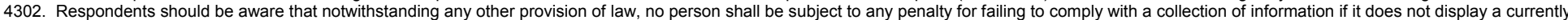
valid OMB control number. PLEASE DO NOT RETURN YOUR FORM TO THE ABOVE ADDRESS.

\begin{tabular}{l|l|l} 
1. REPORT DATE (DD-MM-YYYY) & 2. REPORT TYPE & 3. DATES COVERED (FrOm - To)
\end{tabular}

July 2002

Final report

4. TITLE AND SUBTITLE

A Regional Guidebook for Applying the Hydrogeomorphic Approach to Assessing Wetland

Functions of Flats Wetlands in the Everglades

5a. CONTRACT NUMBER

6. AUTHOR(S)

5b. GRANT NUMBER

5c. PROGRAM ELEMENT NUMBER

Chris V. Noble, Rhonda Evans, Marti McGuire,

Katherine Trott, Mary Davis, Ellis J. Clairain, Jr.

5d. PROJECT NUMBER

5e. TASK NUMBER

5f. WORK UNIT NUMBER

32985

7. PERFORMING ORGANIZATION NAME(S) AND ADDRESS(ES)

8. PERFORMING ORGANIZATION REPORT NUMBER

See reverse

ERDC/EL TR-02-19

10. SPONSOR/MONITOR'S ACRONYM(S)

9. SPONSORING / MONITORING AGENCY NAME(S) AND ADDRESS(ES)

(11)

.S. Army Corps of Engineers

Washington, DC 20314-1000

11. SPONSOR/MONITOR'S REPORT NUMBER(S)

\section{DISTRIBUTION / AVAILABILITY STATEMENT}

Approved for public release; distribution is unlimited.

\section{SUPPLEMENTARY NOTES}

\section{ABSTRACT}

The Hydrogeomorphic (HGM) Approach is a method for developing functional indices and the protocols used to apply these indices to the assessment of wetland functions at a site-specific scale. The HGM Approach was initially designed to be used in the context of the Clean Water Act Section 404 Regulatory Program permit review to analyze project alternatives, minimize impacts, assess unavoidable impacts, determine mitigation requirements, and monitor the success of compensatory mitigation. However, a variety of other potential uses have been identified, including the determination of minimal effects under the Food Security Act, design of wetland restoration projects, and management of wetlands.

This report uses the HGM Approach to develop a Regional Guidebook to (a) characterize the Everglades Flats Wetlands in Florida, (b) provide the rationale used to select functions for the marl, rocky, and organic subclasses, (c) provide the rationale used to select model variables and metrics, (d) provide the rationale used to develop assessment models, (e) provide data from reference wetlands and document its use in calibrating model variables and assessment models, and (f) outline the necessary protocols for applying the functional indices to the assessment of wetland functions.

\section{SUBJECT TERMS}

404 Regulatory Program

Assessment

Classification

Clean Water Act

\section{Ecosystem}

Evaluation

Function

Functional profile
Functional assessment

Geomorphology

Hydrogeomorphic (HGM) Approach

Hydrology

(Continued)

\begin{tabular}{|c|c|c|c|c|c|}
\hline \multicolumn{3}{|c|}{ 16. SECURITY CLASSIFICATION OF: } & \multirow{2}{*}{$\begin{array}{l}\text { 17. LIMITATION } \\
\text { OF ABSTRACT }\end{array}$} & \multirow{2}{*}{$\begin{array}{l}\text { 18. NUMBER } \\
\text { OF PAGES }\end{array}$} & 19a. NAME OF RESPONSIBLE PERSON \\
\hline $\begin{array}{l}\text { a. REPORT } \\
\text { UNCLASSIFIED }\end{array}$ & $\begin{array}{l}\text { b. ABSTRACT } \\
\text { UNCLASSIFIED }\end{array}$ & $\begin{array}{l}\text { c. THIS PAGE } \\
\text { UNCLASSIFIED }\end{array}$ & & & $\begin{array}{l}\text { 19b. TELEPHONE NUMBER (include area } \\
\text { code) }\end{array}$ \\
\hline
\end{tabular}




\section{7. (Continued)}

U.S. Army Engineer Research and Development Center, Environmental Laboratory, 3909 Halls Ferry Road, Vicksburg, MS 391806199; U.S. Environmental Protection Agency, Sam Nunn Federal Center, 61 Forsyth Street, SW, Atlanta, GA 30303-8960; Florida Department of Environmental Protection, 2600 Blair Stone Road, Tallahassee, FL 32399-2400; Headquarters, U.S. Army Corps of Engineers, 441 G St. NW, Washington, DC 20314-1000; National Wildlife Federation, 1313 West Peachtree, Atlanta, GA 30309.

\section{5. (Concluded)}

Impact analysis

Index

Indicators

Landscape

Method

Mitigation

Model

National Action Plan

Procedure

Reference wetlands

Restoration

Value

Wetland 